\title{
A DIFFERENT SHADE OF PINK: \\ LITERARY THRESHOLDS AND CULTURAL INTERSECTIONS IN ITALIAN CHICK LIT
}

By

Federica Balducci

\begin{abstract}
A thesis
submitted to the Victoria University of Wellington in fulfilment of the requirements for the degree of

Doctor of Philosophy

in Italian
\end{abstract}

Victoria University of Wellington

(2011) 


\begin{abstract}
This thesis investigates the Italian production of chick lit, a particular segment of contemporary women's popular fiction developed in the mid 1990s in Anglophone countries. A worldwide phenomenon born out of Helen Fielding's Bridget Jones 's Diary (1996) and the HBO TV show Sex and the City (1998), chick lit novels portray the professional, emotional and sentimental anxieties of white, middle-class, heterosexual and financially independent women in a witty and humorous tone.

The arrival of chick lit and its successful translation into Italian in the late 1990s has prompted many local writers to engage with the genre, but the growing body of chick lit written in Italian and its place in the cultural and literary landscape have yet to be assessed. This thesis explores recurring themes, narrative strategies and stylistic features deployed in Italian chick lit novels not only against their Anglo-American models, but also in relation to Western popular media culture and the Italian tradition of romanzo rosa, its cultures and practices as well as its legacy. It shows the presence of distinct intertextual patterns in dealing with key generic features, such as the identification with the female protagonist and her journey toward self-empowerment, the relationship with consumerism and popular media culture, and the humorous style. This thesis also assesses the nature of chick lit as both a literary genre and a sociocultural phenomenon across countries and languages through theoretical perspectives of cultural studies and feminist theories on women's popular culture and Western popular postfeminism.
\end{abstract}




\section{ACKNOWLEDGEMENTS}

Writing a thesis is like running a marathon. Not only it is a matter of physical

endurance, but it is also an intellectual challenge, and my heartfelt thankfulness goes to the people who have supported me in completing this demanding task.

My supervisor Dr Claudia Bernardi has provided invaluable guidance through the dark alleyways of the writing process, helping me to grow as a scholar as much as a person. Working under Dr Bernardi's supervision has been a great pleasure, and without her advice and commitment this thesis would not have been possible. I am also very grateful to my second supervisor Dr Sally Hill for her insightful feedback and for her assistance, particularly in the final stages of the submission. Dr Hill's enthusiasm and dedication have contributed a great deal to the successful completion of my work.

This thesis is also dedicated to the people who, over the past years, have helped me in many different ways: my extended family in Bologna, Italy; the staff and fellow postgraduate students at Victoria University of Wellington; and of course Yuri, who is always by my side (often against all odds).

Finally, the dogs at Wellington SPCA have provided solace and comic relief when I needed them the most, teaching me how to live in the moment and making this long journey all the more worthwhile. 


\section{CONTENTS}

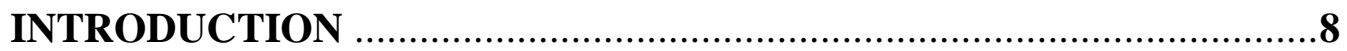

\section{CHAPTER 1}

Chick lit: themes, features and critical assessment.............................22

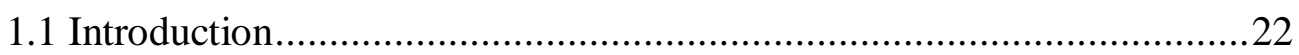

1.2 Chick lit and postfeminist popular culture .......................................22

1.3 Popular fiction genres and intertextuality as a cultural practice ............27

1.4 Chick lit in the marketplace: from Bridget Jones (1996) to Red Dress Ink (2001) .............................................................. 31

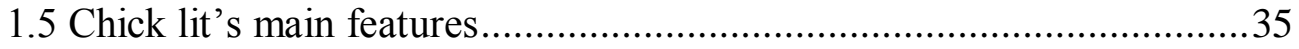

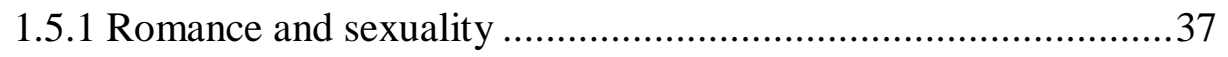

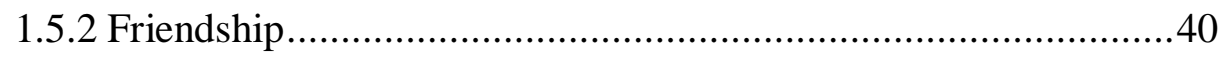

1.5.3 The urban context: locations and professions ..........................43

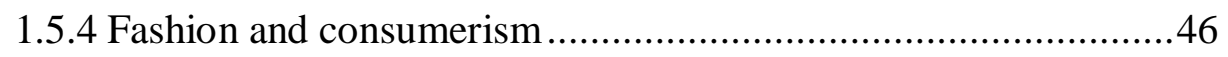

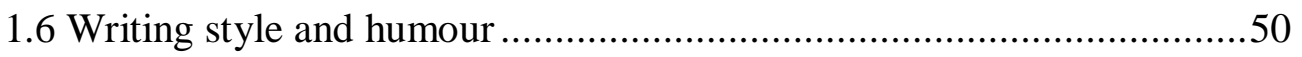

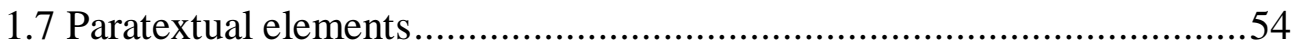

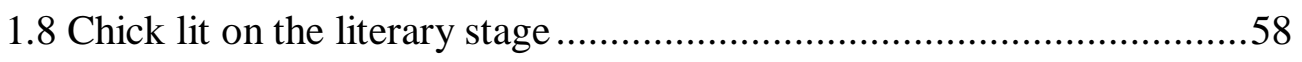

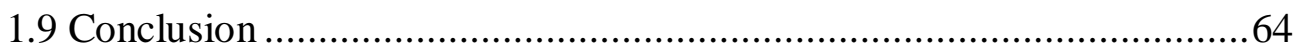

\section{CHAPTER 2}

Chick lit for the Italian marketplace? Toward a local production ...........66

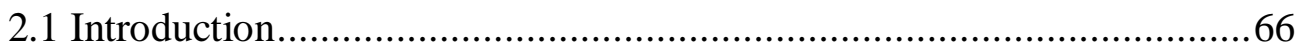

2.2 Italian popular romance: romanzo rosa and its evolution ....................67

2.3 Chick lit between globalization and local adaptations ..........................83

2.4 The making of Italian chick lit: Un anno di Gloria (2001), Valentina compra tutto (2002) and Qualcosa bolle in città (2004)...........................................................................90

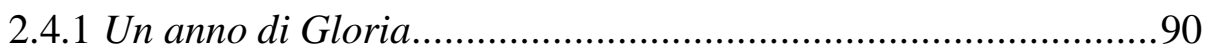


2.4.2 Valentina compra tutto

2.4.3 Qualcosa bolle in città

2.5 Conclusion

\section{CHAPTER 3}

Consolidating the genre: Federica Bosco's 'trilogia di Monica'

3.1 Introduction.

3.2 Newton Compton, Anagramma and the Italian marketplace.

3.3 Anagramma's paratext: marketing Italian chick lit

3.4 Federica Bosco: the 'queen' of Italian chick lit

3.5 The 'trilogia di Monica': Mi piaci da morire (2005),

$L$ 'amore non fa per me (2007) and L'amore

mi perseguita (2008)

3.6 Growing up, growing out: in search for an individual voice

3.7 Popular culture and quality fiction: intertextual references and literary icons in the 'trilogia di Monica'

3.8 Conclusion

\section{CHAPTER 4}

Realism and popular postfeminism in Italian chick lit novels

4.1 Introduction

4.2 Professional women between flexibility and precariato

4.3 Voglio un mondo rosa shokking (2007): Italian chick lit and popular postfeminism

4.4 A 'shokking' choice: the ambiguous realism of Voglio un mondo rosa shokking.

4.5 Love on a shoestring: unemployment and flexibility in Glam cheap (2007)

4.6 Mogli Mantenute, Mariti Licenziati and Uomini Extralarge:

negotiating female and male identities in the marketplace.

4.7 Conclusion 


\section{CHAPTER 5}

Romance, humour and intertextuality: Stefania Bertola's romantic comedies

5.1 Introduction.

5.2 Bertola's romantic comedy: female storytelling and narrative modes

5.3 Comedy, humour and intertextuality in Bertola's fiction....................211

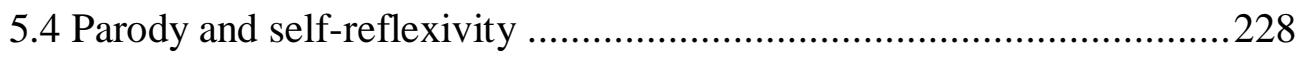

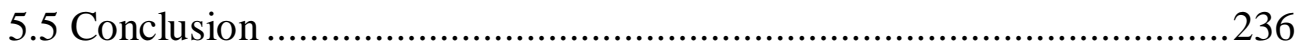

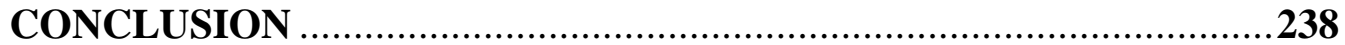

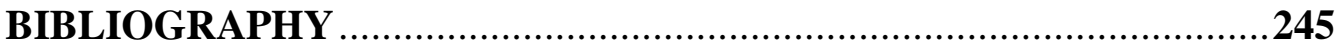




\section{LIST OF ILLUSTRATIONS}

Figure 1: Book cover of Bridget Jones's Diary by Helen Fielding...................... 93

Figure 2: Book cover of Il diario di Bridget Jones by Helen Fielding .................. 93

Figure 3: Book cover of Un anno di Gloria by Alessandra Casella..................... 93

Figure 4: Book cover of I love shopping by Sophie Kinsella ...........................107

Figure 5: Book cover of Valentina compra tutto by Carlotta Magnanini ..............107

Figure 6: Anagramma promotional picture in Newton Compton's

catalogue, 2009

Figure 7: Anagramma promotional picture in Newton Compton's catalogue, 2010

Figure 8: Book covers of Mi piaci da morire, L'amore non fa per me,

L'amore mi perseguita by Federica Bosco 


\section{INTRODUCTION}

In 2004, Federico Moccia's debut novel Tre metri sopra il cielo took Italy's publishing market by storm. Not only did it sell millions of copies and dominate the bestseller list for months, but it also spawned a sequel (Ho voglia di te, 2006) and two blockbuster movies, all equally successful among readers (and viewers) of all ages. ${ }^{1}$ Set in Rome, Tre metri sopra il cielo chronicles the love story between Babi, an upper-class teenage girl, and a rebellious young man named Step, reappraising the juxtaposition of dangerous man and innocent woman typical of popular romance novels within the context of contemporary Italian youth culture. Indeed, the success of Moccia's novel is based on the way in which it captures the everyday life of teenagers in Rome, pouring their dialogues and sentimental troubles into an otherwise simple and all too familiar plot. As Giovanna Rosa rightly observes, 'Moccia riprende lo schema paradigmatico della narrazione rosa, calando i conflitti del cuore nel nostro frenetico presente'. ${ }^{2}$ In making reference to the narratives of romanzo rosa, Rosa assesses Moccia's work as the modern updated version of a popular genre deeply rooted in the Italian tradition and characterised by its focus on courtship, melodrama and passionate feelings, which I will detail in the second chapter of this thesis.

\footnotetext{
${ }^{1}$ Federico Moccia, Tre metri sopra il cielo (Milan: Feltrinelli, 2004); Ho voglia di te (Milan: Feltrinelli, 2006). The book was first published in 1992 at the author's expense and it rapidly became a 'cult book' among high school students in Rome. The 2004 version is in fact an abridged edition that updates the original story to a contemporary setting. It has been translated into German, Spanish, Dutch, Greek, Portuguese and Korean. By 2006, the book had sold more than 1,000,000 copies; by 2007, together with the sequel, it had reached sales figures of 2,300,000 copies. Ranieri Polese, 'Bye bye America, il bestseller torna in Italia', Il Corriere della Sera, 13 November 2007, p. 49 <http://archiviostorico.corriere.it/ 2007/ novembre/13/Bye_bye_America_bestseller_torna_co_9_071113035.shtml> [accessed 2 May 2010]. ${ }^{2}$ Giovanna Rosa, 'L'amore come romanticheria. La riscossa del rosa', in Tirature 06, ed. by Vittorio Spinazzola (Milan: Gruppo editoriale il Saggiatore/Fondazione Mondadori, 2006), pp. 10-16 (p. 12).
} 
The exceptional reception of Tre metri sopra il cielo among readers, as well as the univocally dismissive reaction of the literary establishment, prompted Tirature, the yearbook on Italian publishing trends edited by literary critic Vittorio Spinazzola, to investigate the resurgence of sentimental fiction in Italy. ${ }^{3}$ Cleverly titled Di cosa parlano $i$ romanzi d'amore? the 2006 issue poses an apparently rhetorical question: if romanzi d'amore are by definition about 'romanticherie', romantic nonsense, what else could be possibly said about their content? Yet the contributors suggested interpretations that moved beyond conventional stereotypes and explored the various standpoints from which 'love stories' can be discussed, analysed and commented on, drawing attention to the variety and complexity of sentimental narratives and their recent evolution in contemporary Italy. In concluding her essay on Moccia's novel, Rosa writes that the controversial appeal of Tre metri sopra il cielo resides precisely in the clever blend of rosa sentimentalism and the coming of age narrative of young adult fiction. Most importantly, however, Rosa draws attention to the stark contrast between the conservative 'pathos ultraromantico' of the male popular writer and the works of critically acclaimed female writers who, in the same years, chose to narrate love and emotions in bleak and often disturbing terms. Between these two contrasting poles, Rosa concludes, a space is left vacant: 'Aperto resta un problema di non poco conto: come raffigurare l'intreccio di sessualità e desiderio amoroso delle donne di oggi, evitando le convenzionali sdolcinatezze [...] senza precipitare nei vortici di una prosa elitaria che nulla concede all'empatia e al piacere di lettura?'4

\footnotetext{
${ }^{3}$ Vittorio Spinazzola (ed.), Tirature 06. Di cosa parlano i romanzi d'amore? (Milan: Gruppo editoriale il Saggiatore/Fondazione Mondadori, 2006).

${ }^{4}$ Rosa, 'L'amore come romanticheria', p. 16.
} 
Taking the lead from Rosa's final observation, this thesis investigates Italian chick lit, that is, a critically overlooked segment of popular fiction that features stories of contemporary women caught between assertive sexuality and romantic emotions, while simultaneously trying to avoid the traps of both sugariness and literary elitism. As I discuss in Chapter 1, chick lit is a fiction genre that developed in Englishspeaking countries in the mid-late 1990s within the so called 'chick culture', a popular cultural phenomenon aimed at white, middle-class, heterosexual women in their $20 \mathrm{~s}$ and 30s that encompasses movies, magazines, books and many other media products. ${ }^{5}$ Deeply entangled with Western popular postfeminism and its sociocultural contradictions, chick culture addresses financially independent women by promoting discourses of self-empowerment, femininity, sexuality, consumerism and personal choice. Writing about cinematic romantic comedies, often inscribed in the chick culture framework, Celestino Deleyto has noted that the latest developments of the genre offer a commentary on the 'contemporary white middle-class heterosexual scene from a female perspective', ${ }^{6}$ a poignant definition that may very well be applied to chick lit. Indeed, heterosexual middle-class women are simultaneously the subject and the object of the narrative matter, where the female perspective is delivered through a witty and humorous prose that is the most defining trait of the genre.

While chick lit has gathered extraordinary media and public attention, in terms of sales and readers' reception, the term itself has often been used pejoratively, and the limitations pointed out by literary critics range from endless solipsism in terms of

\footnotetext{
${ }^{5}$ Suzanne Ferriss and Mallory Young, Chick Flicks. Contemporary Women at the Movies (New York: Routledge, 2007), p. 1-3.

${ }^{6}$ Celestino Deleyto, The Secret Life of Romantic Comedy (Manchester: Manchester University Press, 2009), p. 154.
} 
authorship and subject matter, to predictable narrative formulas that entertain the readers superficially without challenging them. ${ }^{7}$ However, following Mallory Young and Susanne Ferriss's pioneering 2006 book Chick Lit: The New Woman's Fiction, ${ }^{8}$ in the last decade more and more scholars have analysed and commented on chick lit from various disciplines, particularly in popular culture, media and feminist studies. As Imelda Whelehan (2009) points out, chick lit must be acknowledged as 'a tendency found in popular women's writing of the late twentieth and early twenty-first century which alerts us to key concerns and themes also to be found in popular culture more generally'?

In Reading the Popular (1989), John Fiske analyses the relationship between popular culture and the social context in which it is produced and received, drawing attention to the dynamic process that such a relationship entails:

popular culture is always in process; its meanings can never be identified in a text, for texts are activated, or made meaningful, only in social relations and in intertextual relations. This activation of the meaning potential of a text can occur only in the social and cultural relationships into which it enters. $^{10}$

Fiske argues that while popular cultural texts are without doubt the product of

dominant views and ideologies, the audience however does not consume them

\footnotetext{
${ }^{7}$ Beryl Bainbridge and Doris Lessing have famously dismissed the genre as 'a froth sort of thing' and the epitome of 'hopeless girls, drunken, worrying about their weight' respectively. Cited in John Ezard, 'Bainbridge tilts at "chick lit" cult', The Guardian, 24 August 2001 [Accessed 28 January 2008]. For an overview of the debate around chick lit in the early 2000s in the US and UK, see Hanne Blank, 'Don't Hate Me Because I'm Cute', Baltimore City Paper (10 September 2003) <http://www.citypaper. com/special/story.asp?id=5973> [accessed 10 February 2008]; Heather Cabot, "“Chick Lit” Fuels Publishing Industry', ABCnews.com, 30 August 2003 <http://abcnews.go.com/WNT/story?id=129475 \&page $=1>$ [Accessed 28 January 2008]; Scarlett Thomas, 'The Great Chick Lit Conspiracy', Independent, 4 August $2002<\mathrm{http} / / \mathrm{www}$.independent.co.uk/arts-entertainment/books/features/thegreat-chick-lit-conspiracy-638935.html $>$ [accessed 28 January 2008].

${ }^{8}$ Suzanne Ferriss and Mallory Young, Chick Lit: The New Woman's Fiction. (London and New York: Routledge, 2006).

${ }^{9}$ Imelda Whelehan, 'Teening Chick lit?', Working Papers on the Web, 13, (2009).

<http://extra.shu.ac.uk/wpw/chicklit/whehelan.html> [accessed 15 December 2009].

${ }^{10}$ John Fiske, Reading the Popular (London and New York: Routledge, 1989), p. 3.
} 
passively. In fact, continues Fiske, popular cultural texts are essentially inanimate until they engage in an intertextual dialogue with other texts: it is their circulation through the sociocultural landscape that brings them to life and unleashes all their potential meanings. Furthermore, Fiske highlights the central role that the audience plays in activating these texts by stressing the concept of 'relevance' in popular culture, which he locates 'at the intersection between the textual and the social'; as a consequence, relevance is 'a site of struggle' inasmuch as it is the result of an intertextual and openended process where the audience constantly and actively challenges the views and ideologies offered by the popular cultural texts they consume. ${ }^{11}$

The arrival of chick lit and its successful translation into Italian in the late 1990s prompted many local writers to engage with the genre, fostering domesticallyproduced texts that are consistent with Fiske's analysis of intertextual dialogues occurring among popular cultural texts. Some Italian critics and reviewers have recently started to examine the sociological reasons behind the genre's success and the generational representations that emerge from its contents, yet the object of their enquiry has been strictly confined to foreign chick lit novels translated into Italian, with local works going mostly unnoticed. ${ }^{12}$ The few who have analysed the Italian

${ }^{11}$ Fiske, Reading the Popular, p. 6.

${ }^{12}$ Alfonso Amendola, ed., È tutto Sex and the City: Moda, metropoli, amicizia e seduzione in una fiction televisiva (Napoli: Liguori, 2011); Maria Corbi, 'Piccole pollastre leggono', La Stampa, 02 September 2003, p. 23; Maria Novella De Luca, 'Passioni e intrighi senza lieto fine: così cambia il romanzo per single', La Repubblica, 21 February 2002, p. 30; Daniela De Rosa, 'Chick Lit, Lad Lit, Click Lit', in Tirature 05, ed. by Vittorio Spinazzola (Milan: Gruppo editoriale il Saggiatore/Fondazione Mondadori, 2005), pp. 70-74; Silvia Giovanetti, 'Chick-lit: una letteratura "rosa shopping", in Luigi Del Grosso Destrieri and others, Una galassia rosa: Ricerche sulla letteratura femminile di consumo (Milan: Franco Angeli, 2009), pp. 85-136; Susanna Mati, Sex and the City: Favola della donna single (Bergamo: Moretti \& Vitali, 2011); Laura Pugno, 'Chick lit, (post)romantiche senza miele', Il manifesto, 28 December 2005; Maria Paola Romeo, 'Narrativa sostantivo femminile', Giornale della Libreria, 119 (2006), pp. 38-43; Aglaia Viviani, 'Eroine del nuovo millennio', Leggendaria, 43 (2004) <http://www.libreriadelledonne.it/ Stanze/Paradiso/Nespole/Leggendaria2.htm> [accessed 15 January 2008]. 
production have noticed the accessibility of the fictional world portrayed and the humorous tone, particularly in comparison to mainstream popular romance, ${ }^{13}$ but the growing body of chick lit written in Italian and its place in the cultural and literary landscape have yet to be assessed. In light of Fiske's concept of 'relevance', among the many novels produced in Italy under the umbrella term of chick lit since the early 2000s I have selected those that explicitly intersect with critical frameworks such as chick culture, postfeminist media culture and popular romance, focusing on recurring themes, narrative structure and linguistic features in order to investigate the articulation of the genre in Italy and the many intertextual processes at work within it. Drawing on the Anglo-American framework of discussion on the weight of chick lit in popular culture, the novels presented here account for the genre's evolution and relevance in Italy's sociocultural and literary scene. As my critique is the result of an interdisciplinary perspective, one where close textual analysis merges with thematic readings, each chapter has a different emphasis. While such a flexible framework is vulnerable to the loss of analytical focus, following a single stream of criticism would be equally at risk of passing over the controversial versatility of the genre. Thus although my investigation is carried out primarily in the context of popular culture and genre fiction, at the same time I am influenced by cultural studies and feminist theories on women's popular culture and popular postfeminism, which provide insightful commentary on the polarising nature of chick lit as both a literary genre and a sociocultural phenomenon.

Chapter 1 provides an overview of the genre and presents the critical framework of my discussion, assessing the controversial term 'chick lit' and, more generally, the

${ }^{13}$ Laura Lepri, 'L'amore come commedia', in Tirature 06, ed. by Spinazzola, pp. 33-38. 
multifaceted and often contradictory discourses on 'girl power' and 'chick culture' in Western media and popular culture. In this context, I draw attention to some of the most influential Anglo-American chick lit novels as key texts in the making of the genre, and particularly Helen Fielding's Bridget Jones's Diary (1996); Candace Bushnell's Sex and the City (1996); Sophie Kinsella's The Secret Dreamworld of a Shopaholic (2000); Marian Keyes's Sushi for Beginners (2000); Melissa Senate's See Jane Date (2001); Jennifer Weiner's Good in Bed (2001); and Lauren Weisberger's The Devil Wears Prada (2003). ${ }^{14}$ I outline narrative elements and writing styles, also examining the books' physical characteristics in light of Gérard Genette's seminal studies on the paratext. ${ }^{15}$ As we shall see, chick lit is a genre largely defined by and identified with its paratext; book covers in particular, with their colourful tones and cartoon silhouettes, have moved from a basic staple to an editorial trademark across the globe. Not only have chick lit covers facilitated the commercial marketing of the novels worldwide, but they have also influenced enormously their cultural and critical reception. In the first chapter, I also discuss humour as the most important feature of the genre and examine its pivotal role in the narrative as a tool for both passive complicity and active engagement with postfeminist media culture. Indeed, as feminist cultural theorist Teresa Ebert has noted, with its scepticism 'about the whole idea of

\footnotetext{
${ }^{14}$ Candace Bushnell, Sex and the City (New York: Warner Books, 1996); Helen Fielding, Bridget Jones's Diary (London: Picador, 1996); Marian Keyes, Sushi for Beginners (London: Michael Joseph; Penguin, 2000); Melissa Senate, See Jane Date (Richmond: Red Dress Ink, 2001); Sophie Kinsella, The Secret Dreamworld of a Shopaholic (London: Black Swan, 2000); Jennifer Weiner, Good in Bed (New York: Pocket Books, 2001); Lauren Weisberger, The Devil Wears Prada (New York: Doubleday, 2003). ${ }^{15}$ Gérard Genette, Paratexts. Thresholds of Interpretation (Cambridge: Cambridge University Press, 1997).
} 
love as fulfilment', chick lit stands out as 'the romance of postcontemporary cynical reason' ${ }^{16}$

Chapter 2 focuses on early Italian chick lit novels and investigates if and how the original genre was not just adopted by Italian writers, but adapted to the Italian cultural and literary framework. First of all, I introduce the wider context of romanzo rosa, its cultures and practices as well as its legacy, providing a theoretical background to discuss Italian chick lit as the merging of cultural and stylistic elements derived from opposite directions: the local tradition and contemporary Anglo-American models. My approach draws on Anne Cranny-Francis's influential work on popular culture, particularly her concept of intertextuality as a powerful tool that allows critics to explore and discuss the textual strategies and conventions at work in a genre. ${ }^{17}$ At the same time, I look at how local cultures engage with forms of global entertainment. In this context, I take the lead from Joseph Straubhaar's idea of 'cultural proximity', which refers to a complex and relatively recent phenomenon in which the heavy consumption of imported cultural products has fostered the creation of indigenous ones that are 'closer to and more reinforcing of traditional identities, based in regional, ethnic, dialect/language, religious, and other elements' ${ }^{18}$ From this perspective I conduct a close analysis of Alessandra Casella's Un anno di Gloria (2001), Carlotta Magnanini's Valentina compra tutto (2002) and Camilla Vittorini’s Qualcosa bolle in città (2004), ${ }^{19}$ investigating their textual and paratextual elements. All published in the

\footnotetext{
${ }^{16}$ Teresa L. Ebert, The Task of Cultural Critique (Champain: University of Illinois Press, 2009), pp. 104-05.

${ }^{17}$ Anne Cranny-Francis, Popular Culture (Geelong: Deakin University Press, 1994), p. 18.

${ }^{18}$ Joseph D. Straubhaar, 'Beyond Media Imperialism: Asymmetrical Interdependence and Cultural Proximity', Critical Studies in Mass Communication, 8, (1991), 39-59 (p. 51).

${ }^{19}$ Alessandra Casella, Un anno di Gloria (Milan: Salani, 2001); Carlotta Magnanini, Valentina compra tutto. Una guida allo shopping metropolitano a Roma, Parigi, Londra (Reggio Emilia: Aliberti, 2002);
} 
early 2000s, the three novels were among the first to openly claim a direct connection with their Anglo-American models by taking successful chick lit bestsellers as the primary source of inspiration and trying to produce a genuinely domestic version of the genre, one that would seem to be consistent with the idea of 'cultural proximity' theory outlined by Straubhaar: these works are written by Italian authors, with Italian characters and Italian locations, presenting social and cultural issues relevant to Italian women. Using intertextual analysis to assess these novels from both the textual and the generic point of view, two distinct trends emerge: on the one hand, each novel differs greatly from the others not only in the approach to the original model, but also in the narrative it produces, revealing a versatility in the chick lit genre that confirms its remarkable drive in contemporary popular culture worldwide; on the other hand, the three novels fall short, each in its own way, of turning their overt dialogue with chick lit into a literary and cultural strength within Italy's genre fiction. Despite their shortcomings, I believe that the importance of the three books lies in the fundamental role they played in establishing a basic framework for a commercial and literary phenomenon that publishers wanted to introduce to the Italian audience.

Chapter 3 offers a different example of 'cultural proximity' in genre fiction, one that presents a successful combination of local and international features that appeals to the local audience, as represented in the so-called 'trilogia di Monica' written by Federica Bosco and published by Newton Compton's imprint Anagramma: Mi piaci da morire (2005), L'amore non fa per me (2007), and L'amore mi perseguita (2008). ${ }^{20}$ Translated into Spanish, German and Portuguese, among other languages, the three 
books have sold more than 400,000 copies to date - something quite unusual for a relatively minor genre. ${ }^{21}$ Before analysing the texts, I discuss the role of Anagramma, currently the leading Italian chick lit imprint, outlining its orientation toward popular romance and Italian chick lit in particular, as well as its role in encouraging a new crop of Italian writers to try out the genre. Among these writers, I focus on Federica Bosco, whom critics and readers of the genre have crowned the most representative Italian chick lit author. I show how Bosco and Anagramma helped each other in endorsing chick lit in Italy, with Anagramma's paratextual features playing a significant role with regard to the visual impact of the genre in (and for) the local market. In fact, the success of the trilogy demonstrates how factors such as a dedicated imprint and the character's serialisation have been instrumental to the affirmation of Italian chick lit as a genre in itself.

My textual analysis of Bosco's three novels looks at how they deploy the narrative trends set up by chick lit, such as the focus on a female protagonist, her journey toward self-empowerment and, most importantly, the humorous style. Indeed, almost every review praises Bosco's lightweight but realistic portrayal of young Italian women who are coping with a range of anxieties and expectations thanks to humour and optimism. As we shall see, however, from the second instalment humour is gradually left at the door as Bosco seems to consider it less and less appropriate to validating a tale of female empowerment, and I read the increasing seriousness of her writing as both the legacy of traditional romanzo rosa as well as the attempt to upgrade her writing from the (alleged) frivolity of chick lit. I also explore the intertextual dialogue that Bosco's

${ }^{21}$ Newton Compton Editori website, <http://www.newtoncompton.com/index.php?lnk=600> [accessed 10 March 2010]. 
trilogy performs with Anglophone popular culture and media, which, at various stages during the narration, helps the writer to build a shared background with her readership, contextualising her stories in a space that is both local and global, literary and popular, real and fictional.

In Chapter 4, I address specifically the relationship between chick lit, popular postfeminism and postfeminist media culture that mark the Anglophone scholarship but is to date virtually unexplored in Italian studies, with a specific focus on the representation of working women. Indeed, stories that centre on working women are a well-established subgenre in Anglo-American chick lit, the most famous example being Lauren Weisberger's The Devil Wears Prada (2003). ${ }^{22}$ In line with the genre's canon, all the novels I discuss in this thesis address the work and career choices available to middle-class, white, professional Italian women; yet, two in particular engage with issues that are specifically local, such as lavoro precario and job flexibility: Rossella Canevari and Virginia Fiume's Voglio un mondo rosa shokking (2007) and Lisa Corva's Glam cheap (2007). ${ }^{23}$ I begin by presenting a brief overview of the recent reforms in employment contracts in Italy and their implications against the cultural backdrop of posto fisso, explaining their impact on workers and women in particular, then I examine how the two novels bring them into the narrative. Published in the same year and set in middle-class Milan, both narratives centre around assertive women employed in the media industry who negotiate ideas of self-sufficiency in the working and private sphere through notions of femininity, choice, and selfdetermination borrowed from discourses of popular postfeminism. These similarities

${ }^{22}$ Lauren Weisberger, The Devil Wears Prada (New York: Doubleday, 2003).

${ }^{23}$ Rossella Canevari, and Virginia Fiume, Voglio un mondo rosa shokking (Rome: Newton Compton, 2007); Lisa Corva, Glam cheap (Milan: Sonzogno, 2007). 
constitute a valuable vantage point from which to explore how each novel represents and deals with issues of flexible labour and precariato within the chick lit framework. While the characters in Voglio un mondo rosa shokking emphasise the positive aspects of job flexibility and self-employment, and ultimately welcome them as an opportunity for women to choose autonomously the types of work that better suit their needs, the protagonist of Glam cheap embodies a far less optimistic vision, equating as she does flexibility with precariato, and falling into a steady downward spiral that threatens her welfare. In doing so, the two novels reflect ambivalent discourses on professional and emotional fulfilment for contemporary women carried out by postfeminist discourses, especially in popular media; at the same time, their attention to aspects that are specifically Italian, such as the focus on posto fisso as a key element of social and cultural identity, represents a significant effort to infuse the chick lit genre with a local distinctiveness.

Finally, Chapter 5 pulls together various streams of analysis and offers an intertextual reading of Stefania Bertola's chick lit. Drawing on scholarly works conducted on parody and romantic comedy films (a well-established product of chick culture, also known as 'chick flicks'), notably Margaret A. Rose's Parody / Metafiction (1979) and Celestino Deleyto's The Secret Life of Romantic Comedy (2009), ${ }^{24}$ I explore humour and intertextuality in Bertola's fiction, arguing that through a crafted bricolage of various narrative codes her novels successfully negotiate traditional conventions and contemporary transformations of the genre. Indeed, Bertola blends chick lit and popular romance tropes, particularly those derived from the tradition of

${ }^{24}$ Deleyto, The Secret Life of Romantic Comedy; Margaret A. Rose, Parody / Meta-fiction (London: Croom Helm, 1979). 
romanzo rosa, in an intertextual narrative that explores the dynamics and possibilities of genre writing. If Italian popular romance had always been permeated by a 'serietà assorta, ${ }^{25}$ a distinctive tone of sombre seriousness appropriate to the educational message that the story was required to deliver to its (female) readers, Bertola turns her attention to the comedic nature of chick lit and uses humour precisely to parody and/or disrupt such formal rules and conventions, demystifying their usual frame of reference. In a recent work on the dynamics of seriality and innovation in contemporary media, Umberto Eco has described a specific kind of intertextuality, which he calls 'the ironic quotation of the commonplace'. ${ }^{26}$ At the core of this kind of intertextual dialogue, Eco maintains, there is an 'intertextual encyclopaedia' of topoi that goes back and forth between the writer and the audience, one that assumes a shared knowledge of each commonplace and that subsequently plays upon the expectations generated by them in order to understand and appreciate the ironic connotations of the actual outcome. ${ }^{27}$ As we shall see, in Bertola's fiction the intertextual discourse put in place through the 'ironic quotation of the commonplace' is also one of self-critical reflexivity, since its ultimate target is romantic fiction in all its generic variations.

Before I conclude this introduction, I would like to clarify my position with regard to the term 'chick lit' itself: on the one hand, it is a marketing ploy universally (and often harshly) used as shorthand for cheap commercial fiction aimed at women; on the other hand, it refers to a genre so diverse that it resists a precise or unambiguous definition. Rather than discounting the term or trying to come up with an Italian

\footnotetext{
${ }^{25}$ Vittorio Spinazzola, L'immaginazione divertente. Il giallo, il rosa, il porno, il fumetto (Milan: Rizzoli RCS, 1995), p. 54.

${ }^{26}$ Umberto Eco, 'Innovation \& Repetition: Between Modern \& Postmodern Aesthetics', Daedalus, 134 (2010), 191-207 (p. 197).

${ }^{27}$ Eco, 'Innovation \& Repetition', p. 198.
} 
equivalent, I acknowledge the controversial polarisation it generates and welcome it as a strategic element of discussion. Whether happily embraced or forcefully rejected by critics, writers and readers alike - chick lit is an expression that has generated a great deal of debate in the social, cultural and literary arena, and I believe it must be approached as both a literary genre and a cultural phenomenon. Cranny-Francis has noted that popular cultural texts 'are not passive reflectors, but active potentials, whose meanings are differently accessed by different audiences, sometimes in ways that are utterly confusing to a mainstream reader or viewer or hearer' ${ }^{28}$ My claim is that all of the chick lit novels discussed in this dissertation are 'active potentials', and are indeed 'utterly confusing' upon close reading, making room for different and often clashing attitudes toward the subject matter they deal with and the literary features they present. As such, far from being a hopeless effort, a serious scholarly attempt to gain access to their meaning is instead a thought-provoking journey into the multifaceted nature of contemporary women's popular fiction.

${ }^{28}$ Cranny-Francis, Popular Culture, p. 1. 


\section{CHAPTER 1 - Chick lit: themes, features and critical assessment}

\subsection{Introduction}

In this chapter I briefly trace the origins of chick lit as a popular fiction genre, assessing the term 'chick lit' itself and, more generally, the cultural and social phenomenon of chick culture. Then I draw attention to pivotal Anglo-American chick lit novels as key texts in the making of the genre, which I read against the backdrop of critical intertextuality, popular fiction studies and discourses of popular postfeminism; in this context, I look also at the books' paratext, showing how chick lit's physical elements, notably the book covers, have become the most defining attribute of the genre in the marketplace. In addition, I address a significant feature of these novels, that is, humour and irony as the preferred narrative mode, and discuss its pivotal role in rewriting discourses on love, consumerism and social relationships. The final part of the chapter is dedicated to the critical assessment of the genre and looks at the various perspectives that have populated the debate around chick lit so far.

\subsection{Chick lit and postfeminist popular culture}

Scholars agree that, since its first appearance on the literary scene, chick lit has been particularly resistant to clear-cut definitions, except, perhaps, that it is 'the most culturally visible form of postfeminist fiction'. ${ }^{1}$ The term itself is a disputed one: indeed, it was American novelist and editor Cris Mazza who used it for the first time in 1995, as the title for the anthology of women's short stories she co-edited with Jeffrey

\footnotetext{
${ }^{1}$ Stephanie Harzewski, Chick Lit and Postfeminism (Charlottesville and London: University of Virginia Press, 2011), p. 8.
} 
DeShell: Chick-Lit: Postfeminist Fiction. ${ }^{2}$ Working from a feminist perspective, Mazza's intent was to find stories that were 'simultaneously courageous and playful; frank and wry; honest, intelligent, sophisticated, libidinous, unapologetic, and overwhelmingly emancipated [from] the grim anger that feminists had told us ought to be our pragmatic stance in life' ${ }^{3}$ By calling on semantically charged terms such as 'chick' and 'postfeminist', Mazza promoted a kind of subversive fiction rooted in feminist women's writing but in opposition to the traditional forms available to writers and generally acknowledged by academic feminism, which she perceived as too constraining. Diane Goodman's review of the anthology calls for a critical reading of both 'chick' and 'post', correctly addressing the contradictory message sent by the two prefixes:

Chick-Lit [...] explores, explains, sometimes gives into and sometimes blows away the notion of a chicklet [...] The anthology calls up all of the subtle differences in the prefix post and introduces multi-leveled ideas of feminism - it's historical, political, social, economic; it's funny, sad, dramatic, mean, indulgent, moving, scary. [...] This collection of fiction draws from the past and addresses a future that forces us to confront a new array of situations as we move toward the year $2000 .^{4}$

The above passage draws attention to the ironic and thought-provoking commentary on 'new situations' concerning young women, and Goodman's analysis brings to the forefront the fact that Mazza's anthology arose from postfeminist discourses that were stirring feminist scholarship in the 1990s, debating whether the prefix 'post' should be read as 'against' or 'after' the feminist movement of the 1960s and 1970s. The analysis

\footnotetext{
${ }^{2}$ Chick Lit Postfeminist Fiction, ed. by Cris Mazza and Jeffrey DeShell (Normal, Illinois: FC2, 1995).

${ }^{3}$ Cris Mazza, 'Who's Laughing Now? A Short Story of Chick Lit and the Perversion of a Genre', in Chick Lit: The New Woman's Fiction, ed. by Suzanne Ferriss and Mallory Young (New York:

Routledge, 2006), pp. 17-28 (p. 18).

${ }^{4}$ Diane Goodman, 'What is Chick Lit?', Electronic Book Review, 1996. <http://www.electronicbook review.com/thread/writingpost feminism/gutsy> [accessed 28 January 2008].
} 
of this complex debate would go beyond the scope of this thesis; for the purpose of my analysis, I turn to Sarah Projansky's thorough investigation of postfeminism in popular culture to briefly touch upon its various yet entwined definitions. ${ }^{5}$ Projanski outlines five categories of postfeminism, which she calls 'linear', 'backlash', 'equality and choice', '(hetero)sex-positive' and 'men can be feminist too', emphasising both the versatility and ambivalence of the concept. ${ }^{6}$ Whether postfeminism should be intended as a rejection of the feminist movement of the 1960s (the 'backlash' outlined by Susan Faludi in her groundbreaking book by the same name ${ }^{7}$ ), a transition / revision of the latter in line with changes in contemporary society ('linear' and 'equality and choice'), or the empowering affirmation of women's individuality and independence ('(hetero)sex positive'), Projansky argues that 'most versions of postfeminism can function as either a condemnation or a celebration of women and feminism [insofar as they all deal with] the effects of feminism in contemporary culture and life'. ${ }^{8}$ However, Projansky continues, the limits of postfeminism both in theory and in practice is particularly evident in its focus on white, middle-class, and heterosexual women, which bypasses issues of race, social status and sexual identity. ${ }^{9}$

\footnotetext{
${ }^{5}$ Sarah Projansky, Watching Rape. Film and Television in Postfeminist Culture (New York: New York University Press, 2001). For a comprehensive and accurate analysis of the scholarly literature on postfeminism, see Sarah Gamble, 'Postfeminism', in The Routledge Companion to Feminism and Postfeminism, ed. by Sarah Gamble (London: Routledge, 2001), pp. 43-53. Gamble discusses also 'third wave feminism', a body of thought developed as an answer to the debate around mainstream postfeminism that I do not intend to address in this dissertation. Third wave feminism embraces feminist subculture and political activism and seeks to apply them in relation to the time and place where it occurs. See also Stacy Gillis, Gillian Howie and Rebecca Munford, Third Wave Feminism: A Critical Exploration (Basingstoke and New York: Palgrave Macmillan, 2004); Stéphanie Genz, Postfemininities in Popular Culture (Basingstoke and New York: Palgrave Macmillan, 2009).

${ }^{6}$ Projansky, Watching Rape, pp. 67-68.

${ }^{7}$ Susan Faludi, Backlash: The Undeclared War Against American Women (New York: Crown, 1991).

${ }^{8}$ Projansky, Watching Rape, p. 86.

${ }^{9}$ Projansky, Watching Rape, p. 87.
} 
In this context, Ann Brooks argues that much of the bias against discourses of postfeminism arises from its representation in the media, which translates it into a canny marketing label born out of a too simplistic anti/after dichotomy; by contrast, Brooks invites scholars to reclaim postfeminism as a conceptual and political shift that, within feminism, must focus on diversity and challenge 'the intersection of feminism with postmodernism, post-structuralism, and post-colonialism' ${ }^{10}$ Squarely put in the social and political practices of early feminism, Brooks's postfeminism is thus to be seen as a specific moment in time and history that 'facilitates a broad-based, pluralistic conception of the applications of feminism, and addresses the demands of marginalised, diasporic and colonised cultures'.11 As such, it significantly intersects with popular culture in so far as the latter is re-evaluated as 'an area of political and representational contestations' ${ }^{12}$

From this perspective, I believe that Brooks reasoning strongly resonates with much of Mazza's idea of 'postfeminist fiction', as her collection of short stories was intended as a critical deconstruction of feminism and its literary practices at the turn of the century. ${ }^{13}$ Yet within a couple of years after Mazza's subversive anthology, 'chicklit' had become the catchword for a galaxy of commercial fiction 'written by women, (largely) for women, depicting the life, loves, trials and tribulations of their

\footnotetext{
${ }^{10}$ Ann Brooks, Postfeminisms: Feminism, Cultural Theory, and Cultural Forms (London and New York : Routledge, 1997), p. 4.

11 Brooks, Postfeminisms, p. 4.

12 Brooks, Postfeminisms, p. 162. Brooks uses pop star Madonna as the paradigm of such area of contestation.

${ }^{13}$ In this respect, I should point out that the work of Italian writer Rossana Campo (b. 1963) could fall within Mazza's postfeminist fiction, highlighting the presence of analogous tensions in 1990s Italy's literary landscape. As Stefania Lucamante has noted, Campo's 'quintessential' post-feminist writing emerges through a 'new (female) rhetoric of language ("talk as you fuck")' that 'place[s] female readership, on the same level as her characters, with everyday problems connected to love, money and work'. See Stefania Lucamante, A Multitude of Women: The Challenges of the Contemporary Italian Novel (Toronto: University of Toronto Press, 2008), pp. 15-16.
} 
predominantly young, single, urban, female protagonists'. ${ }^{14}$ While both versions of the genre are certainly to be read against the social and cultural postfeminist backdrop, the new wave of commercial chick lit avoids any active engagement with 'traditional' feminism and feminist writing and glides along 'chick culture' and 'girl power', the media-driven phenomena emerged in mid-1990s British and American popular culture. Mallory Young and Susanne Ferris are among the scholars who have extensively investigated chick culture in all its diverse manifestations across media, suggesting that the word 'chick' should be considered as representative of the 'generational redefinitions of womanhood and women's rights, femininity and feminism, [marking] transformations of women's studies, from politics to popular culture, literature to film' ${ }^{15}$ One of the chief locations of these generational redefinitions is indeed 'girl power', a popularisation of feminist ideas and language that Stéphanie Genz describes as 'a playful/ironic reconfiguration and consumption of feminine signifiers' ${ }^{16}$ Based on a renovation of traditional femininity that plays on notions of self-empowerment and assertiveness, girl power reclaims feminine signifiers such as clothing and makeup and links them to ideas of autonomy and independence, giving girls and women with 'the agency to create [themselves] and negotiate the possibilities of [their] gender role'. ${ }^{17}$ However, the negotiation of traditional femininity does not come without a fair share of ambiguity and limitations: if the focus on consumer goods as the means through which exert agency questions the very same concept of autonomy and

\footnotetext{
${ }^{14}$ Sarah Gormley, 'Introduction', Working Papers on the Web, 13, (2009) <http://extra.shu.ac.uk/wpw/ chicklit/gormley.html> [accessed 15 December 2009].

${ }^{15}$ Suzanne Ferriss and Mallory Young, 'Chicks, Girls and Choice: Redefining Feminism', Junctures, 6 (2006), 87-97 (p. 87).

${ }^{16}$ Genz, Postfemininities in Popular Culture, p. 86. The term 'girl power' was coined in the late 1990s by UK pop band Spice Girls.

${ }^{17}$ Genz, Postfemininities in Popular Culture, p. 94.
} 
independence, the fact that girl power targets an audience made almost exclusively of middle-class white women suggests a rather narrow perspective as for the agency it advocates. In this respect, the emphasis on personal choice has prompted some scholars to discuss the relationship with discourses of self-improvement and individual empowerment in light of recent neoliberal politics, to which I shall return later on in Chapter 4, when discussing the representation of working women in the genre. ${ }^{18}$ Much like chick lit, girl power is thus a blanket concept that offers intertwined representations of contemporary women shaped by consumerism, female empowerment and personal choice, providing its audience 'with a feminist memory, mediated, rendered palatable and just critical enough to key into an apolitical sense of social dissatisfaction with heterosexual and gendered role scripts' ${ }^{19}$

\subsection{Popular fiction genres and intertextuality as a cultural practice}

Library collection guidelines and book reviews have helped readers and scholars to set out a basic map of the main chick lit authors and titles and to build a canon of the genre, ${ }^{20}$ yet a fixed definition of the genre and its formal features is still quite difficult to achieve. More than as a genre, chick lit should therefore be read as a cultural practice: as John Fiske maintains, 'genre is a cultural practice that attempts to structure some order into the wide range of texts and meanings that circulate in our culture for

\footnotetext{
${ }^{18}$ See for example Imelda Whelehan, Overloaded: Popular Culture and the Future of Feminism (London: The Women's Press, 2000) and Emilie Zaslow, Feminism, Inc. Coming of Age in Girl Power Media Culture (New York: Palgrave Macmillan, 2009).

${ }^{19}$ Imelda Whelehan, 'Remaking Feminism: Or Why Is Postfeminism So Boring?', Nordic Journal of English Studies, 9, 3 (2010), 155-72 (p. 160).

${ }^{20}$ Stephanie Davis-Kahl, 'The Case for Chick Lit in Academic Libraries', Collection Building, 27 (2008); Diana Tixier Herald, 'Emerging Genres', in Genreflecting: A Guide to Popular Reading Interests, ed. by Wayne A. Wiegand (Westport: Libraries Unlimited, 2006), pp. 493-502 (pp. 499-502); Rebecca Vnuk, 'Hip Lit for Hip Chicks', Library Journal, 130, (2005), 42-45.
} 
the convenience of both producers and audiences' and, as such, it 'should be defined as a shifting provisional set of characteristics which is modified as each new example is produced ${ }^{21}$ Instrumental for the analysis of popular genres as cultural practices, Fiske continues, is intertextuality, which positions popular cultural texts at the crossroad of the social, cultural and political landscape that produces and consumes them and investigates the links among generic texts (horizontal intertextuality) and between the generic texts and other texts that refer explicitly to them (vertical intertextuality), such as publicity, reviews, criticism and so on. ${ }^{22}$ As I shall demonstrate throughout this thesis, discourses of intertextuality bring to the forefront a variety of junctures within and outside popular fiction texts, expanding their meanings and invoking a nuanced, more careful reading of them. More precisely, in the context of genre studies, the complex network of social, cultural and literary intertextual links has been addressed and examined particularly in regard to the shifting boundaries of popular genres, and in dealing with such a key concept I draw from the works of Rick Altman, John Frow and Italian critic Vittorio Spinazzola. ${ }^{23}$ While they all acknowledge the existence of codified genres, as well as standardised themes and formulas, these scholars challenge the idea of stable precincts from different theoretical perspectives, showing how such elements actually coexist in a framework of extremely fluid boundaries.

Altman's influential study of cinematic genres in Film/Genre (1999) offers an insight into genre theory and practice; although developed in the context of film genres, Altman's analysis is relevant to the discussion of any set of texts. Central to Altman's

${ }^{21}$ John Fiske, Television Culture (London and New York: Routledge, 1987), p. 109 and p. 111.

${ }_{22}^{22}$ Fiske, Television Culture, p. 115-17.

${ }^{23}$ Rick Altman, Film/Genre (London: BFI Publishing, 1999); John Frow, Genre (London and New York: Routledge, 2005); Vittorio Spinazzola, Il successo letterario (Milan: Unicopli, 1985); Vittorio Spinazzola, La modernità letteraria (Milan: Net, 2005). 
discourse is the concept of genrification, that is to say, the life-cycle of a genre: '[genre is] not the permanent product of a singular origin, but the temporary by-product of an ongoing process' ${ }^{24}$ In other words, Altman suggests that genrification is a cycle where new materials are associated with already existing genres in a ceaseless process of creation, consolidation and consumption of genres. ${ }^{25}$ He uses a broad range of theoretical insights to successfully demonstrate his argument. Focusing on the history and evolution of various Hollywood genre films (such as the Western, the musical and the woman's film), he presents the two main approaches adopted by genre critics, the semantic and the syntactic. The former is based on the recognition that multiple texts share the same building blocks, for example common themes and shared plots and characters, all of which provide consistency, easy identification and broad applicability. When the 'building blocks' are organised in similar manner, genres become tools for the analysis of syntactic aspects, that is to say, specific indications on how to read textual elements such as narrative structure and relationships between characters. Developing the discussion of theorists such as John Cawelti, Alastair Fowler and Ludwig Wittgenstein, who locate genres either in semantic or syntax, Altman proposes that 'the term genre takes its full force only when semantic and syntax are simultaneously operative'. ${ }^{26}$ Reading together the creative and commercial strategies behind genre labels, he draws attention to the discursive nature of genres, as they can simultaneously include or exclude each other, depending not only on what they want to communicate, but also on who is using them (for example the audience or the critic). Building on this idea, Altman argues that genres are 'multi-discursive' because they

${ }^{24}$ Altman, Film/Genre, p. 54.

${ }^{25}$ Altman, Film/Genre, pp. 61-65.

${ }^{26}$ Altman, Film/Genre, p. 90. 
are 'mechanisms for co-ordinating diverse users ${ }^{27}$. Indeed, each genre is always intertextual, that is to say, defined by multiple codes at the same time, corresponding to the different groups who may 'use' the genre in potentially contradictory ways. A second key element for my analysis of chick lit's main features is Frow's Genre, whose central argument is that texts are 'performances' rather than exact reproductions of the genre they belong to. Bearing in mind Michel Foucault's works on discourse analysis and speech act theory, Frow reads genres from a semiotic perspective and argues that they act as 'meaning-making': "far from being merely "stylistic" devices, genres create effects of reality and truth which are central to the different ways the world is understood in the writing of history $[\ldots] \cdot{ }^{28}$ Frow's argument is particularly interesting because it moves away from a hierarchical, taxonomic relationship between genres and texts and advocates a 'reflexive model', one where the texts 'perform the genres by which they are shaped'. ${ }^{29}$ The focus on the idea of performance rather than of belonging, influenced as it is by Jacques Derrida's discourse on textuality and genres, leads Frow to elaborate the notions of 'open-endedness of genres and the irreducibility of texts to a single interpretative framework' ${ }^{30}$ Therefore, his reflexive model acts also as a dynamic frame, one that allows (instead of restraining) different forms of performance in the genre.

Vittorio Spinazzola, who has dedicated a great deal of critical analysis to Italian popular fiction and its role in the marketplace, adopts a similar perspective with regard to genre fiction's success. Spinazzola argues that every success (be it commercial or critical) triggers imitative processes in the same field, specifying however that, in

\footnotetext{
${ }^{27}$ Altman, Film/Genre, p. 208.

${ }^{28}$ Frow, Genre, p. 19.

${ }^{29}$ Frow, Genre, p. 25.

${ }^{30}$ Frow, Genre, p. 28.
} 
genre writing, the effort should be comparative rather than absolute. ${ }^{31}$ In other words, a successful text is not one that passively replicates its leading predecessors, but one that is able to include a variation, that is, an innovative element that significantly enriches the given framework. At the same time, the reader's response to the writer's efforts is very much related to the ability of the latter to handle their models. Spinazzola thus argues that variation is pivotal because it fosters a dialogue between the text and the reader's expectations: 'L’imitazione coincide sempre con la variazione. [...] Nella concreta esperienza di lettura, il piacere del ritrovamento del già noto si accompagna sempre al compiacimento che dà l'assaporare l'inedito, l'ignoto. Varia solo il gioco delle proporzioni fra i due fattori, ${ }^{32}$ Successful genre fiction, then, is one where the integration of imitation and variation allows for something unexpected to be enjoyed by the reader.

As we shall see in the next pages, these theoretical insights on fiction genres come together in my analysis of chick lit: with its 'multi-discursive' and intertextual position across genres, chick lit is the ideal field for investigating how it successfully 'performs' different variations of the same model.

\subsection{Chick lit in the marketplace: from Bridget Jones (1996) to Red Dress Ink (2001)}

When outlining the origins of chick lit as a commercial genre, Helen Fielding's Bridget Jones 's Diary ${ }^{33}$ is the commonly recognised archetype. As Claire Squires aptly notes, nowadays Bridget Jones is 'not only a term for a certain social type [...]

\footnotetext{
${ }^{31}$ Spinazzola, ed., Il successo letterario, p. 14.

${ }^{32}$ Spinazzola, La modernità letteraria, p. 161.

${ }^{33}$ Helen Fielding, Bridget Jones's Diary (London: Picador, 1996).
} 
but also shorthand for a certain sort of novel and a certain sort of success' ${ }^{34}$ Published in 1996 in the United Kingdom by Picador, an imprint known for its interest in 'serious and innovative literary fiction', 35 the novel focused on a 'child of Cosmopolitan culture [...] traumatised by supermodels and too many quizzes'. ${ }^{36}$ In the same year and on the other side of the Atlantic, Candace Bushnell released Sex and the City, ${ }^{37}$ a collection of essays loosely based on her own experiences among Manhattan's elite circles during the 1990s.

Given these overlapping circumstances, similarities are often traced between the works of Fielding and Bushnell, notably the fact that both appeared for the first time as newspaper columns (the Independent and the New York Observer, respectively) and the innovative approach to fictionalised accounts of the lives of contemporary white, upper and middle-class single women in Western countries. Yet, the two novels could not be more different: Fielding's awkward character of Bridget Jones voiced the anxieties and shortcomings of contemporary women; Bushnell, by contrast, chose to portray 'high-achieving' women who unapologetically enjoy their glamorous lifestyle. ${ }^{38}$ Nonetheless, the underlying similarity holds true when read in the context of the publishing market of their time, where Fielding's confessional narrative and her 'observational humour', together with the overt borrowing of and homage to Jane

\footnotetext{
${ }^{34}$ Claire Squires, Marketing Literature: The Making of Contemporary Writing in Britain (New York: Palgrave Macmillan, 2007), p. 159. Squires's book includes a cogent case study of the publishing history of Bridget Jones's Diary, to which I will refer throughout this chapter.

35 Squires, Marketing Literature, p. 156.

${ }^{36}$ Fielding, Bridget Jones's Diary, p. 59.

${ }^{37}$ Candace Bushnell, Sex and the City (New York: Warner Books, c1996). Since its first appearance on the market, the book has been reprinted several times. All the excerpts in this dissertation refer to the Grand Central Publishing paperback edition published in 2006.

${ }^{38}$ Imelda Whelehan, The Feminist Bestseller: From Sex and the Single Girl to Sex and the City (New York: Palgrave Macmillan, 2005), p. 206.
} 
Austen's Pride and Prejudice, ${ }^{39}$ immediately became a 'paradigm of genre-crossing fiction [...] placed between the "mass" and the "literary" market, by appealing to and playing on the conventions of romance fiction'. ${ }^{40}$ Such a definition of 'genre-crossing fiction' fits Bushnell's novel as well, albeit with sharp and cynical snippets in place of lightweight comedic humour. Indeed, it has been noted that while indebted to Edith Wharton's fiction, the way Bushnell exposes the deceptive glamour of the Manhattan lifestyle often evokes the dark and harsh atmosphere of Brett Easton Ellis's American Psycho (1991) and Glamorama (1998). ${ }^{41}$ But it was the TV adaptation, which first aired in 1998 on American cable channel HBO and became an instant global success, that truly established a 'key cultural paradigm' for the repositioning of discourses on 'femininity, singlehood, and urban life', ${ }^{42}$ just like Fielding's novel had done two years before.

From what I have outlined so far, it is clear that the resounding success of Fielding and Bushnell's work (for the latter largely due to its TV adaptation) resides in their hybrid status, located as they are halfway between social commentary, escapist fiction and literary tradition. In terms of popular women's fiction in the marketplace, what is important to note is that such flexibility gave birth to a new format, so to speak, that captured the attention of publishers and (female) writers alike. The latter, whether

\footnotetext{
${ }^{39}$ Whelehan, The Feminist Bestseller, p. 185; Imelda Whelehan, Helen Fielding's Bridget Jones's Diary: A Reader's Guide (New York: Continuum, 2002), pp. 15-19.

${ }^{40}$ Squires, Marketing Literature, p. 160.

${ }^{41}$ The influence of Wharton on Bushnell's writing is well documented in Harzewski, Chick Lit and Postfeminism, pp. 108-114. References to Easton Ellis's themes and style are highlighted in Anna Kiernan, 'No Satisfaction: Sex and the City, Run Catch Kiss, and the Conflict of Desires in Chick Lit's New Heroines', in Chick Lit, ed. by Ferris and Young, pp. 207-18 (p. 211), and in James Annesley, Fictions of Globalization (London and New York: Continuum, 2006), pp. 33-36.

${ }^{42}$ Kim Akass and Janet McCabe, Reading Sex and the City (London and New York: I.B. Tauris, 2006), p. 2; Diane Negra, 'Quality Postfeminism? Sex and the Single Girl on HBO', Genders, 39 (2004) <http://www.genders.org/g39/g39_negra.html> [accessed 20 January 2008]. In this respect, one should keep in mind that the cheerful and uplifting tones of the TV adaptation are a far cry from the cynical mood that permeates the book.
} 
imitating the Bridget Jones's Diary style or rephrasing Sex and the City's themes into different formats, found in this kind of writing an ideal way to narrate stories of women looking for fulfilment, not limited to love but extending to family, friendship and work. Publishers, for their part, particularly those in the romance sector who were facing a slump in the market, saw the opportunity to explore a new and potentially lucrative area aimed at younger readers, and in 2001 mass-market romance publisher Harlequin Enterprises launched Red Dress Ink (RDI, 2001-2009), a dedicated imprint that built the canon for chick lit. ${ }^{43}$ The RDI Editorial Office provided exhaustive coordinates about the tools that authors needed in order to write for the imprint, stating that their goal was to capture and reflect the daily life of ordinary - that is, real women, with greater emphasis on their 'changing attitude toward love and marriage'. ${ }^{44}$ Looking at both Fielding and Bushnell's production, a pivotal tool for delivering this 'changing attitude' was the writing style, which RDI wanted to be fresh, innovative and able to address women's experiences and relationships with humour and irony. Eventually, chick lit developed into a specific genre characterised by a 'humorous and upbeat tone', typically written in the first person and portraying 'a world in which young women juggle the demands of career and relationship in a new and nontraditional way, ${ }^{45}$

\footnotetext{
${ }^{43}$ Louise Craddock, 'Bridget Jones's Little Red Dress. Chick lit, mass-market popular romance and feminism', Diegesis, 8 (2004), 42-50 (p. 44). Craddock's article examines RDI in the context of Harlequin and Mills \& Boon editorial strategies, highlighting how it marked a significant departure from the publisher's traditional romance format. Encouraged by sales figures, soon after RDI launched local branches across Europe, Italy included, contributing to the diffusion of the genre. More on this will be discussed in Chapter 2. See also Harzewski, Chick Lit and Postfeminism, pp. 31-32.

${ }^{44}$ Craddock, 'Bridget Jones's Little Red Dress', p. 47.

${ }^{45}$ Tixier Herald, 'Emerging Genres', p. 499 and p. 493, respectively. See also Sarah Mlynowski and Farrin Jacobs, See Jane Write: A Girl's Guide to Writing Chick Lit (Philadelphia: Quirk Books, 2006), a manual for aspiring chick lit writers. It is worth noting that Mlynowski is a well-known chick lit writer herself.
} 


\subsection{Chick lit's main features}

Among the most cited novels and writers that to some extent have contributed to creating and shaping the genre, either by reiterating the formula of Bridget Jones's

Diary or by introducing variations to the model, I have selected a mixed group of wellknown works across the range of the vast production of British and American chick lit from the mid-1990s to date. In deciding which novels to include, I have taken into account their position in the marketplace as well as their critical reception and recognition, for example by looking at their presence in The New York Times Bestsellers List or in scholarly works on the genre. In addition, because I intend to examine how Italian writers and novels perform in relation to the Anglo-American canon, for the purpose of my analysis I have reduced the list to British and American texts that fulfil two basic requisites: they must have been translated into Italian, and they must have been positively marketed by Italian publishers. ${ }^{46}$ Therefore, I have selected the following seven titles: Helen Fielding's Bridget Jones's Diary (1996); Candace Bushnell's Sex and the City (1996); Sophie Kinsella's The Secret

Dreamworld of a Shopaholic (2000); Marian Keyes's Sushi for Beginners (2000);

Melissa Senate's See Jane Date (2001); Jennifer Weiner's Good in Bed (2001); and

Lauren Weisberger's The Devil Wears Prada (2003). ${ }^{47}$ It is worth noting that

Bushnell's novel is largely unknown to readers, despite the success of the TV series it

\footnotetext{
${ }^{46}$ The catalogues and websites of Italian publishing houses active in the genre often include blurbs on specific novels and authors. For example, Piemme's imprint Bestseller, which publishes chick lit writers such as Candace Bushnell and Lauren Weisberger along with Italian Tiziana Merani, emphasises the 'must-have' qualities of its books: 'I libri che avete amato o che non potete perdere li trovate tutti qui! [...] solo i grandi successi entrano in PIEMME BESTSELLER'. Piemme Bestseller website, <http://www.piemmebestseller.it/about.view> [accessed 28 January 2008].

${ }^{47}$ Marian Keyes, Sushi for Beginners (London: Michael Joseph; Penguin, 2000); Melissa Senate, See Jane Date (Richmond: Red Dress Ink, 2001); Sophie Kinsella, The Secret Dreamworld of a Shopaholic (London: Black Swan, 2000); Jennifer Weiner, Good in Bed (New York: Pocket Books, 2001); Lauren Weisberger, The Devil Wears Prada (New York: Doubleday, 2003).
} 
has inspired. Nevertheless, the book represents an important element for the genre's development and as such it deserves critical attention; however, because the TV series is considered an iconic landmark for chick lit writers worldwide, particularly in Italy, I will refer to it as well when discussing the characteristics of the genre.

As Joanne Hollows brilliantly summarises, chick lit novels present 'a female protagonist seeking personal fulfilment in a romance-consumer-comedic vein'. ${ }^{48}$ Romance, consumerism, comedy and personal fulfilment are indeed the keywords that define chick lit in the literary scene. The protagonists are typically white, middle or upper class women in their 20s or 30s, working in the publishing, media or fashion industry; in other words, independent, working women are the core of chick lit and in this respect the genre addresses issues such as financial independence, a professional career and personal affirmation. The novels are written in a colloquial and witty style that, however, does not exclude the narration of more serious issues, such as single parenthood, abusive relationships, unemployment and depression, as in the case of Keyes's Sushi for Beginners and Weiner's Good in Bed. At the opposite side of the spectrum, Kinsella's The Secret Dreamworld of a Shopaholic and Fielding's Bridget Jones's Diary are cheerful novels in which, after a series of comedic misadventures, the protagonists fulfil their professional and sentimental goals. In light of Knowles's definition mentioned above, in the following pages I will look at chick lit's salient themes and formal elements, which operate as a basic template for the genre.

${ }^{48}$ Joanne Knowles, 'Editorial', Diegesis, 8 (2004), 3-4 (p. 3). 


\subsubsection{Romance and sexuality}

Even though chick lit novels are often considered a subgenre of contemporary romance, the two genres differ significantly. Scholar Pamela Regis defines the romance novel as 'a work of prose fiction that tells the story of the courtship and betrothal of one or more heroines'; ${ }^{49}$ the association of romance writers RWA (Romance Writers of America), on their part, identify two basic elements for the genre, that is, 'a central love story and an emotionally-satisfying and optimistic ending' in which the two lovers 'are rewarded with emotional justice and unconditional love'. ${ }^{50}$ Whereas the romance novel is traditionally focused on a unique male-female relationship, chick lit's focal point is rather the female character and her maturing experience, either personal or professional. Likewise, male characters are downsized into secondary roles, prompting a significantly different perception of their function not only in the story, but also (and most importantly) in the protagonist's life. This is not to say, however, that chick lit avoids romance altogether: a romantic subplot is frequently included in the narrative, yet the 'unconditional love' between man and woman is rarely accomplished at the end of chick lit novels, where the protagonist's achievement of self-esteem and a positive attitude toward life may or may not include a successful relationship. This is the case of The Devil Wears Prada, for example, where the protagonist Andy in the end takes control of her life and career but loses her boyfriend in the process. In See Jane Date, after many unsuccessful encounters Jane eventually finds the 'right' man, but the novel's epilogue glosses over their relationship, focusing

\footnotetext{
${ }^{49}$ Pamela Regis, A Natural History of the Romance Novel (Philadelphia: University of Pennsylvania Press, 2003), p. 14.

${ }^{50}$ Romance Writers of America, 'The Romance Genre Overview' <http://www.rwa.org/cs/ the_romance_genre> [accessed 3 February 2011].
} 
instead on the protagonist's newly achieved sense of balance: 'at six months, we were still getting to know each other, still getting to love each other. For the first time in my life, I felt as though I had all the time in the world'. 51

Furthermore, in a major shift from the traditional popular romance, in which sexuality is centred on one male partner, chick lit novels bring in sexually active protagonists and display various intimate encounters throughout the story, including one-night stands and, occasionally, same-sex experiences. These encounters are reported in a more or less explicit way, according to the writing style of each author; more than the way in which they are described, however, I would rather stress the recurrence of such situations. Indeed, the characters' ability to speak about intimate experiences and sexual gratification, in an open and guilt-free tone, is the most vital thread in the fabric of these novels. Read for example the following excerpt from Good in Bed:

I had slept with four people - three long-term boyfriends and one illconsidered freshman year fling — when Bruce and I hooked up, and I'd fooled around extensively with another half-dozen. I might've been a big girl, but I'd been reading Cosmopolitan since I was thirteen, and I knew my way around the various pieces of equipment. At least I'd never had any complaints. So I was experienced. ${ }^{52}$

Here Cannie's 'experience' is a matter of fact, described as the result of years of Cosmopolitan readings and 'fooling around' with various men, and underlines the character's playful approach to sex and intimacy. Similarly, in See Jane Date, Jane's friend Eloise is held up as a role model because she is thirty, single, and enjoys dating more than anything else:

Among the many things I loved about Eloise Manfred was that she was two years older than I was (the big three O), and didn't mind being single. In

${ }^{51}$ Senate, See Jane Date, p. 281.

${ }^{52}$ Weiner, Good in Bed, p. 22 
fact, she relished her freedom and the choices out there. She dated constantly. Younger men, older men, cute men, ugly men, muscle-men, short men, bald men, hot men. All nationalities and colors and professions. $^{53}$

Eloise's self-confident approach to the dating scene draws on a key concept in postfeminist media discourse and chick culture, that women have gained the right to a complicit, playful and liberated approach to sexuality. By saying that thirty-years-old Eloise is not bothered by being single, and furthermore she actually enjoys the freedom that her status grants her, the above passage disrupts romance's pivotal tenet of the stable union between man and woman. This concept is reiterated a few pages later, when Eloise's latest lover pressures her to spend more time together and she quickly dismisses him by claiming that she needs her own space ('He's just so clingy, you know? I like to have nights to myself'), to which Jane replies that she would never be able to act the same way. ${ }^{54}$

However, despite characters like Eloise, who assertively take control of their sexual life and keep cheesy romance at a distance, the genre's approach toward sentimental relationships remains ambiguous. In this respect, Rosalind Gill argues that while chick lit is certainly re-writing romance with regard to sex and relationships, in these novels 'married heterosexual monogamy' 55 is still ranking first among the many options available to women; in a similar vein, Whelehan comments that chick lit 'provides a post-feminist narrative of heterosex and romance [that] uneasily celebrates romance while anatomizing the ways in which romance makes dupes of perfectly rational single

\footnotetext{
53 Senate, See Jane Date, p. 15.

${ }^{54}$ Senate, See Jane Date, p. 81.

55 Rosalind Gill and Elena Herdieckerhoff, 'Rewriting the Romance. New Femininities in Chick Lit?', Feminist Media Studies, 6 (2006), 487-504 (p. 500).
} 
women' ${ }^{56}$ Finally, Tanja Modleski compares chick lit to popular romance novels and defines the former 'antiromantic romances' or 'novels of disillusionment', 57 as the romantic plot is often challenged, if not satirised, by a plethora of decidedly bad experiences. Likewise, for feminist cultural critic Teresa Ebert chick lit is 'the romance of postcontemporary cynical reason', because in these texts 'the whole idea of love as fulfilment' of popular romance is constantly kept at a distance and ironically rewritten by means of 'minimalist rhetoric' and 'bare realism' ${ }^{58}$ This is particularly true of Bushnell's Sex and the City, where romantic love is quickly and remarkably demystified: 'When was the last time you saw two people gazing into each other's eyes without thinking, Yeah, right?'. Shortly after, the fleeting nature of romance lays bare in Carrie's cynical words: 'Every time a man tells me he is a romantic, I want to scream [...] All it means is that a man has a romanticized view of you, and as soon as you become real and stop playing into his fantasy, he gets turned off. That's what makes romantics dangerous. Stay away, ${ }^{59}$

\subsubsection{Friendship}

If sentimental relationships are downplayed and demystified, friendship is often held up as a safe haven for (single) women. As Diane Negra pointed out in her discussion of HBO's Sex and the City, for example, the four characters rely on their friendship to challenge the dominant definition of family and romance ${ }^{60}$ in fact, more often than not

\footnotetext{
${ }^{56}$ Whelehan, The Feminist Bestseller, p. 186.

${ }^{57}$ Tania Modleski, Loving with a Vengeance: Mass-Produced Fantasies for Women, $2^{\text {nd }}$ edition (New York: Routledge, 2008), p. xxiv.

${ }^{58}$ Teresa L. Ebert, The Task of Cultural Critique (Urbana: University of Illinois Press, 2009), pp. 104106.

${ }^{59}$ Bushnell, Sex and the City, p. 2 and p. 7, respectively.

${ }^{60}$ Diane Negra, 'Quality Postfeminism? Sex and the Single Girl on HBO', Genders OnLine Journal 39
} 
friends provide the fun, stability and emotional fulfilment that seem to be lacking in heterosexual relationships. At the same time, however, friendship does not remain confined to an idyllic perfection: this is the case of Sushifor Beginners, where the protagonist Aishling discovers that Clodagh, her best friend, is cheating on her husband with Aishling's boyfriend. Surprisingly, it is not so much the cheating that leaves Aishling distraught, but the fact that Clodagh has gone against the protected and familial environment that their friendship had always provided:

She and Clodagh had been friends since they'd been five. Best friends. They'd lived through childhood, adolescence and adulthood together. They shared a common history and no one would know her the way Clodagh knew her. That sort of friendship is rare. ${ }^{61}$

The bond between the two women is called 'rare' and rendered as if they were siblings, twin sisters almost, and it is in this light that the audience is invited to assess Aishling's grief.

A further element to consider with regard to friendship in chick lit is the ubiquitous presence of at least one gay male friend. Often used as a means to infer the openmindedness of the (heterosexual) protagonists, who despise the conservative moral values of the society they live in, the friend is also the key to a different kind of bond across genders. As Bridget Jones's friend Tom ironically asserts, 'homosexuals and single women in their thirties have natural bonding: both being accustomed to disappoint their parents and being treated as freaks by society' ${ }^{62}$ The character's features include a sharp sense of humour, good taste in fashion and, above all, the (2004), [14] <http://www.genders.org/g39/g39_negra.html> [accessed 30 March 2008].

${ }^{61}$ Keyes, Sushi for Beginners, p. 558. In this respect, a cogent analysis of Keyes' chick lit, one of the most successful in the genre, is in Elena Pérez Serrano, 'Chick Lit and Marian Keyes: The Ideological Background of the Genre', in Working Papers on the Web, 13 (2009) <http://extra.shu.ac.uk/wpw/ chicklit/perezserrano.html> [accessed 15 December 2009].

${ }^{62}$ Fielding, Bridget Jones's Diary, p. 27. 
understanding of the dynamics of human relationships, a trait typically attributed to women. Indeed, it is not unusual for the protagonist and her gay friend to share intimate thoughts and compare opinions about men, especially when both have been disappointed by their respective partners and are in need of consolation. ${ }^{63}$ Lesbian characters however are far less present and are mostly depicted in the same terms as conventionally attractive straight women, either single or, more often, in relationships that mirror heteronormative behaviour. Not surprisingly, their storylines frequently revolve around issues of family and motherhood, the latter both biological and nonbiological. As we shall see, this narrative trope is present in Canevari and Fiume's Voglio un mondo rosa shokking, an Italian chick lit novel that I will discuss in depth later in this thesis. Interestingly, Good in Bed plays on this stereotypical representation of lesbian characters in popular culture when the protagonist reflects on her mother's lesbian lover, whom she does not like:

[I] sat there, picturing a more appropriate same-sex love: say, a chic film professor from UPenn, with tenure and a pixie haircut and interesting amber jewellery, who'd introduce us to independent film directors and take my mother to Cannes. Instead, my mother had fallen for Tanya, who was neither well-read nor chic, whose cinematic tastes ran toward the later works of Jerry Bruckheimer, and who didn't own a single piece of amber. ${ }^{64}$

Certainly ironic in purpose, the above passage falls short in countering the stereotype and in fact confirms chick lit's idea of lesbianism as fashionable and glamorous femininity. Not only could Tanya's exterior aspect, previously depicted as 'a tiny boiled pea of a woman [with] frizzy reddish hair and skin tanned the color and consistency of old leather', be more distant from feminine conventional beauty, but

\footnotetext{
${ }^{63}$ See also Baz Dreisinger, 'The Queen in Shining Armor', Journal of Popular Film \& Television, 28 (2000), 2-11.

${ }^{64}$ Weiner, Good in Bed, p. 192.
} 
also her lowbrow tastes and education are assessed against equally stereotyped images of high-class, sophisticated and well-educated lesbian women in mainstream popular culture. $^{65}$

\subsubsection{The urban context: locations and professions}

The chick lit canon also prescribes an urban context, usually a fashionable metropolis like London, Los Angeles or New York. The fictional representation of these iconic cities oscillates from stereotyped, pre-packaged backgrounds to genuine and lively metropolis that play a fundamental role in relation to the events narrated in the plot. Discussing British chick lit, Knowles for example reads the presence of easily identifiable London suburbs and locations not as a formulaic, name-dropping acknowledgment of the city but as an effective tool to create 'a very specific socioeconomic experience and background' for the characters. ${ }^{66}$ In fact, these locations become narrative spaces where, Knowles continues, 'the detail of urban living and the problems of formulating identity are concerned' (p. 37). Likewise, in Bushnell's Sex and the City New York, and specifically Manhattan, performs various strategic functions: on a formal level it is the thread that sews different narratives together, but it soon becomes a real co-protagonist of the story. Furthermore, it fleshes out discourses of social and cultural identity, as in the excerpt below:

There's Francis Ford Coppola at a table with his wife. There's an empty chair at Francis Ford Coppola's table. It's not just empty: It's alluringly, temptingly, tauntingly, provocatively empty. [...] And then, [...] Donovan

\footnotetext{
${ }^{65}$ The representation of the lesbian body in mainstream popular culture has been investigated in Ann M. Ciasullo, 'Making Her (In)Visible: Cultural Representations of Lesbianism and the Lesbian Body', Feminist Studies, 27, 3 (2001), 577-608. See also Rebecca Beirne, Lesbians in Television and Text after the Millennium (New York: Palgrave Macmillan, 2008).

${ }^{66}$ Joanne Knowles, 'Material Girls: Location and Economics in Chicklit Fiction, Or, How Singletons Finance Their Jimmy Choo Collections', Diegesis, 8 (2004), 36-41 (p. 37).
} 
Leitch sits down for a chat. Everyone in the room is immediately jealous. Pissed off. The energy of the room lurches violently. This is romance in New York. ${ }^{67}$

Iconic movie director Francis Ford Coppola and his glamorous presence in a restaurant, conventionally used to infer its place among the city's posh circles, are paired with emotions of desire and jealousy that reframe and cynically disrupt mainstream ideas of 'romance in New York'. ${ }^{68}$

The urban setting is also the ideal backdrop for characters that are largely careeroriented, offering endless possibilities for professional affirmation. In The Devil Wears Prada, for example, college graduate Andrea (Andy) Sachs moves to New York hoping to become a columnist for The New Yorker, but she finds an entry-level job in a prestigious fashion magazine instead and ends up working as junior assistant to the legendary and intimidating editor-in-chief Miranda Priestly. Harzewski notes that 'the city's frenetic activity parallels chick lit's fast-moving plots', ${ }^{69}$ and indeed here the workplace and career are the main backdrop against which the whole narrative develops, providing a commentary on the frustrations, anxieties and desires related to them. ${ }^{70}$ Allison Cole points out that 'Andy's job is a source of cultural capital for her, earning societal status all throughout New York City', ${ }^{71}$ yet after the initial enthusiasm Andy struggles to be someone other than she is; nevertheless she carries on with her

${ }^{67}$ Bushnell, Sex and the City, pp. 3-4.

${ }^{68}$ By contrast, the TV adaptation uses the appeal of the city in popular and media culture and indulges in the city's colourful landscape, transforming it into a visual and narrative space of romance where the four women move and live completely at ease. See Negra, 'Quality Postfeminism?'.

${ }^{69}$ Harzewski, Chick Lit and Postfeminism, p. 30.

${ }^{70}$ Elizabeth Hale, 'Long-Suffering Professional Females: The Case of Nanny Lit', in Chick Lit, ed. by Ferriss and Young, pp. 103-18.

${ }^{71}$ Allison Cole, 'Can't Afford the Manolos? Buy the Book! Chick Lit \& Contemporary Consumerism', Undergraduate Research Symposium, 2007, p. 20 <http://digitalcommons.colby.edu/ugrs/13> [accessed 4 February 2010]. 
job and the impossible tasks it demands, proving to be very good at it and even gaining unexpected praise from her boss Miranda:

In a move that was so fundamentally out of character for this woman on every level, [Miranda] placed her hand on top of the one I had resting on the seat between us and said, "You remind me of myself when I was your age." [I] wondered if this was the proudest or the most humiliating moment of my life. ${ }^{72}$

Although flattered by Miranda's words, Andy starts questioning the position and role she occupies in her entourage and eventually quits the prestigious job, in a gesture that reaffirms her own identity and values:

Fuck her for even thinking that I was anything like her. And most of all, fuck her for being right. What the hell was I standing here for, getting abused and belittled and humiliated by this joyless she-devil? So maybe, just maybe, I, too, could be sitting at this very same event thirty years from now, accompanied only by an assistant who loathes me, surrounded by armies of people who pretend they like me because they have to. ${ }^{73}$

Significantly, Andy's awakening happens when she fully understands her complicit participation in Miranda's manners and the power that such a position would grant her: as she angrily admits, 'fuck her for being right'.

A similar reasoning applies to Lisa in Sushi for Beginners, only in reverse. In this case, the loss of cultural capital and societal status affects a 'Miranda-like' editor who, instead of finally becoming the deputy editor of an important magazine in New York, is retrocessed to Dublin to work on the launch of a new women's monthly. A workaholic determined to climb the career ladder, Lisa has to build a new career from scratch and she succeeds at it, to the point that she is head-hunted by her company's biggest competitor in London, but the experience in Dublin has somehow changed her:

${ }^{72}$ Weisberger, The Devil Wears Prada, p. 338.
${ }^{73}$ Weisberger, The Devil Wears Prada, p. 341. 
[Lisa] realized she wasn't quite sure she had the stomach for editing a monthly gloss any more. Clambering up the greasy pole, humiliating others and taking credit for their work no longer held the appeal it once had [...] Once she'd been excited, fuelled even, by such a competitive environment. But not now, and at this realization she experienced panic - had she become a weakling, a sap, an also-ran? But she didn't feel weak. Just because there were some things she didn't want to do any more didn't mean she was weak, it just meant she was different.

Not too different, obviously, she acknowledged wryly: she still loved the shallowness of magazines. [...] So the obvious career move was to look for consultancy work. ${ }^{74}$

Unlike Andy, who was at the bottom end of the career ladder, Lisa had always felt at ease in the competitive and cynical environment of fashion magazines, and unlike Andy she does not walk away from it. Yet, despite their differences, what the two characters share is a new perception of work for upper and middle-class contemporary women: as Ebert points out in her compelling analysis of chick lit, the genre brings to the forefront how '[women] expect to work not simply at jobs but in careers that provide both meaning and economic security' ${ }^{75}$ For different reasons, at some point Lisa and Andy find themselves trapped in 'jobs' that provide a fair amount of economic security but lack meaning, and try to reassess their position in the workplace.

\subsubsection{Fashion and consumerism}

Finally, fashion and consumerism, particularly of name-brand items such as shoes, bags and clothes, are a fundamental chick lit feature epitomised by titles such as Confessions of a Shopaholic and The Devil Wears Prada. This is particularly evident in HBO's Sex and the City, where Carrie's obsession with designer shoes played a fundamental role in bringing into the limelight designers such as Manolo Blanhik and Jimmy Choo. Far from being limited to product placement techniques, the centrality of

\footnotetext{
${ }^{74}$ Keyes, Sushi for Beginners, pp. 542-43.

${ }^{75}$ Ebert, The Task of Cultural Critique, p. 111.
} 
fashion and consumer culture in the show has prompted scholars to investigate its narrative function. Jane Arthurs argues that the show allows both complicity with and critique of consumerism: on the one hand, a 'consumer lifestyle is presented not as a series of commodities to be bought but as an integrated lifestyle to be emulated'; on the other hand, however, it brings to the surface women's ambiguous 'complicity in the processes of commodification [as it underlines] narcissistic relation to the self, the production of fetishist and alienated sexual relations' ${ }^{76}$ In regard to fashion, Stella Bruzzi and Pamela Church Gibson investigate its innovative role as 'the fifth character' of the show, arguing that fashion and costume maintain 'a separate identity within the series' overall narrative': not only these items define and shape each character's personality, but they also perform independently from script and narrative, 'offering an alternative and potentially contrapuntal discursive strategy'. ${ }^{77}$

A similar view is held by James Annesley, who looks into Bushnell's original novel and argues that while 'the logo functions as the perfect way of delineating characters and defining their status', the use of brands plays a significant role inasmuch as it offers 'a much more critical account of the relationships between the women [Bushnell] describes and the consumer society they inhabit'. ${ }^{78}$ The cynical way Bushnell equates relationships with material transactions, alongside the deadpan humour and unadorned writing style she uses throughout the novel, plays on the pervasive infiltration of consumer culture in all areas of contemporary society, in line with the works of many other postmodern American novelists of the 1990s,

\footnotetext{
${ }^{76}$ Jane Arthurs, 'Sex and the City and Consumer Culture: Remediating Postfeminist Drama', Feminist Media Studies, 3 (2003), 83-98 (p. 90 and p. 95).

${ }^{77}$ Stella Bruzzi and Pamela Church Gibson, 'Fashion Is the Fifth Character: Fashion, Costume and Character in Sex and the City', in Reading Sex and the City, pp. 115-29 (p. 116 and p. 123, respectively). ${ }^{78}$ Annesley, Fictions of Globalization, p. 34.
} 
particularly Bret Easton Ellis (b. 1964) and Chuck Palahniuk (b. 1962). Each in their own way, Annesley argues, all these writers locate their characters 'in the world of brands and commodities', and they all use its distinctive language as a tool to investigate it. $^{79}$

It might be worth noting that, in the Italian context, the literary production of the 1990s giovani cannibali movement addressed brands and commodities in a similar way. ${ }^{80}$ As Stefania Lucamante and Elisabetta Mondello (among others) have noted, fashion brands, American movies and TV programs and songs became the cultural background of a young generation that grew up surrounded by them on all sides, and were used to portray each time alienation, sense of displacement, homologation, gender identity and social status. ${ }^{81}$ As I will discuss later in this thesis, a decade or so later Italian chick lit writers are addressing consumer culture in a way that is strongly indebted to these narratives of the 1990s and to contemporary postfeminist popular culture.

On a wider scale, however, fashion brands and other well-known goods such as Starbuck's coffee in chick lit texts cannot be separated from discourses on consumerism in postfeminist culture. Scholars of feminist studies have read the massive presence of fashion brands and the glorification of consumerism in light of 'commodity' or 'ludic' feminism, which domesticates the social and political agency of the historical movement into a neoliberal lifestyle of 'free-market individuality in

\footnotetext{
${ }^{79}$ Annesley, Fictions of Globalization, p. 32.

${ }^{80}$ For a comprehensive overview on the cannibali movement, see Stefania Lucamante, ed., Italian Pulp Fiction: The New Narrative of the Giovani Cannibali Writers (Madison: Fairleigh Dickinson University Press, 2001).

${ }^{81}$ Stefania Lucamante, 'Everyday Consumerism and Pornography "Above the Pulp Line", in Italian Pulp Fiction, ed. by Lucamante, pp. 98-134; Elisabetta Mondello, In principio fu Tondelli (Milan: Il Saggiatore, 2007), pp. 134-35.
} 
the name of empowering women'. ${ }^{82}$ In chick lit, shopping and consumerism convey a contradictory message that demands critical reading. In The Secret Dreamworld of a Shopaholic, for example, the protagonist Becky 'fully engages in culture of conspicuous consumption, fashioning and refashioning her identity by means of her label-driven purchase'. ${ }^{83}$ In other words, fashion items are for Becky a way to overcome emotional needs and social anxieties, albeit temporarily. A similar fleeting sense of belonging is evident in The Devil Wears Prada, when Andy needs to go to an important gala and is provided with a lavish gown and expensive accessories that would normally be out of her reach:

[...] a knockout floor-length black Oscar de la Renta number, provided kindly by Jeff, Closet maven and lover of all things feminine [...] The fashion assistant had already called in a pair of silver Manolos in my size, and someone in accessories had selected a flashy silver Judith Leiber evening bag with a long, clanking chain. [...] Stef was debating whether I should wear a chocker or a pendant, and Allison, the newly promoted beauty editor, was on the phone with her manicurist, who made office calls. $^{84}$

The dreamlike description of the outfit and the insistent name-dropping of top-end designer that underpin Andy's transformation may appear empowering, as she finally gains prestige and visibility, yet a closer look reveals that such transformation, like Cinderella's, is very much temporary. Caroline J. Smith's (2008) approach to chick lit, by contrast, focuses on the way in which the genre challenges and interfaces with consumer culture media, such as magazines, advice manuals, romantic comedy films

\footnotetext{
${ }^{82}$ Ebert, The Task of Cultural Critique, p. 81. On the debate around the commodification of feminism see also Robert Goldman, Deborah Heath, and Sharon L. Smith, 'Commodity Feminism', Critical Studies in Mass Communication, 8, (1991), 333-51; Angela McRobbie, 'Young Women and Consumer Culture', Cultural Studies, 22 (2008), 531-50; Jane Arthurs, 'Sex and the City and Consumer Culture', pp. 83-98.

${ }^{83}$ Jessica Lyn Van Slooten, 'Fashionably Indebted: Conspicuous Consumption, Fashion and Romance in Sophie Kinsella's Shopaholic Trilogy', in Chick Lit, ed. by Ferris and Young, pp. 219-38 (p. 219).

${ }^{84}$ Weisberger, The Devil Wears Prada, p. 256.
} 
and self-help books. From this perspective, Smith argues that chick lit authors 'create fictionalized instructional guides that problematise the ideologies offered by the advice manuals their characters read, ${ }^{85}$ assigning to their novels a critical approach to the contemporary consumer industry aimed at women. In doing so, Smith continues, by presenting characters who continually struggle with ideas of femininity, selfempowerment and consumption as presented in media culture, such as Fielding's Bridget Jones, chick lit texts expose these very same concepts and invite readers to look at them from various standpoints, negotiating their own relationship with them.

\subsection{Writing style and humour in chick lit}

Critics agree that chick lit's writing style revolves around two main elements: colloquial mode and humour. With regard to the former, Bridget Jones 's Diary can be considered almost an experimental novel, as the narration is carried out by means of journal entries, emails and memos that propel the audience not only into Bridget's mind, but also right into her chaotic world. Although there are no restrictions with regard to the point of view, following Fielding's example the majority of chick lit writers adopt a first-person narrative, and specifically the heroine's voice. Thirdperson narrative is also used but it is less frequent, perhaps due to the fact that such narrative choice makes the connection between reader and protagonist less immediate. ${ }^{86}$ In fact, chick lit is driven by the desire to establish a solid connection with the audience, and the predominance of first-person narrative in the genre is the

${ }^{85}$ Caroline J. Smith, Cosmopolitan Culture and Consumerism in Chick Lit (New York: Routledge, 2008), p. 6.

${ }^{86}$ However, Harzewski points out that in the last few years the saturation of the chick lit market has prompted editors to strongly discourage first-person narrative, which is now considered too much of a cliché: see Chick Lit and Postfeminism, p. 199. 
main indicator of this attempt, with the narrator coinciding with the female protagonist and thus inviting the reader to glimpse into her mind and empathise with her feelings.

This is exemplified in the following passage from The Devil Wears Prada:

I had a few seconds-peaceful seconds if one could overlook the angry honking and varied forms of the word 'fuck' being hurled at me from all directions-to pull off my Manolos and toss them into the passenger seat. There was nowhere to wipe my sweaty hands except for the suede Gucci pants that hugged my thighs and hips so tightly they'd both begun to tingle within minutes of my securing the final button. My fingers left wet streaks across the supple suede that swathed the tops of my now numb thighs. Attempting to drive this $\$ 84,000$ stick-shift convertible through the obstacle-fraught streets of midtown at lunchtime pretty much demanded that I smoke a cigarette. ${ }^{87}$

Here the narrating voice instantly throws readers into a frenzy of expensive shoes, designer clothes and frantic life pace. In the first sentence in particular, with the interpolate clauses positioned right at the beginning and its syncopated pattern, the protagonist of the novel Andy presents herself as young professional constantly in the line of fire and capable of dealing with extreme situation in a humorous manner. Moreover, the way in which Andy voices her downfalls and frustrations highlights another pivotal feature of chick lit's tone, that is, a captivating mixture of sympathy and laughter. Indeed, chick lit uses humour in order to enhance the reading experience and gain the audience's complicity. The successful combination of laughter and empathy arises from an observational humour that looks into the everyday life of the characters in order to generate a kind of involvement that operates on different levels. Firstly, chick lit's humour touches upon general issues that speak directly of contemporary women's reality; secondly, it is also referential, that is to say, these fictional representations are presented as genuinely applicable to the audience's own

${ }^{87}$ Weisberger, The Devil Wears Prada, p. 2. 
life; finally, on a more personal level, humour aims at generating alignment with the characters and situations presented in the narrative. Two examples may be helpful in highlighting how humour works in chick lit. In Sushi for Beginners, a novel told in the third person, the humorous tone takes the form of an underlying commentary on the characters' actions and thoughts:
Aishling woke at twelve on Sunday, feeling rested and only mildly hungover. She lay on the couch and smoked cigarettes until The Dukes of Hazzard finished. Then she went out and bought bread, orange juice, cigarettes and newspaper - one scurrilous rag and one broadsheet to cancel out the rag.
After gorging herself to the point of mild disgust on overblown stories of infidelity, she decided to tidy her flat. This mostly consisted of carrying about twenty crumb-strewn plates and half-empty glasses of water from the bedroom to the kitchen sink, picking up an empty tub of Haagen Daz from where it had rolled under the couch and opening the windows. She drew the line at polishing, but she sprayed Mr Sheen around the room and the smell instantly made her feel virtuous. ${ }^{88}$

From a narrative point of view, the omniscent third-person narrator puts the focus on Aishling guilty pleasures, from chain-smoking to reading 'rags', and on the exceptionally messy status of her apartment. From a stylistic perspective, the tone and choice of words give a lively picture of Aishling's personality that works by exaggeration: not only the 'rag' she 'gorges herself on' is 'scurrilous', but she also has 'twenty crumb-strewn plates' scattered throughout the bedroom, and her idea of cleaning the flat consists of palliative acts that make her feel 'virtuous' nonetheless. Yet, the final picture is not judgmental but rather benevolent, with a genuinely realistic tone that invites the reader to bond with the character.

${ }^{88}$ Keyes, Sushi for Beginners, p. 47. 
Likewise, in the case of Bridget Jones's Diary, a novel with a first-person narrator, humour is carried out directly by the protagonist through constant observations and reflections on her feelings and activities, as in the following excerpt:

[...] Wise people will say Daniel should love me just as I am, but I am a child of Cosmopolitan culture, have been traumatized by supermodels and too many quizzes and know that neither my personality nor my body is up to it if left to its own devices. I can't take the pressure. I am going to cancel and spend the evening eating doughnuts in a cardigan with egg on it. ${ }^{89}$

Comic in purpose, the passage is significant insomuch as it unravels the nature of chick lit's observational humour. By saying that she has been 'traumatized' by unattainable models of femininity presented in women's magazines, Bridget wittily addresses how they undermine women's confidence when it comes to body image and self-esteem; at the same time, by saying that if she 'can't take the pressure' she might just spend the night eating junk food and wearing dirty clothes, she underlines the overwhelming consequences of having to put up with these models nonetheless.

Not surprisingly, the use of humour and irony in chick lit, and more generally in postfeminist media culture, has attracted the attention of numerous critics, who have investigated its role in simultaneously confirming and subverting discourses of normative femininity, consumerism, and romance. Whelehan defines chick lit an 'anxious genre' and suggests that its combination of laughter and empathy is rooted in the 'tension between the self-deprecating humour [and] the more serious implications of the issues raised' ${ }^{90}$ significant as it is, Whelehan continues, this tension remains however mostly unresolved, accounting for the 'anxiety' that permeates the genre. In the passage quoted above, for example, Bridget knows that men should love her 'just

\footnotetext{
${ }^{89}$ Fielding, Bridget Jones's Diary, p. 59.

${ }^{90}$ Whelehan, The Feminist Bestseller, p. 214.
} 
how she is', yet this knowledge does not help her when faced with the dictates of 'Cosmopolitan culture', as she finds herself incapable of overcoming them. In this respect, we are reminded of Angela McRobbie, who, in her work on postfeminist popular culture, maintains that postfeminist popular culture has somehow erased critique 'on the basis of the distance entailed in the ironic experience': ${ }^{91}$ ironic distance, in McRobbie's view, is ultimately ineffectual because it operates as a form of containment, one that normalises 'post-feminist gender anxieties'.92 ${ }^{92}$ imilarly, Rosalind Gill discusses the genre's self-reflexivity and while she acknowledges that 'irony and knowingness' may supply women with an assertive tool to keep at a distance the pervasive demands of media culture, ${ }^{93}$ she argues that because it is often a self-reflexive type of irony, it endorses the same stereotypes that it is supposed to critique. Therefore, while on the one hand irony and humour in chick lit succeed in underscoring 'contradictory postfeminist discourses' related to beauty, consumerism and femininity, on the other hand they often fall short in challenging them, as their remain confined in a self-contained 'language of individualism'. 94

\subsection{Chick lit's paratextual elements}

The physical properties of a book are important aspect of any textual production, not only from the commercial point of view, but also from the literary one. Thomas $\mathrm{J}$. Roberts (1990), for example, suggests that 'a book is an object with physical properties that tell us what it is, cue our reading, and - sometimes - please and amuse us in their

\footnotetext{
91 Angela McRobbie, 'Post-Feminism and Popular Culture', Feminist Media Studies, 4 (2004), 255-64 (p. 263).

92 McRobbie, 'Post-Feminism and Popular Culture', p. 262.

${ }^{93}$ Rosalind Gill, Gender and the Media (Cambridge, Malden: Polity Press, 2007), p. 257 and p. 266.

${ }^{94}$ Gill and Herdieckerhoff, 'Rewriting the Romance', p. 500.
} 
own right' ${ }^{95}$ In order to highlight the importance of the physical properties of chick lit novels, I turn to Gérard Genette's pivotal concept of literary 'paratext', that is to say, the spatial frame that surrounds the text itself. In Genette's words, the paratextual elements 'surround [the text] and prolong it, precisely in order to present it, in the usual sense of this verb, but also in its strongest meaning: to make it present, to assure its presence to the world, its "reception" and its consumption, in the form, nowadays at least, of a book' ${ }^{96}$ Genette delineates two categories of paratext, namely 'peritext' and 'epitext', whose relationship with the text lies respectively in the space of the book itself or outside it. Peritextual elements are therefore the author's name, book's title, cover, colophon, title-page, epigraphs and dedications, while epitextual elements are located outside the book and refer to interviews with the author, journal articles and so forth.

Referring to Genette's terminology, I want to focus now on chick lit's peritext, as I consider it to be of great relevance in identifying a popular genre. In doing so, I will take into consideration some of the peritextual elements that help to define chick lit as a genre; in particular, I am going to consider the cover and the title as the most representative paratextual elements. Indeed, in their attempt to either launch a novel or establish a new narrative genre, publishers emphasise the physical properties of the book; particularly, the cover acts as a sort of business card: it is the public face of the book. As a strategic element, covers are chosen carefully because they communicate the nature of the book, often regardless of its real content. According to Genette, 'simply the color of the paper chosen for the cover can strongly indicate a type of

${ }^{95}$ Thomas J. Roberts, An Aesthetics of Junk Fiction (Athens: University of Georgia Press, 1990), p. 248. ${ }^{96}$ Gérard Genette, Paratexts. Thresholds of Interpretation (Cambridge: Cambridge University Press, 1997), p. 1. 
book', ${ }^{97}$ and indeed Italian detective fiction is called romanzo giallo because of the yellow cover chosen in 1929 for the first imprint dedicated to the genre; likewise, the romanzo rosa (popular romance) owes its name to the pink cover and rose on the jacket of the early 1920s romance series La Biblioteca delle Signorine, as I will explain more in detail in the next chapter.

In this context, chick lit covers can provide a useful case study, because such books are strongly identified with and marketed by their covers. As pointed out by Harzewski, the marketing strategy behind chick lit covers not only addresses 'the urban young professionals demographic [...] reluctant to purchase a romance paperback with a clinch cover', but it also plays on the 'penchant for designer commodities ${ }^{98}$ promoted in women's magazines. Thus they usually show a background in bright colours and a title written in fancy lettering; other typical elements, such as pictures or illustrations, are in a cartoon style and may display shoes, cocktail glasses, and/or the silhouette of a young woman. Over the last ten years these covers have established a strong and familiar brand for popular fiction directed at women, one that pairs lightweight readings together with a lifestyle based on basic tenets of postfeminist media culture, such as the freedom to be feminine and to enjoy consumer power. With regard to the latter, Harzewski highlights how for many commentators these very distinct visual features have borrowed one too many traits from advertising, which in turn have prompted a connection between their 'fashion-conscious exteriors' and the allegedly 'inferior literature' to which they belong, in spite of the genre's contents and

\footnotetext{
${ }^{97}$ Genette, Paratexts, p. 24.

${ }^{98}$ Harzewski, Chick Lit and Postfeminism, p. 47.
} 
evolution. ${ }^{99}$ In fact, the function of cover design is not limited to sustaining the identification and placement of new genres in the market, but it also outlines the writer's place in or outside the genre. As Squires argues, 'branding delivered through cover design can be crucial in the establishment of the writer's oeuvre, rather than a perception of their work as a collection of disparate titles - [contributing] to the author's (potential) canonisation'. ${ }^{100}$ As such, Squires continues, brand images 'work towards creating associations in readers' minds which may or may not be related to formal similarities in texts', ${ }^{101}$ and this is particularly true in the case of Italian chick lit novels, as I shall discuss in Chapters 2 and 3.

Genette also investigates the role of title in placing books into the space of the reader, proposing four different functions: designative, descriptive, connotative and tempting. ${ }^{102}$ The designating function refers to the identification of the book, that is to say, the title is 'the name' of the book; the descriptive function has to do with its content (such as Bridget Jones's Diary and The Secret Dreamworld of a Shopaholic); the connotative relates to the style of the title; seductive refers to what a title should (or should not) suggest to the reader in relation to their interpretation of the book: as Umberto Eco reiterates, the title is always a 'key to interpretation'. ${ }^{103}$ In this respect, chick lit titles rely mostly on the descriptive and seductive function, the latter rendered through ironic and displacing undertones that are the genre's trademark and indeed one of its most significant keys to interpretation. This is particularly evident in titles such

\footnotetext{
${ }^{99}$ Harzewski, Chick Lit and Postfeminism, p. 49.

100 Squires, Marketing Literature, p. 88.

${ }^{101}$ Squires, Marketing Literature, p. 89. Further perspectives on book covers and popular fiction, an intriguing topic that would deserve a much lengthier analysis, see Nicole Matthews and Nickianne Moody, Judging a Book By Its Cover: Fans, Publishers, Designers and the Marketing of Fiction (Aldershot and Burlington: Ashgate, 2007).

${ }^{102}$ Genette, Paratexts, pp. 89-93.

${ }^{103}$ Umberto Eco, Postscript to The Name of the Rose (San Diego: Harcourt Brace Jovanovich, 1984), p. 2.
} 
as The Secret Dreamworld of a Shopaholic, The Devil Wears Prada and Good in Bed, and the same approach is consistent with the Italian novels, which present descriptive and seductive titles such as Aspirapolvere di stelle, Valentina compra tutto and L'amore non fa per me, among others.

In conclusion, chick lit is tightly bonded to its paratext: at the very beginning, it presented the new genre and made it present to popular fiction; today, when the genre is successfully part of commercial popular fiction, its paratext still plays a significant role in keeping it firmly in the marketplace. In other words, it worked toward the creation of a 'genre fashion' that has become 'a way of configuring genre distinctions' ${ }^{104}$ Finally, since the genre has expanded into the international market, the function of the paratext as a threshold investigated by Genette facilitates not only its reception and consumption, but also its translation in a wider sense, as I shall discuss in greater detail in Chapters 2 and 3 with regard to the first chick lit novels produced in Italy.

\subsection{Chick lit on the literary stage}

In the course of this chapter I have pointed out how chick lit has attracted the attention of a number of scholars from feminist and media studies, and particularly of those investigating postfeminist popular and media culture, but far less from those interested in literary studies. Indeed, in 2001 chick lit novels were dismissed as 'froth' and 'instantly forgettable' by critically acclaimed authors such as Beryl Bainbridge and Doris Lessing; in 2003, journalist Anna Weinberg reassessed the genre and while she greeted early works such as Bridget Jones's Diary as 'innovative postfeminist

${ }^{104}$ Squires, Marketing Literature, pp. 158-60. 
writing, ${ }^{105}$ she saw the subsequent, repetitive production as a marketing ploy threatening the quality of women's writing and reading, nothing more than a series of bland variations on the same inconsequential story. The literary value of chick lit is typically rejected because of its commercial nature, which literary critics dismiss as a despicable mixture of poor writing, standard characters and predictable plots. In this respect, Joanne Knowles has given valuable insight to the conflicting 'meta-industry of chick lit commentary' that flourished around the genre since its debut on the literary stage, arguing that it is a criticism that still carries out 'historically established notions and anxieties about women's reading and writing habits'. ${ }^{106}$ Knowles rightly notes that while the literary establishment turns down the genre on the grounds of its lack of authorship and above all its purely escapist nature, scholars in feminist studies are no less trenchant in their criticism toward the genre, either because of the subject matter (too mundane) or the thriving success in the marketplace (too recreational), all of which are seen as a threat to the 'gravitas of realism' that women's writing should endeavour. $^{107}$

Nonetheless, chick lit has become a challenging field of literary enquiry in its own right, with critics discussing to what extent the genre born out of the Bridget Jones's Diary could be considered a genuine form of women's fiction. Within feminist criticism, Ruth Page has investigated Fielding's novel in light of feminist narratology and stylistics, combining theoretical and textual analysis to perform a 'genderconscious interpretation of the text'. In particular, Page focuses on the 'open-

\footnotetext{
${ }^{105}$ Anna Weinberg, 'She's Come Undone: Chick Lit Was Supposed To Be the Bright Light of Postfeminist Writing. What Happened?' Book, July-August 2003, pp. 47-49.

${ }^{106}$ Joanne Knowles, "'Our foes are almost as many as our readers": Debating the worth of women's reading and writing - the case of chick-lit', Popular Narrative Media, 1 (2008), 217-31 (pp. 217-19).

${ }^{107}$ Knowles, “'Our foes are almost as many as our readers"”, pp. 222-26.
} 
endedness' of the novel, a feature commonly used in feminist narrative that invokes resistance to a patriarchal system of values, and investigates its complex relationship with self-help discourses that undermine women's agency. ${ }^{108}$ Similarly, Leah Guenther reflects on Bridget Jones's Diary language and style as a 'new feminist confession', suggesting that the first-person female narrative adopted by Fielding, alongside irony and humour, has fostered the creation of a new female community of readers and writers based on equality. ${ }^{109}$

Significant attempts to investigate the position of chick lit on the literary stage have been made by Imelda Whelehan, Juliette Wells, Cecilia Konchar Farr, and Stephanie Harzewski. Whelehan's study looks at women's popular fiction and its relationship to feminism, linking chick lit to a wide range of American 'feminist bestsellers' of the late 1960s and 1970s and noting how they made use of popular fiction to reach a wider readership and spread 'core feminist ideas simply and effectively'. ${ }^{110}$ Whelehan points out that these popular consciousness-raising novels, among which she includes Erica Jong's Fear of Flying (1974) and Rita Mae Brown's Rubyfruit Jungle (1973), were instrumental in capturing the cultural context of their time, highlighting the confessional writing as an innovative strategy through which they addressed and discussed 'themes and issues at the forefront of women's lives'. ${ }^{111}$ Yet, these novels were often dismissed by feminist critics for being too self-indulgent and, most importantly, commercially-minded, thus lacking in both literary sophistication and

\footnotetext{
${ }^{108}$ Ruth Page, 'Bridget Jones's Diary and Feminist Narratology', in Contemporary Stylistics, ed. by Marina Lambrou and Peter Stockwell (London, New York: Continuum, 2007), pp. 93-105.

${ }^{109}$ Leah Guenther, 'Bridget Jones's Diary: Confessing Post-feminism', in Modern Confessional Writing: New Critical Essays, ed. by Jo Gill (New York: Routledge, 2006), pp. 84-99.

${ }^{110}$ Whelehan, The Feminist Bestseller, p. 3.

${ }^{111}$ Whelehan, The Feminist Bestseller, p. 5.
} 
political commitment. As Whelehan turns her analysis to chick lit novels, she notes the same harsh criticism at work, one that considers the genre not worthy of literary investigation on the ground of triviality and mundane navel-gazing. Like the feminist bestseller, however, which chick lit follows in sharing the confessional female voice as well as the humorous tone, the genre must be read against the contemporary sociocultural context and analysed as a kind of popular fiction that openly (and successfully) speaks to a new generation of women about the complexities of their lives. The alleged self-reflexivity that permeates these texts, in fact, underscores shared issues across generations of women. While Whelehan concedes that chick lit holds little to no 'radical potential', since the readership it addresses is (mostly) confined to white, middle-class, heterosexual women, she also underlines the anxieties and tensions that incessantly ripple through this homogeneous surface, revealing a 'fairly substantial critique of contemporary women's lives' ${ }^{112}$

Harzewski and Wells, on their part, look specifically at the genre's literary genealogy and while they both investigate the overt relationship that chick lit has established with literary classics such as the works of Jane Austen, Charlotte Brontë and Edith Wharton, they reach quite different conclusions. Wells acknowledges that chick lit has roots 'in the history of women's writing', yet she maintains that when compared to its predecessors it cannot be defined 'literature' but, rather, 'fiction'. 113 Chick lit novels certainly offer a social commentary on customs and gender relationships, helped in this by a rather original use of satiric language and colloquial

\footnotetext{
${ }^{112}$ Whelehan, The Feminist Bestseller, p. 218 and p. 184 respectively.

${ }^{113}$ Juliette Wells, 'Mothers of Chick Lit? Women writers, Readers and Literary History', in Chick Lit, ed. by Ferriss and Young, pp. 47-70 (p. 49).
} 
slang, ${ }^{114}$ but while Austen and Wharton's writing shaped a multilayered satire of the social and cultural traditions of their times, in chick lit the satire struggles to go beyond the surface, offering an empathetic reading that simply reflects the society of which they are a product: 'the novels themselves skirt truly challenging territory, whether social or literary'. ${ }^{115}$ Like Wells, Harzewski acknowledges chick lit's shortcomings, particularly its detachment from politics and its unabashed focus on glamour and lifestyle; unlike Wells, however, she sees chick lit's 'high readability' as the distinctive feature that allows the genre a place in the literary scene. By defining chick lit a 'subset of women's general fiction and humorous literature', ${ }^{116}$ Harzewski carves a niche for the genre and inscribes it into the tradition of the novel of manners, arguing that the genre should be read as 'a new incarnation of the courtship novel'. ${ }^{117}$ Indeed, by addressing and rewriting some of the tenets of Austen and Wharton's works, specifically those related to class and money, chick lit novels reflect and comment on 'contemporary courtship behavior, dress, and social motives'; as such, Harzewski concludes, chick lit could be understood as 'an ethnographic report on a new dating like the novel of manners, but updated to the climate of feminism'. ${ }^{118}$

The complexity of the current debate around the literary merits of chick lit, however, is perhaps best captured in Konchar Farr's It Was Chick lit All Along (2009) and Jim Collins's Bring On the Books for Everybody (2010). Konchar Farr's intriguing analysis takes chick lit out of its generic and gendered niche and points it toward the history of the novel. Indeed, she invites both cultural and literary critics to be less concerned with

\footnotetext{
${ }^{114}$ Wells, Mothers of Chik Lit?, p. 64.

${ }^{115}$ Wells, Mothers of Chik Lit?, p. 68.

${ }^{116}$ Harzewski, Chick Lit and Postfeminism, p. 185.

117 Harzewski, Chick Lit and Postfeminism, pp. 3-4.

${ }^{118}$ Harzewski, Chick Lit and Postfeminism, p. 4.
} 
the 'gendering' of the genre and to study it as part of a broad literary tradition, in what she considers 'a fascinating foray into the ongoing literary historical conversation about the novel'. ${ }^{119}$ As Konchar Farr goes back to the rise of the novel as a genre, she focuses on the 'democratic, material, and feminine qualities' of the novel that scholarly aesthetic codifications have subsequently side-tracked as gendered qualities, such as the author's tendency to address the reader, the entertaining nature, the lively characters and sympathetic connection they foster, particularly the significant role the novel as a genre held in the marketplace. ${ }^{120}$ Thus instead of assessing these qualities solely from a sociocultural perspective or curtailing them as women's interests and reading habits, Konchar Farr calls for a new literary criticism that assigns aesthetic value to them, one that would enrich with accuracy and insight the study of the novel and, consequently, of chick lit as well. ${ }^{121}$

Collins takes up some of Konchar Farr's observations and investigates the emergence of 'popular literary culture' within the contemporary literary, cultural, and social landscape as a new field where 'mass media and literary reading are not mutually opposed but interdependent experiences'. ${ }^{122}$ In analysing popular literary fiction, Collins outlines a number of novels that he defines 'Post-Literary', as they seek to negotiate cultural authority and audience participation through a complex web of intertextual references. ${ }^{123}$ The concept that Collins proposes is that in these books, among which he includes many chick lit bestsellers, the line between literary tradition

${ }^{119}$ Cecilia Konchar Farr, 'It Was Chick Lit All Along', in You've Come a Long Way, Baby: Women, Politics, and Popular Culture, ed. by Lilly J. Goren (Lexington: University Press of Kentucky, 2009), pp. 201-14 (pp. 211-12).

${ }^{120}$ Konchar Farr, p. 203.

${ }^{121}$ Konchar Farr, pp. 210-11.

${ }^{122}$ Jim Collins, Bring on the Books for Everybody: How Literary Culture Became Popular Culture (Durham: Duke University Press, 2010), p. 17.

${ }^{123}$ Collins, Bring on the Books for Everybody, p. 187. 
and popular culture blurs into a kind of quality fiction where 'dismissal of' and 'affiliation with' literary culture go hand in hand. ${ }^{124}$ Indeed, all these novels claim canonical literary fiction (particularly the novel of manners) as their major source of inspiration, which they however use not as formal or stylistic model but rather as a tool for addressing and negotiating 'the complexities of contemporary desire'. ${ }^{125}$ Drawing on Bourdieu's notions of social, economic and cultural capital, Collins reframes the continuity between the novel of manners and chick lit proposed by Harzewski against the backdrop of consumer and multimedia culture, all of which have been pivotal in the displacement of the traditional boundaries of financial and cultural capital. Because chick lit is aimed at middle-class, financially independent and educated female readers, the borrowing of canonical literary texts by women such as Wharton and Austen is less an arbitrary attempt to elevate women's popular fiction, as Wells suggested, than the expression of a shared knowledge between writers and audience that promotes both individual and social reading through a complex web of various media products. ${ }^{126}$

\subsection{Conclusion}

Initially studied within women's fiction and popular romance, chick lit has quickly branched out into other fields, prompting an intense debate on its merits, qualities and shortcomings. As we have seen, since their debut in the mid-1990s, chick lit texts have encompassed multifaceted issues and are now rife with contradictions, being at once a marketing ploy, a 'post-literary' and postfeminist genre, a genuine attempt at

\footnotetext{
${ }^{124}$ Collins, Bring on the Books for Everybody, p. 191.

125 Collins, Bring on the Books for Everybody, p. 188.

${ }^{126}$ Collins, Bring on the Books for Everybody, p. 187-91.
} 
addressing the experiences and issues of contemporary women in industrialised Western countries and a commentary on feminism and its place and meaning in today's society. Either way, it is fair to say that in the last decade chick lit paved new ground for popular fiction, having crossed geographical and linguistic boundaries and provided material for local variations that address different socio-cultural needs and values. In the next chapter, I look firstly at chick lit's performance on the international stage and then focus on the first Italian adaptations of the genre, examining how, if at all, they have followed the genre conventions, as well as the outcome of such connection in terms of style and language. As we shall see, these novels speak to the Italian audience's specific cultural and social identity while simultaneously trying to reproduce the mainstream appeal of the original model through key themes such as sexuality, femininity and financial independence. 


\section{CHAPTER 2 - Chick lit for the Italian marketplace? Toward a local production}

\subsection{Introduction}

In the previous chapter, I examined the chick lit novels in English that are generally considered the key texts in the creation and development of the genre. In this chapter, I assess the initial attempts at producing an Italian chick lit, looking at the Italian novels published during the early 2000s that openly identify with some of the Anglophone models. My focus is on the ways these Italian novels perform the original canon, as I situate Italian chick lit within the narrative codes and norms of the genre. I will conduct a close analysis of three Italian novels, Alessandra Casella's Un anno di Gloria (2001), Carlotta Magnanini's Valentina compra tutto (2002) and Camilla Vittorini's Qualcosa bolle in città (2004), ${ }^{1}$ offering a reading of the textual and paratextual elements that assesses their relationship with original chick lit. In doing so, I turn to the studies of Giuseppe Petronio on popular fiction, who maintains that genres should be assessed internally, that is, in relation to their own rules rather than abstract literary values: 'la distinzione di valore [...] non passa tra l'uno e l'altro genere, ma all'interno di ciascun genere e pertanto caratterizza opere e non generi'. ${ }^{2}$ In other words, critics and scholars should evaluate not the genre but the works that participate in its tradition and development, looking at how each one of them performs in practice.

\footnotetext{
${ }^{1}$ Alessandra Casella, Un anno di Gloria (Milan: Salani, 2001); Carlotta Magnanini, Valentina compra tutto: Una guida allo shopping metropolitano a Roma, Parigi, Londra (Reggio Emilia: Aliberti, 2002); Camilla Vittorini, Qualcosa bolle in città (Milan: Red Dress Ink, 2004).

${ }^{2}$ Giuseppe Petronio, Letteratura di massa. Letteratura di consumo (Roma-Bari: Laterza, 1979), p. xxxiii. See also Petronio, Critica e società di massa (Trieste: LINT, 1983).
} 
Petronio's approach resonates with Anne Cranny-Francis's research on popular culture, particularly where she refers to the concept of intertextuality developed by Russian theorist Mikhail Bakhtin. ${ }^{3}$ Texts entertain an ongoing dialogue with each other and the audience in order to create meaning, both internally and externally; this, however, does not mean that intertextuality simply addresses the similarities across texts. In CrannyFrancis's view, intertextual analysis brings to light 'the ways in which a novel differs from other examples of the same genre in terms of the many textual strategies and semantic preoccupations which define the genre'. ${ }^{4}$ As such, intertextuality becomes a powerful tool for the investigation of the textual strategies and conventions at work in a genre, showing how they are constantly rearranged, transformed and reinterpreted.

Before looking at Italian chick lit and its intertextual relationship with the Anglophone production, the first part of this chapter offers a brief outline of romanzo rosa (Italian popular romance fiction, often shortened to rosa). Deeply rooted in Italy's cultural, social and literary landscape since the nineteenth century, rosa's unique features cannot be overlooked when discussing the production of women's popular fiction in today's Italy. In fact, rosa's legacy always looms in the background, fostering an intertextual discourse that operates on many levels between the old texts and the new ones, a topic that I will address throughout this thesis and particularly in Chapter 5.

\subsection{Italian popular romance: romanzo rosa and its evolution}

In approaching the romanzo rosa, the first thing to note is that, unlike other kinds of popular fiction such as detective and science fiction, romance is a genre that has never

\footnotetext{
${ }^{3}$ Anne Cranny-Francis, Popular Culture (Geelong: Deakin University Press, 1994), p. 18.

${ }^{4}$ Cranny-Francis, Popular Culture, p. 19.
} 
been taken seriously by Italian literary critics. As Antonia Arslan and Maria Pia Pozzato maintain, '[o]gni discorso critico sulla letteratura rosa è contraddistinto da un certo margine di imbarazzo più o meno evidente. $[\mathrm{N}]$ on si tratta solo di una manifestazione screditata a livello di stile e di qualità del fruitore, ma anche di un discorso sul sentimento e sul sesso che nella nostra cultura costituisce già di per sé un problema'. As we have seen in the previous chapter, the devaluation of novels based on gendered criteria recurs over time and across literary studies, and Italian popular romance is no exception. Together with the claims made against the genre in relation to its allegedly simplistic or banal aesthetic features (from its subject matter to the predictable narrative formulas it deploys) Arslan and Pozzato note how, in the Italian context, discourses on female desire and sexuality have always received a more problematic approach when compared to other Western countries, thus adding layers of misconception and antagonism toward a genre that largely revolves around these subjects.

I shall return to this matter later; for now I will take a look at the history of the romanzo rosa, which Eugenia Roccella defines as a modern literary product, the result of crucial changes in the publishing market that took place during the early twentieth century:

Il romanzo rosa è, per più motivi, un tipico prodotto moderno. Lo è sul piano editoriale, su quello dei contenuti, del linguaggio, del modello narrativo, del rapporto tra autrici e pubblico. È nel primo dopoguerra che inizia il processo di diffusione di massa della cultura e della lettura. Negli anni Venti iniziano ad apparire le prime collane di libri rosa, e si diversificano le linee editoriali. [...] Il romanzo rosa è figlio dell'organizzazione novecentesca dell'editoria e della

\footnotetext{
${ }^{5}$ Antonia Arslan, and Maria Pia Pozzato, 'Il rosa', in Letteratura italiana. Storia e geografia, III, ed. by Alberto Asor Rosa (Turin: Einaudi, 1989), pp. 1027-46 (p. 1027). On the intersection between genres and genders in a wider context, see also Le prospettive di genere: Discipline, soglie e confini, ed. by Raffaella Baccolini (Bologna: Bononia University Press, 2005).
} 
cultura, e frutto di quella specializzazione dei settori che a lungo andare avrebbe portato alla serialità. ${ }^{6}$

Indeed, during the interwar years publishing and reading practices in Italy changed dramatically, reflecting social and political transformations. The literacy programme promoted after the unification of the country in the late nineteenth century was meant to deal with contrasting realities, with a significant increase in the literate population side by side with large areas of illiteracy. In the early 1920s, the development of a modern economy, particularly in Northern Italy, led to the rapid growth of a literate middle class that, along with economic wellbeing, was seeking social and cultural recognition. It was towards the needs of this emerging group that the publishing industry, in deep financial trouble after World War I, directed its efforts. Following a trend already practiced by other countries, such as the United Kingdom and America, the editorial strategy focused on the popular market. Popular, in this context, meant first and foremost commercially profitable, but it also addressed a more varied audience, one that was not limited anymore to academics and/or educated readers. ${ }^{7}$ Publishers isolated different targets based on factual data such as age and gender as well as potential interests, and started to produce texts that the target readerships would find both enjoyable and rewarding. As Spinazzola explains, ‘[i generi si differenziano] in base alla scelta di un determinato tipo di lettore quale destinatario privilegiato. Il discrimine tuttavia non è più o non è soltanto socioculturale [ma anche] di oggettività anagrafica, come il sesso o l'età, o di disposizione psicologica' ${ }^{8}$ It is in

\footnotetext{
${ }^{6}$ Eugenia Roccella, La letteratura rosa (Rome: Editori Riuniti, 1998), pp. 31-33.

${ }^{7}$ This overview of the rise of the Italian publishing industry after World War I is based on Giovanni Ragone, 'Editoria, letteratura e comunicazione', in Letteratura italiana. Storia e geografia, III, ed. by Asor Rosa, pp. 1047-67; Vittorio Spinazzola, La modernità letteraria (Milan: Net, 2005), pp. 68-69.

${ }^{8}$ Spinazzola, La modernità letteraria, p. 211.
} 
this context that genres flourished, and the romanzo rosa established itself as the one written by women, for women, about women: 'Perché si possa parlare di narrativa rosa occorre che l'autrice [...] dedichi le sue opere di personaggi muliebri a un pubblico specifico, fatto tutto e solo di donne'. ${ }^{9}$

Before exploring this further, a brief detour back into the nineteenth century is required, particularly to the works of Carolina Invernizio (1851-1916), considered by many critics the precursor of rosa writing. Inscribed in the romanzo d'appendice or feuilleton tradition (a popular genre of serial writings published in periodicals that originated in England and France in the late nineteenth century), Invernizio's rich production encompasses more than 100 novels in which romance, gothic and horror themes combine into passionate plots. Critics have analysed Invernizio's works extensively, investigating her style, language and the innovative roles women characters played in her production. ${ }^{10}$ Umberto Eco in particular has identified in Invernizio's novels three 'extraordinary' elements that were to influence subsequent rosa writers: the focus on a broad spectrum of characters and social classes, reflecting the demographics of her readership; the creation of her own narrative language, which refused refinement and aimed at catching the reader's attention through conventional vocabulary and a recognisable style; a woman (or group of women) as the 'agente risolutore', that is, the driving force of the story. ${ }^{11}$ Eco draws attention to the latter as quite innovative in terms of the historical development of the popular novel, but

\footnotetext{
${ }^{9}$ Spinazzola, La modernità letteraria, p. 212.

${ }^{10}$ A good analysis of Invernizio's place and role in the Italian literary landscape can be found in Anna Laura Lepschy, 'The popular novel, 1850-1920', in A History of Women's Writing in Italy, ed. by Letizia Panizza and Sharon Wood (Cambridge; New York: Cambridge University Press, 2000), pp. 17789. See also Remo Ceserani and Elena Salibra, 'Popular Literature in Nineteenth-Century Italy: Letteratura amena', Canadian Review of Comparative Literature, 9 (1982), 361-82.

${ }^{11}$ Umberto Eco, 'Tre donne intorno al cor...', in Umberto Eco, and others, Invernizio, Serao, Liala (Florence: La Nuova Italia, 1979), pp. 3-27 (pp. 22-23).
} 
refuses to see it as an expression of the empowerment of women in society as well. Although Invernizio herself had publicly voiced concerns about the miserable conditions of working-class women, Eco claims that Invernizio's female characters embody the 'semiotica del decoro', that is to say, they are a reflection of a culture in which a woman's exclusive duty was to guard the stability and respectability of the family as well as conform to traditional social rules. As soon as the proper order and mores are restored (typically by the end of the novel), the female protagonist is reappraised within the boundaries of the domestic place.

Substantially agreeing with Eco's analysis, Eugenia Roccella focuses on the centrality of women as a "matriarcato narrativo' 12 and considers this to be both Invernizio's most original feature and her main limit: on the one hand, her heroines occupy a predominant role in the sequence of events, and the situations they are forced to deal with, from assuming false identities to taking revenge for wrongs done to their families, are quite original in the late nineteenth-century literary landscape. On the other hand, Roccella points out that these innovative elements rely on a very limited perspective, that is, the 'onnipotenza materna' ${ }^{13}$. Indeed, in Invernizio's novels the only power a woman seems to possess is motherhood; as such, her place in the novel as 'agente risolutore' revolves around being (or wanting to be) a mother and is almost exclusively defined by it, a concept to which I shall return later in this thesis.

The rosa as a specific genre aimed at a specific public develops further in the early 1920s with publisher Salani's 'La Biblioteca delle Signorine', a series dedicated to an upper-middle class young female readership featuring sentimental stories with edifying

\footnotetext{
${ }^{12}$ Roccella, La letteratura rosa, p. 19.

${ }^{13}$ Roccella, La letteratura rosa, p. 21.
} 
and conservative endings. ${ }^{14}$ Along with the occasional Italian author, the novels were mainly translations of English and French works, notably those by Delly, Baroness Orczy and Elinor Glyn, with contents that emphasised young and humble heroines, charismatic and dominant heroes, turns of fortune and domestic scenes. ${ }^{15}$ As these novels were intended to have an educational purpose for young women, female characters reflected the binary opposition between 'good' and 'evil', that is, those who conformed to appropriate moral and social codes of femininity of the time and were awarded the happy ending, and those who failed at it and were punished instead, quite often with death. The success of the series prompted a few years later a reprint of the books under a new name, 'I Romanzi della Rosa', featuring a design characterised by a pink cover and a rose on the jacket, the graphic elements that would eventually label the genre itself. As Silvana Ghiazza (1991) maintains, in this phase the focus was not on the writers but almost exclusively on the imprint as a warrant of the quality of the stories ('il marchio di collana è garanzia del prodotto" ${ }^{\text {, }}$ ), a trend that, as we shall see, would change direction in the late 1930s. The popularity of such novels attracted the

\footnotetext{
${ }^{14}$ My brief review of the traditional rosa is largely indebted with the following works: Arslan and Pozzato, 'Il rosa', pp. 1027-46; Centro di documentazione ricerca e iniziativa delle donne, ed., Intorno al rosa (Verona: Essedue, 1987); Gioacchino Forte, I persuasori rosa (Naples: ESI, 1966); Silvana Ghiazza, 'Così donna mi piaci. La letteratura rosa negli anni venti-quaranta', in I best seller del ventennio: Il regime e il libro di massa, ed. by Gigliola De Donato and Vanna Gazzola Stacchini (Rome: Editori Riuniti, 1991), pp. 129-277; Lepschy, 'The popular novel, 1850-1920'; Robin Pickering-Iazzi, Politics of the Visible: Writing Women, Culture, and Fascism (Minneapolis: University of Minnesota Press, 1997); Pickering-Iazzi, 'Novel: Romance', in The Feminist Encyclopedia of Italian Literature, ed. by Rinaldina Russell (Westport: Greenwood Press, 1997), pp. 233-35; Maria Pia Pozzato, Il romanzo rosa (Rome: Edizioni L’Espresso, 1982); Michele Rak, Rosa: La letteratura del divertimento amoroso (Rome: Donizelli, 1999); Roccella, La letteratura rosa; Vittorio Spinazzola, L'immaginazione divertente: Il giallo, il rosa, il porno, il fumetto (Milan: Rizzoli RCS, 1995); Spinazzola, 'Qualche ipotesi sulla narrativa "rosa". Conversazione con Brunella Gasperini', in Pubblico 1977, ed. by Vittorio Spinazzola (Milan: Il Saggiatore, 1977), pp. 126-43.

${ }^{15}$ Under the pseudonym Delly, brother and sister Frédéric (1876-1949) and Marie (1875-1947) Petitjean de la Rosière wrote more than 100 books. Their production can be considered the epitome of the conservative ideology and educational purposes of the genre. See Ghiazza, 'Così donna mi piaci', pp. $153-55$.

${ }^{16}$ Ghiazza, 'Così donna mi piaci', p. 136-37.
} 
attention of other publishing houses that began releasing their own series: Sonzogno's 'Biblioteca Romantica Economica' and Cappelli's 'Biblioteca della Signorina' are the most notable and the most successful among readers, and many of them have maintained their leading position in the genre to the present day.

As sales figures kept growing, in the 1930s the rosa started to evolve. These years coincide with the consolidation of Fascism in Italy, when popular fiction and mass entertainment were supported by the regime as part of an articulated strategy aimed at promoting fascist ideals through reading habits. ${ }^{17}$ It is during these years that popular entertainment (fiction, radio, cinema, comics) took centre stage, with a production centred around themes such as love, passion and murder, and directed toward an audience of lower-middle class readers that was slowly but progressively expanding its demand for reading materials. From this perspective, the increase in rosa production and consumption can be seen as the combination of two factors: on the one hand, the presence of a growing number of women writers (continuing a trend started in the late nineteenth century); on the other hand, a publishing industry that wanted - and needed - to boost its reading market. In this respect, the female audience was a fundamental target, both for its size and its perceived 'natural' proximity to sentimental themes. While critics have mostly focused on the conservative aspects of the romanzi rosa

${ }^{17}$ There is no room here for a digression on Fascism and its cultural politics, which would require a more detailed historical analysis of the Italian social and political landscape. Some of the aspects related to the publishing market and reading habits can be found in the following works: Maria Luisa Betri, Leggere, obbedire, combattere: Le biblioteche popolari durante il fascismo (Milan: Franco Angeli, 1991); Carlo Bordoni, Cultura e propaganda dell'Italia fascista (Messina-Florence: D'Anna, 1974); Philip V. Cannistraro, La fabbrica del consenso: Fascismo e mass-media (Rome-Bari: Laterza, 1975); Giovanni Lazzari, Libri e popolo: Politica della biblioteca pubblica in Italia dell'Unità ad oggi (Naples: Liguori, 1985); Elisabetta Mondello, La nuova italiana: La donna nella stampa e nella cultura del ventennio (Rome: Editori Riuniti, 1987); Pier Giorgio Zunino, L'ideologia del fascismo. Miti, credenze e valori nella stabilizzazione del regime (Bologna: Il Mulino, 1985). See also my own 'Sulle ali littorie: La biblioteca A. Ponti di Imola (1922-1940)' (unpublished tesi di laurea, Bologna: Università degli Studi di Bologna, 1998), and 'Leggere al femminile: La biblioteca “A. Ponti” di Imola tra 1935 e 1940', Il Carrobbio: Rivista di studi bolognesi, 25 (1999), 267-76. 
produced during/within Fascism, such as their homogeneous and repetitive formulas and their uncomplicated representation of female fantasies, Robin Pickering-Iazzi holds a different and more challenging view. In Politics of the Visible: Writing Women, Culture, and Fascism (1997) she analyses Italian romance fiction and its conventions during the interwar years, exploring the implicit and explicit politics present in these texts. Using a critical model elaborated by Teresa de Lauretis and Cora Kaplan, Pickering-Iazzi convincingly argues that ' $[\mathrm{w}]$ ithin the hegemonic system predominated by Fascist institutions and the Catholic Church, which promoted models of femininity dedicated to the role of wife and mother, cast respectively as political and sacred, the romance novel, and mass culture in general, represented an alternative authority on modern canons of beauty and fashion, etiquette, and love'. ${ }^{18}$ Pickering-Iazzi's analysis focuses on the 1930s, but it suggests that the genre soon became the place where controversial issues such as work, independence, consumerism, sexuality and education could be acknowledged and explored by Italian women. Indeed, as I shall discuss shortly, these contradictory forces at work in rosa novels speak for the genre's enduring success and relevance in Italy's cultural and social practices until the 1980s.

In this context, critics Antonia Arslan and Maria Pia Pozzato focus in particular on the 'confronto polemico fra l'uomo e la donna', ${ }^{19}$ the confrontation between man and woman where the latter challenges and resists the former, and where the conventional happy ending is symbolised by a marriage that reconciles and harmonises the clash between the sexes. The emphasis on emotions is indeed the distinctive trait of rosa

\footnotetext{
${ }^{18}$ Pickering-Iazzi, Politics of the Visible, p. 103. See also Teresa de Lauretis, Alice Doesn't: Feminism, Semiotics, Cinema (Bloomington: Indiana University Press, 1984); Cora Kaplan, 'The Thorn Birds: Fiction, Fantasy, Femininity', in Formations of Fantasy, ed. by Victor Burgin, James Donald and Cora Kaplan (London and New York: Methuen, 1986), pp. 142-66.

${ }^{19}$ Arslan and Pozzato, 'Il rosa', p. 1028.
} 
novels, where feelings are deeply scrutinised and described. A consequence of this emphasis on the emotional relationship between man and woman is the increasingly important presence of eroticism as a defining characteristic of the rosa. Arslan and Pozzato maintain that 'l'erotismo rimane la molla essenziale e uno dei valori positivi più costanti del rosa', ${ }^{20}$ and they back up this concept by pointing out that most of the times female eroticism is legitimised by romance and marriage, but it is also a significant trait of the heroine's characterisation. In contrast with Invernizio's romanzo popolare or the novels published under the 'Romanzi della Rosa' imprint, where sensuality and female eroticism were omitted or linked to sin and perdition, rosa writers frequently allow their heroines to voice physical pleasure. As Arslan and Pozzato argue, one of the most significant traits of rosa narratives is indeed their active role in inviting both the expression of and a discussion about sentimental and sexual issues: 'il rosa non si limita a raccontare l'amore e il sesso così come sono valorizzati e vissuti nella nostra società ma è anche un invito all'amore e al sesso'. ${ }^{21}$

From this perspective, Liala (Amalia Liana Cambiasi Negretti Odescalchi, 18971995), is the "quintessenza del genre riassunto in una persona" 22 and the most popular Italian romance writer to date, with all her novels continually reprinted through the decades. Her career stretched from the early 1930s to the 1980s, and her life and writing are so deeply interwoven that they have become the rosa's prototype and foundation stone. ${ }^{23}$ A member of the Italian aristocracy, Liala married Marquis Cambiasi, who was almost twenty years older. Shortly after the marriage, however,

\footnotetext{
20 Arslan and Pozzato, 'Il rosa', p. 1029.

21 Arslan and Pozzato, 'Il rosa', p. 1036.

${ }^{22}$ Arslan and Pozzato, 'Il rosa', p. 1039.

${ }^{23}$ Roccella, La letteratura rosa, p. 53.
} 
she met the aircraft pilot Centurione Scotto and fell in love with him. Cambiasi agreed to divorce abroad (as divorce was illegal in Italy) but in 1926, before the paperwork could be completed, Scotto died while performing an acrobatic flight. Liala's first novel Signorsì, published in 1931 by Mondadori, is heavily inspired by these events and became an instant bestseller. ${ }^{24}$ Pickering-Iazzi's fascinating analysis of Signorsì highlights the 'culturally specific' form of the novel and considers it a landmark text in the genesis and development of a genre that, for the first time, was 'fashioned by Italian authors and stories'. ${ }^{25}$ In particular, Pickering-Iazzi stresses the physicality of the novel, arguing that a new perception of love, marriage and women's agency emerges throughout it, with sexual desire occupying a central position against the backdrop of dominant social and cultural practices of the time. ${ }^{26}$ Analysing the reasons behind Liala's success, Roccella notes that the writer moves away from the 'mito della Madre' heavily featured in Invernizio's works and advocates the 'mito dell'Amore', where love itself acts as the supreme power against any sin for which the heroine may be accountable. Certainly Liala's heroines do experience and enjoy motherhood, but it is never held up as having a higher claim to which women must submit ultimately; as Roccella maintains, 'Il rifiuto di ogni vocazione femminile al sacrificio di sé in Liala è fermissimo'. ${ }^{27}$ Female abnegation, in Liala's world, is replaced by desire, which for the first time receives, if not approval, at least full legitimation.

\footnotetext{
${ }^{24}$ Liala, Signorsì (Milan: Mondadori, 1931; Milan: Sonzogno, 2005). For a concise yet exhaustive account of Liala's life and editorial fortune, see Lepschy, 'The popular novel, 1850-1920', pp. 183-87. In 1950 Liala wrote Ombre di fiori sul mio cammino, a fictional autobiography that included events up to Scotto's death.

${ }^{25}$ Pickering-Iazzi, Politics of the Visible, p. 99.

${ }^{26}$ Pickering-Iazzi, pp. 119-20. Pickering-Iazzi maintains that, in the context of 1930s popular romance fiction, Signorsì resists fixed notions of femininity and masculinity alike, and offers a significant commentary on changing gender roles in Italian life and culture during Fascism.

${ }^{27}$ Roccella, La letteratura rosa, p. 53.
} 
From a formal point of view, Signorsi already presents a set of traits that would become trademarks of Liala's writing and that Pozzato aptly describes as 'estetismo di massa' ${ }^{28}$ stunning heroines and stylish heroes, moral integrity, exquisite settings infused with a sense of grandeur and refined tastes expressed through close attention to visual details, particularly when describing clothes, houses, cars and other material belongings. These features rely on a sophisticated vocabulary and syntactical constructions that are rooted in the literary movement of decadentismo, whose legacy Liala absorbed and reworked in a more popular form, aimed at a broader readership. According to Pozzato, Liala

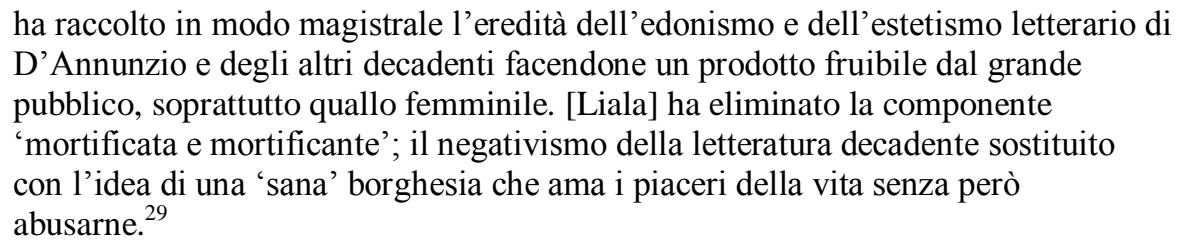

In analysing the stylistic features that subsequently came out of Liala's writing, Spinazzola talks about 'serietà assorta', that is, a certain degree of seriousness in rosa language and tone: 'l'autrice non deve permettersi mai di comicizzare le sue eroine, e prende sempre profondamente sul serio tutto quel che soffrono ${ }^{30}$ Even though light passages and interludes were always present in the course of the narrative, the overall tone needed to be solemn, because humour would eventually undermine the emphasis put on the character's evolution. I shall return to this matter later, but for now I want to point out that the privilege accorded to serietà against the perceived dangers of humour in Italian women's popular fiction is still at work in contemporary chick lit, in

\footnotetext{
${ }^{28}$ Pozzato, Il romanzo rosa, p. 90.

${ }^{29}$ Pozzato, Il romanzo rosa, pp. 89-90.

${ }^{30}$ Spinazzola, L'immaginazione divertente, p. 54.
} 
contrast with the lightweight tone of most Anglo-American production in the genre, confirming the unshakable place of rosa's practices and codes in Italy's fictional landscape.

Liala's success boosted the rosa publishing market and while she wrote well into the mid-Eighties, many other authors came along as the genre evolved. Some of them soon disappeared into the crowd of an overpopulated genre, but a few of them built close relationships with their readers from the 1930s until the late 1970s through the pages of dedicated magazines such as 'Annabella', 'Grand Hotel', 'Stop' and 'Confidenze', where they published their works in instalments but also worked as journalists and often as personal advice columnists. ${ }^{31}$ Simply by virtue of her novels' subject matter, the writer became both a motherly figure and an experienced friend, so to speak, assisting readers with complicated questions on issues related to everyday life and emotions. There is no room here to name them all, but I would like to mention at least Giana Anguissola (1906-1966), Luciana Peverelli (1902-1984) and in particular Brunella Gasperini (Bianca Robecchi, 1918-1979), whose works I shall discuss shortly.

In 1953, when popular romance was thriving among readers and publishers, Italian writer and feminist literary critic Anna Banti wrote an insightful essay on the romanzo rosa that is still relevant today for the debate around women's popular fiction in Italy. While Banti harshly dismissed these novels as 'romanzetti sentimentali, pieni di

\footnotetext{
${ }^{31}$ Both Peverelli and Gasperini, for example, were prolific journalists and contributed to the success magazines such as 'Stop' and 'Annabella' respectively; Liala, on her part, in 1946 was granted her own exclusive 'Confidenze di Liala'. See Ermanno Detti, Le carte rosa: Storia del fotoromanzo e della narrativa popolare (Florence: La Nuova Italia, 1990) and Sara Teardo, 'Alla conquista della scena: Donne e scrittura negli anni Cinquanta e Sessanta' (unpublished PhD thesis, New Brunswick: Rutgers University, 2009).
} 
lacrime inutili, ${ }^{32}$ inspired by Anglo-American models but lacking the 'elementare, brutale umorismo' (p. 79) of their foreign counterparts, she acknowledged the genre's role in reflecting women's real experiences ('specchio di una esperienza reale, vissuta', p. 80), albeit in a didactic and ideologically conservative manner. However, because of its vast diffusion among female readers, Banti was also aware of the genre's influence in Italy's cultural landscape and challenged Italian rosa writers to develop a better artistic awareness, concluding her essay with the following words:

Si può, cioè si deve anzi deve favorire, nel cosiddetto romanzo rosa, l'aspirazione a un livello più alto, a una più profonda coscienza artistica e morale. [...] Non si chiede molto: ma che il nostro romanzo di consumo si adegui, almeno, non ai modi, ma alla espressione e, insomma, al costume occidentale delle Du Maurier, delle Kennedy, delle Lehmann. Che l'imitazione, se non si vuole scavalcarla, costi almeno qualche sforzo così a chi scrive come a chi legge. ${ }^{33}$

Rather than radically condemning the writers and their works, Banti urged a transformation within the genre itself, one that would move it away from plain escapism or passive imitation and promote a deeper engagement with critically acclaimed writers such as Daphne Du Maurier (1907-1989) and Rosamond Lehmann (1901-1990), whose romance novels introduced darker themes and explored contradictory aspects of the social dynamics of their time. In doing so, Banti was asking Italian writers not to dismiss the romanzo di consumo but to render it more complex, more in tune with women's real issues and concerns, and to develop a style and language specific to the Italian rosa that would benefit the cultural and artistic sensibility of writers and readers alike.

Banti's invitation to refer to unconventional women's popular fiction and aim at a

\footnotetext{
${ }^{32}$ Anna Banti, 'Storia e ragioni del romanzo rosa', in Opinioni (Milan: il Saggiatore, 1961), pp. 75-82 (p. 76).

${ }^{33}$ Banti, 'Storia e ragioni del romanzo rosa', p. 82.
} 
conscious, skilful imitation of its style remained mostly unheard; indeed, in an essay on rosa's narrative strategies, Marina Mizzau suggests that facilità is the genre's keyword: 'il rosa dipinge un mondo in cui tutto è facile $[. .$.$] tutto è precostituito, già$ dato, stradetto, la lettrice non deve fare alcuna fatica, non deve compiere inferenze, ristrutturare le proprie aspettative'. ${ }^{34}$ However, a significant exception can be found in Brunella Gasperini, whose works initiated a different, more modern approach to Italian rosa and are often described as 'rosa d'autore' or 'rosa di qualità'. ${ }^{35}$ Throughout the 1960s and early 1970s, Italy experienced the so-called boom economico, a period characterised by a rapid economic growth and extraordinary social transformations. ${ }^{36}$ These years of great development also saw deep changes in lifestyles and customs, especially for women, which are genuinely reflected in Gasperini's novels. Arslan addresses Gasperini's work as a remarkable insight into Italian women's writing, 'uno spaccato di raro interesse della società contemporanea, e dell'evoluzione, in rapporto e in confronto dialettico con essa, della donna come soggetto e oggetto di scrittura' ${ }^{37}$ Her fictional universe typically features adolescents in conflict with the family, but the generational clash is depicted, according to Arslan, as a sentimental rite of passage for both the young and the adults. Most importantly, in Gasperini's novels humour plays an important role for the first time in the narrative context of rosa's 'serietà assorta', either through the presence of quirky characters or, more often, thanks to a fresh

\footnotetext{
${ }^{34}$ Marina Mizzau, 'Strategie narrative: Il non detto e il troppo detto', in Intorno al rosa, ed. by Centro di documentazione ricerca e iniziativa delle donne (Verona: Essedue, 1987), pp. 47-57 (p. 57).

${ }^{35}$ Arslan and Pozzato, 'Il rosa', pp. 1044-45; Roccella, La letteratura rosa, p. 96. See also Marina Tommaso, Brunella Gasperini: La rivoluzione sottovoce (Reggio Emilia: Diabasis, 1999) for a detailed account of Gasperini's production.

${ }^{36}$ See for example Adam Arviddson, Marketing Modernity: Italian Advertising from Fascism to Postmodernity (London: Routledge, 2003); Guido Crainz, Storia del miracolo italiano: Culture, identità, trasformazioni fra anni Cinquanta e Sessanta (Rome: Donizelli, 2003).

${ }^{37}$ Antonia Arslan, Dame, galline e regine: La scrittura femminile italiana fra '800 e '900 (Milan: Guerini studio, 1998), p. 77.
} 
writing that mimics the spoken language of the time. In this way, the genuine and ironic light in which the characters' sense of displacement is narrated results in a progressive and original 'bildungsroman femminile e adolescenziale'. ${ }^{38}$

During the 1980s, however, a wholly different scenario emerged: in 1981 the leading worldwide publisher of serial romance, Harlequin Enterprises, joined forces with Arnoldo Mondadori Editore, the historical Italian publishing house that had been one of the first to actively engage with the mass-market fiction since the late $1920 \mathrm{~s},{ }^{39}$ and launched Harmony, a joint-venture designed to publish exclusively serial romances in translation. The Canadian-based publisher had changed the way popular romance was approached and understood, combining commercial awareness and editorial strategies where everything, from the writing guidelines to the artwork, was accurately defined by production rules. ${ }^{40}$ Following suit, Harmony became almost immediately the reference point for a new kind of romance fiction in Italy, one that decreed the end of the so-called 'rosa artigianale', that is, locally crafted, in favour of a

\footnotetext{
${ }^{38}$ Roccella, La letteratura rosa, p. 98.

${ }^{39}$ For example, in 1929 'I libri gialli' (later renamed 'I Gialli Mondadori') was the first mystery/crime fiction series to hit Italy's market; 'Urania', the first science fiction imprint, was launched in 1952. Still active and successful imprints in their respective fields, while at the beginning they featured mostly translations of American novels, they are now including many local authors as well. See Ragone, 'Editoria, letteratura e comunicazione'; Bordoni, Il romanzo di consumo; Benedetta Bini, 'Il poliziesco', in Letteratura Italiana, Storia e geografia, III, ed. by Alberto Asor Rosa (Turin: Einaudi, 1989), pp. 999-1026. It is also worth noting that in the 1930s Mondadori began to publish Topolino, a children's periodical that featured Disney's comic Mickey Mouse and that signed an exclusive and long-lasting collaboration with the American colossus. See 'Disney Legends - Arnoldo Mondadori' $<\mathrm{http}: / /$ legends.disney.go.com/legends/ detail?key=Arnoldo+Mondadori > [accessed 28 February 2011]. ${ }^{40}$ Founded in 1949 as paperback publisher, in 1957 the Toronto-based Harlequin company started importing titles from Mills \& Boon, the famous British publisher of romance fiction since 1909; due to the increasing success of the genre, by 1964 Harlequin was publishing romance fiction exclusively. Today it releases more than 115 titles a month in 25 different languages, distributed in 94 international markets. See Harlequin Enterprises Limited 'A Global Success Story' < http://www.eharlequin.com/ store.html? cid=2659> [accessed 1 March 2011]. For the history of Harlequin Enterprise and its impact on society, romance and readers, which because of space constraints I cannot fully discuss here, see Margaret Ann Jensen, Love's \$weet Return: The Harlequin Story (Toronto: The Women's Press, 1984).
} 
new and imported 'rosa seriale'. ${ }^{41}$ The latter flooded the marketplace with an abundance of titles ranging from historical to Regency to contemporary romance, offering entertaining stories as diverse as individual tastes. Within a couple of years, the success of Harmony novels among Italian readers was staggering: easily available in newsstands and supermarkets, and later via direct subscriptions, in 1983 readers were offered 25 new titles each month, all translated from English and quickly recognisable through definite visual features. ${ }^{42}$ In fact, it could be said that Harmony brought romance back to the early 1920s, when the imprint, rather than the author or the individual book, was the element that guaranteed the reader's fidelity to the genre. Moreover, with regard to narrative features, Roccella has noted that the success of 'rosa seriale' in Italy came mainly from the explicit and almost exclusive thematic shift toward exotic scenarios, female desire and sexuality, in contrast with the realistic features and pedagogical aims at the core of 'rosa artigianale', which Italian women were now perceiving as obsolete. ${ }^{43}$

Forced to compete against aggressive marketing strategies and new forms of consumption, from the 1980s onward the home-grown rosa production and its literary tradition, which was already struggling to reposition itself in Italy's rapidly-changing society of the 1980s, slowly disappeared under the weight of what Arslan and Pozzato have called 'l'acritica colonizzazione da parte di modelli stranieri' ${ }^{44}$ While issues of

${ }^{41}$ Roccella, La letteratura rosa, pp. 109-14.

42 Alberto Brodesco, 'Harmony: L'amore in edicola', in Luigi Del Grosso Destrieri, and others, Una galassia rosa: Ricerche sulla letteratura femminile di consumo (Milan: Franco Angeli, 2009), pp. 37-83 (pp. 42-45). According to Harmony's website, the latest sales figures account for 5 million copies sold each year (400 millions in thirty years), with around 50 titles released monthly:

<http://www.eharmony.it/ Chi-siamo/Harmony-Italia> [accessed 1 March 2011].

${ }^{43}$ Roccella, La letteratura rosa, p. 116. See also Rak, Rosa: La letteratura del divertimento amoroso, pp. 68-72.

${ }^{44}$ Arslan and Pozzato, Il rosa, p. 1046. 
globalisation remain a widely debated subject, one that involves the examination of power relations, socio-economic factors and many other elements the analysis of which would go beyond the scope of this thesis, their presence in critical discussions brings to the forefront the relationship between forms of global entertainment and local cultures, which in the following pages I shall discuss with regards to chick lit.

\subsection{Chick lit between globalization and local adaptations}

Studies on the globalization of media and cultural industries outline a process that entails a wider distribution of cultural products and, at the same time, a wider circulation of the discourses about such products, particularly in relation to local practices. Some scholars have looked at the macro-level and focused on concepts such as 'cultural' or 'media imperialism' in order to highlight a one-way process in which Western cultural industries have dominated (if not erased) local and national cultures, ${ }^{45}$ while others have developed different approaches that investigate the heterogeneous aspects of global culture, and it is to the latter that I look at in my analysis of Italian chick lit. Joseph Straubhaar, for example, has focused on the role of the audience and has elaborated the concept of 'cultural proximity' to refer to a complex and relatively recent phenomenon in which the heavy consumption of imported cultural products has been accompanied by the production of equally successful indigenous ones, thus showing how local audiences seem to demand 'cultural proximity in cultural goods'; 4 in other words, cultural proximity highlights how cultural products that appeal to an

\footnotetext{
${ }^{45}$ For a comprehensive overview on cultural imperialism and its ramifications, see John Tomlinson, Cultural Imperialism: A Critical Introduction (London: Pinter Publishers, 1991).

46 Joseph D. Straubhaar, 'Beyond Media Imperialism: Asymmetrical Interdependence and Cultural Proximity’, Critical Studies in Mass Communication, 8, (1991), 39-59 (p. 39).
} 
international audience may give rise to "nationally or locally produced material that is closer to and more reinforcing of traditional identities ${ }^{47}$ on the grounds of shared cultural, social, and ideological characteristics. In Modernity at Large, Arjun Appadurai talks of 'global cultural flows' operating across five dimensions, which he names 'ethnoscapes', 'mediascapes', 'technoscapes', 'finanscapes' and 'ideoscapes' and that relate to people, images, machinery, finance, images, and ideologies respectively. ${ }^{48}$ In particular, Appadurai argues that global cultural flows occur 'in and through the growing disjunctures ${ }^{49}$ in these five dimensions and move across national boundaries, leading to complex relationships of mobility and fluidity.

In the field of cultural studies, Jan Nederveen Pieterse sees globalisation as 'a process of hybridization which gives rise to a global melange', drawing attention to the coexistence of different hybridities: one that simply assimilates the canon, and one that creatively reuses it. ${ }^{50}$ In this respect, writing about women's popular culture, Tania Modleski has recently stated that in this day and age 'globalization permits the dissemination of mass-produced fantasies to and from far reaches of the planet'. ${ }^{51}$ Modleski's emphasis on the bi-directional process gives insight to the discursive possibilities that inhabit globalisation, where cultural production is neither vertically imposed nor it is univocally consumed, but it becomes a polysemic body of texts - a hybrid, I would say - that different audiences may produce and consume in different ways.

${ }^{47}$ Straubhaar, 'Beyond Media Imperialism', p. 51.

${ }^{48}$ Arjun Appadurai, Modernity at Large: Cultural Dimensions of Globalization (Minneapolis: University of Minnesota Press, 1996), p. 33.

${ }^{49}$ Appadurai, Modernity at Large, p. 37.

${ }^{50}$ Jan Nederveen Pieterse, 'Globalization as Hybridization', in Global Modernities, ed. by Mike Featherstone, Scott Lash and Roland Robertson (London: Sage, 1995), pp. 45-68 (pp. 56-57).

${ }^{51}$ Tania Modleski, Loving with a Vengeance: Mass-Produced Fantasies for Women, $2^{\text {nd }}$ edition (New York: Routledge, 2008), p. xxxii. 
A New York Times article on international chick lit published in $2006^{52}$ observed that parallel to the novel's success in English-speaking countries, translations of Bridget Jones's Diary ${ }^{53}$ immediately appeared worldwide: in Italy, France and Japan in 1998, then in Hungary, Korea and Indonesia, to name but a few. Indeed, the novel's clever gesturing at both 'triviality and seriousness' pointed out by Clare Squires made its appeal across the global market possible, building the base for subsequent variations. ${ }^{54}$ Local publishers promoted and launched domestic writers alongside the translations of American and British ones, and while this could be seen as nothing more than a product placement technique, trying to capitalise on a worldwide commercial success, one should not overlook the fact that chick lit is a social and cultural phenomenon that has promoted a great deal of creative response. If it is true that translated novels have often been acritically imitated by local writers, they have also built the base for original creative efforts, launching a new genre for women writers and readers. In fact, regardless of the common traits they may share with the archetypal texts, many of these novels and writers infuse chick lit with local elements that, in their respective social, cultural and historical context, rely on 'cultural proximity' to produce hybrid texts that use the canon in order to make meaning.

Thus, on the one hand the chick lit genre is a successful commercial franchise that plays into both the fantasies and the anxieties of contemporary women in industrialised Western countries; on the other hand, as a growing body of studies notes, the genre's framework has been hijacked and transformed in accordance with local socio-cultural

\footnotetext{
52 Rachel Donadio, 'The Chick Lit Pandemic', The New York Times, 19 March 2006, p. 31 <http://www.nytimes.com/2006/03/19/books/review/19donadio.html> [accessed 05 January 2008]. ${ }^{53}$ Helen Fielding, Bridget Jones's Diary (London: Picador, 1996).

${ }^{54}$ Claire Squires, Marketing Literature: The Making of Contemporary Writing in Britain (New York: Palgrave Macmillan, 2007), p. 160.
} 
needs and values across the globe. In Austria, for example, feminist playwright and writer Marlene Streeruwitz's novel Jessica, 30 (2004) has been read in light of the style and themes of Bridget Jones's Diary, which the author exploits to comment on social and political events in her country. ${ }^{55}$ In 2002, freelance journalist Zsuzsa Rácz published a novel that was hailed as the 'Hungarian Bridget Jones', prompting Nora Sellei to investigate the reception of both Fielding's character and her local counterpart in postcommunist Hungary. ${ }^{56}$ In calling for a new interpretative framework for Rácz’s novel, Sellei maintains that while it openly acknowledged its debt to Bridget Jones's Diary, it was also unmistakably 'rooted in a complex but subtle way in Hungary's postcommunist present', capturing in real time the changes in language, society and culture of the country. ${ }^{57}$ Similarly, Jenny Mochtar Djundjung's work on chick lit in Indonesia offers a comparative reading of British and Indonesian texts that focuses on the representation and reception of key elements such as the female body and the 'urban single career woman'. Djundjung argues that despite the borrowing of stylistic features, paratextual elements and narrative tropes, Indonesian writers do not endorse nor engage with the postfeminist debate that characterises the genre in Western countries, conforming instead to local patriarchal ideologies that hold marriage and

\footnotetext{
${ }^{55}$ See Allyson Fiddler, 'Of Political Intentions and Trivial Conventions: Erika Pluhar's Die Wahl (2003) and Marlene Streeuwitz's Jessica, 30. (2004)', German Life and Letters, 64 (2011), 133-44 (pp. 13839); Brenda Bethman, “'Chick-Lit” Revisited: Bridget Jones Meets Jessica, 30', 2005 <http://www.womeningerman.org/conference/2005/epanel/bethmanwig2005synopsis.pdf> [accessed 19 May 2008].

${ }^{56}$ Nora Sellei, 'Bridget Jones and Hungarian Chick Lit', in Chick Lit: The New Woman's Fiction, ed. by Suzanne Ferriss and Mallory Young (New York: Routledge, 2006), pp. 173-88 (pp. 173-74). A similar analysis has been carried out by Ksenija Vidmar-Horvat with regard to the TV show Ally McBeal, another iconic media product within popular postfeminism, in 'The Globalization of Gender: Ally McBeal in Post-socialist Slovenia', European Journal of Cultural Studies, 8 (2005), 239-55.

${ }^{57}$ Sellei, 'Bridget Jones and Hungarian Chick Lit', pp. 179-85.
} 
children as the expected path for women. ${ }^{58}$ Likewise, the rise in China of a new generation of young women writers engaging with themes such as consumerism, eroticism and the urban lifestyle has been dubbed 'Chinese chick lit' and read in the context of the recent changes in the socialist market economy of the country, where discourses of globalised consumer culture, female empowerment and neoliberal agency borrowed from Western postfeminist media culture are shaping - but are also being shaped by - urban Chinese women at ease with commodities and languages from the West. In discussing Shanghai Baby, the controversial 1999 novel banned in China that became an international best seller, Eva Yin-I Chen stresses its forceful and thought-provoking relationship with Western postfeminism and consumer culture. Wenche Ommundsen speaks of 'crossover fiction' in her analysis of Chinese chick lit written in English that reflects and comments, often in darker tones, on 'the lives and aspirations of the young Chinese women who inhabit the new world of global cosmopolitanism'. ${ }^{59}$ Finally, Pamela Butler and Jigna Desai approach the question of globalisation by looking at South Asian American chick lit through the lens of transnational and race feminist critique. Their analysis of the middle-class American multiculturalism presented in chick lit brings to light the literary strategies 'that identify and play on contradictions in the production of neoliberal feminine

\footnotetext{
${ }^{58}$ Jenny M Djundjung, 'The Construction of Urban Single Career Woman in Indonesian Chick Lit, Jodoh Monica', K@ta, 6, (2004), 106-23; 'Beautiful Body and Femininity in Five British and Indonesian Chick Lit' (Surabaya: Petra Christian University, 2007) <http://fportfolio.petra.ac.id/ user_files/86-12/Beautiful\%20Body\%20 and\%20Feminity.doc> [accessed 19 May 2008].

${ }^{59}$ Eva Yin-I Chen, 'Shanghai Baby as a Chinese Chick-Lit: Female Empowerment and Neoliberal Consumerist Agency', Asian Journal of Women's Studies, 15 (2009), 54-93; Wenche Ommundsen, 'From China With Love: Chick Lit and The New Crossover Fiction', in China Fictions/English Language: Literary Essays in Diaspora, Memory, Story, ed. by A. Robert Lee (Amsterdam: Rodopi, 2008), pp. 327-45 (p. 334). For the reception and production of chick lit in Asia, see also 'This One's For the Girls: Asians Embrace Chick Lit', Newsweek Magazine, 11 June 2009 <http://www.thedailybeast.com/newsweek/2009/06/11/this-one-s-for-the-girls.html> [accessed 12 October 2009].
} 
subjectivity, and thus reimagine the contradictory possibilities for subjectivity in the context of neoliberal capitalism and globalization' ${ }^{60}$ In doing so, they suggest that themes such as immigration and race add layers to the genre's fabric that can potentially trigger disruptive effects on its neoliberal feminist narrative.

What all these interpretations (and appropriations) of the chick lit 'brand', so to speak, clearly indicate is a lively tension between the local and the global that operates on multiple and often contradictory levels. This confirms the central position of the genre in the marketplace, and invites further investigation about the need of 'cultural proximity in cultural goods'. This bring me back to Italy, where in 2002 the Italian publishing house Mondadori teamed up with Harlequin Enterprises for the second time to import the chick lit's Red Dress Ink imprint; shortly afterwards, other national publishers - particularly the ones with a solid background in popular romance fiction started to launch dedicated chick lit series, such as Morellini’s Pink Generation, Sperling \& Kupfer's Pandora Shocking, Piemme’s Femminili and Newton Compton’s Anagramma. While initially such series focused mainly on translations, introducing the Italian readership to the most successful American and British chick lit writers, Italian authors became gradually more and more visible. The pivotal year for Italian chick lit was however 2005, when publisher Newton Compton published Federica Bosco's first novel Mi piaci da morire under Anagramma, the imprint dedicated until

\footnotetext{
${ }^{60}$ Pamela Butler and Jigna Desai, 'Manolos, Marriage, and Mantras: Chick Lit Criticism and Transnational Feminism', Meridians: Feminism, Race, Transnationalism, 8 (2008), 1-31 (p. 9 and p. 28). In the context of race and transnational perspectives, an interesting essay on the translation of Rajaa Alsanea's Banat al-Riyadh for the Anglophone market reveals that chick lit's narrative style and paratextual features have been used to bypass its political and social commentary on Muslim women in Saudi Arabia, framing it into the more familiar (and unproblematic) "broader context of popular feminine memoir "from behind the veil"'. See Marilyn Booth, "The Muslim Woman" as Celebrity Author and the Politics of Translating Arabic: Girls of Riyadh Go On The Road', Journal of Middle East Women's Studies, 6 (2010), 149-82 (p. 174) , <http://muse.jhu.edu/journals/journal_of_middle_ east_womens_studies/v006/6.3.booth.html> [accessed 12 January 2011].
} 
then to Anglophone chick lit. Translated into Spanish, German and Portuguese, Bosco's book spawned two sequels and celebrated the writer as 'l'autrice italiana più amata dalle italiane'. ${ }^{61}$ I shall examine Anagramma and Bosco's fiction extensively in Chapter 3; for now, I would like to stress that its success encouraged Newton Compton to look out for more Italian writers to launch, aiming to secure a niche in a new and thriving market and soon becoming the leading imprint of Italian chick lit. Following Newton Compton's example, many other publishers have perused the market in search of indigenous writers, and from 2006 more and more chick lit texts have been published. The success of these writers, as well as the vast popularity of the genre, are confirmed not only by sales figures but also by the constant evolution of the genre. This is clearly evidenced, for example, by the case of ChickCult, a brand new editorial project launched in 2009 by Arpanet, which aims at presenting chick lit novels that celebrate Italian culture and contemporary trends and lifestyles: 'ChickCult è la collana ARPANet dedicata alla narrativa chicklit quando diventa Cult, ovvero culturale! [...] tutto quanto abbia a che vedere con le radici della nostra cultura o le nuove tendenze contemporanee sono i set in cui si snodano le storie proposte in questa nuova collana, tutta al femminile, per letture divertenti e appassionanti, caratterizzate da uno stile leggero, piacevole, ironico e scanzonato'. ${ }^{62}$ Aspiring writers are invited to submit witty and light-hearted stories in which the protagonist is a young woman working in a specifically Italian sociocultural context, such as universities, museums, art galleries, theatres and so on.

\footnotetext{
${ }^{61}$ Newton Compton Editori website, <http://www.newtoncompton.com/index.php?lnk=600> [accessed 10 March 2010].

62 Arpanet's press release is available on the ChickCult website, <http://www.chickcult.it/ ilgenerechickcult.asp> [accessed 10 March 2010]. So far three titles have been published.
} 


\subsection{The making of Italian chick lit: Un anno di Gloria (2001), Valentina compra tutto (2002) and Qualcosa bolle in città (2004)}

In the next pages I will map out the genre's arrival in Italy by talking in detail about three Italian novels published in the early 2000s that were the first to openly claim a direct connection with some of the most successfull Anglo-American models:

Casella's Un anno di Gloria, Magnanini's Valentina compra tutto, Vittorini’s Qualcosa bolle in città. I will focus on specific key aspects of the chick lit genre such as the single woman, the first-person narrator and the humorous tone, as well as the attention accorded to consumer culture and an urban lifestyle, investigating how they are reproduced and interpreted in the Italian narratives.

\subsubsection{Un anno di Gloria}

In 2001 Salani released Un anno di Gloria (UAG from now on), a book that reworked in the form of a diary a series of columns written for the Italian edition of women's monthly 'Cosmopolitan' by Alessandra Casella (b. 1963), a well-known TV presenter and journalist. Given the fact that Bridget Jones's Diary (BJD from now on) had also developed out of her weekly columns on the British newspaper The Independent, this element fostered a marketing connection between the British prototype of chick lit and the 'Italian cousin of Bridget Jones', as Gloria was defined not only by the publisher but also by the author herself, who claimed however some authenticity: 'Non ho approfittato di un filone, ma lo ho cavalcato anche perché solo allora mi hanno pubblicato. [...] D'altronde ci sono punti in comune tra le single di tutto il mondo. ${ }^{63}$

63 'Essere donna, leggere, scrivere... Ce ne parla Alessandra Casella', Infinitestorie, 
The novel is the fictional diary of the life of Gloria, an Italian woman working as secretary in an advertising agency. Much like her British 'cousin' Bridget, thirtysomething Gloria is stuck in a dead-end job, overweight, and unhappy with her sentimental life. Tired of her lack of direction, on New Year's Day she finally decides to be proactive and change her attitude. Indeed, the blurb on the front cover reads 'Il diario spumeggiante di una single nostrana in cerca di amore e avventura', suggesting humour ('spumeggiante') and love as the novel's main themes, with a pinch of localism ('single nostrana') and transgression ('in cerca di amore e avventura'): the formula of Italian chick lit was apparently born. As we shall see, however, $U A G$ does not live up to its claims. On the one hand, it falls short in capturing the spirit of the British counterpart, which is especially evident in the unsuccessful adoption of the main literary device, the real-time diary; on the other hand, the attempt at addressing Italian culture and lifestyle proves to be equally ineffective.

Before looking closely into the novel's literary and stylistic features and bearing in mind the role of the paratext in building Anglophone chick lit's identity, I want to examine how, if at all, this has been used in Casella's book to sustain its placement within the genre. As I discussed at length in Chapter 1, Gérard Genette famously noted that the paratextual elements of a book are a 'threshold' that the reader can cross or turn. ${ }^{64}$ Indeed, covers generate a great deal of meaning, giving an idea of the genre, tone and the kind of audience the book seeks. As a strategic marketing element, covers are therefore chosen carefully, and since I consider Casella's novel as one of the first attempts to present Italian chick lit to the local market (where chick lit in 1997), p. 1. 
translation was already thriving ${ }^{65}$ ), a look at its cover proves to be particularly interesting.

Although the protagonist Gloria has been described as Bridget's Italian cousin, forcefully invoking a link between the main characters of the two books, their respective covers couldn't be more different. Fielding's cover showed the blurred profile of a young woman holding a cigarette in one hand and a glass of wine in the other, suggesting some kind of sophistication and independence (Figure 1). It may seem patently obvious, but is worth noting that, at the time, such a cover had no resemblance at all to what we now consider a typical chick lit design. Indeed, it can almost be said that it reflected the ambiguous position of the novel across genres, or as Squires has pointed out, its lack of a clear 'definability' in the publishing market. ${ }^{66} \mathrm{I}$ suggest that, for the same reason, the cover of the Italian translation remained very faithful to the original, showing the picture of a young woman holding a cigarette, against a bright red background (Figure 2) ${ }^{67}$ Five years later, with $B J D$ a worldwide phenomenon and chick lit in full bloom, Casella's Italian counterpart featured the silhouette of a woman in heels, carrying shopping bags (Figure 3). The thin female body wearing a 'little black dress' is presented from the waist down with a focus on the shoes, in line with canonical chick lit iconography; however, the glam suggested by the dress and shoes is counteracted by the setting, that is, a brown cracked wall, a

\footnotetext{
${ }^{65}$ See Maria Novella De Luca, 'Passioni e intrighi senza lieto fine: così cambia il romanzo per single', La Repubblica, 21 February 2002, p. 30; Livia Manera, 'Arrivano le single, regine della narrativa', Il Corriere della Sera, 13 July 2000, p. 35; Giuliano Vigini, 'Single', Il Corriere della Sera, 17 March 2002, p. 28.

${ }^{66}$ Squires, Marketing Literature, p. 154.

${ }^{67}$ It should be noted that subsequent movie tie-ins had different covers, each in its way a significant chapter in the paratextual history of the book, the analysis of which would call for a much lengthier discussion that goes beyond the scope of my dissertation.
} 


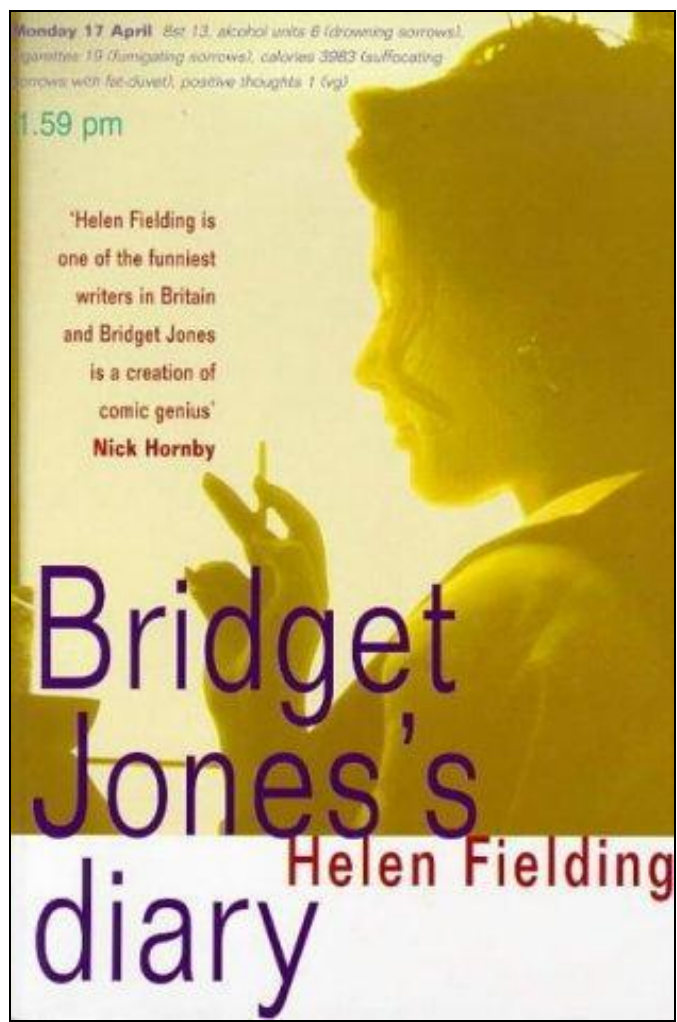

Figure 1. Cover of Helen Fielding's Bridget Jones's Diary, 1996.

(C) Picador.

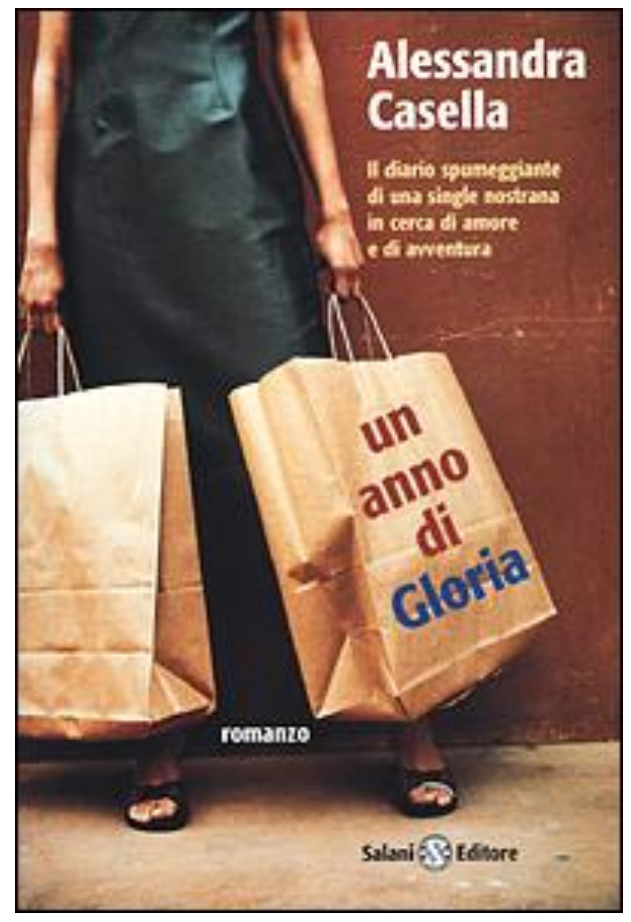

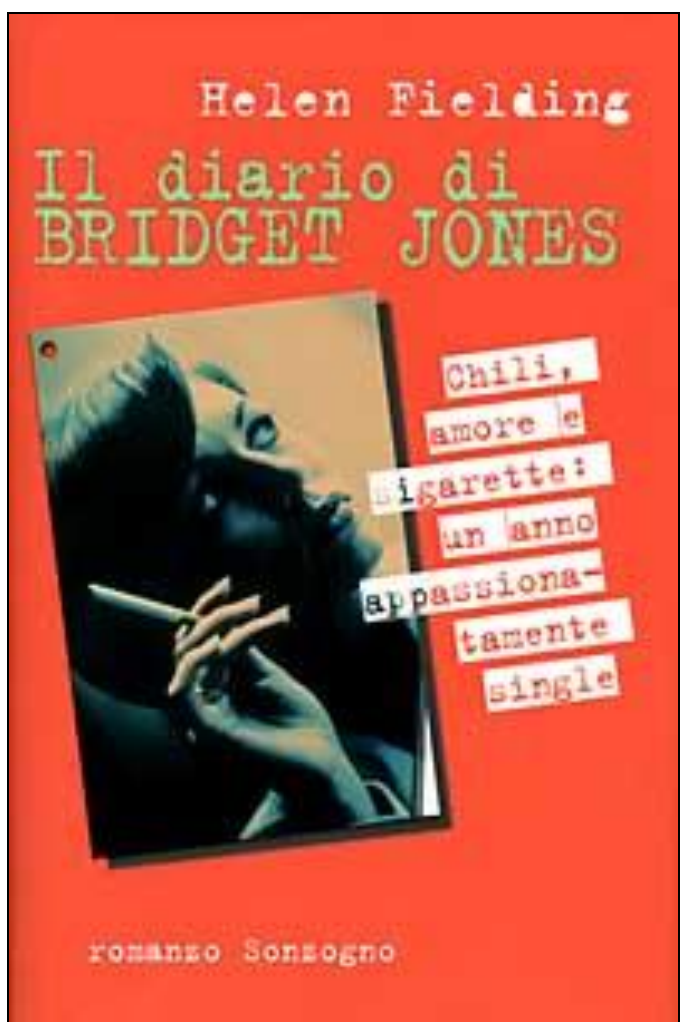

Figure 2. Cover of Il diario di Bridget Jones, 1998. (C) Sonzogno.
Figure 3. Cover of Alessandra

Casella's Un anno di Gloria, 2001.

(C) Salani. 
yellowish dirty floor, and plain paper-bags. Much like BJD's cover, I believe that the Italian one comes across as a puzzling 'threshold', one that readers may find difficult to cross; in this respect, I would argue that the incongruity between the glamorous outfit and the cheap environment mirrors the tentative shaping of a character (that is, an Italian 'Bridget Jones ${ }^{68}$ ) that, at the time, had no distinct outline. Therefore, in both cases the role of the front cover copy and the title is to make up for such indistinct meaning, albeit with different results.

$B J D$ 's copy is a quote taken directly from the novel about calories intake, alcohol units and cigarettes smoked, whereas $U A G$ 's is a one-sentence summary of the novel itself: the exciting diary of an Italian single woman looking for love and fun. Cogent in terms of marketing strategies, this copy is however unconvincing from a generic point of view: on the one hand, it points out the book's innovative nature in the context of women's popular fiction; on the other hand, however, a phrase like 'il diario di una single nostrana' is too evident a gesture towards $B J D$, one that eventually will invalidate Gloria's anticipated originality. This is not the case with the title, which successfully reinvents the British one. Referring to Genette's different functions of the title in placing books into the space of the reader, it can be said that both $B J D$ and $U A G$ are descriptive titles, as they refer to the content of the novel; ${ }^{69}$ however, Casella's has also a seductive function, one that is absent in Fielding's. Genette defines the seductive (or tempting) function as what a title should or should not suggest to the reader in relation to their interpretation of the book, and indeed $U A G$, playing on the

\footnotetext{
${ }^{68}$ In line with Squires, I use here the term 'Bridget Jones' to identify not only 'a certain social type [but also] a certain sort of novel and a certain sort of success'. See Squires, Marketing Literature, pp. 158-59. ${ }^{69}$ Genette, Paratexts, pp. 89-93; see also Genette, 'Structure and Functions of the Title in Literature', Critical Inquiry, 14 (2008), 692-720.
} 
character's name, is open to multiple suggestions: it can be literally read as 'a year in the life of Gloria', but also as 'a year of glory' or, perhaps better, 'a glorious year', inviting the reader to speculate about the character's storyline.

Paratextual observations aside, let us a look at the textual elements of Casella's novel vis-a-vis Fielding's model. Both texts share the diary form, the female first person narrator and the humoristic tone, along with a courtship plot in which the protagonist falls in love with the wrong man but eventually finds true love. Also, both protagonists struggle with the shape and size of their body and resort to dieting programs and magazine advice in order to keep it under control. They also have conflictual relationships with their respective families (especially their histrionic mothers), but can count on a tight circle of friends that compensates for this, including a trusted gay male character. These key elements, however, are managed in ways that lead to very different results. The first two, namely the use of diary entries and the first-person narrator, call for a colloquial style that, together with the confessional tone, connects the reader with the emotional life of the protagonist. Fielding opted for a style shaped around broken syntax, lively, everyday jargon, overlapping thoughts and minute-byminute recording of events. The apparent lack of stylistic and narrative control (which in reality is crafted very carefully), served the purpose of putting Bridget's anxieties to the forefront and making them not only real, but also 'authentic', encouraging readers to empathise with her plight. ${ }^{70}$ This is not the case with Casella, who maintains a far more traditional narrative approach: entries follow one another in regular descriptive patterns; on the whole, standardised colloquial language dominates the narrative and

${ }^{70}$ Imelda Whelehan, Helen Fielding's Bridget Jones's Diary: A Reader's Guide (New York: Continuum, 2002), p. 23. 
jargon is kept to the minimum, while the loose writing typical of diaries is mainly supplied through exclamation marks, suspension dots and uppercases (to emphasise strong emotions), as in the following excerpt: 'HO FAMEEE! Signore santo, dammi la forza di continuare [la dieta] - oppure mandami dal cielo un po’ di manna light, perché tra poco io scendo in pizzeria e faccio uno sfracello!'. ${ }^{71}$ As a consequence of her dieting program Gloria is constantly hungry and eventually vents her frustrations, but, as we can see, the effort put in producing a colloquial and effective style is truly minimal.

In particular, a closer look at Casella's prose shows how the humoristic tone, the most important element of the genre, is strongly undermined. Critics such as Imelda Whelehan have pointed out that Fielding's ability to render a truthful character is largely based on her clever 'observational humour', which in turn makes $B J D$ 'a book that constantly comments on itself' ${ }^{72}$ Given Casella's background as a comic actress, it is quite surprising that her style and language fall short in precisely these qualities. Despite her efforts to maintain a witty approach to Gloria's adventures, the serious tone often takes over the humoristic one; as a result, the overall atmosphere is one of sombreness, as evident when we compare the following quotes from $B J D$ and $U A G$ :

[...] I feel ashamed and repulsive. I can actually feel the fat splurging out from my body. Never mind. Sometimes you have to sink to a nadir of toxic fat envelopment in order to emerge, phoenix-like, from the chemical wasteland as a purged and beautiful Michelle Pfeiffer figure. Tomorrow new Spartan health and beauty regime will begin. (BJD, p. 18)

[guardo] le mie gambe, mollicce e cellulitiche [...] metto una cassetta di musica cubana e ballo, mentre sento la ciccia che danza in controtempo. Non importa, diventerò magrissima e bellissima, e sarò amata alla follia . Mentre ballo, sogno un uomo bruno che assomiglia ad Andy Garcia, poi a Banderas e poi a nessuno, ma mi ama. (UAG, p. 16)

${ }^{71}$ Casella, Un anno di Gloria, p. 25.

${ }^{72}$ Imelda Whelehan, The Feminist Bestseller. From Sex and the Single Girl to Sex and the City (New York: Palgrave Macmillan, 2005), pp. 185-89. 
Both passages are intended to describe comically overweight and self-image issues, emphasising the 'fat splurging out' from the protagonists' bodies. However, while Fielding's phrasing reworks Bridget's anxieties in a comical and self-mocking manner that underlines their absurdity, Casella's is infused with a sense of misery that puts off any attempt at humour.

The above passages also highlight how the two writers use popular culture references in connection with ideas of conventional feminine beauty, a significant element of chick lit. Bridget's beauty icon is American actress Michelle Pfeiffer, whose slender and sinuous figure she aims to conquer thorough a 'Spartan health and beauty regime' that would regenerate her like a phoenix. Here the reference to ancient Sparta's extreme fitness and to the mythological bird that symbolises spiritual renewal are reframed in a popular culture context that underscores both the impracticality and the hilariousness of Bridget's plan to attain the type of feminine beauty that Pfeiffer embodies in media culture. By contrast, Casella's passage strikes for the lack of any such hyperbolic references, which are replaced with Latino actors Andy Garcia and Antonio Banderas, at the time hailed as sex-symbols in women's magazines. Dancing alone in her living room, Gloria dreams of becoming 'magrissima e bellissima' so that a man like Garcia or Banderas would fall in love with her. The prominence given to the two mainstream Latino movie stars not only draws on predictable images of exotic masculinity halfway between machismo and sensibility, but it also puts Gloria in a subordinated position that considerably undermines her agency, the daydreaming and the comic effect altogether. 
When comparing the two novels, the treatment of the gay male friend play out very differently again. While in $B J D$ Tom ironically asserts that 'homosexuals and single women in their thirties have natural bonding: both being accustomed to disappoint their parents and being treated as freaks by society, ${ }^{73}$ Gloria's gay friend Dario, also called 'Il Divino' because of his success with men and exquisite tastes in fashion, banally states: 'Per fortuna voi donne non capite niente di uomini'. ${ }^{74}$ More specifically, Dario is depicted as a sexually assertive figure and his main role in the narrative is to give Gloria guidance on how to seduce a man. The following excerpt gives an idea of the tone of his advices:

[Dario] si è precipitato a casa mia per una lezione di zoccolaggine [...] "Mai lasciare che siano loro a guidare il gioco. Devono credere che li prendi e li molli a tuo piacimento, e che sei disponibile, sì, ma solo se va a te. Devi farli morire: sii arrapante, poi elusiva, poi presissima, ma subito dopo non ti fai trovare, sfuggente - in amor vince...",75

The ironic intention of this passage fails less for the nature of the advice than for the stereotypical way in which it is delivered. For example, zoccola is a dialect word charged with demeaning connotations, and the context in which writers use it makes a difference with regard to the effect they want to obtain. In this case Casella adopts a cheerful spoken variation ('una lezione di zoccolaggine'), so that readers would expect Dario to be chatting away about sex and displaying an extensive range of experiences, but the expectations deflate when Dario's talk turns out to be that of an outdated selfhelp manual filled with clichéd images of sexually active women: 'li prendi e li molli a tuo piacimento [...] sii arrapante, poi elusiva'.

\footnotetext{
${ }^{73}$ Fielding, Bridget Jones's Diary, p. 27.

${ }^{74}$ Casella, Un anno di Gloria, p. 39.

${ }^{75}$ Casella, Un anno di Gloria, p. 43.
} 
In this context, I want to draw attention to another prominent feature of the genre, that is, the reference to advice manuals marketed to women, which both Bridget and Gloria read eagerly throughout the novel. Indeed, the characters are portrayed as women who read self-help manuals and magazines only and are unaccustomed to literary fiction. Caroline Smith's work on chick lit and consumer culture media explores how chick lit protagonists interact with them, showing that they constantly turn to women's advice manuals, magazines and self-help books as their guide to cope with the 'expected feminine behaviors and ideals that they should attempt to achieve'. ${ }^{76}$ Smith notes that because the language and style of advice manuals and selfhelp books boasts 'prescriptive instructions [...] that guarantee results', by having the characters blindly following their directives chick lit cleverly questions their effectiveness and often reveals their limited, when not inadequate, value. ${ }^{77}$ This is evident in Bridget's mixed feelings towards magazines like Cosmopolitan and the notorious Men Are from Mars, Women Are from Venus (1992), while Gloria compulsively buys self-help and dating manuals only to realise that they never provide effective instructional guide.

Where Fielding and Casella's narrative strategy diverts, however, is that in $U A G$ self-help manuals are soon replaced by literary novels, to which Gloria is introduced by a male colleague who will eventually become her true love. Much to her surprise, these books turn out to be a life-changing experience, and literary reading becomes for Gloria a form of self-help therapy. Elizabeth Long and, more recently, Jim Collins have investigated the relationship between reading practices and self-cultivation.

\footnotetext{
${ }^{76}$ Caroline J. Smith, Cosmopolitan Culture and Consumerism in Chick Lit (New York: Routledge, 2008), p. 5.

${ }^{77}$ Smith, Cosmopolitan Culture and Consumerism in Chick Lit, pp. 11-12.
} 
Long's Book Clubs: Women and the Uses of Reading in Everyday Life maintains that '[books and reading groups] are examples of one of the defining ways we make ourselves today', ${ }^{78}$ and examines how middle-class, white female readers connect to canonical books and discuss them, negotiating literary authority with their own background and culture. ${ }^{79}$ Long's emphasis on the development of the individual fostered by books is reflected in Collins's discussion of Oprah's Book Club, the popular segment of American talk show The Oprah Winfrey Show launched in $1996 .{ }^{80}$ Collins argues that in selecting literary novels for her book club, media celebrity Oprah not only acts like a wise librarian who recommends 'choices, not products, as expressions of taste, not mere commerce', but she also focuses on their therapeutic value, providing information that defines 'reading as self-realization' ${ }^{81}$ Both Long and Collins argue that the interaction with the literary source is negotiated primarily on the emotional level, and I argue that a similar strategy is at work in Casella's novel, for example when Gloria reads Henry James's Portrait of a Lady (1881) and her reaction to and understanding of it is based on her ability to relate to the protagonist, as if Isabel Archer were a real person and her story had strong connections with Gloria's life. In turn, because we are presented with a text (James's novel) that is read and discussed by a fictional character in a fictional book (Casella's novel) that is eventually read by a real person, the boundaries between the reading experience and commentary become quite blurred, and so is the subsequent call for self-cultivation. Moreover, the dialogue

\footnotetext{
${ }^{78}$ Elizabeth Long, Book Clubs: Women and the Uses of Reading in Everyday Life (Chicago: University of Chicago Press, 2003), p. xi.

${ }^{79}$ Long, Book Clubs, p. 145.

${ }^{80} \mathrm{Jim}$ Collins, Bring on the Books for Everybody: How Literary Culture Became Popular Culture (Durham: Duke University Press, 2010), pp. 87-104.

${ }^{81}$ Collins, Bring on the Books for Everybody, p. 87 and p. 101, respectively.
} 
between readers, the fictional and real one, is achieved by means of a colloquial writing that acknowledges and simultaneously tries to demystify any literary hierarchy, a topic on which I shall return in Chapter 3 and Chapter 6. Casella's strategy is of particular interest because it shows a clear attempt at separating Gloria from her 'cousin' Bridget on the grounds of literary seriousness: indeed, as she diverts the focus from self-help to self-cultivation, she is making Gloria's story into a tale of empowerment that transcends generic boundaries.

Finally, in depicting the life of a single woman in 2001 Italy Casella opted for a less lively perspective than Fielding's: unlike Bridget, who is a middle-class, witty and educated person, surrounded by friends and living an exciting life, Gloria is truly a struggling, working-class woman. Overweight, over thirty, with little education and no professional ambitions, lost in a crowded metropolis, in one passage she defines herself 'una trenta-e-passenne di famiglia modesta, senza lauree né amici coi castelli [...] una single con poche prospettive, una scoppiata in tutti i sensi' ${ }^{82}$ I believe that this injection of self-effacing realism constitutes a very interesting deviation from the glitzy original model, because it not only offers the possibility of a more nuanced representation of ordinary single women against wider social backdrops, but it also could pay off enormously in terms of storyline and character development. ${ }^{83}$ Yet Casella does not take any risks and, going against her own intuition, downplays the realistic features brought in by choosing a female character who is a dropout, 'una

${ }^{82}$ Casella, Un anno di Gloria, pp. 129-30.

${ }^{83}$ In this respect, I should at least mention Carmen Covito's La bruttina stagionata (Milan: Bompiani, 1992), a novel that was widely praised by literary critics for its unconventional use of language and the ironic take on themes such as (plain forty-year-old) single women and their relationship with sexuality, career and self-esteem. Not a chick lit novel in the current understanding of the term, it is certainly one of the first examples of Italian fiction written by women that challenges conventional representations of single women. 
scoppiata in tutti i sensi', and giving her a predictable happily-ever-after finale, with Gloria achieving love, empowerment and professional success. True to the $U g l y$ Duckling fairy tale, while Gloria enters a lucrative modelling career (she becomes a plus-size model), the writing of Diario di una single, a meta-fictional account of her own experience as a fat single woman in a world of happy and thin couples is the liberating experience that empowers her. The merging of Gloria's original diary with the book she is writing serves to underline her newfound voice, as the following excerpt demonstrates:

[racconto] quanto sia duro essere sole in un mondo di coppie, ma anche quanto sia sbagliato attaccarsi a un uomo pensando che sia l'ultima possibilità di avere una vita normale $[. .$.$] e più scrivo, più mi sembra che$ tutto acquisti un senso. È una sensazione bellissima', ${ }^{84}$

At this point, it may be helpful to consider the character's double narrative in light of what feminist literary critic Susan Sniader Lanser (1992) has called a process of 'selfauthorization' ${ }^{85}$ Lanser argues that the female voice and the act of writing represent a woman's 'quest for discursive authority: a quest to be heard, respected and believed, a hope of influence, ${ }^{86}$ all of which come to the forefront in the passage quoted above. Indeed, if the original diary represents Gloria's quest to be heard and respected as a woman, her Diario di una single - which she eventually publishes - becomes her gift to all the women still struggling to find their own voice, whom she is now in a position to inspire. Furthermore, it is worth noting that it is only when she gains her own (authorial) voice that Gloria is able to find completion ('più scrivo, più mi sembra che tutto acquisti un senso') and eventually true love, whereas Bridget does not quite move

\footnotetext{
${ }^{84}$ Casella, Un anno di Gloria, pp. 178-79.

${ }^{85}$ Susan Sniader Lanser, Fictions of Authority: Women Writers and Narrative Voice (Ithaca and London: Cornell University Press, 1992), p. 7.

${ }^{86}$ Lanser, Fictions of Authority, pp. 6-7.
} 
out of her indecisive status. In doing so, however, from a stylistic point of view Casella reverts to the 'serietà assorta' that characterised traditional rosa narratives, and seems to consider chick lit's humour a less appropriate device for validating a tale of female empowerment.

Despite the mentioned shortcomings, $U A G$ proves to be a valuable case-study for the creation and promotion of Italian chick. As I mentioned earlier, Casella acknowledged Fielding's work but also claimed independence from it, which indeed surfaces at various stages throughout the novel, from Gloria's working-class background to her search for an authorial voice. Yet, the original elements she introduced remain mostly ornamental or fall prey to popular romantic clichés derived from the rosa tradition, and what could have been a clever take on an international bestseller struggles to find a cohesive identity. Casella's main weakness seems to lie in the fact that the innovative features she brings into the chick lit narrative do not have a function in the story other than a didactic one, which is reflected in the writer's struggle to balance seriousness and humour, colloquial language and traditional writing, popular media and literary novels. Taken together, all these elements betray a difficulty in combining the spontaneity of $B J D$ with didactic and moralising aims at the core of the rosa tradition. In fact, they show that, unlike Anglophone chick lit, in early 2000s Italy's popular women's fiction was still intrinsically 'serious', both in style and subject matter.

\subsubsection{Valentina compra tutto}

From what I have concluded so far, it might be said that any novel trying to emulate Fielding's bestseller would be doomed to fail. Perhaps this is the reason why Italian 
writers wanting to try their hands at chick lit moved away from $B J D$ and looked for other sources of inspiration. This is the case of Magnanini's Valentina compra tutto (2002), whose acknowledged model is instead Sophie Kinsella's The Secret Dreamworld of a Shopaholic, translated into Italian in 2000 as I love shopping. ${ }^{87}$ In an interview about her novel, Magnanini explained that, when creating her character, she was directly inspired by fellow chick lit writer Kinsella: 'Il personaggio era già stato creato in modo esilarante da Sophie Kinsella. Io non ho fatto altro che "adattarlo", renderlo credo più autoironico e imperfetto, fragile e insicuro... Valentina è una Becky in versione Paperino, insomma... più umana' ${ }^{88}$ Magnanini makes a remarkable observation here: unlike Casella, who seemed quite annoyed by the comparison with Fielding and claimed that she rode the wave just because it was a good way to promote her own book, Magnanini happily embraces her predecessor and points out the fact that she has 'adapted' Kinsella's character to make it, as we shall see, more down-to-earth. Magnanini's attempt at merging with the original model (rather than distancing herself from it) is what makes her book a more interesting interpretation of the chick lit canon in the Italian landscape.

Such an approach is consistent with Ken Gelder's analysis of popular fiction, which he sees as a field with its own characteristics and patterns. ${ }^{89}$ Gelder's work draws together the production, distribution and consumption of popular fiction in order to look into the complexity of the field and demonstrate the fundamental role that genres play in it. His reasoning focuses on the fact that genre fiction is both 'self-referential'

\footnotetext{
${ }^{87}$ Magnanini, Valentina compra tutto, p. 236: ‘[ringrazio] Sophie Kinsella per l'ispirazione'. Sophie Kinsella, The Secret Dreamworld of a Shopaholic (London: Black Swan, 2000); I love shopping (Milan: Mondadori, 2000).

88 'Intervista a Carlotta Magnanini', in Delirio.net, 31 August 2004) <http://www.delirio.net/default. asp?id=102> [accessed 28 June 2008].

${ }^{89}$ Ken Gelder, Popular Fiction: The Logics and Practices of a Literary Field (London and New York: Routledge, 2004).
} 
and 'self-reverential', that is to say, '[it] simply couldn't function unless its writers and readers had at least some knowledge about the genre in which they participate ${ }^{90}$ In a process of mutual endorsement, formal features are essential to allow both the reader's recognition and the writer's acknowledgement of that field. As Gelder maintains, generic rules are in fact used by writers as an umbrella under which they then develop various combinations. Following a similar line of thought, one could say that key to Magnanini's writing is her awareness of the genre's conventions. It is true that she replicates Kinsella's main character, that is, a twenty-something single girl living in a fashionable city (London and Rome respectively), working in the media industry (a financial magazine and a publishing house), obsessed by fashion and afflicted by overspending, and takes up typical chick lit features such as first-person narrator and humorous tone; however, she manages to avoid the 'copycat effect' by reworking these elements in a fairly creative way.

First and foremost, the book was marketed primarily as a shopping guide by Aliberti, a small publishing house born in Reggio Emilia in 2001 with the aim of promoting local writers. ${ }^{91}$ Not only was the book's subtitle 'una guida per lo shopping metropolitano a Roma, Parigi, Londra' explanatory enough; in fact, the back cover further expands this idea by downplaying the novel's plot and referring to the book as a catalogue and travel guide altogether, a 'delizioso Baedeker attraverso il mondo delle merci $[\ldots]$ un indispensabile catalogo $[\ldots]$ per sapere quali luoghi frequentare e quali acquisti fare a Roma, a Parigi e a Londra'. Thus Magnanini's book can also be seen as an adaptation of the iconic Baedeker guides, and it is filled with detailed maps that

${ }^{90}$ Gelder, Popular Fiction, p. 50.

${ }^{91}$ See the publisher's website, 'Aliberti editore - La storia' <http://www.alibertieditore.it/?page_id=7> [accessed 7 March 2011]. 
illustrate the location of important shops, restaurants and clubs mentioned in the story. In addition, Magnanini's 'booklet effect' is set to a tone that is halfway between private journal and review, to the extent that the writing is often reminiscent of a magazine article or a travel guide. As such, when she refers to a specific place in the narrative, regardless of its national or international location, the address is immediately given in brackets and italics, often together with the phone number as in the following example: '[a Parigi uno] non può vivere senza la cucina del Man Ray (34, rue Marboeuf, telefono 00331-56883636).${ }^{92}$ Moreover, when dining in a restaurant, the dishes Valentina orders from the menu are italicised as well, suggesting the kind of highlight a food editor would recommend. Lastly, a handy index at the end of the book lists all cited places, complete with contact details.

This narrative experimentation is indeed what differentiates Magnanini's book from its British counterpart, and I believe it is very effective in giving it a 'travel-guide' flavour. However, Valentina compra tutto was also promoted as a novel directly inspired by a chick lit bestseller already available in Italy, so the front cover hints at many visual elements of the Italian cover of Kinsella's book (such as the pastel colors, the cartoon-style design and the shopping bags), with a cartoon-style female forearm loaded with jewellery and handing over a bright-pink credit card in order to buy, readers would assume, the bags sitting in the background (Figures 4 and 5). In doing so, Magnanini's cover effectively suggests a mixture of entertainment, consumerism and overspending, the latter cleverly rendered with a credit card instead of cash.

\footnotetext{
${ }^{92}$ Magnanini, Valentina compra tutto, p. 95. A quick check through the phonebook proves the information correct.
} 


\section{LOVE SHOPPING}

\section{SOPHIE KinSELLa}
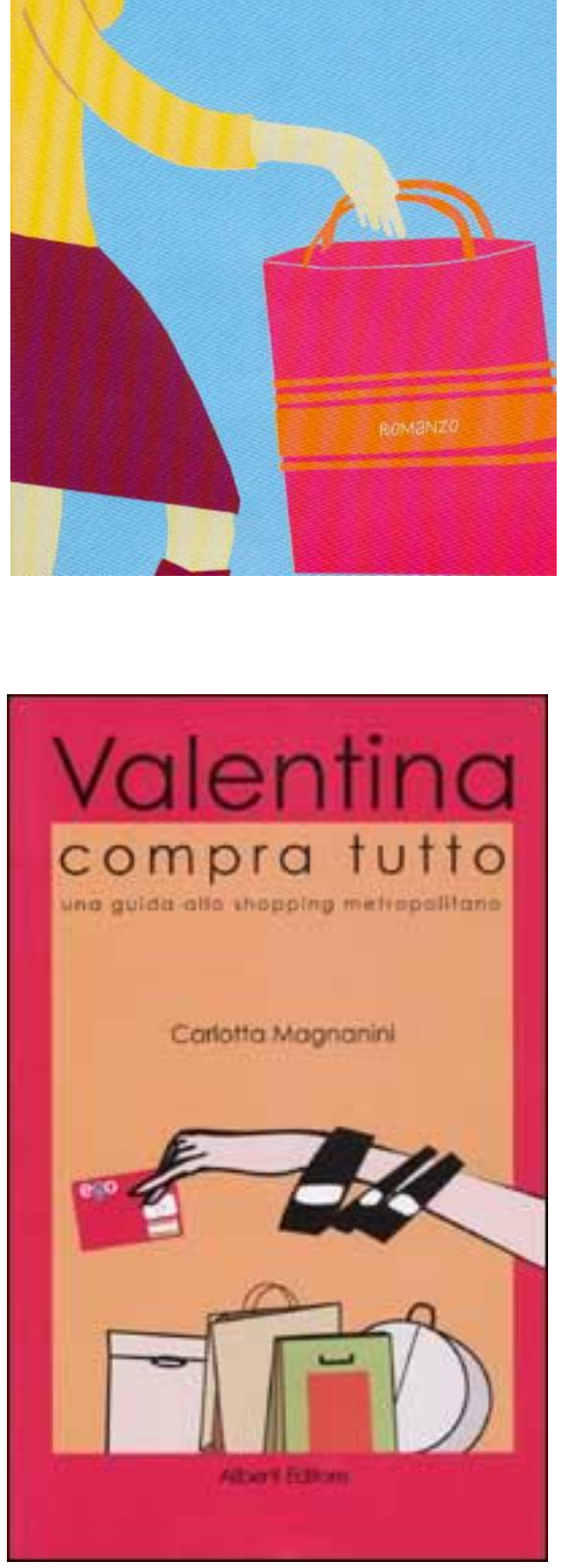

Figure 4. Cover of I love

shopping, 2000. (C) Mondadori.

Figure 5. Cover of Valentina compra tutto, 2002. (C) Aliberti 
Secondly, Valentina is a self-declared shopping-addict: 'Sono una shoppingaddicted. La cosa non mi ha mai creato problemi particolari, a parte quando sfugge al mio controllo. Cioè quasi sempre'. ${ }^{93}$ Certainly 'self-referential' and 'self-reverential' in Gelder's sense, this sentence suggests an interesting departure from Kinsella's model. Although both novels deal with fashion and consumerism as a means of identity and social status, Becky never refers to herself in the same way; in fact, she always stresses how she tries not to spend money. In other words, while Valentina comes across as ironically conscious of her addiction, Becky's addictive behaviour represents her as an insecure woman who 'engages in [...] consumption binges to assuage her anxieties'. ${ }^{94}$

Finally, it is worth noting that Kinsella focuses equally on Becky's financial troubles and her relationship with Luke Brandon, the handsome owner of 'the biggest PR financial company in London', ${ }^{95}$ whose heart she will eventually win. By contrast, Magnanini largely dismisses the romantic plot by having Valentina breaking up with her boyfriend at the very beginning of the story, and keeping her single throughout. Furthermore, The Secret Dreamworld of a Shopaholic depicts 'a consumerist fantasy world'96 detached from reality and pulls out a happy ending where Becky achieves both celebrity status and romantic fulfilment, but her Italian counterpart is given a less cheerful finale. Indeed, Magnanini introduces a cautionary tale in the narrative when Valentina unexpectedly reunites with her father, who had abandoned her at a very

\footnotetext{
93 Magnanini, Valentina compra tutto, p. 16.

94 Jessica Lyn Van Slooten, 'Fashionably Indebted: Conspicuous Consumption, Fashion and Romance in Sophie Kinsella's Shopaholic Trilogy', in Chick Lit, ed. by Ferris and Young, pp. 219-38 (p. 219).

Van Slooten's essay provides an interesting analysis of Becky's consumption habits in light of consumerism and commodity culture.

${ }^{95}$ Kinsella, The Secret Dreamworld of a Shopaholic, p. 24.

${ }^{96}$ Van Slooten, 'Fashionably Indebted', p. 237.
} 
young age. Now a rich and well-known PR executive in charge of a celebrated fashion agency in London, and a shopping-addict himself, he easily lures her into his glamorous life. In this context, it is worth noting that Valentina's father shares many of Becky's love interest's traits, insofar as he is wealthy, famous, and willing to help her to realise her inner potential (albeit not in finance like Becky but in the fashion business). The happy ending is apparently just around the corner, but after plunging into London's glamorous jet-set, Valentina soon realises that this shining façade hides nothing but hollowness: 'Sotto strati di velluti, kimono di seta e cachemire respira un vile pierre d'alto borgo, un jet-setter dei miei stivali che passa la vita a dosare strette di mano e sorrisi, carezze e pugnalate alle spalle ${ }^{97}$ Aware that she could eventually become like her father, Valentina flees to Rome, where she discovers she has been promoted to a top position in the publishing house. Still single, with her finances back on track, by the end of the novel Valentina is not a shopping-addict anymore, just a fashion-conscious woman.

The above observation is the grounds for a further comparison between the textual elements of the two novels. Kinsella's use of the first person is indeed very effective in portraying the 'secret dreamworld of a shopaholic', filled as it is with Becky's incessant daydreaming about fashion items and personal success. Such fantasies are often presented as castles in the air, as in the following excerpt:

Maybe I'll start my own chain of designer stores! God, yes. I'll be one of those people featured in articles about incredibly successful entrepreneurs. 'Becky Bloomwood [...] devised the innovative concept of Bloomwood Stores. Now a successful chain around the country, the idea came to her one day as she_- ${ }^{98}$

\footnotetext{
${ }^{97}$ Magnanini, Valentina compra tutto, p. 218.

${ }^{98}$ Kinsella, The Secret Dreamworld of a Shopaholic, p. 123.
} 
Just like a child fantasises about becoming an astronaut or a zoo keeper, here Becky daydreams herself into being a celebrated entrepreneur, complete with glamour and media exposure on celebrity magazines. Along with these acts of self-gratification, throughout the narrative Kinsella strategically places reports, statements and letters from Becky's banks about overdue payments, to which the protagonist predictably reacts with avoidance and even more self-gratifying daydreaming. From a textual point of view, the formality of such letters stands in vivid and effective contrast with Becky’s extreme attitude toward money; most importantly, as Van Slooten has rightly noted, they allow readers to 'live vicariously through Becky's shopping trips, without being troubled by the intrusion of reality'. ${ }^{99}$ In her novel, Magnanini acknowledges the same use of first-person narrator and conversational tone, as well as the protagonist's obsession with shopping and fashion daydreaming. However, she introduces an equally effective device into the narrative to comment on Valentina's behaviour and shows her literally hallucinating. Every time she is about to withdraw or borrow money in order to buy unnecessary fashion items, a warning figure materialises:

Pochi secondi e il vapore violaceo scompare come risucchiato da un mantice invisibile, rivelando lentamente una sagoma... [...] La figura si fa sempre più nitida: è un uomo elegantissimo, di mezza età, con una specie di turbante in testa e una giacca a coreana... Sembra David Niven, anzi no: è Peter Sellers vestito come l'indiano di Cocktail Party! [...]

'Milady, quanti prelievi ha fatto questo mese?' mi incalza, fumando da un lungo bocchino e continuando a fissarmi con occhi neri e penetranti. [...] 'Non crede sia giunto il momento di serbare gli scontrini?', 100

Absurd and patronising at the same time, these apparitions serve the purpose of making Valentina (and readers) temporarily aware of her situation. While this narrative device may appear less subtle than Kinsella's in satirising the character's behaviour, I

${ }^{99}$ Van Slooten, 'Fashionably Indebted', p. 237.

${ }^{100}$ Magnanini, Valentina compra tutto, pp. 67-68. 
believe it is in line with the double nature of the novel, which, as already mentioned, was promoted also as a shopping and travel guide. From this perspective, I would argue that the presence of creditors' letters and similar props could potentially undermine the reliability of the guide. Indeed, it seems that Magnanini's aim here is to educate her readers to healthy shopping habits (for example, by keeping track of their expenses by holding on to receipts), whereas Kinsella's world, ostensibly detached from reality, is free to play with consumption fantasies.

A further signal of the book's hybridism is in its internal organisation. Divided into five sections dedicated to the three glamorous cities of Rome, Paris and London, the plot departs from traditional beginning-middle-end storytelling and moves back and forth in time. The Paris section, for example, placed in the middle of the story, is in reality a flashback where Valentina recalls her holiday with former boyfriend Marco. This use of digressions, temporal shifts and commentaries is further expanded in each section, fragmented not only into chapters but also into micro-sections, each bearing an explanatory heading, such as 'Lasciatemi comprare', 'Bambini si diventa', 'Pavillon Puebla', 'Cucina francese', 'Swinging London', 'Papà (I)' and 'Papà (II)'. Thanks to this technique, readers advance through the narrative and at the same time are able to gather first-hand information about things to do and buy:

Il percorso è studiato dalla sottoscritta nei minimi dettagli: boulevard Saint Germain con sosta ad libitum da Sonia Rykiel (al 175), incursione veloce da Shu Uemura (proprio di fronte, al 176) per comprare qualche mascara, un po' di ombretti e piegaciglia, infine capatina da Reminiscence (22, rue $d u$ Four) per fare incetta di bijoux e profumi introvabili. Ovviamente Marco è convinto di essere diretto a Fauchon, tempio del palato in piazza de la Madeleine, per gozzovigliare tra caviale, champagne, gelatine e tè aromatizzati. ${ }^{101}$

${ }^{101}$ Magnanini, Valentina compra tutto, p. 100. 
Accompanied by an explicative map of the city, the above passage serves two purposes: from the storyline point of view it revolves around Valentina's trip to Paris and shows her obsession with fashion designers as well as her soon to be exboyfriend's less enthusiastic response; on the other hand, the shopping guide experiment embedded in the narration gains an international flavour, similar to the one Magnanini produces in the final chapter dedicated to London.

Far from complicating the narrative, Magnanini's hybridisation of chick lit and travel guide constitutes a very interesting experiment. Magnanini's commitment to the genre is openly stated from the start, as well as her willingness to adhere to its rules, leaving however space for original interpretation. Chick lit's staples like fashion, urban lifestyle and personal affirmation, along with a first-person narrator and a humorous tone, are simultaneously accommodated and revisited in their function, a process that is clearly visible, for example, in the integration of maps and reviews in the narrative corpus. The result is a novel that is neither challenging nor original in its plot, yet it is creative enough to gain a distinctive identity. Unlike Casella, who dismissed Bridget Jones's Diary but then fell short of elaborating her own take on the genre, Magnanini's ability to hold together the different fabrics of the narrative eventually delivers a convincing variation.

\subsubsection{Qualcosa bolle in città}

The last book I want to take into consideration as an example of early Italian chick lit is Vittorini's Qualcosa bolle in città (2004), the first (and only) Italian novel to have been published by Red Dress Ink (RDI). Established in 2001 as the dedicated chick lit imprint of romance fiction giant Harlequin Enterprises, RDI claimed to 'define, as well 
as offer books relevant to, the 21 st-century woman [and] leading women's fiction with attitude'. ${ }^{102}$ In 2002 RDI was launched in Italy thanks to Harmony, the already existing joint-venture between Harlequin and Italian publisher Mondadori, and introduced the Italian readership to well-established chick lit authors such as Sarah Mlynowski, Sarah Tucker and Melissa Senate, whose See Jane Date (2001) was translated as Cercasi uomo last minute two years later. ${ }^{103}$ In presenting the genre to the Italian market, editorial director Laura Donnini emphasised its innovative nature (compared to the traditional romance fiction published by Harmony), its role as social commentary and the new and younger readership it was attracting:

[...] donne più giovani, tra i 20 e i 40 anni, che possibilmente vivono in grandi città, alle prese coi problemi di tutti i giorni: carriera, fidanzati, essere single, ecc. Si tratta di tutte scrittrici nuove [che] esprimono la loro esperienza, in maniera ironica e frizzante. In Italia ci sono milioni e milioni di single. Questi libri, quindi, sono uno specchio della società di adesso. ${ }^{104}$

Likewise, a couple of years later the new editorial director Alessandra Bazardi pointed out the 'single attitude' of chick lit novels, which she defined as 'quella predisposizione a pensare in single indipendentemente dall'essere single o in coppia', ${ }^{105}$ suggesting that the genre's own identity was indeed to be found in the lifestyle it depicted rather than in the characters' sentimental relationships.

In this context Vittorini, who at the time was working as editor for Harlequin Mondadori, after a conversation with American chick lit writer Sarah Mlynowski came

\footnotetext{
${ }^{102}$ Harlequin Enterprises, 'RDI Writing Guidelines', <http://www.eharlequin.com/articlepage.html? articleId $=558 \&$ chapter $=0>$ [accessed 28 January 2008]. RDI's publications ended in 2009; the guidelines have since then been withdrawn from Harlequin website.

${ }^{103}$ Melissa Senate, See Jane Date (Richmond: Red Dress Ink, 2001); Cercasi uomo last minute (Milan: Harlequin Mondadori, 2003).

${ }^{104}$ Wanda Marra, 'Harmony: E il romanzo diventa business', RaiLibro: Settimanale di scritture e letture, 2003 <http://www.railibro.rai.it/interviste.asp?id=68> [accessed 21 March 2009].

${ }^{105}$ Alessandra Bazardi, 'Accoppiate o single, è una questione di stile', Giornale della Libreria, 119 (2006), 44.
} 
up with an idea for a genuine Italian chick lit novel, which the editorial team of RDI eventually followed through:

L'autrice Red Dress Ink Sarah Mlynowski era in Italia per promuovere il suo primo romanzo, ci siamo dette che sarebbe stato interessante avere un Red Dress Ink ambientato in Italia, sulla vita italiana, così ho deciso di provare a scriverne uno. Non è stato però facile ottenere il permesso a essere pubblicata da Harlequin Enterprises. Ma alla fine ce l'ho fatta. ${ }^{106}$

The unusual presence of a genuine Italian novel in the imprint, which Vittorini herself acknowledges in the above passage, attracted the attention of international media, reaching the pages of the New York Times. In 2004, the American newspaper featured an article about the first Women's Fiction Festival held in Matera (Italy), which was sponsored by the Italian branch of Harlequin and saw international editors and writers discussing the European national markets for romance fiction. Among other things, they all underlined 'trendy upstarts like chick lit' as particularly successful in Italy: 'Italians [...] have taken to chick lit, the post-Bridget Jones literary phenomenon, and Italy has been the strongest foreign market for Red Dress Ink, Harlequin's chick lit imprint' ${ }^{107}$ The article drew particular attention to Vittorini's book:

This summer, the Italian unit published Camilla Vittorini's 'Qualcosa Bolle in Citta,' ('Something's Boiling in the City'), about a young woman living in Milan "with a single attitude." It is one of the few times that Harlequin has published a writer outside of its roster of English-speaking authors. The Italian editors hope that if it does well here, it will be the first Italian book to be translated and published in English. [...] Harlequin published indigenous authors from time to time, but the publication of Vittorini's book could mark a real opening. (Ibid.)

\footnotetext{
${ }^{106}$ Womens Fiction Festival, 'Camilla Vittorini' <http://www.womensfictionfestival.com/cms/content/ view/76/113/lang,it/> [accessed 21 March 2009].

${ }^{107}$ Elisabetta Povoledo, 'Women's Fiction for Europe: "No Cowboys, No Babies"', The New York Times, 18 October $2004<\mathrm{http}: / / w w w . n y t i m e s . c o m / 2004 / 10 / 17 /$ business/worldbusiness/17ihtbooks18.html?_r=1> [accessed 21 March 2009]. The article also addresses the marketing strategies adopted by Harlequin Mondadori to launch the new imprint, such as merchandising tie-ins like moisturisers, instant coffee and jewellery brands. In this respect, see Maria Serena Palieri, 'Il Rosa e il Nero: E il caffè paga il libro', L’Unità, 08 October 2004, p. 22.
} 
The passage summarises two key concepts that are essential to any analysis of the presence of chick lit in Italy. Indeed, it reveals that after securing a place in the Italian market for the genre, Harlequin considered it successful and profitable enough to take the risk and publish an indigenous writer. Moreover, the possibility of a translation for such novels from Italian into English (and a subsequent distribution across the English market) was regarded as a feasible option; in fact, it was believed that Vittorini's book 'could mark a real opening'.

In reality the book, which according to the blurb on the inside flap portrays the life of Italian thirtysomethings 'con uno stile sagace, ironico e pungente', did not do very well on the Italian market and was never translated into English. Nevertheless, I believe it did mark an opening after all. In fact, this editorial experiment can be seen as a benchmark for the genre's development in Italy, for two main reasons: firstly, in the logic of the marketplace, Vittorini could count on the support of a major international publishing house like Harlequin to write her novel, whose successful landing in the imprint constituted an unprecedented factor in the local market and opened up a whole new set of possibilities for the international one. Secondly, from a literary perspective, unlike Casella and Magnanini who basically borrowed existing chick lit books and characters that were already well-known within the target audience and tried to pull them out of the generic context, Vittorini's approach worked the other way around: she chose the genre first, with its themes and conventions, and then built a character who could believably embody those conventions in the Italian context. Thus Vittorini put together elements such as the single woman with an attitude, the urban lifestyle, the humoristic tone and a strong attention to brand-named items and consumer culture. 
Financially independent and well-educated, the protagonist Sabrina works as a copy editor in Milan and has a charming boyfriend, Sandro, but the two split when he is reluctant to consolidate their relationship by getting married. The break-up is the narrative device that offers the chance to inject Sabrina's storyline with typical chick lit tropes such as heart-warming chats with supportive friends, shopping sprees, hangovers, and the obligatory one night stand. Eventually both Sabrina and Sandro realise that adult relationships do not depend on marriage but rather on people's 'attitude', and at the end of the novel the two reunite.

Although Vittorini tries hard to depict Sabrina as an independent woman juggling all the tropes of metropolitan singles, these elements are deployed in a 'pick and mix' style that results in a series of sketches where events follow one another like unconnected episodes. As such, the novel arguably recalls what Italian literary critics have dubbed a fenomeno di riporto, that is to say a marketing product artificially created from a foreign trend. ${ }^{108}$ The emphasis put on the concept of 'marketing product' is indeed what separates genuine genre fiction from a fenomeno di riporto: if we accept Stephen Neale's definition of genre as 'a set of expectations' in which repetition and differences equally contribute to the final work, ${ }^{109}$ we know that certain predictable elements must appear in every novel, but we expect them to be combined in a way that is unique to that specific story. In fact, the RDI Editorial Office provides fairly binding coordinates on how to write for its imprint, but it also asks writers to be creative, to 'set themselves apart from the average chick lit book. [...] Innovate, don't

\footnotetext{
${ }^{108}$ For the use of the espression genere di riporto in the literary debate, see Filippo La Porta, 'Contro il Nuovo Giallo Italiano', in Giulio Ferroni, and others, Sul banco dei cattivi, pp. $55-75$ (p. 65); Stefania Lucamante, ed., The New Narrative of the Giovani Cannibali Writers (Madison: Fairleigh Dickinson University Press, 2001), p. 16.

${ }^{109}$ Stephen Neale, Genre (London: British Film Institute, 1980), p. 51.
} 
imitate'. ${ }^{110}$ Thus my contention is that in Vittorini's case it is not so much the novel's predictability that disappoints; rather, it is the fact that it comes across as a 'romanzo redazionale', ${ }^{111}$ one that reproduces ready-made modules into an editorial concept with no significant variations.

This is evident for example in the fictional representation of Milan, the iconic city that embodies a prosperous Italian economy and glamorous lifestyle. As the book's title seems to suggest, the city's appeal should star as the co-protagonist of the story, in the vein of Bushnell's New York in Sex and the City; instead, despite the frequent references to upscale bars and restaurants, the depiction of the Italian city suffers from lack of creativity, as the excerpt below demonstrates:

[Milano] nonostante l'inquinamento, è una città affascinante. Perfetta per una trentenne con tanta voglia di scoprire il mondo e una vita di coppia un po'... particolare: non sono single, ma vivo da sola. ${ }^{112}$

In Sabrina's words, Milan is a chaotic yet charming city that suits a slightly unconventional thirtysomething career woman. As we can see, nothing in her description sets Milan apart from any other fictional setting. One may say that it is not the scope of the novel to flesh out a realistic depiction of the metropolitan landscape, but I would argue that because one of the genre's innovative features is the bond between contemporary single women and an urban lifestyle, a setting like Milan certainly demands a more convincing effort than a quick and stereotyped sketch. However, when Vittorini makes reference to specific places and locations, such as shops, restaurants or suburbs, these seem to be in line with what Joanne Knowles has

\footnotetext{
${ }^{110}$ Harlequin Enterprises, 'RDI Writing Guidelines'.

${ }^{111}$ Stefania Bertola, 'Che ossessione lo spot', Tuttolibri, 20 November 2004, p. 7. In the same year Bertola published her own Biscotti e sospetti, which I will discuss in Chapter 5.

112 Vittorini, Qualcosa bolle in città, p. 10.
} 
identified as a typical trait of British chick lit, that is, they are used to create 'a very specific socioeconomic experience and background' for the characters. ${ }^{113}$ In this respect, Vittorini takes a step further and provides readers with a detailed appendix at the end of the book (cleverly titled 'Milano come la Grande Mela. Ecco come se la morde Sabrina...'), where she reviews all the restaurants, cafes and shops named in the story. The section dedicated to the aperitivo, for example, reads as follows:

\section{Gli happy hour di Sabrina}

Per dimenticare una giornata di merda ci vuole un giro di aperitivi in compagnia di amici e colleghi.

\section{Yguana}

Dopo la riunione più catastrofica della mia vita, un cocktail fantastico e una serata decisamente imprevedible.

\section{Exploit}

La prima volta ci sono capitata per caso, vagando un po' scazzata... Poi ho conosciuto gente chicchissima, e da allora ci faccio spesso un salto.

Light

Musica, cibo, drink. Ma quello laggiù chi è? Decisamente un BEL VEDERE...

\section{Penguin}

La domenica sera l'aperitivo si prende qui. ${ }^{114}$

The list of bars where Sabrina enjoys Milan's famous 'happy hour' displays cool people, fantastic cocktails, nice food and music, and delivers an image of a glamorous urban lifestyle for single women in Italy that is clearly based on the one promoted by HBO's TV show Sex and the City - as the association between Milan and the Big Apple would suggest. But it is the section dedicated to 'La domenica con Sabrina' that points right to the character's 'attitude':

\section{La domenica con Sabrina}

Per rimettersi dal sabato sera cosa c'è di meglio di un brunch con gli amici?

\section{Le Biciclette}

Primo, secondo, contorno... che palle! Nel brunch mangio quello che mi pare, nell'ordine che preferisco. Il brunch è come me: senza regole.

\footnotetext{
113 Joanne Knowles, 'Material Girls: Location and Economics in Chicklit Fiction, Or, How Singletons Finance Their Jimmy Choo Collections', Diegesis, 8 (2004), 36-41 (p. 37).

${ }^{114}$ Vittorini, Qualcosa bolle in città, p. 191.
} 


\section{Fiori Oscuri}

Solo un brunch qui può salvarmi da questa domenica deprimente fra famigliole e bambini stranazzanti... ${ }^{115}$

The traditional Sunday family lunch, with its formal rituals, is crankily dismissed as outdated and replaced with the much more trendy 'brunch', the combination of breakfast and lunch to which Italians are just becoming accustomed. Vittorini here brings to light chick lit's relationship between glamorous metropolises and women's 'single attitude' by creating a young and hip Italian who lives and enjoys everyday situations borrowed from Anglophone media culture and is unwilling to put up with local traditions that she perceives as boring ('che palle') and annoying ('famigliole e bambini starnazzanti').

In this context, style and language offer the chance for some interesting observations. Much like Casella's and Magnanini's, Vittorini's style is half-way between real-time diary and stream of consciousness, with emails or messages embedded in the text, as well as to-do lists and other narrative devices, but when compared to these other writers it is clear that Vittorini strives to capture and reproduce the tone of chick lit novels written in English. Given the fact that the editorial team at RDI were considering the option of translating the novel for the British and American market, Vittorini, an editor herself, was certainly writing with translation in mind. In this context, I would highlight the fact that she has effectively deployed one of the key features of the genre, that is, the 'voice', a task that neither Casella nor Magnanini seem to have accomplished to the same extent. As the RDI guidelines state, '[T]he voice is where the heroine's personality really shines through.

${ }^{115}$ Vittorini, Qualcosa bolle in città, p. 190. 
$[\mathrm{H}]$ ave fun with it', ${ }^{116}$ and indeed Sabrina's voice successfully transfers the upbeat tone of Anglophone chick lit to the Italian text through everyday colloquialisms and juvenile jargons. For example, there is an abundance of interjections and particularly expletive attributives and 'bad language', as we have seen in the excerpts quoted before ('una giornata di merda'), alongside with variations such as stronzaggine, cazzate, rincoglioniti and so on; also, jargon like scazzata (annoyed), incazzosa (heated) and fighetti (wealthy young people) recur frequently throughout the novel. By no means experimental or innovative, with its standardised Italian influenced by mainstream media, all these elements represent however a considerable and interesting shift from the formal language and syntax of traditional popular romance toward chick lit's orality and informality, which both Casella and Magnanini did not fully acknowledge. Unfortunately, because Vittorini's writing is not well integrated into, or supported by, the narrative and generic frameworks, her linguistic and stylistic solutions often come across as forced and ultimately lose their innovative potential.

\subsection{Conclusion}

The three books I have discussed in this chapter help understanding the 'making of' Italian chick lit, giving a clear example of how and why global commercial genres produce different and sometimes contrasting hybrids locally. By taking successful chick lit bestsellers as the primary source of inspiration, each of the three Italian novels differs from the others not only in its relationship with the original genre, but also in the attempt at shaping equally compelling local versions. As we have seen, by looking at the ongoing dialogue that texts perform with each other and the audience in

${ }^{116}$ Harlequin Enterprises, 'RDI Writing Guidelines'. 
order to create meaning, intertextual analysis is particularly helpful in bringing to light not only the similarities but most importantly the differences within the chick lit genre, and thus providing us with the tools to assess each performance from both the textual and the generic point of view. My contention then is that the importance of these books lies not so much in their literary quality, but rather in the fact that in the early 2000s they played a significant role in establishing the basic coordinates for a worldwide commercial and literary phenomenon that publishers wanted to replicate in the Italian landscape. Magnanini's Valentina compra tutto, for example, deploys chick lit staples against the backdrop of travel and shopping guides, producing a text that simultaneously accommodates and revisits both formats. Likewise, with regard to the rosa tradition against which these early Italian chick lit novels were playing, the intertextual relationship at work is evident in how, for example, Casella's $U A G$ tries to give chick lit's 'attitude' a coat of Italian serietà through an edifying tale of selfempowerment.

The perfect case in point however is Vittorini's Qualcosa bolle in città, the first Italian chick lit in its own right. Endorsed by publishing giant Harlequin Enterprises, this novel brings to the forefront what is at stake when adapting mass-market fiction into an indigenous market. On the one hand the local production must tie in with the international franchise (RDI in this case), and thus it demands clearly identifiable similarities; on the other hand, it needs to dialogue with the specific cultural and social identity of the target audience, bringing in some degree of difference. While Vittorini accomplishes the former, her shortcomings with regard to the latter constitute the ground on which subsequent publishers would re-tune the experiment. From this 
perspective, Newton Compton's Anagramma represents the natural evolution of RDI's attempt, insofar as it constitutes a better orchestrated approach to the genre. In the next chapter I will examine precisely how Anagramma editors, by means of a specific imprint, star-authors and more liberty in terms of plot and writing style, carried out a reconfiguration of the genre that answered the audience's need for 'cultural proximity in cultural goods'. ${ }^{117}$

${ }^{117}$ Straubhaar, 'Beyond Media Imperialism', p. 39. 


\section{CHAPTER 3 - Consolidating the genre: Federica Bosco's 'trilogia di Monica'}

\subsection{Introduction}

In the previous chapter I discussed some examples of early Italian chick lit that helped Italian publisher to lay out the tools for building and replicating in the domestic market the success and appeal of a foreign popular fiction genre. When looking at the features of these novels, the complexities of transferring British and American popular narratives to the Italian setting become immediately apparent, particularly in terms of addressing the specific cultural and social identity of the new target audience. As I have explained, the books' derivative nature is often far too evident to generate a real interest not only in terms of readership response, but also from the perspective of what these texts can actually say about women's popular fiction in contemporary Italy.

However, my contention is that, rather than holding back the development of Italian chick lit, such shortcomings created the basis for other publishers to reconfigure the genre in Italy. Discussing the 'sentimentalismo romanticheggiante' of many contemporary novels, characterised by nostalgic and often unconvincing views of love and sentimental relationships, critic Gianni Turchetta highlighted a number of texts and authors that, by contrast, were able to look at the same themes in more innovative terms, particularly through the lens of irony. ${ }^{1}$ In particular, Turchetta filed Federica Bosco's debut novel Mi piaci da morire $(2005)^{2}$ under the chick lit genre, de facto acknowledging its presence in Italy. Although he described the novel as a 'libro esile'

\footnotetext{
${ }^{1}$ Gianni Turchetta, 'L'amore come sentimento. L'antidoto della tenerezza', in Tirature 06, ed. by Vittorio Spinazzola (Milan: Gruppo editoriale il Saggiatore/Fondazione Mondadori), pp. 24-32 (p. 26).

${ }^{2}$ Federica Bosco, Mi piaci da morire (Rome: Newton Compton, 2005).
} 
where all the generic tropes were blatantly played out, he conceded that the ironic vein in which Bosco delivered them was a stylistic element interesting enough to set it apart from the crowd. ${ }^{3}$

This chapter is therefore dedicated to Federica Bosco, whom critics of the genre, and readers alike have crowned the queen of Italian chick lit. After a brief overview of Bosco's publisher Newton Compton, I will look more in detail at the imprint Anagramma, currently leading Italian chick lit, with a particular focus on its paratextual features. As I have argued in previous chapters, chick lit is a genre tightly entwined with its paratext, in particular the book covers, and I will show how Anagramma publications are both traditional and innovative with regard to the cultural and visual impact of the chick lit genre in and for the Italian market. In the second part of the chapter the attention shifts to Bosco's so-called 'trilogia di Monica': Mi piaci da morire (2005), L'amore non fa per me (2007), and L'amore mi perseguita (2008), ${ }^{4}$ which I consider a significant case study of Italian chick lit, that is to say, a commercial genre sustained by a wide release that successfully combines local and international features. Translated into Spanish, German and Portuguese, among other languages, the three books have sold more than 400,000 copies to date ${ }^{5}$ (something quite exceptional for Italian women's popular fiction) and are being constantly reprinted. This gives a clear indication not only of the prominence of the writer in the genre, but also of the readership's positive response.

\footnotetext{
3 Turchetta, 'L'amore come sentimento', pp. 28-29.

${ }^{4}$ Federica Bosco, L'amore non fa per me (Rome: Newton Compton, 2007); L'amore mi perseguita (Rome: Newton Compton, 2007).

${ }^{5}$ Newton Compton Editori website, <http://www.newtoncompton.com/index.php?lnk=600> [accessed 10 March 2010].
} 


\subsection{Newton Compton, Anagramma and the Italian marketplace}

Before exploring in detail Bosco's novels, let us look at the main features of Newton

Compton and Anagramma. Presenting the company to the international market at the

2009 Frankfurt International Book Fair, the catalogue for potential foreign buyers

opens with this statement:

Founded in 1969 [Newton Compton] was a pioneer in the paperback sector, launching its famous series, classics of non-fiction, fiction and poetry, at very competitive prices. [...] In 40 years on the Italian publishing market Newton Compton has skilfully created a lively, modern image through its selections, which have always been alert to the youthful audience, and its ability to use all the channels of distribution. ${ }^{6}$

The above passage outlines Newton Compton's position in the Italian market, highlighting its well-established status among readers and the cross-genre features of its catalogue. Two points in particular are noteworthy: first, the fact that from the very beginning Newton Compton had a strong focus on the paperback format and 'competitive prices', elements that bring together convenience and marketplace visibility; second, the emphasis put on the publisher's 'modern image' and its close attention to a 'youthful audience'. Moreover, the reference to the younger segments of the market as one of its main targets suggests an active interest in the latest literary trends, both for translations and local products. Indeed, the blurb continues:

[T] he publishing house has also embarked on Italian and foreign fiction, with three successful series: 'Nuova Narrativa Newton', which embraces gems of the thriller genre and contemporary horror along with the great novels of authors like the Nobel Prize winner Nagib Mahfuz; 'Anagramma', which includes the most lively and intriguing novels that have inspired unforgettable films such as Quei bravi ragazzi [Goodfellas] and Fuga di

\footnotetext{
${ }^{6}$ Newton Compton, Foreign Rights Frankfurt 2009 Fiction \& Non-Fiction (Rome: Newton Compton, 2009), p. 2.
} 
mezzanotte [Midnight Express]; and the very recent 'Vertigo', with the four colours of the most extreme fiction of today. ${ }^{7}$

Here the cross-media and cross-genres nature of the publisher is enhanced by the focus on Italian fiction, which helps defining Newton Compton as a publisher wanting to present a range of genres that can suit every taste, from Nobel Prize winners to horror and extreme fiction, but also committed to giving space to Italian writers.

The 2008 issue of Tirature includes an interesting article on the state of the publishing industry in 2006-2007. Based on the data gathered from the Italian publishers' trade association AIE (Associazione italiana editori) and the Italian National Institute of Statistics (ISTAT, Istituto nazionale di statistica), Newton Compton's profit showed an increase of $18 \%$ over that period, with 300 new titles equally divided between reprints and new releases. ${ }^{8}$ In a country like Italy, where three big publishing corporations are eating up half of the market, these are extremely good results for a relatively small publisher like Newton Compton. From this perspective, its fairly solid position in the market is certainly related to the multi-faceted offering, which has contributed to the creation of the publisher's fresh and modern image. This brings me to Anagramma, which in the 2009 catalogue was housing 'i romanzi più frizzanti e intriganti per lettori e lettrici che vogliono divertirsi e riflettere sull'amore, l'amicizia e la vita'. ${ }^{9}$ This sentence accurately reflects Anagramma's move toward women's fiction and chick lit in particular, whose typical marketing keywords on the international scene are indeed fun, love, friendship and life. The key year for this shift in focus is 2005, with the launch of Federica Bosco's first novel Mi piaci da morire.

\footnotetext{
${ }^{7}$ Newton Compton, Foreign Rights Frankfurt 2009, p. 2.

${ }^{8}$ Stefano Salis, 'Calendario editoriale', in Tirature 08, ed. by Vittorio Spinazzola (Milan: Gruppo editoriale il Saggiatore/Fondazione Mondadori, 2008), pp. 234-48 (p. 246).

${ }^{9}$ Newton Compton, Catalogo 2009 (Rome: Newton Compton, 2009), p. 2 and p. 22, respectively.
} 
Previously, Anagramma's backlist offered a mixed group of new and old writers from various literary genres who had become popular via successful cinematic adaptations, such as Bill Naughton (Alfie), Nicholas Pileggi (Wiseguy), Armitage Trail (Scarface) and Edgar Wallace (King Kong), and others drawn from women's fiction, such as Clare Dowling, Stephanie Lehmann and Carol Matthews, all well-known chick lit authors.

As such, it could be said that until 2005 Anagramma was a multi-purpose container for a broad spectrum of bestsellers and occupied a hybrid space in the marketplace. If Bosco's success was somehow unexpected, nevertheless it prompted the publisher to rebrand the imprint and rethink its role in the market: on the one hand, it encouraged the shift toward chick lit, which was already thriving in Italy but was still relatively under-marketed; on the other hand, building on Bosco's achievement, Anagramma became the designated space for Italian writers wanting to experiment with the genre. In the last couple of years the rebranding has gone so far that, although the imprint still includes many of the early titles, they are given less and less visibility. In fact, the catalogue now boasts Anagramma as the leader of a new galassia rosa, a term that recognises the multiple faces of popular romance and the rejuvenation of Italian romance fiction altogether, with chick lit held up as the epitome of this captivating transition: as the 2010 catalogues proclaims, Anagramma 'ospita i romanzi più freschi e accattivanti, soprattutto dalla galassia "rosa", 10

\subsection{Anagramma's paratext: marketing Italian chick lit}

While marketing campaigns have certainly played a fundamental role in promoting the rebranding of the series, Anagramma's visibility in the marketplace calls for a deeper

\footnotetext{
${ }^{10}$ Newton Compton, Catalogo 2010 (Rome: Newton Compton, 2010), p. 2.
} 
analysis, particularly in light of the space that it has given to Italian novels. While other publishers had already launched their own chick lit imprints in Italy, such as Sperling \& Kupfer's Pandora Shocking and Harlequin's Red Dress Ink, their approach to the genre had been relatively standardised. Following a worldwide trend, the majority of their titles were translations from English and American bestsellers, with little to no interest in Italian authors. In addition, because many of these publishers could count on a long-established status in the popular romance market, I would argue that they considered chick lit as a natural extension of their usual field, updated for a younger and more fashionable readership. Not surprisingly then, in order to promote the genre they simply replicated the paratextual features that identified it on the international stage, namely cover art: indeed, the covers of chick lit novels in translation focus on fashion and glamour, with an abundance of stiletto heels, trendy bags, cartoon silhouettes and bright colours. By contrast, Anagramma has actively sought to create an innovative look for its titles, one that would reflect its original approach toward popular romance and Italian chick lit in particular. In fact, because it had neither connection with big corporations nor a background as a romance publisher, Anagramma was less bound to the conventional repertoire, or rather, it was able to rework such a repertoire into a less imitative design.

In Chapter 1, I extensively discussed the paratextual elements of Anglophone chick lit in light of Gérard Genette's work on the paratext. In the following pages I examine the distinctive traits of Anagramma books; my analysis is based on Newton Compton's catalogues, particularly the 2009 and 2010 ones available online from the publisher's website. When looking at the latest Anagramma titles, the first thing that one notes is 
the preponderance of typical genre-evocative words such as love, friendship and shopping, for example L'amore non fa per me, La sindrome dello shopping, Il sexy club del cioccolato to name a few, yet a caption-style heading in plain and light typesetting somehow diminishes the weight of the title in relation to the cover art. In fact, it is the latter that captures the reader's attention thanks to good quality stock images with vivid colours that communicate a cheerful mood and that occupy the whole cover. The pictures are typically all-purpose flowers, shoes and hearts, or, more often, images that interact with the book's title, as in the case of Daniela Grandi's Il club dei pettegolezzi (2009), where a woman in 1960s hairdo is pictured juggling three telephones at once to deliver the idea of gossip and chitchat. Incidentally, it is worth noting that Grandi's novel was marketed as '[i]l primo esilarante, ironico e intelligente Sex and the City italiano'. ${ }^{11}$ In light of the rebranding of Italian popular romance fiction carried out by Anagramma, and more specifically its endorsement and promotion of domestic chick lit, such marketing strategy is commendable. The link to the American TV series, whose worldwide popularity and appeal have not decreased since its first appearance in 1998, becomes the culturally significant backdrop against which the publisher positions and markets Grandi's novel not only locally but also internationally. Indeed, a look at the catalogue for the 2009 Frankfurt International Book Fair tells us that the book has sold more than 10,000 copies locally and that it is 'the first hilarious, ironic and intelligent Italian SEX AND THE CITY'. ${ }^{12}$ Written in capital letters, the American TV show's title is clearly the focal point of the blurb: while the typographical emphasis aims at making the novel more enticing to

${ }^{11}$ Daniela Grandi, Il club dei pettegolezzi (Rome: Anagramma, 2009), book jacket.

12 Newton Compton, Foreign Rights Frankfurt 2009, p. 6. 
international buyers, it also draws the eye to the ongoing intertextual dialogue between different cultures and media.

The substantial disappearance of visual chick lit staples such as curly typesetting and cartoon-style covers gives a clear signal about Anagramma's take on the genre's paratextual features for the Italian landscape. Indeed, as I have argued elsewhere in this thesis, the cover design not only sustains the identification and placement of new genres in the market, but it also underlines the place that each text occupies in or outside the genre. Although chick lit as a genre undoubtedly remains at the core of the imprint, a great effort is made to avoid any obvious cliché that could put off potential new readers. In this respect, the packaging of the imprint is evident in the images that open the sections dedicated to Anagramma in the most recent catalogues. In 2009, readers were welcomed to Anagramma by three women in glamorous 1950s outfits, all perfectly groomed and sitting in what appears to be a waiting-room (Figure 6). The picture's dominant colour is obviously pink, and the tones are bathed in light thanks to brightness effects that delivers a chic and retro atmosphere. Likewise, the look of the three women, all white and differentiated only by hair colour (that is, a blonde, a redhead and a brunette), puts forward ideas of old-fashioned normative femininity and glamour: they appear absorbed in typical pursuits such as reading a glossy magazine (Vogue), applying make-up and looking for something in a handbag respectively. Alongside these visual elements, the copy in the middle of the page explains the nature of the series as 'per lettori e lettrici che vogliono divertirsi e riflettere sull'amore, l'amicizia e la vita'. ${ }^{13}$ One year later, the same copy is linked to a picture that

\footnotetext{
${ }^{13}$ Newton Compton, Catalogo 2009, p. 21.
} 


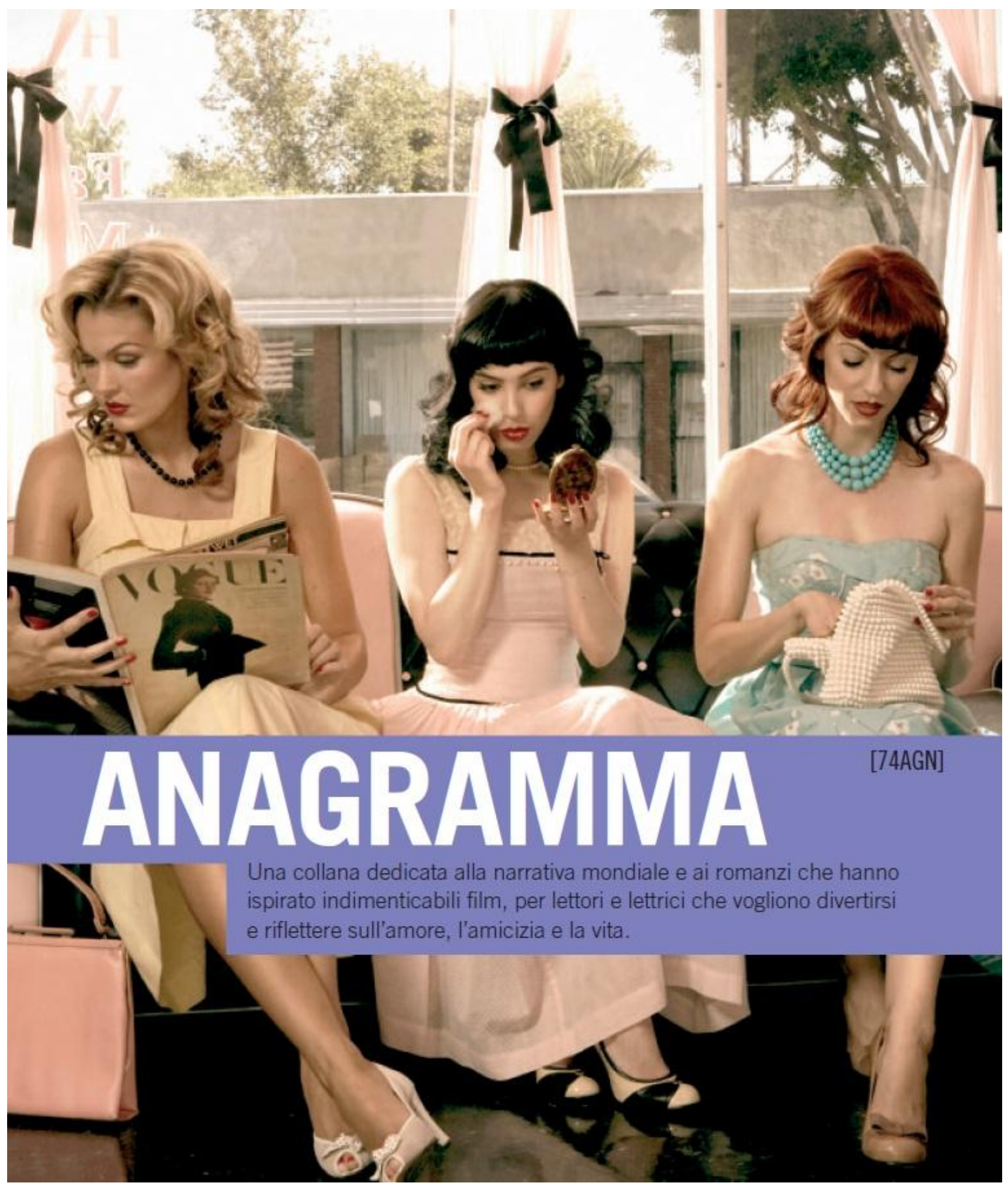

Figure 6. Anagramma promotional picture in Newton Compton's catalogue, 2009. (C) Newton Compton. 
dismisses sophistication altogether to build on ideas of female empowerment, assertiveness and self-awareness (Figure 7). The quirky image presents a brunette on the phone, with the index finger on her lips to invite silence; she is wearing a black corset and big hair curlers, and the surprised look on her face suggests that she has been caught in a private moment, perhaps while dressing up for a night out. This time the colours are more saturated, particularly the red (highlighted by the bright receiver and woman's lipstick), and the overall atmosphere is definitely bolder and assertive. Taken together, the two pictures indicate a move away from traditional popular romance and assess Anagramma in light of discourses of Anglo-American postfeminist media culture, particularly the ironic makeover of traditional femininity through feminine language and signifiers such as clothes, make up, and so on, which women ironically perform in order to deconstruct and negotiate their gender role. ${ }^{14}$ In this context, both pictures chosen for representing Anagramma's public face manifestly promote, each in its own way, an ironic reconfiguration and performance of femininity. At the same time, the copy's subtext strategically omits the chick lit label and welcomes a broader readership interested in universal themes such as love and friendship. In doing so, it applies a contemporary and modern gloss onto the Italian galassia rosa and successfully constructs an imprint that, in the context of entertaining popular genres, offers quality fiction with a focus on emotions. As we shall see, this mix of 'quality' and 'entertainment' will indeed occupy a peculiar place in Bosco's fiction.

\footnotetext{
${ }^{14}$ Stéphanie Genz, Postfemininities in Popular Culture (Houndmills, Basingstoke, Hampshire and New York: Palgrave Macmillan, 2009), pp. 86-94.
} 


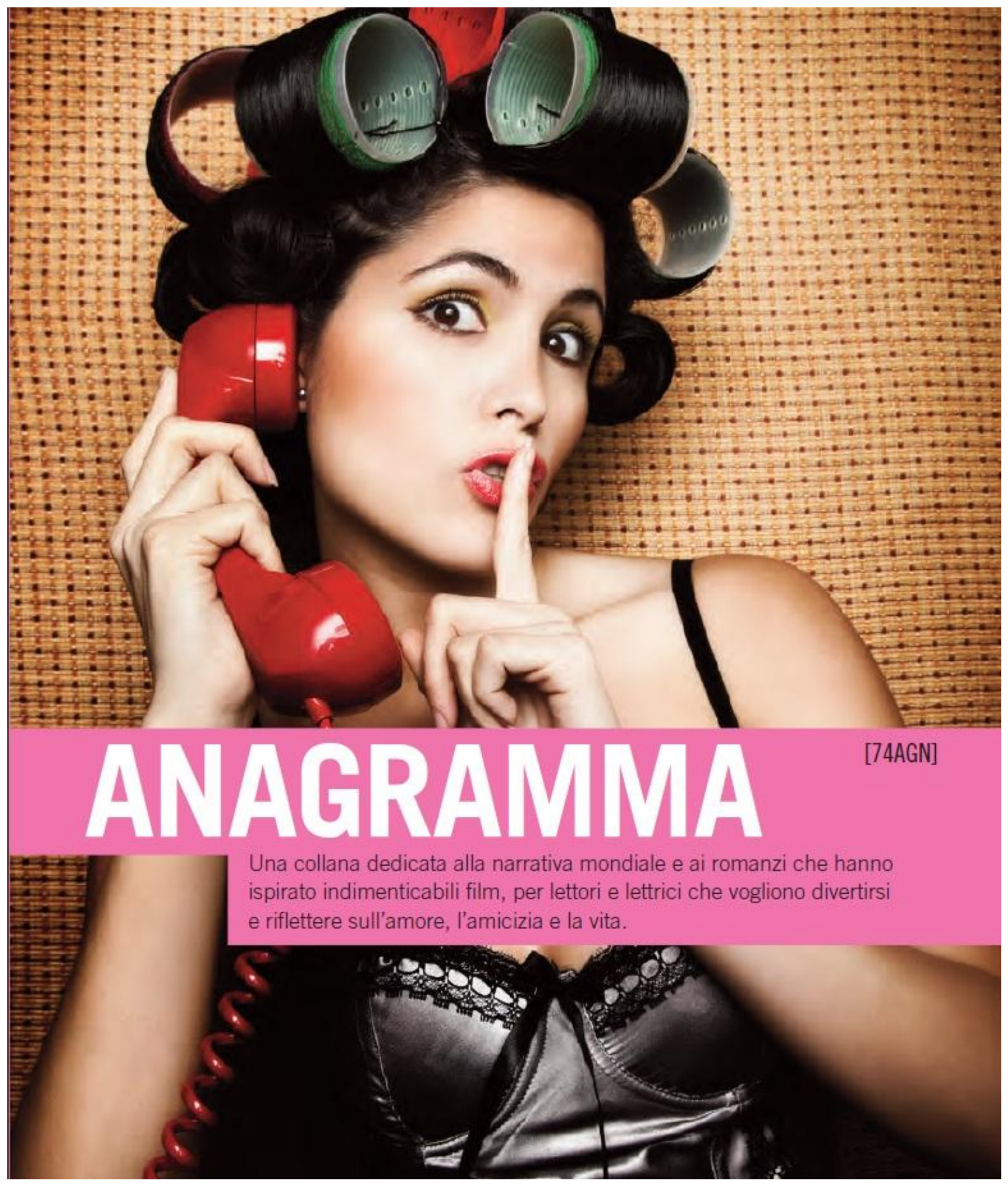

Figure 7. Anagramma promotional picture in Newton Compton's catalogue, 2010. (C) Newton Compton. 


\subsection{Federica Bosco: the 'queen' of Italian chick lit}

All the paratextual elements discussed above have been instrumental for the strengthening of Anagramma's position in the marketplace with regard to women's fiction and chick lit in particular, which in turn has fostered and encouraged the rise of a new wave of Italian writers who are experimenting with the genre. Among them, Anagramma's star writer Federica Bosco stands up today as the frontrunner of Italian chick lit, and her works have gathered a number of devoted fans who interact with the writer through the pages of her blog. Independent from the publisher's website but embedded in Bosco's own promotional website, this is the place where Bosco anticipates highlights of her latest production and writes about her daily life as well, inviting readers to comment and often thanking them or answer their questions. Updated on a regular basis and written in a loose, informal style that is predominantly upbeat and playful, Bosco's blog enhances the confessional narrative that is the central tenet of chick lit and creates a community where the writer and readers freely share their experiences with humour and irony.

Bosco's debut in the genre was quite impressive, especially for a writing that is typically overlooked by major Italian critics and media: according to Tirature, in 2006 her first two books sold more than 160,000 copies; by comparison, in the same year, Niccolò Ammaniti's critically acclaimed Come Dio comanda sold 270,000 copies, while Federico Moccia’s besteller Scusa ma ti chiamo amore reached 640,000 copies. ${ }^{15}$ Bosco's debut novel was then shortlisted for the 2006 Zerilli-Marimò Prize, a literary award organised by the Department of Italian Studies of New York University and the Italian Cultural Institute of New York and given to 'a new Italian work of

${ }^{15}$ Salis, 'Calendario editoriale', pp. 234-48. 
fiction deemed especially worthy of the attention of readers in North America and the English-speaking world. ${ }^{16}$ Although Bosco did not win the prize, being shortlisted was nevertheless a considerable achievement for a novice writer. More recently, in 2010 Bosco's latest work (S.O.S. Amore) came second at the 'Premio Bancarella', a prize annually awarded by a committee of librarians and booksellers for books, not necessarily Italian ones, of high literary merit and with significant sales figures published in Italy. ${ }^{17}$

Bosco's novels centre on single women in their thirties, in search of fulfilment both in their private and professional lives. In the last five years she has been a very prolific writer and has published six novels, a couple of short stories and two comical self-help manuals for young women on how to cope with sentimental break-ups, all under Newton Compton's Anagramma imprint. ${ }^{18}$ However, my analysis focuses exclusively on the so-called 'trilogia di Monica', not only because the three novels represent Bosco's most successful work to date, almost classics of the genre, but also because in following Monica's social and personal development, the books build a narrative pattern articulated enough to allow for more in-depth analysis. I will concentrate on

\footnotetext{
16 'Zerilli-Marimò Prize for Italian Fiction' homepage, <http://italian.as.nyu.edu/page/zeillimarimo> [accessed 10 March 2010]

${ }^{17}$ The winner of the 2010 edition was Elizabeth Strout's Olivia Kitteridge, Pulitzer Prize for fiction in 2009. Other shortlisted novels were Mimmo Gangemi's Il giudice meschino (Einaudi), Vauro Senesi's La scatola dei calzini perduti (Piemme), Rosa Mogliasso's L'assassino qualcosa lascia (Salani) and Bill James's Confessione (Sellerio). <http://www.premiobancarella.info/bancarella/news.php? mod=leggi\&id=171> [accessed 20 August 2010].

${ }^{18}$ Her seventh book, Innamorata di un angelo (Rome: Newton Compton, 2011), has been released in February 2011 and announces a significant change of direction in Bosco's production toward young adults fiction and paranormal romance. The first part of another announced trilogy, this novel is set in London and revolves around Mia, an outcast teenager who dreams of becoming a dancer at the prestigious Royal Ballet School. The story deals with themes such as teenage angst, death and suicide, and grippingly ends with the protagonist Mia in a coma, possibly dead. The book has received positive reviews from readers and critics alike; in this context, the setting suggests that this time the trilogy has been conceived for an international market since the very beginning, and it will be of great interest to see how the foreign rights acquisition will develop.
} 
two distinct aspects that I consider central to the critical analysis of Italian chick lit: first, from the perspective of genre fiction, the trilogy highlights how factors such as a dedicated imprint and character's serialisation have been instrumental to the affirmation of Italian chick lit as a genre and of Bosco as a writer in her own right; second, from a textual point of view, I look at the intertextual dialogue that these novels perform with Anglophone popular and media culture, as well as with canonical literary authors such as J.D. Salinger (1919-2010) and Daphne Du Maurier (19071989). Either directly or indirectly, at various stages during the narration these references help Bosco to build and acknowledge a shared background with the readership, contextualising her stories in a space that is both local and global, literary and popular, real and fictional.

\subsection{The 'trilogia di Monica': Mi piaci da morire (2005), L'amore non fa per me (2007) and L'amore mi perseguita (2008)}

Prior to discussing the elements mentioned above, I will provide a brief synopsis of the trilogy. The three books narrate the adventures of Monica, an Italian thirtysomething who has moved to New York City in search of a second chance. Right at the beginning of the first instalment Mi piaci da morire, she says: 'Sono venuta qui perché, come tutti quelli che vengono in America, ho un sogno nel cassetto e una dose vergognosa d'incoscienza, ma immaginavo che sarebbe stato tutto diverso: avrei avuto un lavoro pagatissimo in televisione, un sacco di amici fantastici e un ragazzo meraviglioso. Ho la tendenza fobica a vivere la vita come fosse un film [...].${ }^{19}$ Monica's naive idea of living in New York means enjoying a glamorous life and finding her true love, but in

\footnotetext{
${ }^{19}$ Bosco, Mi piaci da morire, pp. 10-11.
} 
reality the American metropolis turns out to be quite different from the iconic city she had experienced through media and popular culture: the novel she is writing is not progressing, she shares a shabby apartment with quirky flatmates and works as underpaid shop assistant for two grumpy old women at an antique shop. Her sentimental life is no less muddled, as Monica is still in love with David, who is getting married soon and with whom she has a clandestine affair. But when she meets Edgar, an older British gentleman, everything changes: not only do they discover a shared passion for books and for the American novelist J.D. Salinger, but Edgar is also a publisher and, after reading Monica's writing, he offers to publish her work. Soon the two fall in love and by the end of novel Monica appears to have fulfilled all of her dreams: she sells the rights for her book and she takes up Edgar's offer to move to Scotland, where she will work as an editor in his publishing house. Instead of confirming the traditional happy ending, however, the last line of the novel is not a declaration of everlasting love but a more prosaic 'Pronto, Monica? Sono David'. ${ }^{20}$ In the book's finale, Monica receives a phone call from her ex-boyfriend minutes before catching a plane to Scotland, an unforeseen narrative device that reinforces the comedic tone of the novel and acts as the cliff-hanger that establishes the serialisation of the character.

Indeed, the sequel L'amore non fa per me (2007) opens exactly where the previous novel left off, with Monica hanging on the phone with David, who tells her about his recent divorce after discovering that his wife is a lesbian. David's attempt to draw closer resurrects old doubts and feelings in Monica's heart, even though she seems to have everything a woman could want from life: Edgar's house in Scotland is in fact an

${ }^{20}$ Bosco, Mi piaci da morire, p. 186. 
old manor in a country village and a successful career lies ahead, together with a solid relationship with a mature man. Not surprisingly, however, reality turns out to be a far cry from everything Monica had dreamed of. Edgar is a workaholic obsessed by the memory of his deceased wife Rebecca, and Monica's relationship with him is threatened by his controlling mother. After a series of dramatic events, Monica painfully breaks up with Edgar and decides to go back to New York; once again, on her way to the airport she receives a call from David, with whom she has just had a one night stand, but she does not answer the phone.

This time, the open finale leaves readers on a sombre note, one that lays the groundwork for the character's maturation in the final (to date) chapter of the trilogy, L'amore mi perseguita (2008). Back in New York, a disillusioned Monica discovers that she is pregnant and decides to keep the baby despite the fact that she is alone, unemployed and does not know who the baby's father is. The pregnancy forces Monica to confront her anxieties and fears in order to secure a future for her child; at the same time, thanks to her creativity and newly discovered passion for vegan food, she transforms the shabby cafe where she works as waitress into a trendy and hip place. The novel ends with Monica, now both sentimentally and professionally rewarded, announcing the imminent birth of her child.

\subsection{Growing up, growing out: in search for an individual voice}

As we have seen, Bosco's trilogy covers all the typical elements of chick-lit: a thirtysomething single woman struggling with professional affirmation, a glamorous city and a range of personal issues and anxieties. Alongside the first person narrator, Bosco's writing style borrows chick lit's colloquial and humoristic register, which 
facilitates a sense of realism and engagement with the protagonist of the story. Since Bosco wanted to present a coming-of-age tale, the repeated presence of the same main character throughout the novels acts as a plot catalyst and provides narrative unity; at the same time, each novel follows a self-contained, linear plot and can be read independently so that readers do not need substantial knowledge of previous events to enjoy the narrative, a strategy adopted for example by Sophie Kinsella in her Shopaholic series. In this respect, in order to prevent readers who pick up the story in medias res from feeling too estranged, key characters' traits and relationships are each time introduced or recalled by means of reflections or textual explanations, as in the following excerpt from $L$ 'amore non fa per me:

Sono qui in piedi con la cornetta in mano e dall'altro capo del filo c'è quello che, fino a sei mesi fa, consideravo l'uomo dei miei sogni (anche se era fidanzato), che mi ha sedotta e abbandonata e, non contento, si è sposato con la suddetta fidanzata, per scoprire in viaggio di nozze che era lesbica. ${ }^{21}$

Placed right at the beginning of the novel, the expository nature of the recap is counterbalanced by the humorous tone, and it effectively introduces Monica's personality and background to old and new readers alike. Shortly after, a couple of dialogue-driven scenes further explain the characters motivations while providing plot advancement by launching Monica’s new adventure in Scotland.

Quite predictably, Bosco was initially marketed as the 'Italian Helen Fielding', a label that both the publisher and the writer herself were more than happy to exploit, as indicated by the biographical notes in Mi piaci da morire: 'Sogna di diventare ricca e famosa come Helen Fielding'. Indeed, Bosco's first-person narrative and her humour

${ }^{21}$ Bosco, L'amore non fa per me, p. 9. 
are certainly indebted to Bridget Jones's Diary, together with the awkward protagonist and a strong inclination towards self-mockery, all of which fostered a predictable marketing connection. After the success of the first novel, however, there was a significant distancing from the English model in terms of publicity and marketing. For example, while praise for Bosco quoted on the back covers of the first and second book reads 'È arrivata la Bridget Jones italiana' and 'Bridget italiane crescono' respectively, in the third one there is no such reference to the famous British character, suggesting a plea for autonomy for the home-grown chick lit. More specifically, the aforementioned reference to Fielding in Bosco's biography soon disappeared, replaced by notes on Bosco's personal life and interests (the names of her two cats, the fact that she practices yoga, and so on) and particularly on the success of her previous books, namely the number of copies sold and their translation into a number of foreign languages. The latter in particular highlights how the publisher wanted to stress the fact that the new-born Italian chick lit had become not only clearly identifiable, but it was also being successfully exported.

Meanwhile, Bosco herself began to claim some independence from the unwieldy Fielding: when a reporter asked her if she enjoyed being known as the 'Florentine Bridget Jones', she laconically replied: 'Would you?'22 Similarly, asked whether Monica could be considered the 'anti-Bridget Jones', Bosco's answer was surprisingly similar to Casella's mentioned in the previous chapter, inasmuch as they both separated their work from Fielding's and acknowledged the use of her world-renowned character for publicity reasons only:

\footnotetext{
${ }^{22}$ David Busato, 'Intervista a Federica Bosco', EuropaSera, 5 October 2007 <http://www.europasera.it/ vedi.php?cat=interviste\&id=71> [accessed 27 May 2010].
} 
Né anti né pro. È semplicemente un'etichetta che mi è stata data all'inizio, insieme con il lancio promozionale, forse per definirne a grandi linee il genere che ho scelto, dato che in Italia la Chick Lit (la narrativa rosa soft) è snobbata [...] Chi legge i miei libri sa che con Bridget Jones non hanno niente a che vedere con Monica, ma le etichette sono dure da eliminare. ${ }^{23}$

For the purpose of my discussion, three elements in the above quote are worth discussing: firstly, Bosco feels compelled to give her own definition of chick lit, which she seems to perceive as potentially misleading for the Italian audience, and describes it as 'rosa soft'. In his work on television culture, John Fiske argues that a 'genre spells out to the audience the range of pleasures it might expect and thus regulates and activates memories of similar texts and the expectations of this one' ${ }^{24}$ Indeed, Bosco activates the audience's memory with a clear reference to the popular Italian tradition, but she also addresses their expectations by drawing attention to the fact that chick lit should be read as a softened romanzo rosa, that is to say, less melodramatic and more light-hearted. Secondly, because however Italian chick lit was virtually non-existent at the time of her debut, Bosco admits that the association with a successful model had been necessary in order to promote the novel, emphasising how the international appeal of chick lit was instrumental in securing her a niche in the market. Finally, Bosco is confident that eventually her readership will be able to compare Monica and Bridget and work out the differences, indicating that Italian chick lit had become distinctive (that is, recognisable) and, as such, it had gained the right to be judged on its own merits.

\footnotetext{
${ }^{23}$ Silvana Mazzocchi, 'Monica, amori e avventure di una trentenne a New York', La Repubblica, 18 December 2008 <http://www.repubblica.it/2008/12/sezioni/spettacoli_e_cultura/passaparola-3/libribosco/libri-bosco.html> [accessed 20 January 2009].

${ }^{24}$ John Fiske, Television Culture (London and New York: Routledge, 1987), p. 114.
} 
By the same token, Bosco's search for autonomy would eventually border on pure irritation with the Fielding comparison, as loudly voiced in the final acknowledgments of the last instalment of the 'trilogia di Monica':

Infine vorrei approfittare di questo spazio per rispondere una volta per tutte all' eterna domanda: "Ma è vero che sei considerata la Bridget Jones italiana?". Il fatto di aver creato un personaggio come Monica, una trentenne ingenua e insicura, alla disperata ricerca dell'amore, fondamentalmente onesta e che usa l'ironia come salvagente, non ha niente a che vedere con il personaggio di Helen Fielding. Monica non conta le calorie, né le sigarette, e il suo unico problema non è quello di scegliere fra Hugh Grant e Colin Firth, ma quello di imparare a credere in sé stessa, dimostrare il suo valore e tirare fuori le palle. Insomma... la risposta è $\mathrm{NO} ! ! !^{25}$

Such a forceful rejection of Fielding's character stands out against the novel's incipit, where Monica defines herself a thirtysomething spinster who will die alone devoured by her cats, playing on Bridget's notorious fear of dying alone and being found halfeaten by Alsatians. Nevertheless, Bosco is very vocal in drawing attention to the fact that while Monica is a naïve thirtysomething who relies on humour and irony to cope with her anxieties, it does not necessarily mean that she is Bridget's carbon-copy. Quite the opposite, in fact: unlike Bridget's issues, Monica's are not mundane things like calories and cigarette intake, or having to choose between two equally attractive lovers (referring, oddly enough, to the male actors in the cinematic adaptation and not to the novel's characters); rather, Monica is searching for self-awareness and empowerment ('tirare fuori le palle'), facing a difficult path toward emotional strength and maturity that has nothing to do with the trivial entertainment of her British counterpart.

Gérard Genette's theory of literary paratext provides a useful approach to the understanding of Bosco's attitude toward the literary and cultural references to Helen

${ }^{25}$ Bosco, L'amore mi perseguita, p. 286. 
Fielding. As discussed in Chapter 1, the French scholar delineates two categories of paratext, namely 'peritext' (for example the book's title and cover ) and 'epitext'. The latter refers to those elements that are "not materially appended to the text within the same volume but circulating [...] in a virtually limitless physical and social space' ${ }^{26}$ furthermore, Genette continues, 'the epitext is probably in this respect particularly arbitrary, for many future readers get to know a book thanks, for example, to an interview with the author-when it is not thanks to a newspaper review or a recommendation by word of mouth'. ${ }^{27}$ Peritextual and epitextual elements are deeply entwined and this is well on display in Bosco's case, where Fielding's persona and work seem to belong to both spaces: her name on the biographical note and back covers puts her steadily within the paratext category, whereas the countless references made to her work in reviews and interviews belong to the epitextual materials. Yet, both serve the same purpose: to support the reception of Bosco's book, and reaffirm her unique position in the genre. Thus, cited at the beginning as viaticum for recognition, by the end of the trilogy Fielding's work is recalled - both in its printed and cinematic versions - only to be quickly dismissed. In what looks like a full U-turn, it is precisely the independence of Monica from Bridget that now upgrades Bosco and proves her authenticity and artistic value against Fielding's.

Likewise, the cover design and titles for the books, published within the space of three years, somehow help in visualising this process (Figure 8): from the blurred

\footnotetext{
${ }^{26}$ Gérard Genette, Paratexts: Thresholds of Interpretation (Cambridge: Cambridge University Press, 1987), p. 344.

${ }^{27}$ Gérard Genette, 'Introduction to Paratext', New Literay History, 22 (1991), 261-72 (p. 262).
} 

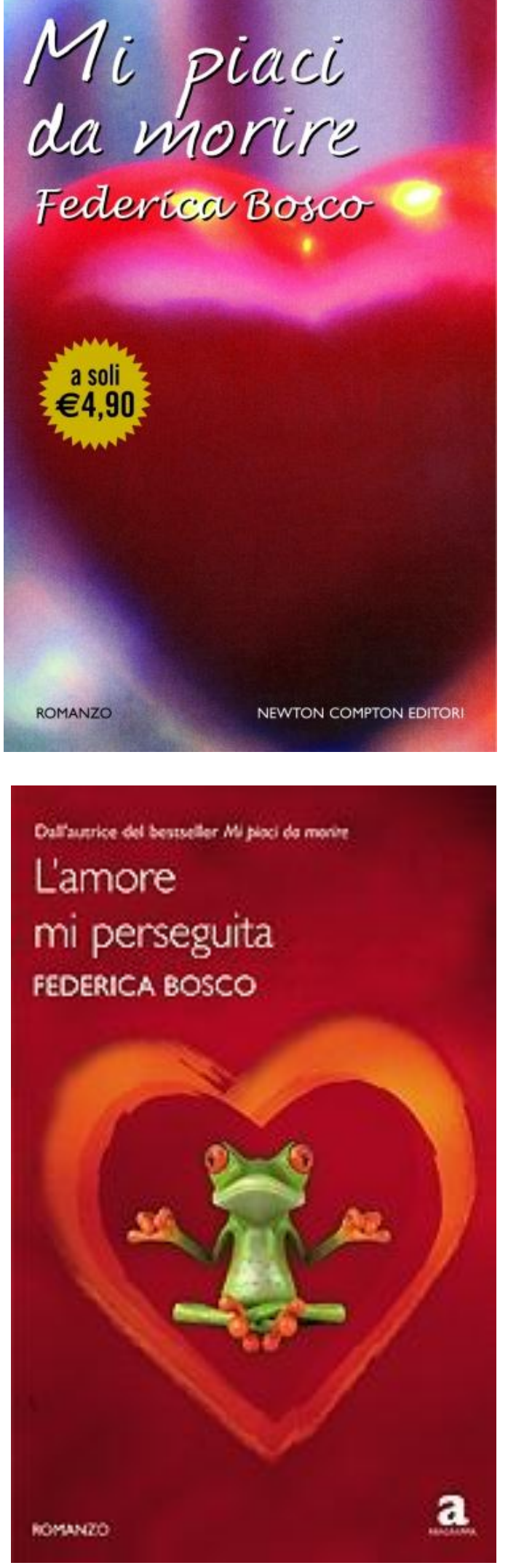

$>$ FEDERICA BOSCO

L'AMORE

NON FA PER ME

LAUTBCE ITALANA PIO ASATA DALE ITALSVE.

tiwe shose foccand fuviswwinen

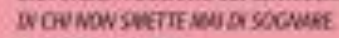

LA RePU⿴asea
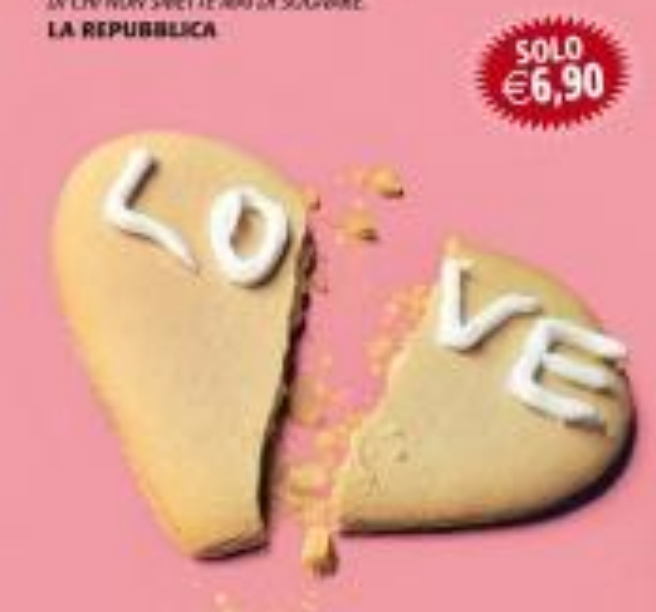

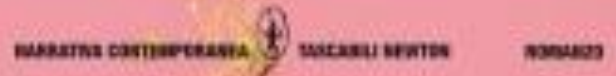

Figure 8. From top left, clockwise: covers of $M i$ piaci da morire (2005), L'amore non fa per me (2007) and L'amore mi perseguita (2008). (C) Newton Compton. 
photograph of a sugar-candy heart (Mi piaci da morire) to the broken heart-shaped biscuit (L'amore non fa per me) to the frog performing the lotus position inside a roughly pencilled heart (L'amore mi perseguita), the changing features of Bosco's chick lit could not be more emphasised.

The narrative reflects this gradual but steady detachment. The first book is pure entertainment built around Monica's character, with a simple plot and light-hearted situations and dialogues that tackle all chick lit tropes, from the clumsy protagonist to the flamboyant gay friend to the urban lifestyle, the latter emphasised by the setting in the USA and more specifically in New York City. The second instalment shows a more complex structure, not only in terms of storyline and character development, but also in language and style. Despite the humorous tone and the commitment to chick lit themes and tropes, including an impromptu interview with popular culture icon Paris Hilton, Bosco betrays higher aims for her character and brings topics such as depression into the narrative. As a consequence, the writing steers toward angst and self-exploration and deploys more of the confessional mode, a device that is fully developed in the third instalment, where the plot seems purely instrumental to delivering the character's maturation and offering a tale of self-empowerment. Back in New York, Monica is taken aback by the recent changes in her life and struggles to cope with them; thus her sense of displacement is immediately reflected in a different attitude toward the allure of the Big City:

Ed ecco New York e le sue mille luci: un enorme flipper dove tu sei la pallina che rimbalza fra i grattacieli e se non sei abbastanza veloce e abile a rimanere in alto, vieni inesorabilmente inghiottita nell' inferno dei bassifondi. 
Non mi stupisco se questa volta non ho il minimo entusiasmo per essere nella città più esaltante del mondo $[\ldots]^{28}$

This time around, New York is not the stunning metropolis where everything and anything is possible, even for an inexperienced Italian thirtysomething, but a hypnotising pinball machine that more often than not crushes people's dreams and hopes. It is in light of this new perspective that Bosco reframes Monica's story, one that brings to the forefront her quest for self-empowerment in a way that is not dissimilar to Casella's Un anno di Gloria, in the sense that it tries to give chick lit's 'attitude' a coat of Italian serietà through an edifying tale of female growth and maturity. Read for example the following passage, where Monica reflects on her past actions and behaviour:

Vedo una giovane donna che ha corso per più di trent'anni dietro a qualcosa di irraggiungibile che, per qualche attimo, ha creduto di afferrare: qualcosa di indispensabile come l'amore, fragile come l'equilibrio, unica come il sentirsi amati. [...] Non ho più voglia di mendicare amore, di cercare di essere all'altezza, di fare del mio meglio per essere la brava bambina che fa sempre i compiti, tanto alla fine non interessa a nessuno.

Sono sempre punto e a capo.

Da sola. ${ }^{29}$

Upon understanding that she has always been focused on pleasing the people around her, begging for love and affection, Monica eventually realises that she must start over and take care of herself. A few pages later she reassesses New York's legendary 'bright lights':

Le mille luci di New York viste da un taxi con gli occhi socchiusi, distrutta dalla stanchezza e con i piedi gonfi per aver lavorato otto ore, non sono affascinanti come quando sei a pezzi per aver ballato tutta la notte.

Adesso faccio parte degli invisibili, di quelli che vengono a New York per fare una vita decisamente peggiore di quella che farebbero in qualunque altro angolo del mondo, che si ammazzano per riuscire a pagare l'affitto

\footnotetext{
${ }^{28}$ Bosco, L'amore mi perseguita, p. 9.

${ }^{29}$ Bosco, L'amore mi perseguita, p. 99.
} 
abbassandosi a fare qualunque lavoro, ma che alla fine non vivrebbero da nessun altra parte, perché questo è l'unico posto che amano davvero e solo qui si sentono veramente a casa. ${ }^{30}$

Stranded after a long day working as waitress, in Monica's eye New York's allure does not reside in its glamorous party scene anymore, but rather in the fact that, despite living on the fringes of society, this is the only place where the young woman feels at home, and where she has the opportunity to reinvent her life from scratch. In this respect, the character's relationship with the urban space, one of the fundamental chick lit tropes, becomes instrumental in constructing Monica's newfound subjectivity. By focusing on her social and geographical displacement, the popularised, romanticised view of the city of New York is remapped into a more 'authentic' landscape in which Monica may be invisible, but not lost. Surely, Bosco opts for an inspirational awakening that is as conventional as it is naïve; nonetheless at this point in the narration it successfully achieves a goal that is textual and stylistic altogether. On the one hand, it introduces an appropriate validation of Monica's 'American dream', which so far had been quite juvenile and inconsistent throughout the trilogy; on the other hand, it brings into chick lit's light-hearted mood a touch of critical consciousness that is essential to Monica's maturation.

Indeed, in the third instalment the stress put on self-worth and agency is a blatant attempt to give Monica's story more depth, upgrading it from sheer entertainment to quality fiction. As such, Bosco's celebrated comical vein is reframed as well: exaggerated gags and self-deprecatory wit are still present, but they are confined to spaces that do not interfere with the main storyline, for example to secondary characters or amusing vignettes. It is only when the protagonist's maturation is

${ }^{30}$ Bosco, L'amore mi perseguita, p. 119. 
achieved that Bosco restores humour's prominent place in the narrative. This is exemplified in the finale of the novel, which deserves to be quoted at length:

'Non posso permettermi di regalarti un anello di Tiffany per il momento, ma ti giuro che appena posso te lo regalo, per ora ho solo... questo'. [Peter] mi porge una pallina di plastica con dentro un anellino di plastica per bambini.

Me lo metto all'anulare.

'È l'anello più bello che abbia mai visto!'

'Allora... è un sì?'

'Certo che è un sì!', lo bacio.

'Amore... dall'emozione te la sei fatta sotto?'

'No... mi si sono rotte le acque!'.31

A second before entering into labour, a heavily pregnant Monica receives a plastic engagement ring from Peter, a friend she had met on the Internet who turns out to be a sincere lover and enthusiastic would-be father of her baby. The above scene reintroduces chick lit 'attitude', comedy and romance in the fiction: while the declaration of love and formal engagement provide the conventional and tidy closure of romance novels, chick lit attitude tweaks it by replacing the luxurious yet predictable Tiffany diamond ring with a cheap plastic toy, a choice that Monica enthusiastically approves of. Likewise, the solemn atmosphere of the romantic gesture is rewritten in a slapstick scene where Peter believes that Monica lost control of her bladder when in fact her waters have just broken. Certainly the trilogy's conclusion does not stand out as particularly transgressive or innovative, neither in its linguistic fabric nor in terms of storyline; in fact, I would argue that it is quite conventional in its depiction of Monica's non-traditional lifestyle, which ultimately boils down to heterosexual romance within a nuclear family unit. Nevertheless, it is a significant example of how Bosco weaves together elements of traditional popular romance and

${ }^{31}$ Bosco, L'amore mi perseguita, p. 285. 
the new narrative trends set up by chick lit, so that her trilogy eventually becomes a 'rosa soft' that is both serious and entertaining.

\subsection{Popular culture and quality fiction: intertextual references and literary icons in the 'trilogia di Monica'}

As I have mentioned, what makes the trilogy interesting is not so much the writing style or the themes it approaches, but the fact that almost everything in it revolves around Anglo-American popular culture, and from this point of view Bosco's novels call for a more detailed analysis of cross-cultural and intertextual references. In commenting on the engagement between the appeal of the original model and the cultural and social identity of the local (Italian) audience, Turchetta has noted that the unabashed and deliberate use of references to American mainstream media culture is Bosco's preferred method of deploying chick lit's humorous tone: 'è talmente spudorato e voluto da trasformarsi in strumento di ironizzazione: sulla linea di una comicità semplice, ma del tutto intenzionale'. ${ }^{32}$ Rather than intentionally unabashed, however, I would define Bosco's technique inadvertently invasive. As I shall explain shortly, the ubiquitous process of creating content and appeal through virtual quotation marks ultimately threatens its alleged irony.

The influence of American popular culture on many aspects of contemporary Italian mass culture, customs and imagination started during and after WWII and has been increasing ever since. Silvia Cassamagnaghi for example has recently investigated how images and suggestions deriving from American media were received and interpreted in post-war Italy, discussing in particular how ideas of glamour, desire, beauty and

\footnotetext{
${ }^{32}$ Turchetta, 'L'amore come sentimento', p. 29.
} 
consumerism influenced the behaviour and aspirations of lower and middle-class Italian women during the $1950 \mathrm{~s}$ and $1960 \mathrm{~s} .{ }^{33}$ From a cultural studies perspective, David Forgacs (1996) has looked at the short-lived phenomenon of the paninari, a youth culture trend based on consumption and fashion that took place in the mid-1980s, as a poignant case study for the analysis of the rise and consolidation of cultural consumption in Italy. ${ }^{34}$ Created by middle-class youngsters in Milan, the paninaro lifestyle was rigidly codified and revolved around fast food outlets, the display of American and French brands such as Ray-Ban, Levis and Moncler and the use of a jargon made up of 'Spanish and Latin, as well as Italian and the Northern dialects'. 35 The product of media and consumer society, paninaro culture was however not limited to fashion statements; in fact, writes Forgacs, it quickly became a means of 'cultural distinction' and 'social differentiation', documenting a major 'turning-point in youth culture and values [...] towards a more consumption-based and style-conscious ethos' ${ }^{36}$ By the late 1980 s, the paninari trend was already vanishing, yet despite such a short lifespan their impact left indelible marks on Italian youth culture and language, some of which found their way into the literary production of the 1990s. This is most evident in the context of the giovani cannibali movement, young and innovative authors who looked at American popular genres in fiction, music and cinema, as well as global consumer culture, in order to build and negotiate new literary identities. ${ }^{37}$ As

\footnotetext{
${ }^{33}$ Silvia Cassamagnaghi, Immagini dall'America. Mass media e modelli femminili nell'Italia del secondo dopoguerra 1945-1960 (Milan: Franco Angeli, 2007).

${ }^{34}$ David Forgacs, 'Paninari', in Italian Cultural Studies: An Introduction, ed. by David Forgacs and Robert Lumley (New York: Oxford University Press, 1996), pp. 344-46.

${ }^{35}$ Forgacs, 'Paninari', p. 344.

${ }^{36}$ Forgacs, 'Paninari', p. 346.

${ }^{37}$ An extensive digression on the giovani cannibali movement is beyond the scope of this chapter; for a comprehensive analysis of the movement see Stefania Lucamante, ed., Italian Pulp Fiction: The New Narrative of the Giovani Cannibali Writers (Madison: Fairleigh Dickinson University Press, 2001),
} 
Stefania Lucamante and Elisabetta Mondello have noted, themes and languages from American culture were borrowed, reworked and integrated into the works of cannibali authors to translate youth alienation, displacement, homologation, gender identity and social status in 1990s Italy. ${ }^{38}$ Lucamante writes that the overwhelming presence of American media and consumer culture in the giovani cannibali narratives was not just superficial mannerism, but rather a deliberate intertextual strategy deployed to address issues of cultural globalisation and to reposition the "process of North Americanization of Italian culture' from the inside. Blurring the lines between literary and popular, writing and consumption, the giovani cannibali shaped a transformation in language and style that would influence future Italian writers enormously. ${ }^{39}$ In addition, Mondello notes the ephemeral life of many of these references directly lifted out of youth culture and jargon of their times, which were destined to become quickly outdated. Yet, she rightly observes that 'il problema della comprensione del testo è tutto del pubblico', ${ }^{40}$ highlighting an intertextual dialogue between writer and audience that, although based on the same sociocultural premises, leaves to the latter the task of not only correctly decoding the text, but also of activating it and keeping it alive.

To a certain extent, the same observations hold with regard to a popular genre like chick lit: as I have discussed in Chapter 1, the influence of consumer and media culture on themes, narrative structures, style and language constitutes a large part of chick lit, re-elaborated in ways that according to many scholars in the field encourage vicarious

which focuses on the works of authors such as Niccolò Ammaniti, Enrico Brizzi, Rossana Campo, Aldo Nove, Isabella Santacroce, Silvia Ballestra and Simona Vinci, among others. See also Elisabetta Mondello, La narrativa italiana degli anni Novanta (Rome: Meltemi, 2004).

${ }^{38}$ Lucamante, Italian Pulp Fiction, p. 25; Elisabetta Mondello, In principio fu Tondelli (Milan: Il Saggiatore, 2007), pp. 134-35.

39 Lucamante, Italian Pulp Fiction, pp. 24-26.

${ }^{40}$ Mondello, In principio fu Tondelli, p. 83. 
identification and critical evaluation alike. I believe that throughout Bosco's work there is a clear attempt, as transparent as it is uncomplicated, to address chick lit themes and ideas in a way that is indebted to the intertextual strategies deployed by the youth narratives of the 1990s. While Bosco's intertextuality certainly does not call for the same experimental connotations or disturbing tensions of the giovani cannibali, it holds cultural relevance none the less. Mondello talks about an 'immaginario stereotipato ma ampiamente diffuso che serve per definire abiti, atteggiamenti e comportamenti ${ }^{41}$ to describe how, for the writers of the 1990 s, references to particular movies, writers, and artists were pivotal in the shaping and strengthening of their literary identity. Bosco arguably follows the same pattern in her chosen genre, where the constant reference to the 'immaginario stereotipato' of Anglophone chick lit and mainstream popular culture serves a double purpose: on the one hand, it is the touchstone that validates Bosco's identity within the genre; on the other hand, it works as a key site for the encounter between global and local feminine identities. A case in point is the recurrent citation, explicit and implicit, of the iconic TV show Sex and the City and its themes across the trilogy to mark and evaluate Monica's journey. In the first instalment, Monica lands in New York because the traditional lifestyle she was leading in Italy, with a safe job, a fiancé and a mortgage, made her feel crippled rather than fully realised as a thirtysomething woman: '[ho mollato] l'Italia, un fidanzato quasi ufficiale, il mutuo e un lavoro sicuro a trent'anni per ricominciare tutto d'accapo'. ${ }^{42}$ Her real aspiration is to become a writer and lead an independent life just like the characters on the TV show; the novel she is working on, Il giardino degli ex,

${ }^{41}$ Mondello, In principio fu Tondelli, p. 141.

${ }^{42}$ Bosco, Mi piaci da morire, p. 11. 
much like Carrie's fictional columns contemplates the relationships between men and women. In the second volume of the trilogy, Monica gets a freelance job with the local newspaper in Scotland. When she is assigned to the gossip column, she plays on chick lit's self-deprecatory humour and enthusiastically comments: 'Sarò la Carrie Bradshaw delle Highlands!' ${ }^{43}$ In the third instalment, Monica's vicarious identification with Carrie turns into disappointment upon becoming aware of her delusional mixing of fiction and reality and the constant daydreaming of a life modelled on that of the protagonist of Sex and the City: 'immagino [Carrie] uscire con le sue Manolo e la sua pochette vintage per salire sulla limousine di Big. Pensare che ci ero cascata, credevo veramente che fosse possibile vivere a Manhattan facendo un lavoro part time'. ${ }^{44}$ The relationship with Carrie's glowing lifestyle comes full circle later on, when Monica lectures a group of spoiled teenage girls on how they should focus on self-esteem and the development of their own minds rather than on casual sex and appearance: 'Avete tutta la vita per vivere come in un episodio di Sex and the city, e vi garantisco che dopo un po' non è affatto divertente uscire tutte le sere per rimorchiare [...] è più importante come sei dentro di come appari fuori' ${ }^{45}$ Fully endorsed at the beginning of the trilogy, the positive engagement with discourses on consumer culture and popular postfeminism presented in the American TV show is eventually rejected as soon as Monica understands that, far from being glamorous, alluring and inspiring, Carrie's lifestyle is just trivial and superficial when compared to the issues that women face in real life.

If Monica's story-arc ultimately seems to cast a critical look on the 'immaginario stereotipato' that comes with American media culture from the perspective of an

\footnotetext{
${ }^{43}$ Bosco, L'amore non fa per me, p. 57.

${ }^{44}$ Bosco, L'amore mi perseguita, pp. 119-20.

${ }^{45}$ Bosco, L'amore mi perseguita, p. 174.
} 
Italian woman, the same observation does not quite apply to the trilogy as a whole, where Bosco borrows aplenty from various Anglophone media such as comics books, movies, songs and so on in order to generate identification and emulation, and to foster connections to everyday reality. While this approach suggests that the staggering prominence of these media in Italy's sociocultural landscape has not faded since the early 1990s, I argue that Bosco's wealth of cultural references encompasses little more than a series of reflexive allusions, fixed shorthand sketches appended to the narrative rather than incorporated into it. For example, the characters' features are usually described by comparing them to movie stars such as Brad Pitt, Katherine Hepburn and Whoopi Goldberg, along with fictional ones like Sally Spectra, Monica and Miss Rottenmeier, all of whom are very popular in the Italian context. ${ }^{46}$ Likewise, references to popular songs, comics books, cartoons, movies, and other popular media are used as metonymy in order to generate a quick connection to everyday reality, as in these excerpts from Mi piaci da morire: 'Fino a mezzora fa, ero convinta di aver conosciuto l'uomo della mia vita e invece è la versione maschile di Attrazione fatale' (p. 37); 'Mi sento come Kathy Bates nel film Pomodori verdi fritti quando grida “Towanda!", mentre distrugge la macchina di quella stronza che le ha fregato il posto nel parcheggio' (p. 76). Finally, in L'amore mi perseguita Edgar's deceased wife Rebecca plays explicitly on the character of the same name in Daphne Du Maurier's Rebecca (1939), which is a constant point of reference throughout the novel (albeit in

\footnotetext{
${ }^{46}$ Sally Spectra is a character from American soap opera The Bold and the Beautiful, one of the first to gain significant audience and ratings in Italy in the early 1990s; Monica is one of the characters of the sit-com Friends; Miss Rottenmeier is the stern housekeeper in Johanna Spyri children's novel Heidi (1880). In the late 1970s the Japanese animated series based on the Swiss novel was broadcasted on Italy's national TV, where it reached great heights of popularity, and 'Miss Rottenmeier' soon became shorthand for harsh and austere manners.
} 
the 1940 cinematic version directed by Alfred Hitchcock), with its setting in an austere country manor and Edgar's manipulative mother in the role of Mrs. Danvers.

As Fiske notes, intertextual knowledge 'pre-orient[s] the reader [...] by activating the text in certain ways', ${ }^{47}$ and from this perspective the examples mentioned above show that Bosco trusts the reader's knowledge and their ability to 'get' her popular culture references to 'activate' the text. But more often than not, Bosco's technique of cultural borrowings is one that rarely involves interpretation on the reader's end, as the situations and characters borrowed from Anglophone media culture are deployed as they are, confined into a narrative and contextual space that does not require further expansion or subtlety.

In this respect, an interesting feature to consider in Bosco's trilogy is the central position accorded to literary icon J.D. Salinger, who on various occasions acts as a fictional character and living epigraph. In Mi piaci da morire, Monica reveals the real reason for her move to New York: 'la ragione principale per cui sono venuta qui e che non ho mai detto a nessuno, è che voglio vedere dove abita J.D. Salinger. Il mio mito' ${ }^{48}$ This phrase introduces into the narration J.D. Salinger and from now on Bosco builds around his figure a large part of the novel. We learn that A Perfect Day for Bananafish (1948) is her favourite short story; that Salinger is a model for her not because of his literary merits, but because his themes resonate with her personal life: 'Nessuno come lui ha così bene interpretato il caos mentale, prima ancora che diventasse una moda, e io di caos mentale ne so qualcosa $;{ }^{, 49}$ finally, we find out that long ago Monica wrote him a letter which she now hopes to give him in person.

${ }^{47}$ Fiske, Reading Television, p. 108.

${ }^{48}$ Bosco, Mi piaci da morire, p. 24.

${ }^{49}$ Bosco, Mi piaci da morire, p. 25. 
For the purpose of my analysis, I want to focus on two particular elements of the paratext as defined by Genette: first, the 'epigraph-effect', or the citation of a literary text in order to add substantial and cultural value to the work in which it is included; second, the epigraph as 'a password of intellectuality', ${ }^{50}$ that is to say, when the chosen reference becomes a means for the author to seek literary authority. In Bosco's fiction, Salinger's epigraphic effect is rather obvious, as his most critically praised works, namely A Perfect Day for Bananfish and The Catcher in the Rye (1951), are included and cited throughout the story in the hope of supplying the novel with an intellectual furnishing that would add substantial quality to an otherwise standard piece of writing. But Salinger also operates as Bosco's own 'password to intellectuality': while the American writer is a source of constant inspiration for the fictional character of Monica, both personally and professionally, Salinger's authoritative figure serves also the purpose of laying out Bosco's own cultural background and literary models.

Yet, both Monica's and Bosco's responses to the works of Salinger appear to be purely emotional and have less to do with literariness than with personal involvement. Indeed, upon hearing about Salinger's death, Bosco wrote a lengthy and emotional post on her blog, in which she explained what the American author had meant to her and why she had decided to include him in her works:

Quando ho letto il Giovane Holden per la prima volta a circa 28 anni, in un momento della mia vita in cui niente andava come doveva e dove mi sentivo su una zattera alla deriva per la maggior parte del tempo, mi specchiai totalmente nel piccolo Holden: un ragazzino terribilmente sensibile, totalmente incompreso e disperatamente solo "dimenticato" in un college prestigioso dove tutti lo consideravano strano a cominciare dalla famiglia distratta e inesistente, mentre lui sperava in un abbraccio e un pò [sic] di calore umano [...] Avevo pianto un sacco e poi mi ero andata a leggere tutto il possibile su Salinger e la sua misantropia. [...]

${ }^{50}$ Genette, Paratexts, p. 160. 
In realtà, quello che ne veniva fuori era ben lontano dal dolce e vulnerabile Holden Caulfield, il ritratto dello scrittore era piuttosto quello di un uomo disturbato, difficile, anaffettivo, incapace di rapporti umani, intrappolato dal proprio talento che gli impediva di stare al di sotto della perfezione, diviso fra l'essere ebreo o cattolico, padre dispotico e pessimo marito. ${ }^{51}$

Bosco's interest in Salinger is negotiated almost exclusively on the personal level, as a powerful affinity that arises from his controversial persona: the father of heartbreaking characters like the young and lonely Holden Caulfield, the protagonist of The Catcher in the Rye with whom she immediately identified, and the misanthropic, troubled, emotionally-crippled man she gets to know through the plethora of unauthorised biographies that fed Salinger's mystical aura. Thus, it does not come as a surprise when Salinger himself materialises in the 'trilogia di Monica', taking the emotional connection to the next level. Indeed, the pivotal event in Mi piaci da morire sees Monica going on a pilgrimage to Salinger's isolated house in Cornish, where eventually she makes contact with the writer, albeit from a distance. Monica's lifechanging encounter is described as follows:

[È] lui, è J.D. Salinger. [N]on ha un'aria ostile, anzi sembra incredibilmente stanco. [...] Apre la lettera con una certa difficoltà, sembra che gli tremino le mani. Mi guarda per un lungo momento. Mi ricorda un vecchio leone, stanco ma fiero. Inclina la testa da un lato, poi mi sorride e pronuncia tra le labbra le parole 'Grazie a te', poi mi fa un cenno di saluto con la mano e se ne va. ${ }^{52}$

Arguably an exercise in suspension of disbelief, the passage - in which Salinger does not get upset or aggressive (as he was often reported to do with strangers and fans) but instead looks at Monica for a long time, nods, smiles, thanks her and retires into his house - constructs a sympathetic image of Salinger that reinterprets him and, more

\footnotetext{
${ }^{51}$ Federica Bosco, 'Goodbye catcher in the rye' <http://www.federicabosco.com/web/?s=salinger> [accessed 30 January 2010].

${ }_{52}$ Bosco, Mi piaci da morire, p. 128.
} 
importantly, aligns him to Bosco's own life and desires. The repeated use of the indirect object pronoun 'mi' with verbs like sorridere and fare un cenno di saluto stresses Monica's centrality in the scene, because while Bosco could have generically written 'sorride' and 'fa un cenno di saluto', this form would have diminished the significance of the moment for the protagonist. In depicting Salinger's interaction with Monica, it must be clear that he smiles at her and nods to her, so that the one-to-one relation emphasises the unique and privileged nature of the encounter. Furthermore, borrowing terminology from film technique, one cannot help noticing that Bosco alternates close-ups ('inclina la testa da un lato'; 'sembra che gli tremino le mani') and long shots ('mi guarda per un lungo momento') in order to dilate the narration and express the character's emotional turmoil. This technique is better understood against Bosco's own comment on the mise-en-scène:

[Q]uando ho creato il personaggio di Monica, non ho potuto fare a meno di immaginare un incontro fra il Gigante e la bambina, fra l'eroina e l'eroe, nell'intento di riuscire a restituirgli una dimensione umana, una dignità che, a quanto pare, la vita gli aveva tolto o non gli aveva mai dato. [...] Mi sembrava una cosa pazzesca, e in quel momento, mentre scrivevo, ero io che andavo a smascherare il Mago di Oz $[\ldots]^{53}$

Bosco's is the point of view of the fan, the 'excessive reader' described by Fiske as the one who engages with popular media texts in a much deeper degree than the 'ordinary' one, claiming a finer understanding of them. ${ }^{54}$ In a rather predictable process of identification, Monica/Bosco is thus able to 'see' that Salinger's larger-than-life figure (in literature and media culture alike) hides in reality a fragile and kind old man who has always been misunderstood. The final denouement happens in L'amore mi

${ }^{53}$ Bosco, 'Goodbye catcher in the rye'.

${ }^{54}$ John Fiske, 'The Cultural Economy of Fandom', in The Adoring Audience: Fan Culture and Popular Media, ed. by Lisa A. Lewis (London and New York: Routledge, 1992), pp. 30-49 (p. 46). 
perseguita, where Salinger makes a brief appearance toward the end of the story. Here Monica goes back to his house in Cornish to drop off an organic rye loaf that she has made in Holden Caulfield's honour. This time around, the atmosphere is drained of overcharged tones and steers toward comedy, when we see a grumpy yet very approachable Salinger inviting Monica into his house where she asks him to sign a copy of The Catcher in the Rye before taking a photo on her mobile phone like a teenage groupie. ${ }^{55}$

Despite the wishful thinking that permeates the narrative (arguably bound to provoke irritation and scorn in many critics), Bosco's real and fictional approach to Salinger calls for some observations. The first thing to note is that in both cases Bosco decidedly bypasses the literary status of Salinger's works and concentrates solely on his controversial image in popular media, addressing it by means of a narrative strategy that, just like Dorothy in L. Frank Baum's The Wizard of $O z$, eventually exposes the true nature of 'the man behind the curtain'. In order to do that, Bosco repeatedly claims closeness to Salinger's unspoken emotions, a closeness shared with the readers through the character of Monica, who combines identification and selfexpression and reduces the distance between fiction and reality. At the same time, such a strategy is overtly trying to introduce discourses of taste and culture within a genre women's popular fiction - that is overwhelmingly perceived as lacking in either. Indeed, Bosco's attempt at merging the popular with the literary through Salinger's persona is visible in the alternate use of dramatic and comedic tones that underline Monica's childlike interactions with him, yet Bosco's technique falls a little short in delivering the message. If in the first novel drama outweighs comedy, resulting in an

${ }^{55}$ Bosco, L'amore mi perseguita, p. 234. 
clumsy and quite awkward storyline, in the last instalment of the trilogy the steady shift toward comedy suggests a different awareness on Bosco's part: now a successful and well-established writer, she is less preoccupied with getting cultural and textual validation than delivering pure entertainment and extravagant gags. Indeed, in the middle of her conversation with Salinger, when Monica goes back to the circumstances that led to their first meeting, she notices his puzzled face and comments: 'Dio quanto suona assurda questa storia!', 56 simultaneously acknowledging and mocking the preposterous nature of the plot device. As such, the re-appearance of the iconic American writer seems to happen for consistency only, to the extent that it could have been anyone without making a significant difference in the text.

\subsection{Conclusion}

In this chapter I have looked at Bosco's novels from two different perspectives. First, I have analysed their success in the book market, discussing it as both the background for and the source of the active role played by Newton Compton/Anagramma in the rejuvenation and repositioning of Italian popular romance fiction in the marketplace. When chick lit in translation made its appearance on the Italian scene, Newton Compton paid attention to the specific cultural and social identity of the local audience and addressed the genre's conventional features in two ways: on the one hand, it acknowledged the longstanding tradition and multifaceted nature of Italian popular romance (the so-called galassia rosa); on the other hand, it rebranded the imprint Anagramma as the preferred space to promote local narratives through a series of paratextual elements that negotiated traditional conventions and contemporary

\footnotetext{
${ }^{56}$ Bosco, L'amore mi perseguita, p. 234.
} 
transformations, specifically in light of Anglo-American discourses of 'girl power' and Western postfeminist media culture.

Secondly, I have looked at Bosco's 'trilogia di Monica', her most successful work in the genre, analysing not only its role in the affirmation and consolidation of Italian chick lit, to the extent that Bosco is now a commercial brand herself, ${ }^{57}$ but also the textual and intertextual features that have framed these novels in a space that is local and global, literary and popular, real and fictional. Notwithstanding Bosco's ambition to produce a poignant tale of female empowerment, the trilogy is ultimately nothing more than a clever mix of chick lit 'attitude', comedy and romance for the Italian market.

In the next chapter I will discuss the works of Italian writers who have tried a different approach to chick lit, one that is of particular interest because of the focus on compelling issues relevant to contemporary Italian women, such as job security and their controversial relationship with financial independence and consumerism. Although some of these themes are present in Bosco's fiction as well, other writers make them central to their stories rather than just one of the secondary elements of the plot. As I shall demonstrate, their chosen themes also prove to be particularly significant in light of the ongoing debate on Western postfeminist culture, to which chick lit has been repeatedly connected.

\footnotetext{
${ }^{57}$ In 2008 Bosco wrote a short preface to William Shakespeare's tragedy Romeo and Juliet, which Newton Compton marketed at a younger audience alongside the more traditional edition. See Newton Compton, Catalogo 2009, p. 131.
} 


\section{CHAPTER 4 - Realism and popular postfeminism in Italian chick lit novels}

\subsection{Introduction}

In this chapter I continue my analysis of Italian chick lit by focusing on two novels that address some of the issues pertaining contemporary working women. Indeed, stories that focus on professional women constitute a well-established and identifiable subgenre in mainstream chick lit, the most famous example being Lauren Weisberger's The Devil Wears Prada (2003). ${ }^{1}$ In such novels the workplace is not just one among the various elements of the story but the main backdrop against which the whole narrative develops, casting a light on job accessibility and career options for women and providing a commentary on the frustrations, anxieties and desires related to these themes. ${ }^{2}$ With this in mind, my aim is to discuss the specificity of the Italian production, which borrows themes and tropes from the original chick lit canon (for example, the protagonist's job is always in publishing, communication and/or fashion, and the storylines focus on workplace dynamics or career concerns) and links them to identifiable frustrations and anxieties such as flexible labour and precariato.

To various degrees, all the novels discussed in this thesis present realistic undertones with regard to working women and career choices. Indeed, addressing the target audience's socio-cultural identity, these white, professional, middle-class fictional women include or talk at length about their struggles in the job market,

\footnotetext{
${ }^{1}$ Lauren Weisberger, The Devil Wears Prada (New York: Doubleday, 2003).

${ }^{2}$ Elizabeth Hale, 'Long-Suffering Professional Females: The Case of Nanny Lit', in Chick Lit. The New Woman's Fiction, ed. by Suzanne Ferriss and Mallory Young (New York: Routledge, 2006), pp. 103-18.
} 
sharing their thoughts and experiences with the readers. Yet two novels in particular take a closer look on more explicit themes such as job flexibility and unemployment, providing detailed accounts of their experiences: Rossella Canevari and Virginia Fiume's Voglio un mondo rosa shokking (2007) and Lisa Corva's Glam Cheap (2007). ${ }^{3}$ Published in the same year, both set in Milan, the two novels focus on women working in the media industry; these similarities constitute an interesting vantage point to see how each author represents and deals with topics such as flexible labour and precariato. After an overview of the Italian workplace context, where I take a look at the recent reforms of employment contracts and explain their impact on workers, particularly women, I will discuss Canevari and Fiume's novel and its approach to work flexibility in light of discourses on popular postfeminism and postfeminist culture. Because to date the representation of popular postfeminism has been virtually unexplored in Italian genre fiction, this chapter aims to take up the challenge and initiate a discussion, in the hope of encouraging further investigation. In particular, I will draw from the concept of 'choiceoise' outlined by feminist theorist Elspeth Probyn with regard to discourses of neotraditionalism and postfeminism deployed in popular culture and mainstream media in the early 1990s, depicting women 'choosing' the security of marriage and children over work and independence. ${ }^{4}$ In the second part, I will expand my analysis to Corva's novel, which presents a modern and atypical Italian female breadwinner to comment on discourses of self-affirmation and issues of

\footnotetext{
${ }^{3}$ Rossella Canevari, and Virginia Fiume, Voglio un mondo rosa shokking (Rome: Newton Compton, 2007); Lisa Corva, Glam cheap (Milan: Sonzogno, 2007).

${ }^{4}$ Elspeth Probyn, 'New Traditionalism and Post-feminism: TV Does the Home', Screen, 31, 2 (1990), 147-59; Probyn, 'Choosing Choice: Images of Sexuality and "Choiceoisie" in Popular Culture', in Negotiating at the Margins, ed. by Sue Fisher and Kathy Davis (New Brunswick: Rutgers University Press, 1993), pp. 278-94.
} 
work flexibility, unemployment and precariato as a threat to personal self-esteem and social affirmation.

\subsection{Professional women between flexibility and precariato}

Recent changes in the workplace, which in Italy have taken place since the mid 1990s, have involved the diversification and multiplication of employment contracts, leading to an expansion of temporary employment. ${ }^{5}$ Law reforms in employment contracts, namely the so-called 'Pacchetto Treu' in 1997 and the much more substantial 'Legge Biagi' in 2003, introduced significant changes that led to a plethora of flexible contracts (collaboratori a progetto, collaboratori a tempo determinato, alongside with lavoratori interinali, occasionali, and autonomi, to name a few) and encouraged the growth of atypical employment characterised by a high discrepancy both in terms of salary and duration. According to available official data, lavoratori precari (flexible employees who do not fall into the traditional system based on full-time, permanent positions) constitute about $13 \%$ of the workforce in Italy, while part-time employees reach $13.5 \%$; in both cases, women are employed in the large majority of those jobs, in particular those in the service, health and education sectors. ${ }^{6}$ Experts in the field of

\footnotetext{
${ }^{5}$ On the labour market in Italy and the related issues of precariato and flexibility, see Annalisa Murgia, Dalla precarietà lavorativa alla precarietà sociale: Biografie in transito tra lavoro e non lavoro (Bologna: Emil, 2010); Virginia Hernanz, and others, 'Dreaming of a Permanent Job: the Transitions of Temporary Workers in Italy and Spain', in Flexibility and Employment Security in Europe: Labour Markets in Transition, ed. by Ruud J.A. Muffels (Cheltenham and Northampton: Edward Elgar, 2008), pp. 79-106; Manuela Samek Ludovici, and Renata Semenza, 'The Italian Case: From Employment Regulation to Welfare Reforms?', Social Policy and Administration, 42, 2 (2008), 160-76; Laura Fantone, 'Precarious Changes: Gender And Generational Politics in Contemporary Italy', Feminst Review, 87, 1 (2007), 5-20. See also The Politics of Unemployment in Europe: Policy Responses and Collective Action, ed. by Marco Giugni (Farnham and Burlington: Ashgate, 2009), and Richard Sennett, The Corrosion of Character: The Personal Consequences of Work in the New Capitalism (New York and London: W.W. Norton, 1999), for a discussion on the various meanings of 'flexibility'.

${ }^{6}$ Samek Ludovici and Semenza, 'The Italian Case', p. 163.
} 
social and economic studies agree in saying that since such changes in the job market have not been backed up by parallel welfare reforms, they 'have reinforced the segmentation of the Italian labour market and social inequalities'. ${ }^{7}$

Indeed, Annalisa Murgia highlights how such a transformation has contributed to creating a general condition of uncertainty and loss of rights among Italian workers, in particular women:

l'articolazione dei tempi e degli spazi tra lavoro e non lavoro, le strategie abitative, la vita quotidiana, così come il tempo libero e gli affetti [sono gli ambiti colpiti] non soltanto dall' imprevedibilità del lavoro (e dalla conseguente discontinuità di reddito), ma anche da una più generale condizione di incertezza, frammentazione e mancanza di diritti. ${ }^{8}$

This reconfiguration of the workplace cannot be fully understood without taking into account the social and cultural backdrop of the posto fisso or lifetime employment (typically in the public sector but also in the private one), a key element of previous generations' identity which since the postwar period has developed into, as Murgia rightly writes, '[la] dimensione pressoché unica e fondante della vita e del sistema di rappresentazione della realtà degli individui' ${ }^{9}$ Guaranteed by statute or collective agreement, lifetime employment meant not only lifetime job security but also lifetime benefits such as paid vacations, sick time and contributions toward a retirement plan. Now deregulated by the new legislation, the posto fisso remains nonetheless a firmly embedded mind-set for Italians: as Murgia notes, while in the last decade the new flexibility has become synonymous with social and economic insecurity among Italy's middle class, the old posto fisso has reached an almost mythical status as the sole

\footnotetext{
${ }^{7}$ Samek Ludovici and Semenza, 'The Italian Case', pp. 169-70.

${ }^{8}$ Murgia, Dalla precarietà lavorativa alla precarietà sociale, p. 125.

${ }^{9}$ Ibid.
} 
provider of stability and certainty: '[il posto fisso è come] una vincita all'enalotto, come il principe azzurro e in ogni caso come ciò che consente di costruire un futuro, ${ }^{10}$ This position, as I shall explain later in this chapter, is indeed voiced by Corva in Glam cheap, where the protagonist is a freelance fashion editor whose life and future are constantly put on hold by her lack of a secure job: 'Ho paura del futuro, di non avere una pensione, di ritrovarmi tra vent'anni allo stesso punto di oggi: disoccupata, con un marito disoccupato'. ${ }^{11}$

In discussing precariato and its controversial impact in contemporary Italy, sociologists have pointed out the fact that 'precarity politics [may] encompass a variety of struggles, including those relating to migration, citizenship, LBGT and feminist movements'. ${ }^{12}$ In this respect, from a 'contemporary Italian post-feminist perspective', Laura Fantone maintains that '[young feminists have] developed a critique not only of precariousness in relation to a flexible job market but also of other less flexible societal structures affecting their lives, such as heterosexual marriage, maternity, care-work and corporate brand loyalty. ${ }^{13}$ Thus in Fantone's view precariousness encourages political and social action, offering Italian feminists the chance to take action against traditional gender roles and assess them critically. In this sense, precariato can be interpreted as a liberating and proactive choice, one that disrupts established societal structures that cripple women's options, and it is in this sense that it finds a place in Canevari and Fiume's novel, as symbolised in the

\footnotetext{
${ }^{10}$ Murgia, Dalla precarietà lavorativa alla precarietà sociale, p. 131.

${ }^{11}$ Corva, Glam cheap, p. 29.

${ }^{12}$ Rosalind Gill, and Andy Pratt, 'In the Social Factory? Immaterial Labour, Precariousness and Cultural Work', Theory, Culture \& Society, 25, 7-8 (2008), 1-30 (p. 10).

${ }^{13}$ Fantone, 'Precarious Changes', p. 8.
} 
following excerpt: '[...] mi piace sentirmi una free-lance a tutti gli effetti, che non ha le ferie pagate, la tredicesima, la quattordicesima e nemmeno la pensione ma che ha la libertà di scegliersi il datore di lavoro, di cambiarne tanti e spesso [...] di lavorare su progetti estremamente diversi tra loro'. ${ }^{14}$ Read against Corva's passage mentioned before, it is clear that the condition of flexible employment appears to be central to both narratives but in dramatically opposite ways: forced on the character and stripped of any guarantee, in Corva's quotation precariato is the source of personal fears and social insecurities, while in the case of Canevari and Fiume it is proudly chosen as a means of freedom and self-affirmation despite the evident shortcomings in terms of welfare.

Canevari and Fiume's excerpt also draws attention to contemporary postfeminist culture, one of the focal aspects of the discussion around chick lit that I have highlighted in Chapter 1. Feminist media critic Rosalind Gill has coined the expression 'postfeminist sensibility' to refer to a media phenomenon that both embraces and challenges feminist and anti-feminist ideologies and that is permeated with neoliberal ideas. ${ }^{15}$ Neoliberal postfeminism is perhaps the most represented ideology in chick lit, where the rhetoric of choice is translated into market-driven consumerism and discourses of individualism and empowerment. ${ }^{16}$ As Angela Mc Robbie maintains, postfeminism encompasses 'the coexistence of neo-conservative values in relation to gender, sexuality and family life $[\ldots]$ with processes of

\footnotetext{
${ }^{14}$ Canevari and Fiume, Voglio un mondo rosa shokking, p. 74.

${ }^{15}$ Rosalind Gill, 'Postfeminist Media Culture: Elements of a Sensibility', European Journal of Cultural Studies, 10, 2 (2007), 147-66 (pp. 148-49).

${ }^{16}$ Amanda Lotz, 'Postfeminist Television Criticism: Rehabilitating Critical Terms and Identifying Postfeminist Attributes', Feminist Media Studies, 1, 1 (2001), 105-21 (pp. 109-10).
} 
liberalisation in regard to choice and diversity in domestic, sexual and kinship relations $; ;^{17}$ as such, neoliberal postfeminism strongly advocates female agency through appealing terms such as 'self-determination' and 'freedom of choice'. Choice is indeed a crucial feminist concept that, in popular postfeminist media, has been rebranded with a new and captivating meaning, summonised in Probyn's notion of 'choiceoisie': on the one hand, the representation of choice in popular media offers women 'a position in an imaginary relation to their material lives'; on the other hand, it has a potentially subversive power that 'can translate into a feeling of possibility' and therefore challenge the status quo. ${ }^{18}$ I should point out that such transformative power attributed to the word 'choice' is confirmed by any thesaurus, where the list of possible synonyms includes variety, abundance, preference, diversity, and - oddly enough - wealth. However, Probyn continues, on the other hand this 'feeling of possibility' is translated into a very limited and conservative outcome, depicting family, children and/or heterosexual love as the natural choice for women. Probyn's notion of 'choiceoise' seems to be at the core of Voglio un mondo rosa shokking, as we shall see in the next part of the chapter.

\subsection{Voglio un mondo rosa shokking (2007): Italian chick lit and popular postfeminism}

In Romantic Comedy, Claire Mortimer examines themes and issues at work in romantic comedy films, using the genre as a lens through which to discuss the changes

\footnotetext{
${ }^{17}$ Angela McRobbie, 'Post-Feminism and Popular Culture', Feminist Media Studies, 4, 3 (2004), 25564 (pp. 255-56). For a cogent analysis of the scholarly literature on postfeminism, see also Sarah Gamble, 'Postfeminism', in The Routledge Companion to Feminism and Postfeminism, ed. by Sarah Gamble (London and New York: Routledge, 2001), pp. 43-53.

${ }^{18}$ Probyn, 'Choosing Choice', pp. 282-83.
} 
in gender politics in the 1990s and 2000s. Mortimer describes the current heroines of cinematic romantic comedies as follows:

[Today's heroines] live on the cusp between strong, empowered choices and more traditional, reactionary fates. They start the film as powerful, successful and free from the confines of the traditional family. They work and play hard, seemingly living the post-feminist dream. Yet at a decisive point in the narrative, their values are overturned and they can no longer find happiness in their former lifestyle. [...] The modern-day heroine learns that she cannot have it all, and can only achieve happiness by sacrificing her urge to compete in the male world and coming to terms with her feminine instinct to be married/coupled and settled. ${ }^{19}$

This quotation may very well be read as the synopsis of Voglio un mondo rosa shokking, a novel that offers the perfect opportunity for a discussion of the representation of professional women in Italian popular fiction in light of popular and neoliberal postfeminism. Co-authored by Rossella Canevari (b. 1977) and Virginia Fiume (b. 1983), the novel started its life as an online book and was later published by Newton Compton's Anagramma in 2007; recent sales figures show more than 40,000 copies sold. ${ }^{20}$ It tells the story of two sisters living in middle-class Milan and dealing with issues related to work, study, love and politics. The younger sister Camilla (written by Fiume) is twenty-three years old and about to graduate; she would like to become a reporter, working on social issues and women's rights. The older Sofia (written by Canevari) is a thirty-years-old freelance TV editor, newly single and focused on her career. From a formal point of view the book is structured in alternate chapters where each character narrates and comments on the events that take place in

${ }^{19}$ Claire Mortimer, Romantic Comedy (New York: Routledge, 2010), p. 30.

${ }^{20}$ Newton Compton, Catalogo 2009 (Rome: Newton Compton, 2009), p. 23. Canevari has published a sequel, Un amore rosa shokking (2008), and has subsequently promoted the expression 'rosa shokking' through various media to endorse initiatives aimed at giving visibility to women in journalism, creative arts and other fields. The experience culminated in the launch of the online magazine 'Mondo Rosa Shokking', of which she is currently the editor in chief: <http://www.mondorosashokking.com/> [accessed 15 June 2010]. 
the story, emphasising the double narrative and giving both sisters equal visibility. Ostensibly marketed by Anagramma as chick lit by means of a cover that boasts a pair of pink stiletto heels against a white backdrop, the novel shares with the genre formal elements such as the single, middle-class protagonists, the urban setting and the exclusively female perspective, the latter emphasised by the two narrators.

As Canevari and Fiume have repeatedly stated in interviews, Sofia and Camilla are semi-autobiographical characters and the novel should be considered as a realistic insight into contemporary Italian women and their various identities across generations. Like many other Italian writers, however, both Canevari and Fiume have explicitly declared that they do not want to be pigeonholed in the chick lit genre. Canevari, for example, has said that she perceives the genre as a cage: 'non mi sento parte della chick-lit e [...] vivo l'essere racchiusa nel genere chick-lit come un limite. Spero che i libri che ho scritto e quelli che scriverò vengano letti e presi per il messaggio che portano, in modo unisex e che possano valicare anche le frontiere italiane'. ${ }^{21}$ What emerges from Canevari's comment is not so much a distancing from the genre based on evaluative or literary criteria; rather, the remark on the 'unisex' features of her writing frames such distancing in gender-specific terms that seem somehow at odds with the exclusively female narrators and focalisers of her fiction. Nevertheless, the 'rosa shokking pensiero' is an awareness that, in the writers' words, stems from valuing and encouraging sexual differences, 'una differenza intrinseca tra uomo e donna che va finalmente coltivata e non nascosta. Tra i due sessi ci sono

${ }^{21}$ David Frati, 'Intervista a Rossella Canevari', Mangialibri (2008) <http://mangialibri.com/?q=node/ 3215> [accessed 10 January 2010] 
differenze biologiche, che portano l'arricchimento di una diversa sensibilità'. ${ }^{22}$

Canevari's words hint at the 'postfeminist sensibility' outlined by Gill, whose central tenets are 'femininity as a bodily property; the shift from objectification to subjectification; [...] a focus on individualism, choice and empowerment; the dominance of a makeover paradigm; and a resurgence of ideas about natural sexual difference, ${ }^{23}$ all of which, as we shall see, find their way into the novel.

Like Canevari, Fiume shows an identical desire to distance herself from the triviality of the chick lit genre, which she links to its themes: "Nei libri "rosa" di solito si parla di shopping e amori, noi abbiamo voluto provare a usare un linguaggio semplice e immediato per parlare di argomenti "seri", ovviamente senza sviscerarli da un punto di vista tecnico, ma come "esperienze di vita" [...] Si tratta di argomenti che da una parte o dall'altra riguardano un po' tutti, uomini e donne'. ${ }^{24}$ That love and shopping are topics devoid of social consciousness remains debatable, but the way Fiume formulates her position makes room for an interesting observation, that is, the switch from 'rosa' as a set of stereotyped narrative tropes to 'rosa' as narrative voice, one that uses a colloquial register and uncomplicated language to describe 'esperienze di vita' that are not so much 'unisex', as Canevari maintains, but rather 'universal'.

In this respect, a noteworthy subplot sees the coming-out of two gay characters, Camilla's friend Daniele and in particular the sisters' cousin Nancy (formerly known as Nunzia). Both subplots offer the chance to advocate gay civil unions and gay

\footnotetext{
${ }^{22}$ Annamaria Sbisà, 'Generazione Rosa Shokking', La Repubblica Milano, 3 July 2007 <http://milano. repubblica.it/dettaglio/Generazione-Rosa-shokking/1334005> [accessed 12 September 2009].

${ }^{23}$ Gill, 'Postfeminist Media Culture: Elements of a Sensibility', p. 149.

24 'Intervista a Virginia Fiume \# 1. Il suo libro, le donne, il lavoro e molto altro', Bizbiz, 19 december $2007<$ http://thebizbiz.blogspot.com/2007/12/intervista-virginia-fiume-1-il-suo.html> [accessed 12 January 2010].
} 
adoption in Italy, a recurrent feature in Italian chick lit, but while it is typically presented from the perspective of gay male characters, Voglio un mondo rosa shokking is, to my knowledge, unique in choosing to give significant narrative space to a lesbian couple, in line with the novel's interest in representing contemporary women's various identities. After having moved to Canada in order to escape from the patriarchal restrictions of her small village in Southern Italy, Nancy returns to Italy for the first time in years to celebrate Camilla's graduation, but when she shows up with girlfriend Kylie the family struggles to accept her sexual orientation. Although a discussion of lesbians and their representation in women's popular fiction goes beyond the purpose of this chapter, Nancy and Kylie fall within postfeminist discourses of empowerment and choice that deserve further attention. The two characters are consistent with representations of homosexuality borrowed from mainstream Anglo-American popular fiction, depicted as they are as conventionally attractive women in a solid relationship, thus their place in the narrative conforms to that of a 'normalised-heterosexualised' couple. ${ }^{25}$ Moreover, their glamorous appearance and successful life prove to be instrumental for the couple's assimilation into the family. For example, when Sofia's father learns the news, he is very disappointed and, in a clichéd dialogue that plays on stereotypical images of lesbian characters in popular culture, he rudely asks whether Kylie is 'del genere camionista o figa'; when he eventually meets her, he is struck by her beauty: 'Credo di averlo visto poche volte così imbambolato di fronte a una bella

\footnotetext{
${ }^{25}$ Ann M. Ciasullo, 'Making Her (In)Visible: Cultural Representations of Lesbianism and the Lesbian Body', Feminist Studies, 27, 3 (2001), 577-608 (p. 578). Ciasullo's essay offers a reading of the portrayal of the lesbian body in 1990s mainstream cultural landscape that is still very relevant to the representation of lesbianism today.
} 
donna' ${ }^{26}$ By contrast, Nancy’s father Mimmo, who embodies Southern-Italian conservative values, upon discovering his daughter's lesbian relationship starts a violent row during a traditional family lunch, only to be portrayed in the finale as the proud (but still in denial) father of a successful career woman: 'Zio Mimmo [...] anche se finge di non capire la natura del suo rapporto con Kylie è molto orgoglioso [della] figlia'. ${ }^{27}$ Both passages are exemplary of how, despite the prominent role, the lesbian couple is assessed against specific socioeconomic attributes and, as Ciasullo rightly argues, 'channelled through commodification and consumerism' ${ }^{28}$ that safely constrain their potentially disruptive role in the narrative.

Although intended as a mirror of contemporary women's multiple identities, the novel gives Sofia's storyline considerably more space, while the younger Camilla keeps to the less problematic coming-of-age story and casts an eye on contemporary youth culture in Milan, from university to nightlife. Camilla's chapters, written by Fiume, are imbued with a fresh tone that makes the most of the first person narrator, delivering a naïve but rather believable picture of youth jargon and culture in Milan. From the very beginning Camilla comes across as a tomboyish twentysomething with little to no interest in fashion and consumer culture: 'un giorno o l'altro imparerò a vestirmi e truccarmi, ma non è colpa mia se non ne ho voglia'. ${ }^{29}$ Instead, she is actively involved in grassroots movements and finds herself at ease in alternative spaces such as the Leoncavallo, Milan's iconic social, political and cultural centre: ‘[c]orrisponde esattamente alla mia idea di centro sociale, anche se ormai è di fatto un monumento a se

\footnotetext{
${ }^{26}$ Canevari and Fiume, Voglio un mondo rosa shokking, p. 183.

${ }^{27}$ Canevari and Fiume, Voglio un mondo rosa shokking, p. 223.

${ }^{28}$ Ciasullo, 'Making Her (In)Visible', p. 605.

${ }^{29}$ Canevari and Fiume, Voglio un mondo rosa shokking, p. 30.
} 
stesso. Un monumento della nostalgia di un passato di contestazioni e battaglie che ormai riguardano altri centri sociali più agguerriti' ${ }^{30}$ Surprisingly, while throughout the novel Camilla voices feminist principles about women's issues and rights, she outrightly rejects the label of femminista, which she perceives as ideologically overcharged; in this respect, she embodies the paradigmatic 'I'm not a feminist but...' that is so frequently seen in postfeminist popular culture in order to 'incorporate, assume, or naturalize aspects of feminism, ${ }^{31}$ Camilla gains real autonomy only toward the end of the novel, when after graduating she chooses to leave Italy and moves to Canada in search of better prospects. Here she starts volunteering with various youth associations and eventually finds a love interest, a mature social worker who cares for youth at risk. Camilla's final chapter chronicles her settling in the new environment and shows a genuine character development that, had it been introduced earlier, would have added more texture and depth not only to her storyline but to the novel in general. Instead, the novel's main focus remains steadily on Sofia's plot and the issues she confronts.

\subsection{A 'shokking' choice: the ambiguous realism of Voglio un mondo rosa shokking}

As mentioned above, Sofia's storyline is the focal point for a discussion of job accessibility and career options for women, providing a commentary on the anxieties, assumptions and desires related to these themes. At the beginning of the novel, Sofia introduces herself and declares her values:

\footnotetext{
${ }^{30}$ Canevari and Fiume, Voglio un mondo rosa shokking, p. 120. A good analysis of Leoncavallo's history is available in Andrea Membretti, 'Centro Sociale Leoncavallo', European Urban and Regional Studies, 14 (2007), 252-63.

${ }^{31}$ Yvonne Tasker and Diane Negra, eds, Interrogating Postfeminism: Gender and the Politics of Popular Culture (Durham: Duke University Press, 2007), p. 2.
} 
Ho trent'anni, da tre lavoro come autrice televisiva, ruolo che amo e che non cambierei per nulla la mondo. [...] Sono una di quelle persone che vive del proprio talento, che ama dare il massimo e che non ha bisogno della rete di sicurezza per volare nel vuoto. Mi piace provare il brivido del rischio, confrontarmi con gli imprevisti e vivere alla giornata. [...] Ho il potere di farlo io, che sono una donna nata ed educata in un paese libero e democratico, una donna che ha avuto in sorte una famiglia unita e benestante. Una donna fortunata. ${ }^{32}$

By presenting herself as an assertive woman who is at ease in contemporary society and happy to embrace work flexibility as an expression of agency and selfdetermination, Sofia shows traits that are typical of neoliberal postfeminist culture, including the awareness of her white, middle-class and educated privilege in regard to the unlimited choices she has when it comes to work and lifestyle. Alongside such passionate approach to her profession in the media, throughout the novel Sofia addresses the appalling state of Italian television and the overwhelming objectification of the female body it bolsters, voicing her dislike as follows: 'Non basta la testa in Tv, anzi se sei una donna la testa porta solo sofferenza. Meglio avere un bel paio di tette, un culo di marmo, occhi da cerbiatta e un vuoto cosmico sotto un mare di capelli, ${ }^{33}$ Here Sofia is commenting bitterly on to the so-called veline, the attractive and almost unclothed showgirls that in the last two decades or so have become the symbol of Italian television's overt sexism. ${ }^{34}$

In this context, her unwanted pregnancy is introduced into the narrative as the disruptive element that shakes Sofia's confidence, forcing her to make a decision:

\footnotetext{
${ }^{32}$ Canevari and Fiume, Voglio un mondo rosa shokking, pp. 74-75.

${ }^{33}$ Canevari and Fiume, Voglio un mondo rosa shokking, p. 55.

34 There is no room here to dedicate to the topic the thorough investigation it would deserve. For an exhaustive overview of the role and the representation of women in Italian media see Giovanna Campani, Veline, nyokke e cilici: femministe pentite senza sex e senza city (Bologna: Odoya, 2009); Norma Rangeri, Chi l'ha vista? Tutto il peggio della TV da Berlusconi a Prodi (o viceversa) (Milan: Rizzoli, 2007); and in particular Lorella Zanardo's documentary Il corpo delle donne <http://www.ilcorpodelledonne.net/> [accessed 14 January 2011].
} 
become a single mother or pursue her career? As I shall demonstrate, Probyn's rhetoric of 'choiceoisie' is fully displayed here: initially Sofia thinks she should concentrate on her career, mostly because she has just been promoted and is about to produce her first TV program, a reality show 'on the road' set in the United States that would involve her relocation to New York City. Forced by her male boss to make a choice, Sofia believes that abortion is the only feasible option:

A questo punto la questione gravidanza è definitivamente chiusa. [...] Questa esperienza è quello che ho sempre aspettato: il mio sogno è da sempre di vivere a New York e questo è quello che mi serviva per arrivarci. Lo so, sto per uccidere questa piccola creatura, ma non sarebbe peggio metterla al mondo con dei rimpianti? [...] Forse pagherò questa scelta tutta la vita, ma sono pronta ad assumermi le mie responsabilità. ${ }^{35}$

The passage introduces the career vs. mothering dilemma, a key topic in women's politics and one that echoes the difficulty experienced by many professionals to balance motherhood and work career. On the one hand, we are faced with Sofia's assertiveness and her willingness to hold onto the long-awaited career jump and the prospects of living permanently in New York, stylistically rendered through the adverb definitivamente and the repetition of sempre ('quello che ho sempre aspettato'; 'il mio sogno è da sempre'); on the other hand, doubt and hesitation are also voiced, signalled by emotionally and ideologically charged phrases such as 'sto per uccidere questa piccola creatura' and 'forse pagherò questa scelta per tutta la vita' that anticipate what will indeed happen a few pages later, when a conversation with her grandmother will point Sofia toward the right choice:

'Sofi, tesoro, sei una donna... Non rinnegarlo mai, anzi, fai in modo che quello che pensi sia la tua debolezza diventi la tua forza... Cammina con la

${ }^{35}$ Canevari and Fiume, Voglio un mondo rosa shokking, p. 176. 
testa alta, luminosa, e accetta il tuo destino...' Sento le parole [della nonna] penetrarmi in profondità. So che ormai mi hanno già cambiata. ${ }^{36}$

The above passage, which closes the grandmother's two-page speech, poses a number of problematic questions, not only from a textual point of view but also - and most importantly - from an ideological one. I acknowledge that Canevari wanted to give voice to the complex web of social, economical and cultural discourses in which a single woman expecting a baby and working full-time finds herself caught up, but if the narrative turning point was meant to be the decision to continue her pregnancy, as was the case of Federica Bosco's L'amore mi perseguita, then framing it as a matter of 'destiny' denies its complexity and, ultimately, the whole notion of choice. I shall elaborate on this shortly; for now, I would like to highlight how Canevari links Sofia's decision not to the character's own reflections or to those of a close friend (like Bosco did) but to her grandmother, making its moral implications even stronger. The elderly figure is presented as the personification of an ancient wisdom that is morally 'true', and later in the novel Sofia will indeed comment upon the effect that those words have had on her: 'È stato un attimo, l'attimo in cui grazie a nonna Rosa ho percepito la vita e il potere che avevo. Il potere che ha ogni donna di dare o negare la vita' ${ }^{37}$ It might be said that Sofia eventually chooses motherhood out of a range of multiple options, suggesting a sense of control and empowerment (indeed she stresses the word 'il potere', repeated twice in the same sentence), but I would argue that because such a choice is presented as a celebration of her reproductive destiny ('accetta il tuo destino'), it comes across as purely reflexive. It is worth noting that, prior to meeting

\footnotetext{
${ }^{36}$ Canevari and Fiume, Voglio un mondo rosa shokking, pp. 196-97.

${ }^{37}$ Canevari and Fiume, Voglio un mondo rosa shokking, p. 212.
} 
her grandmother, Sofia was going to terminate the pregnancy but then again, as Probyn reminds us, at the core of the ideology of 'choiceoisie' there is an acknowledgement of 'what has supposedly been there, always ready there for the right women'. ${ }^{38}$ In other words, Sofia does not really make a choice; rather, she simply follows her natural biological path as a woman.

A second reflection raised by the text is that the feminine instinct to be married/settled noted by Mortimer in Anglo-American romantic comedies is replaced in Canevari's novel by the rhetoric of motherhood, a trope that in Italian popular fiction dates back to Carolina Invernizio, the precursor of Italian popular romance. As previously discussed, the most innovative element in Invernizio's fiction was the role accorded to women as 'agente risolutore', that is to say, the driving force of the story. ${ }^{39}$ Yet, as critic Eugenia Roccella has noted, the centrality of women is expressed through a very limited perspective, the one afforded them by the 'onnipotenza materna' ${ }^{40}$ In Invernizio's novels, motherhood is the sole power a woman has, one that enables her to overcome desperate situations, and as such she is exclusively defined by it. More than a century later, the idea that a woman's power comes from being first and foremost a (potential) mother resurfaces in Sofia's words: '[ho scoperto il] potere che ha ogni donna di dare o negare la vita'.

Single, pregnant and unemployed (the latter as a consequence of her decision to carry on with the pregnancy), Sofia sees her newly-embraced motherhood and her precarious status not as a setback but as a resource. Realising that childcare is the

\footnotetext{
${ }^{38}$ Probyn, 'New Traditionalism and Post-feminism', p. 152.

${ }^{39}$ Umberto Eco, 'Tre donne intorno al cor...', in Umberto Eco, and others, Invernizio, Serao, Liala (Florence: La Nuova Italia, 1979), pp. 3-27 (pp. 22-23).

${ }^{40}$ Eugenia Roccella, La letteratura rosa (Rome: Editori Riuniti, 1998), p. 19.
} 
biggest hurdle for professional women, she resorts to her entrepreneurial skills and opens a private nursery school for free-lance women ('Nido Rosa Shokking, il nido per donne free-lance'). By the end of the novel, Sofia is a successful single mother and entrepreneur who recounts her achievement as follows:

All'inizio l'idea mi fece ridere. Io, Sofia, con le mie velleità alla Sex and the City, proprietaria di un nido. Assurdo. [...] Una vera sfida. La strada che nessuno avrebbe mai immaginato che io potessi prendere. [...] Volevo essere indipendente, creare qualcosa con le mie forze, senza dover chiedere aiuto o dover rendere conto delle mie azioni a nessuno [...] M'immaginai in un loft tappezzato da personaggi dei manga e del mondo Disney, con la mia piccola che giocava felice con altri bambini. [...] Quell'immagine mi piacque, assomigliava molto a un sogno. ${ }^{41}$

Sofia's reflections offer us the opportunity to reconsider neoliberal postfeminist discourses of empowerment and individual assertiveness in women's popular fiction, and how these notions are articulated in relation to work flexibility and motherhood. Sofia's fantasy of a life modelled on American TV show Sex and the City, as we have seen a recurrent trope in Italian chick lit, is reshaped against more traditional values that are, however, still challenging ('una vera sfida') but seductive nonetheless ('Quell'immagine mi piacque, assomigliava molto a un sogno'). In this sense, Sofia's 'sogno' gains a higher meaning in the text, even more so because it is textually juxtaposed to her former 'velleità': far from referring to something unattainable and capricious, like being successful in the media industry, it stands for a vision that would change the character's life forever. Indeed, in the above passage Sofia stresses the urge to be independent and the centrality of freedom in the workplace as the main force behind her decision. In light of the scholarly literature on work flexibility in Italy, it

${ }^{41}$ Canevari and Fiume, Voglio un mondo rosa shokking, p. 220. 
seems to me that Sofia's optimistic finale (and rightly so in the spirit of the genre) is however too stark a contrast with the reality of a vast majority of middle-class lavoratrici precarie who do not consider flexibility as an expression of freedom or creativity, but rather claim to have to put on hold motherhood because of the lack of a secure job (and therefore of a stable income) and social infrastructures. Even when they do have babies, they lament the instability of their lives and the enormous sacrifices they must make to balance work and family, regarding the posto fisso as the jackpot that would solve their problems. ${ }^{42}$

In this respect, I must point out that it is only thanks to a change of fortune that Sofia is indeed able to achieve her dream of independence and creative flexibility. After the death of her grandmother, the same one who had encouraged her to have the baby, Sofia inherits enough money to invest in the nursery and, with financial help from her sister Camilla and cousin Nancy, she is finally ready to start her own business. Sofia's last words seal the happy ending:

[...] il Rosa Shokking [ha avuto molto successo]. Aumentare il volume di lavoro potrebbe essere redditizio, ma abbiamo paura di perdere la dimensione familiare che si è creata in questa piccola struttura femminile, così intima e creativa. [O]ggi intravedo nel lavoro che faccio, anzi nel 'business' che abbiamo creato, qualcosa di molto più interessante del piccolo mondo antico della Tv. Sono madre, felice. ${ }^{43}$

Sofia's final statement invites us to see her achievement as resulting from a double course of action: on the one hand, her identity and self-determination as woman are empowered by her choice of becoming a mother; on the other hand, we see a group of women taking action on the grounds of common interests and needs. The career vs.

\footnotetext{
${ }^{42}$ Murgia, Dalla precarietà lavorativa alla precarietà sociale, pp. 76-77, pp. $89-90$ and p. 130, respectively.

${ }^{43}$ Canevari e Fiume, Voglio un mondo rosa shokking, p. 227.
} 
mothering dilemma is thus solved thanks to a business that provides Sofia and her clients with the unique combination of a safe job, solid income and an intimate and creative outlet for them as mothers. From this perspective, I find interesting the fact that the word business is put between quotation marks, calling for an ambivalent interpretation from the audience's point of view: while it could signal an unwillingness to associate childcare with commerce and marketing strategies, it also invites a subversive reading of the term that is specifically feminine (made by women, for women, and therefore caring and nurturing). Either way, the peculiarity of the 'business' is indeed reinforced when Sofia - now a fully-fledged entrepreneur - is presented as willing to limit profit in order to preserve the quiet, domestic atmosphere that constitutes the nursery's distinctive trait. Similarly, the inclusion of Nancy - who at some point in the story had voiced her regrets for not having biological children (as a consequence of being a lesbian) - vicariously gives her access to motherhood, which is in turn reinstated as the defining attribute for every woman.

In this context, the novel's finale reintroduces the sentimental plot. Narrated by Camilla in the third person, the epilogue informs us that, through the nursery, Sofia has met a new love interest, a single father with a newborn child: 'Sono sei mesi che Sebastian e Sofia si frequentano. Non hanno mai parlato del futuro, ma non c'è niente di meglio che godersi il presente [...] In fondo entrambi hanno già sperimentato l'amore più grande possibile, che tengono fra le braccia'. ${ }^{44}$ The tropes of romantic love and long-term commitment are reinstated in the text only to be overruled by parental love, a narrative 'choice' that seals motherhood as the core of Sofia's achievements.

${ }^{44}$ Canevari and Fiume, Voglio un mondo rosa shokking, p. 248. 
As we have seen, the novel's ambition to provide a poignant picture of Italian women in the workplace and the issues they face rests on a combination of postfeminist discourses and social politics, yet it struggles to make sense of them cohesively. Vivien Jones, for example, makes this concern explicit when she argues that chick lit 'represents feminist gains in the coercive form of good jobs, sexual freedom and - importantly - the right to be funny. But the "personal choices" it really cares about, its love plots and style statements [...] define it as essentially conservative'. ${ }^{45}$ Sofia's feminist cry for equal treatment in the workplace not only remains unheard, but moves to the background as soon as she becomes a mother; indeed, her final words equate motherhood with total happiness: 'Sono madre, felice'. Likewise, the choice of career over motherhood, one of the most debated topics in feminist politics, is easily overturned in the name of biological destiny, rendering preposterous all intentions of realistic representation. As I show in the next part of the chapter, this is not the case with Corva's Glam cheap, a novel that despite its cheerful tone is more successful in calling attention to the consequences of work flexibility for women.

\subsection{Love on a shoestring: unemployment and flexibility in Glam cheap (2007)}

Written in 2007 by Lisa Corva (b. 1964), a fashion journalist and contributor to the Italian women's monthly Grazia, Glam cheap tells the story of a middle-aged couple encountering precariato, unemployment, economic hardship and consumerism. The protagonist Stella is a freelance fashion editor juggling several contracts, while her

${ }^{45}$ Vivien Jones, 'Post-feminist Austen', Critical Quarterly, 52 (2010), 65-82 (p. 73). 
fortysomething husband is a top manager for a corporate firm in Milan. Their affluent lifestyle quickly falls apart when the husband is made redundant and cannot find a new job; the couple quickly moves from a pampered life into one with serious financial constraints, where Stella's lavoro precario becomes their only income. At the same time, their marriage struggles to cope with the financial meltdown, as the downscaling of their lifestyle gradually leads to a loss of self-esteem and identity.

The novel is interesting for a number of reasons, mainly because it uses chick lit staples such as glamorous parties, designer clothes (particularly shoes, as we shall see), and consumer culture to comment on the ephemeral yet alluring worlds of media and fashion, well captured in Corva's prose thanks to her in-depth familiarity with these environments. In doing so, Corva takes advantage of the genre's distinctive humorous register to highlight the collision between the demands of consumer culture in contemporary Italy and the uncertainty in which many people live nowadays. In this respect, the novel also deals with the relics of the notorious 'Milano da bere ${ }^{46}$ and comments on how people define themselves according to what they can afford, socially and financially. Indeed, as implied in the subtitle of the novel (which reads 'Amore, moda e disoccupazione'), one of its main themes is Stella's education in budgeting, as she is forced to switch from credit cards, exclusive stores and restaurant dinners to fidelity cards, discount stores and home-cooked meals. Quite predictably, this process forces Stella to assess negatively the unapologetic consumer culture she had previously embraced. However, Corva stays away from patronising tones and

\footnotetext{
${ }^{46}$ Taken from a successful advertising campaign created in the 1980 s, the expression 'Milano da bere' (whose meaning is something along the lines of 'Milan is as cool as a good drink') today holds negative connotations and describes the city's political and economical corruption, as well as the culture of excessive spending and consumerism during those years.
} 
focuses instead on the constructed nature and purpose of consumer culture, pointing out the expectations, as well as the anxieties, that it generates in contemporary society. Corva's original strategy is exemplified by the following passage:

Tutti, o quasi, stringono un sacchetto di carta o plastica dall'aria sciccosa. Guardo meglio. Ma come, quello è il sacchetto bianco e lussuoso di Prada, con il logo bene in vista; quell'altro marrone scuro è di Gucci, quello di D\&G... E allora perché tutti ne estraggono non l'ultimo acquisto [ma] una felpa, un pacchetto di fazzoletti di carta, una mela.

[...] Poi capisco.

Sono i Nuovi Poveri come me, la Generazione Eurostress, che per sognare almeno un po' usa come borsa un sacchetto griffato.

[...] Come, non vedete? Non sono un'impiegata, e neppure una badante, e neanche la schiava di un call center. Macché. ${ }^{47}$

The passage depicts a bizarre image of people who disguise their modest items in shopping bags that boast designer monograms, in the attempt to define themselves not as humble secretaries, caregivers or call-centre operators, but as different and certainly better individuals who shop in designer stores and who just happen to work as secretaries, caregivers and call-centre operators (jobs that, I should point out, are currently the epitome of flexible employment in Italy). Whether ironic or not, this game of smoke and mirrors is at the core of Corva's narrative and is echoed for example in Stella's job, which requires the ability to recognise what celebrities wear, name the price tag to each item and offer a cheaper alternative for the magazine's readers, who presumably cannot afford designer clothes but want to appear trendy and fashionable nonetheless.

Similarly, Corva takes advantage of the mode of address typical of the genre (the first person narrator and the ironic tone) to openly address the audience and engage

${ }^{47}$ Corva, Glam cheap, pp. 153-54. 
them in a constant dialogue with the protagonist. In this respect, Corva makes the most out of the chick lit narrative voice and attitude, which she manages with great confidence to shape lively characters and situations. This becomes clear when she describes her job to the readers:

Faccio la giornalista finto glam. Traduzione: la colf dell'editoria. [...] Voi state già pensando a un lavoro molto glamour, magari con una capa cattiva che ti soffia sul collo ma con un sacco di scarpe e borse gratis [...]. Sbagliato. Vedo che, come me, avete visto troppi film targati Hollywood. Qui siamo in Italia [e le giornaliste] per sopravvivere devono rassegnarsi a lavorare 'a ore'. Sì, proprio come le colf. [...] La capa cattiva? Magari. Io ne ho una sfilza, tutte diverse: e nessuna che si decida ad assumermi. ${ }^{48}$

Disguised as playful dialogue between narrator and audience, the passage offers multiple levels of reading. When Stella recalls the many Hollywood comedies about glamorous fashion journalists and daunting bosses, she is obviously making an intertextual reference to the screen adaptation of chick lit bestseller The Devil Wears Prada (and perhaps also to iconic columnist Carrie Bradshaw of Sex and the City). At the same time, by describing her actual job as 'giornalista finto glam' and 'colf dell'editoria', Stella is not only commenting on the representation of the media industry in chick lit and its reception in Italian popular culture, but also highlighting the split between fiction and reality, characterised by the ongoing imbalance of her position in terms of both financial and professional satisfaction. The latter becomes soon evident:

Perché molte precarie chic (quelle più fortunate di me) sono in possesso del mitico contratto a termine, o a progetto, o di collaborazione; insomma un pezzo di carta con una data stampigliata sopra. Poi ci sono le stagiste, più sfortunate perché lavorano tanto quanto e non vengono neppure pagate. Anche loro con la data di scadenza, come lo yogurt. "E tu quando scadi? E tu, quando scadi?",49

\footnotetext{
${ }^{48}$ Corva, Glam cheap, p. 15.

${ }^{49}$ Corva, Glam cheap, p. 163.
} 
The supposedly glamorous life of a freelance fashion journalist is in fact an anxious rat-race through a maze of temporary contracts and against other freelancers and interns, each one of them equally desperate to get the 'mitico' fixed-term contract before their expiry date. The scene, ironic and depressing at the same time, underscores not only the diffuse sense of insecurity among professional women, but also the fleeting value of their skills in the workplace, just about to reach their use-by date like a yogurt.

Another significant stylistic feature to consider is Corva's use of catchwords such as 'Marito Licenziato', 'Matrimonio in Bancarotta', 'Assunte Miracolate' and so on to label people and situations throughout the novel. Their repeated use and particularly their capitalisation support the ironic emphasis to their role and meaning in the narrative. At the same time, this device suggests that everything and anything can be labelled, from people to professions to private crises. In an extended metonymy, where a thing or name works as a symbol of something else, Corva's style allows readers to infer that these labels, like fashion brands, become what intimately defines the bearers in Stella's eye. This is particularly true in the case of 'Assunte Miracolate', the professional precarie who seem to be miraculously healed by a full-time permanent contract: the mythical status of the old posto fisso outlined by Murgia early in this chapter, as well as its extraordinary powers when it comes to social welfare, could not be better captured. In the next part I will examine Corva's repositioning of gender roles in the marketplace, and by extension within the couple, by looking more in detail at the relationship between Stella and her 'Marito Licenziato'. 


\subsection{Mogli Mantenute, Mariti Licenziati e Uomini Extralarge: negotiating female and male identities in the marketplace}

Throughout the novel, Corva chooses to convey the sense of uncertainty that overwhelms 'flexible' individuals (that is, those who are constantly in and out of work) by giving more narrative space to Stella's husband, whose thoughts are voiced in separated chapters within the story, a narrative strategy that in many ways is similar to the double narrative of Voglio un mondo rosa shokking. In a stylistic shift worth noting, however, Corva renders the male voice by means of short, italicised monologues that are weighted with considerably heavier tones, addressing the different (and gendered) ways in which the novel's protagonists elaborate and respond to their changing reality. While initially the couple somewhat welcomes the sense of freedom that comes with being between jobs and enjoys little pleasures such as sleeping in and spending more time together, for Stella's husband the unexpected transition into permanent unemployment is socially and emotionally shattering. The centrality of this issue is posed halfway through the novel, when he accidentally meets another jobless man and suddenly awakens to his condition: ' $\mathrm{Ci}$ siamo riconosciuti senza dir nulla. Io ho abbassato gli occhi, lui ha balbettato qualcosa. Due uomini senza lavoro. Senza reddito. Senza identità. [Oggi c]hi non produce è perduto'. ${ }^{50}$ Being 'unproductive' seems to cast on men a very perceptible aura, a disgraceful one that relegates them to the lowest end of the social spectrum. The alienation experienced by the male character and his progressive loss of identity are counteracted by Stella's resourcefulness: just like Sofia in Voglio un mondo rosa shokking, she is portrayed as a

\footnotetext{
${ }^{50}$ Corva, Glam cheap, p. 170.
} 
brilliant and confident woman who constantly looks for new opportunities to get some cash, such as converting their apartment into a temporary B\&B and taking part in a local flea market to sell all of her designer shoes. Yet, Glam cheap departs from Voglio un mondo rosa shokking insofar as it does not appear to celebrate neoliberal politics as a means of agency and empowerment, particularly for women, but rather it reads such politics as a threat to social and personal self-confidence and affirmation. ${ }^{51}$

In light of what I have discussed so far, Stella acting as the breadwinner is worth analysing in depth. In particular, the repositioning of gender roles and responsibilities within the couple and in the marketplace makes room for discourses of identity construction in relation to dominant social and cultural models in contemporary Italy. Compare for example the following passages, in which each character reflects on their daily activities:

Mi sentivo un infiltrato, un fuori posto. In centro alle 11 del mattino. Per anni e anni sono uscito presto, prestissimo, con giacca e cravatta; e sono tornato la sera tardi. Non avevo idea che in giro, nelle ore in cui io ero occupato a firmare, ordinare, litigare e produrre, ci fosse [altra] gente. ${ }^{52}$

[...] io vado al lavoro, lui torna a casa. Perché un Marito Licenziato non esce più di casa per andare in ufficio, per affrontare il mondo e tornare con uno stipendio. Sono io quella che esce, che sgomita per un posto in autobus, che sopporta capi e colleghe, che torna a casa stravolta e arrabbiata. [...] Quando infilo le chiavi nella serratura, lui è lì, dove lo avevo lasciato al mattino. [...] C'è qualcosa di innaturale in tutto questo. Non dovrei essere io a rimanere a casa ? $^{53}$

In the first excerpt, a walk in the CBD during office hours becomes for Stella's

\footnotetext{
${ }^{51}$ Similarly, Corva's first novel dealt with the theme of infertility and assisted reproductive technologies. The book was published in 2005, when the focus of the political debate in Italy was a bleak and restrictive legislation on reproductive rights that, among other things, denies access to assisted reproduction to single women and same-sex partners (Legge 40/2004). Corva has actively voiced the need for a change in the legislation.

${ }_{53}$ Corva, Glam cheap, p. 136.

${ }^{53}$ Corva, Glam cheap, pp. 13-14.
} 
husband more and more painful, as the formerly workaholic top manager finds himself estranged, 'un fuori posto' with way too much time on his hands; the same sense of estrangement is reinforced in the second passage, where Stella defines 'unnatural' a situation where she has work responsibilities and her husband stays at home. In Stella's view, the role of the housewife is never considered attractive in itself; rather, it is the rhetoric surrounding it that makes both characters question, reluctantly perhaps, the displacement of the traditional framework. Here I turn to The Task of Cultural Critique, where feminist cultural theorist Teresa Ebert reflects among other things on popular culture in contemporary society and focuses on popular genres like romance novels and chick lit. Against a widely held position that considers such products disconnected from reality, Ebert sees them as 'one of the main practices through which contemporary reality is constructed, understood, and experienced'. ${ }^{54}$ More precisely, Ebert reads chick lit as 'the romance of postcontemporary cynical reason', in so far as it presents narratives that are 'cynical about the whole idea of love as fulfilment' and where male figures are 'ironically rewritten, disrupted, and dispersed' ${ }^{55}$ As mentioned before, Stella refers to her husband as 'Marito Licenziato' or 'Slicenziato' to mock his professional status, yet behind the playful comment looms an increasing irritation toward him and she frequently mulls over his emotional withdrawal, which given the circumstances she considers gender-inappropriate, so to speak.

The dissatisfaction in her 'dispersed' husband leads to the desire of leaving him for a wealthy man who is stylishly courting her. As Ebert convincingly observes, the 'fantasy of a propertied male who can take care of the heroine is an imaginary pleasure

${ }^{54}$ Teresa L. Ebert, The Task of Cultural Critique (Urbana: University of Illinois Press, 2009), p. 98. ${ }^{55}$ Ebert, The Task of Cultural Critique, pp. 104-05. 
that speaks to many a reader's real economic situation [...] Chick lit both desires and ironically disrupts the fantasy of love, property and fulfilment that romance promises ${ }^{56}$ Indeed Stella fantasises about the newly met 'Uomo Extralarge', a man 'che non paga con la Visa, che tira fuori una banconota dopo l'altra senza chiedersi quante ce ne sono ancora' ${ }^{57}$ Stella is less impressed by the men's wealth and prestige than by the mesmerising physicality of money, because it is the visual account of the banknotes spilling out of a wallet (as opposed to the abstraction of a credit card) that immediately tells her the potential lover's worth: ‘vedo fruscianti biglietti, così rassicuranti...'. Not surprisingly, Stella laconically admits that her marriage is about to trip over the bank statement, yet a few chapters later Corva disrupts Stella's fantasies by transforming the gallant and wealthy gentleman, 'il corteggiatore con il portafoglio ben fornito, ${ }^{58}$ into a shoe fetishist interested only in her expensive René Caovilla shoes. Stella's discovery is amusingly recounted in a way that is reminiscent of Bluebeard's fairytale: invited for dinner to his lavish villa, she fantasises about her future position as a wealthy housewife, but the hope of being finally safe from financial woes vanishes when she mistakenly opens a door and is faced with a master bedroom full of designer shoes, remnants of former lovers. Horrified, Stella runs away, saving both herself and her shoes. Comic in purpose, the episode is significant to the extent that it exploits the fantasy of a male provider typical of romance fiction while simultaneously subverting the figure of the male provider himself: in the first case, Stella refers to her potential new persona as 'Moglie Mantenuta', a derogative term for

\footnotetext{
${ }^{56}$ Ebert, The Task of Cultural Critique, pp. 111-13.

${ }^{57}$ Corva, Glam cheap, p. 134.

${ }^{58}$ Corva, Glam cheap, p. 198.
} 
an upper-class trophy wife that underlines her submissiveness and evokes more capitulation than fulfilment; in the second case, the reversal of a major chick lit trope (that is, the obsession with designer shoes) re-positions the male figure not only against discourses of commodified love, but also within the consumer culture that chick lit typically associates with women. It is true that both Stella and Uomo Extralarge obsess over a pair of Caovillas, but while the man objectifies the designer shoes by considering them a trophy to add to his collection, Stella's attachment to them is of a different kind and stresses their emotional value: earlier in the narrative she had refused to sell them at the flea market despite the financial meltdown, not for narcissistic reasons but because they were the shoes she was wearing on her very first date with her future husband. Thus, in the novel the shoes move between opposite yet intertwined poles: on the one hand they symbolise the entanglement in consumer culture that affects people regardless of their gender and affluence; on the other hand, in the episode described above they become the means by which Stella wins back some sense of identity.

Later in the novel, consumer culture and the obsession with fashion brands are once again under scrutiny, notably when on the spur of the moment Stella steals one of the many designer bags that her boss keeps in the closet. While the attachment to the Caovillas is linked to a key episode in Stella's life and reconnects her to her past, the need to own a limited-edition designer bag exposes the role of commodity brand names in the construction of women's social identities: ${ }^{59}$

\footnotetext{
${ }^{59}$ On this topic, an insightful perspective can be found in Aaron C. Ahuvia, 'Beyond Extended Self: Loved Objects and Consumers' Identity Narratives', Journal of Consumer Research, 32 (2005), 171-84.
} 
[A]ccarezzo [la borsa] amorosamente, ammiro i dettagli, le cuciture, la bacerei quasi. La indosso con noncuranza e mi specchio nelle vetrine. Devo dire che si abbina bene con la mia frangetta. Devo dire che me la merito proprio. Certo, con una borsa limited edition come questa mi sento anch'io un'edizione a tiratura limitata. Una donna unica. Un prototipo. ${ }^{60}$

When Stella feels the urge to caress the bag tenderly, to kiss it even, she displays the same kind of affection that she would show a lover. Likewise, the possession of a limited-edition bag - a privilege accorded to celebrities only - vicariously strengthens her sense of self-worth within society. As Stella uses the bag to construct and reframe her identity, she states that she deserves to have a bag like that, because it brings out what would otherwise remain invisible, that is, the fact that she is a sophisticated woman who embodies beauty and exclusiveness at once: 'mi sento anch'io un'edizione a tiratura limitata'.

Shortly afterward however, Stella's musings quickly turn into calculations when she realises that she could make good money out of the bag and tries to sell it to a pawnshop, only to discover that it is a forgery. After the initial shock, Stella opts for a surprisingly sympathetic approach: 'Ho un moto di compassione. Povera borsa. La accarezzo con rinnovata tenerezza. Siamo un po' finte tutte e due, tutte e due non valiamo molto sul mercato'. ${ }^{61}$ Upon discovering the phony nature of the bag, the physical excitement that Stella had previously experienced in caressing and touching it morphs into a softness that has more to do with compassion than rapture, downplaying the previous erotic subtext that linked Stella to the stolen bag. Moreover, the compassionate mood extends to Stella herself and reaffirms the paramount role of fashion items and brands, not only in the construction of her social image, but also in

${ }^{60}$ Corva, Glam cheap, p. 204.

${ }^{61}$ Corva, Glam cheap, p. 208. 
her self-esteem: 'siamo un po' finte tutte e due $[. .$.$] non valiamo molto sul mercato'. In$ this respect, by explicitly referring to her value in the marketplace Stella implicitly addresses neoliberal postfeminist ideas of self-promotion and individual freedom through the market, exposing how consumer culture defines and controls female subjectivity, which is first boosted and then cheapened by the same fashion accessory.

Meanwhile, Stella's husband undergoes a parallel transformation. Having temporarily converted their Milan apartment into a B\&B, while Stella is at work he has to take care of the French couple who is staying with them. In charge of domestic duties, he learns how to make bread, redecorates the place and more generally reinvents himself as a host. Incidentally, the guests are designers attending the 'Salone Internazionale del Mobile' (Milan's annual showcase of new trends in furniture and design worldwide), where they are presenting stylish home accessories and jewellery made with recycled materials, and because Glam cheap is after all a romantic comedy, this turns out to be the gateway to the happy ending. In the last chapter of the novel, Stella reflects on past events and, having experienced the social and personal costs of commodity culture, she realises that she does not want to succumb to a life 'con il cartellino addosso' ${ }^{62}$ She reunites with her husband and, to seal their renewed harmony, he gives Stella a ring that he has designed, made with European coins out of circulation after the introduction of the Euro. The symbolic nature of such a gift resides not so much in the commitment between wife and husband that the ring romantically reinstates, but rather (once again) in the more subtle reference to the 'value' of the characters' identities and whether or not they can

${ }^{62}$ Corva, Glam cheap, p. 227. 
be translated - recycled in fact - into contemporary society. Furthermore, from the husband's perspective the coins might be seen as a representation of his struggle to find a place in the new job market: both have been made redundant and are perceived as something 'from the past', and both eventually find innovative, 'flexible' ways to reclaim their place in the market. Indeed, readers learn that the ring has been positively received by the French designers, who will work toward its commercialisation.

Far from resolving the couple's financial situation, this narrative device serves the purpose of redefining the husband's position both in the story and in Stella's life. This is proven by the fact that Corva has him uttering the following sentence: 'fa ridere l'idea di un manager convertito in designer, anzi redesigner, ma ci proviamo, giusto? La parola d'ordine è riciclarsi ${ }^{63}$ Here the husband first laughs at the idea of a top manager moving into design but then acknowledges the fact that, in this time and age, one must be flexible. Interestingly, Corva discards the politically correct expression 'essere flessibili' in favour of the verb 'riciclarsi', which bears much more derogative connotations as it somehow implies a lessening of his skills. The sentence is also significant for the expression 'ci proviamo, giusto?', where the plural form gives voice to the husband's renewed participation in Stella's struggles, one that makes up for his previous emotional withdrawal in the story. Thus, Corva's finale seems consistent with what Ebert has argued about chick lit novels, which 'oscillate between ironically displacing and reinstating love with the right man - whose own property status is now

${ }^{63}$ Corva, Glam cheap, p. 228. 
more uncertain, ${ }^{64}$ Indeed, despite the sentimental happy ending that reinstates the emotional harmony between the couple, Corva's narrative underlines the precarious position of the male figure, whose position as the breadwinner remains ultimately in doubt.

\subsection{Conclusion}

The two novels that I have examined in this chapter (Voglio un mondo rosa shokking and Glam cheap) are exemplary of how Italian chick lit is addressing some of the issues pertinent to professional women in contemporary Italy. In particular, their plots revolve around a topic that in recent year has gathered substantial prominence, that is, the flexibility in the workplace against the social and cultural backdrop of posto fisso. Over recent decades national reforms have deregulated permanent employment contracts and pushed a large-scale liberalisation of the labour market toward flexible contracts, yet the posto fisso is a peculiar notion that is still hardwired in the psyche of many Italians, a state of mind that goes far beyond its immediate meaning in the working environment. In this context, both novels call attention to the composite reality of women and their different experiences in regard to such new 'mobile' working conditions. More specifically, they focus on middle-class professional women and how they answer to a labour market that demands flexibility but does not provide an equally flexible welfare. At the same time, Voglio un mondo rosa shokking and Glam cheap choose to present middle-class women who negotiate ideas of selfsufficiency in the working sphere through notions of empowerment, choice and self-

${ }^{64}$ Ebert, The Task of Cultural Critique, p. 113. 
determination borrowed from neoliberal postfeminist culture, highlighting their resonance in contemporary Italy.

Despite a similar point of departure, the two novels soon take antagonistic routes: on the one hand, the characters in Voglio un mondo rosa shokking emphasise the positive aspects of flexibility and self-employment and welcome them as an opportunity for choosing independently the types of work that suit their needs and ambitions; on the other hand, the protagonist of Glam cheap equates flexibility and atypical work with the loss of welfare protection and rights. While initially Stella, much like Sofia in Voglio un mondo rosa shokking, thanks her free-lancing days for the freedom and privileges they give her, it is only when her husband is made redundant that this assertive woman fully realises the dangers of such 'privileged' working conditions, reading a different reality into them: '[e]ro esaltata dall'idea di andare al mare quando tutti aprivano il computer in un ufficio con le finestre sigillate. [...] Ora darei non so cosa per passarci anche il sabato e la domenica, in un ufficio, magari con un Vero Contratto'. ${ }^{65}$

In this context, I turn once again to Ebert and her analysis of chick lit as 'the romance of postcontemporary cynical reason'. According to Ebert, chick lit narratives move beyond the focus on the male/female courtship plot and the idea of love as fulfilment to concentrate on stories of self-affirmation which may or may not include the conventional happy ending. Love is still part of the narrative but it is kept at ironic distance, as "chick lit cleanses romance of "corny love" [with] minimalist rhetoric

${ }^{65}$ Corva, Glam cheap, pp. 78-79. 
[and] bare realism'. ${ }^{66}$ This holds true for Voglio un mondo rosa shokking and Glam cheap, as both are undoubtedly chick lit novels of self-affirmation with little to no courtship plot, yet they depart from Ebert's reasoning insomuch as they still link selfaffirmation and emotional fulfilment to love. Not romance's 'corny love', though, but love in its two most traditional incarnations, that is, maternal love and heterosexual love. This is well on display in the case of Voglio un mondo rosa shokking, whose protagonist Sofia rejects her career ambitions when she finds 'l'amore più grande possibile', that is, a mother's love for her child. Such a statement overtly (and arguably) relies on the idea that it is solely within motherhood that women can become themselves, achieving a sense of profound balance and satisfaction inaccessible to childless women. Like fellow chick lit writer Federica Bosco, Canevari uses pregnancy as the 'motivational accident' that helps her character, a working single woman adrift in life, to find professional and emotional fulfilment. Yet, Bosco manages to stay away from the rhetoric of motherhood and invokes the audience's emotional response through humour and comedy. By contrast, Canevari's return to Invernizio's 'onnipotenza materna', not only ideologically but also stylistically, quashes the possibility of a narrative capable of delivering a shared and universal experience.

In this respect, Glam cheap offers a more balanced approach to the narrative tropes of popular romance and the issues of contemporary working women. Corva's female breadwinner ingeniously addresses professional identities and gender roles inside and outside the marketplace, but the writer struggles to keep the focus up to the end of the novel, when heterosexual love becomes once again the benchmark for issues such as

\footnotetext{
${ }^{66}$ Ebert, The Task of Cultural Critique, pp. 105-06.
} 
financial insecurity and unemployment. However, what prevents the novel from losing its focus, from a stylistic point of view, is a combination of both realism and comedy that makes the most of chick lit features, together with the presence of an equally strong male voice in the narrative that counterbalances Stella's and simultaneously enriches it.

While both novels mirror postfeminism's ambivalent discourses on gender, sexuality and relationships, I read their focus on issues that are specifically Italian such as precariato and flexibility as a significant effort to broaden chick lit's themes toward a local identity, pushing the novels beyond the limited space of derivative genre fiction. From this perspective, the next chapter will investigate a different attempt at exploring the possibilities of genre writing, one that is specifically based on intertextuality and parody. 


\section{CHAPTER 5 - Romance, humour and intertextuality: Stefania Bertola's romantic comedies}

\subsection{Introduction}

In this chapter, I conclude my investigation of Italian chick lit by looking at the work of Stefania Bertola (b. 1952), which offers an example of popular genre fiction that successfully negotiates traditional conventions and contemporary transformations. I focus on Ne parliamo a cena (1999), Aspirapolvere di stelle (2002), Biscotti e sospetti (2004), A neve ferma (2006) and La soavissima discordia dell'amore (2009), the five titles that constitute the core of Bertola's production. ${ }^{1}$ Thanks to a crafted layering of old and new narrative styles, in these novels romance and chick lit tropes are re-read through the lens of parody and intertextuality. Indeed, as we shall see Bertola's intertextual discourse operates on many levels and creates an ongoing dialogue among old texts, new ones and their readership.

In order to discuss Bertola's approach to chick lit and romance fiction, I draw from Celestino Deleyto's The Secret Life of Romantic Comedy, ${ }^{2}$ a study on romantic comedy films that aims at analysing the genre from both a cultural and historical point of view. Deleyto defines the romantic comedy as the genre 'which uses humour, laughter and the comic to tell stories about interpersonal affective and erotic

\footnotetext{
${ }^{1}$ Stefania Bertola, Ne parliamo a cena (Milan: Salani, 1999); Aspirapolvere di stelle (Milan: Salani, 2002); Biscotti e sospetti (Milan: Salani, 2004); A neve ferma (Milan: Salani, 2006); La soavissima discordia dell'amore (Milan: Salani, 2009). Bertola has also written a comic self-help manual on how to cope with a sentimental break-up and in 2010 has published a collection of short stories. She is an accomplished screenplay writer involved in the production of successful TV series for many Italian networks, for example the historical romance Elisa di Rivombrosa (2003-2005) and the comedy $I$ Cesaroni (2006-ongoing).

${ }^{2}$ Celestino Deleyto, The Secret Life of Romantic Comedy (Manchester: Manchester University Press, 2009).
} 
relationships'. ${ }^{3}$ The most innovative concept in Deleyto's analysis is that he moves the focus away from genre's narrative structures, which in romantic comedy must follow a rather predictable pattern, to draw attention instead specifically to the transformative power of the comic perspective. In Deleyto's view, the presence and scope of humour in romantic comedies has less to do with the enjoyment of these films than with the understanding of them; in fact, humour becomes instrumental for the interpretation of all the many issues and themes at work in the story. Certainly, writes Deleyto, romantic comedies draw from ideas about love and relationships that are specific to the cultural and historical moment in which they are created, and they always feature a tidy closure where these ideas are wrapped up in an emotionally satisfying (and predictable) ending, but it is humour that provides the unique angle from which these ideas are read and evaluated. The comic perspective, Deleyto continues, powerfully frames and accounts for the way the characters interact and evolve in spite of their sociocultural habits and constraints, creating 'a space of transformation and fantasy' where both the characters and the audience face and come to terms with the complexity of sentimental relationships. ${ }^{4}$

Although elaborated in the context of film genre studies, Deleyto's observations can be applied to genre novels as well, and in particular to Bertola's works, where humour and laughter play a fundamental role in the storytelling, creating the same kind of space of 'transformation and fantasy' through witty dialogues and quirky characters but, most importantly, by addressing various narrative codes and generic conventions. As I have noted elsewhere in this thesis, Italian popular romance has always been

\footnotetext{
${ }^{3}$ Deleyto, The Secret Life of Romantic Comedy, p. 30.

${ }^{4}$ Deleyto, The Secret Life of Romantic Comedy, pp. 45-46.
} 
permeated by a specific 'serietà assorta', 5 a distinctive tone of sombre seriousness that often borders into plain melodrama, which was considered necessary in order to support the educational message that the story was required to deliver to its (female) readers. While the genre may have gradually abandoned the 'serietà assorta' of its origins, nevertheless it has kept sheer humour and comedy persistently at a distance. By contrast, comedy and humour are the backbone of Bertola's writing, which reinterprets the genre through a crafted bricolage of many narrative codes and conventions.

But how does the comic element work in Bertola's romantic comedies? Here I turn to Margaret A. Rose's Parody / Meta-fiction, in which she discusses parody as 'a form of meta-fiction' or 'a technique of stylistic "imitation" and distortion'. ${ }^{6}$ Central to Rose's argument is the idea of parody as 'the meta-fictional "mirror" to the process of composing and receiving literary texts', ${ }^{7}$ a concept that she explains through the analysis of Jane Austen's Northanger Abbey (1818). Rose notes that Austen 'marks herself as a reader of the text, the value of which she is questioning [and] ironically mirrors her use of parody in the use of parody by one of her characters'; this way, the mirror adds to its 'mimetic' function a 'dialectical' one, as it works in several directions at once, inside and outside of the novel itself, making 'characters, author and reader [all] simultaneously the targets and the tool of satire' ${ }^{8}$ Rose also introduces the notion of the transformative power of parody, which she locates in its structure:

\footnotetext{
${ }^{5}$ Vittorio Spinazzola, L'immaginazione divertente: Il giallo, il rosa, il porno, il fumetto (Milan: Rizzoli RCS, 1995), p. 54.

${ }^{6}$ Margaret A. Rose, Parody / Meta-fiction (London: Croom Helm, 1979), p. 19.

${ }^{7}$ Rose, Parody / Meta-fiction, p. 59.

${ }^{8}$ Rose, Parody / Meta-fiction, pp. 70-72.
} 
[T]he structure of the parody - based on the imitation, quotation or distortion of the target text creates a dialectic of imitation and transformation, superseding the act of imitation itself, and uniting the parody work with another text and literary tradition, while at the same time changing the direction of this tradition through its refunctioning of its models. ${ }^{9}$

As we shall see, the process of imitation and transformation through 'imitation, quotation or distortion of the target text' holds with regard to Bertola's identity as a writer and is at the core of her engagement with romance fiction through humour and parody, and with popular and media culture alike. Before analysing Bertola's novels in detail, however, in the next part of the chapter I will examine her writing style, discussing its role in the creation of female-centred romantic comedies where the writer, the characters and the audience create an open community in which humour is the privileged standpoint to look at love, romance, friendship and family.

\subsection{Bertola's romantic comedy: female storytelling and narrative modes}

I will start by touching upon Bertola's first novel, Ne parliamo a cena, published in 1999 when the presence of chick lit in Italy was relatively small and consisting mainly of translations. ${ }^{10}$ Even though the novel predates the genre's first appearance in Italy, it deserves critical attention because it presents all the traits that would become trademarks of Bertola's romantic comedies, such as an assorted group of women linked by family ties or long-time friendships, multiple storylines and the use of

\footnotetext{
${ }^{9}$ Rose, Parody / Meta-fiction, p. 158.

${ }^{10}$ In various interviews Bertola has addressed the genre with mixed feelings, criticising in particular the excessive importance given to themes such as finding a man and losing weight but expressing her admiration for Sophie Kinsella's The Secret Dreamworld of a Shopaholic and its protagonist. See Wanda Marra, 'Stefania Bertola: scrivo per divertire', RaiLibro: settimanale di letture e scritture, Railibro, 2007 <http://www.railibro.rai.it/ interviste.asp?id=66> [accessed 15 December 2007]; 'Intervista a Stefania Bertola' in Lookout, $2008<$ http://www.lookout.it/lktmagazine1/index.php? section=10\&issue_id=24\&content_id=224> [accessed 22 February 2008].
} 
comedy and humour as the main tool to narrate them. Indeed, the originality of $\mathrm{Ne}$ parliamo a cena rests on the attempt to bring together comedy, humour and popular romance, anticipating some of the strategies that other writers in the genre would adopt later, after the massive diffusion and commercial success of Anglo-American chick lit. In this respect, Ne parliamo a cena remains significant in Bertola's production for the use of the first person narrator and a relatively free structure, showing a clear intention to experiment with some of the modes typical of chick lit such as the real-time chronicle or diary style. Instead of the traditional division into chapters, for example, Bertola opts for a continuous first person narrative in the present tense, interrupted by small-capped headings that signal plot advancements through changes in the time and location of the events, for example 'ORE 21.30. CASA MIA', 'ORE 13.00. PIAZZA CAVOUR' and so on. Thus, the novel opens in media res, with Costanza addressing the audience directly:

A me il rotolo della zia Margherita non è mai riuscito. [...] Quando provo a farlo io, viene fuori un agglomerato di briciole e panna. Mia cugina Veronica, invece, lo esegue alla perfezione. La stessa zia Margherita ammette che il rotolo di Veronica potrebbe servire da modello alle giovani generazioni. La cosa sotto sotto la scoccia, perché Veronica non è sua figlia: è sua nipote, come me. La figlia della zia Margherita è mia cugina Irene, che a quanto mi risulta non ha mai nemmeno tentato di preparare il famoso rotolo. Quando gliene serve uno, lo chiede a mamma. Sofia è in grado di farlo, e in passato ha ottenuto risultati eccellenti, ma di recente di cucinare non se ne parla, e i dolci si limita a consumarli in eccesso. E così restiamo io e Bibi. Di me ho detto. In quanto a Bibi, al rotolo della zia Margherita non si avvicina neanche, per timore che qualche caloria volante le salti addosso, figuriamoci prepararlo. ${ }^{11}$

This opening creates an immediate sense of participation by drawing the reader into a tightly-knit community of women where all characters are defined by their relationship with 'il rotolo della zia Margherita', a cake whose recipe is handed down from a

${ }^{11}$ Bertola, Ne parliamo a cena, p. 5. 
generation of women to another. The tone is of casual conversation, with interpolated clauses, comments and digressions, and the overall effect evokes a rather informal chat among friends; as such, it is certainly effective in anticipating the novels' main focus, that is, female solidarity.

At this point the narrator proceeds to put the characters in context by introducing the 'Cena delle Cugine', a community that she subsequently explains in detail:

La Cena delle Cugine è una ricorrenza periodica, a cadenza variabile, che si svolge a turno a casa di tutte tranne Veronica. Perché Veronica ha qualcosa che la distingue da noi quattro, un suo tratto caratteristico che la rende unica nel panorama delle cugine: è sposata, e suo marito non l'ha ancora piantata. [...] La procedura della Cena delle Cugine è semplice: ci si aggiorna rapidamente sugli affari delle cugine in generale, e poi si passa a esaminare con accanimento dialettico una particolare cugina. ${ }^{12}$

The 'Cena delle Cugine' is a female-only dinner in which five cousins (Costanza, Bibi, Veronica, Irene and Sofia) share and relentlessly discuss 'gli affari delle cugine', in the form of personal issues that range from love to children, from sex to friendship. Three of them are divorced, one is married, and they all have children except Costanza, the narrator, who is single but has a relationship with a married man. Each cousin is constructed to be representative of a stereotypical female character from popular romance and chick lit, holding different beliefs and expectations when it comes to sex, relationships and romance. Yet, we soon see the characters delivering a comic and self-mocking impression of the stereotypes they embody, offering a form of female storytelling that brings chick lit features into the context of Italian popular romance. For example, at the beginning of the novel Costanza introduces herself as follows: '[Io] da sedici anni sono l'amante di un uomo sposato che da un momento all'altro,

\footnotetext{
${ }^{12}$ Bertola, Ne parliamo a cena, pp. 5-6.
} 
ormai è questione di settimane, lascerà sua moglie per me'. ${ }^{13}$ Here Costanza's delusional relationship with her lover Alex is rendered through a self-deprecating humour that plays on the contrast between her adamant confidence that he will break up with his wife 'da un momento all'altro', and the fact that she has been waiting sixteen years for this momentous event to happen - inevitably casting an ironic light on the character's name, which translates the English perseverance (or indeed Constance). Later on, toward the end of the novel, reflecting on the fact that she always falls in love with handsome yet obnoxious men, Costanza comments 'Mi viene un senso di noia', ${ }^{14}$ poking fun not only at her own perseverance (now turned into boredom), but also, more subtly, at the boringly formulaic stereotypes of romantic fiction.

The way Bertola deploys chick lit's self-deprecating humour is perhaps clearer when Bibi, asked about the quality of her sexual life in the middle of one of the many ‘Cena delle Cugine', remarks: 'Alla grande. Walter non smetterebbe mai. Purtroppo io sono frigida. Ma questo è un altro discorso. [...] E tu, Costanza? Sei frigida anche tu?'. ${ }^{15}$ Bibi's way of addressing sexual matters comes across as genuinely amusing thanks to the sentence's structure, where the character initially presents herself as a sex enthusiast and immediately after elaborates that such enthusiasm is thwarted by her lack of sexual response, then turning the self-deprecation into comedy by asking Costanza about her sexual satisfaction. ${ }^{16}$

\footnotetext{
${ }^{13}$ Bertola, Ne parliamo a cena, p. 8.

${ }^{14}$ Bertola, Ne parliamo a cena, p. 176.

15 Bertola, Ne parliamo a cena, p. 15.

${ }^{16}$ Bertola's approach to sexual matters might appear to echo the tone of TV show Sex and the City, but it should be noted that when her novel was published, the TV series had not arrived in Italy yet (a dubbed version would be broadcast a year later).
} 
In this respect, a further stylistic feature worthy of note is the way in which the first person narrator is used to reinforce the link between the group of women and the readers, signalling Bertola's intention of writing about women and for women. It is not by chance that the men of Ne parliamo a cena are confined to marginal spaces or act as mere onlookers, as the following excerpt amusingly exemplifies: 'L'unica di noi cugine che non è figlia di una zia è Veronica. Suo padre è il fratello Botto maschio. Si chiama Ernesto, e in questa storia non comparirà mai più'. ${ }^{17}$ Although Costanza remains the novel's focal point, throughout the novel her chronicle of events is enriched with colloquial remarks or rhetorical questions that underline its dialogic nature, which becomes overt in sentences such as 'È bene che sappiate che in generale io detesto la gente che balla', 'La giornata non è, ripeto non è, finita', and 'Vi potete benissimo immaginare quale sia il mio livello di fascino ed eleganza in questo momento, mezza infilata in un bidone dell'immondizia'. ${ }^{18}$ In these occasions, Costanza addresses the readers directly, inviting them to share her thoughts or become part of the group, and indeed it is worth noting that the novel's title, 'ne parliamo a cena', seems to anticipate this intention of connecting the audience to the characters: the concept of the dinner-table talk conveys the image of a welcoming community, particularly in the Italian social and cultural landscape, and suggests that the book is an invitation to sharing, not just meals but also memories.

However, from Aspirapolvere di stelle on, her second novel published in 2002, Bertola abandons the first-person mode in favour of an omniscient third-person perspective. This narrative device offers her the chance to deal with the conventions of

\footnotetext{
${ }^{17}$ Bertola, Ne parliamo a cena, p. 50.

${ }^{18}$ Bertola, Ne parliamo a cena, p. 99, p. 49 and p. 170, respectively.
} 
traditional and contemporary popular romance in a more compelling way, specifically through multi-protagonist stories where female and male characters are given equal visibility. Instead of using one main protagonist to weave multiple subplots, Bertola connects the various characters through a narrative tone and a polyphonic voice, to the extent that it is the community of characters, rather than the single protagonist, that becomes the central focus of the story. In Biscotti e sospetti, for example, this shared narrative space is physically embodied by the building where all the characters live, a unity of space where their respective storylines build up.

In order to achieve such a consistent tone Bertola adopts an external omniscient narrator but constantly switches between external and internal points of view, either reporting or adopting the characters' actions and thoughts. This technique is particularly useful for introducing humorous commentaries, in the sense that these switches in narrative mode alter the reader's reception and understanding of the characters. A good example can be found in A neve ferma, where one of the protagonists keeps a journal and in various occasions Bertola inserts passages excerpted from it. Because the character in question is a young woman who is interested only in popular magazines and commercial TV shows, the writing is drenched in the colloquial tone of a girlish and frivolous chitchat, as in the following quote: 'E poi, caro diario, a te lo posso dire: credo di aver trovato l'amore. Sì... appena l'ho visto, ho sentito un tuffo al cuore [...] È bellissimo. Fai conto, bruno con gli occhi grigi, ho detto tutto... divino!!!!'. ${ }^{19}$ These journal entries not only back up the character's personality as it emerges from the plot, but thanks to the first person mode they also allow the reader to see the character under a different light, one that

\footnotetext{
${ }^{19}$ Bertola, A neve ferma, p. 96.
} 
simultaneously reinforces and mocks her traits. Another example of Bertola's technique comes from Aspirapolvere di stelle, where the writer uses a free indirect discourse that combines third person narrator, first person narrator, and external omniscient narrator:

Sono fantastica, pensava. Nessuna di queste slavate schiave del dovere potrebbe immaginare che nel mio cuore di perfetta e amorevole madre brucia un vulcano di passione (in effetti, Arianna aveva ricominciato a leggere gli Harmony). Sono una vera donna moderna, che concentra in sé la madre, la femmina, la compagna, l'imprenditrice... proprio come in un articolo di 'Marie Claire'!

In the first sentence, the third person is used to introduce Arianna's thoughts: 'Sono fantastica, pensava'; in the second and third, Arianna takes over in the form of an upbeat voice in the first person. But it is the phrase in brackets that shows how Bertola deploys the omniscient narrator. A few paragraphs earlier, Arianna says that she is not interested in Harmony romances; however, because the way in which she talks is indeed modelled on romance stock phrases (such as 'nel mio cuore [...] brucia un vulcano di passione'), the omniscient narrator intervenes to point out that Arianna is in fact reading such novels.

At the same time, the above passage offers the chance to discuss Bertola's interest in the forms and conventions of chick lit and popular romance. On the one hand, Arianna's final line is a clever nod to Bridget Jones's famous definition of the ambiguous relationship that chick lit characters entertain with glossy women's magazines and the utterly unachievable models of femininity they present, that is to say, the 'child of Cosmopolitan culture [...] traumatised by supermodels and too many

${ }^{20}$ Bertola, Aspirapolvere di stelle, p. 78. 
quizzes'. ${ }^{21}$ On the other hand, the reference to 'gli Harmony' shows Bertola's engagement with the local tradition: as we have seen in Chapter 2, Harmony is the joint-venture between Canadian publisher Harlequin Enterprises and Italian Arnoldo Mondadori Editore, and currently it is the leading publisher of popular romance in Italy. $^{22}$ Since its debut in the early 1980s, the simple mention of the word 'Harmony' has been enough to evoke embarrassing readings, and over the years Harmony has become shorthand for cheap writing and trashy novels, regardless of the genre they belong to. While in the excerpt above Bertola predictably plays on the stereotype of the unsophisticated woman duped by these readings, in Ne parliamo a cena she chooses a more interesting approach to popular romance and its place in Italy's literary scene. After years of being a quiet stay-at-home mother, Veronica lands a well-paid contract with Harmony, and her family's reaction is self-explanatory: 'Scrivi Harmony? Gli Harmony?'. ${ }^{23}$ The italicised definite article plays on the notorious fame that accompanies the publisher in Italy's sociocultural landscape and effectively conveys a sense of disbelief that is borderline judgmental, to which Veronica reacts by explaining that being an accomplished writer in such a thriving genre will finally give her some independence, both in the personal and the professional sphere. Veronica's position is interesting because it focuses not on the type of fiction she has chosen to write - the culturally biased mass-market romance - but rather on her writing skills in a highly specialised genre where competition is fierce, addressing the debate around women's allegedly inappropriate reading and writing habits. I shall return later to

${ }^{21}$ Helen Fielding, Bridget Jones's Diary (London: Picador, 1996) p. 59.

${ }^{22}$ According to Harmony's website, the latest sales figures account for 5 million copies sold each year, with around 50 titles released monthly (mostly translations of British and American books): <http://www.eharmony.it/Chi-siamo/Harmony-Italia> [accessed 1 March 2011].

${ }^{23}$ Bertola, Ne parliamo a cena, p. 214. 
Bertola's complicit relationship with mass-market popular romance; for now I just want to highlight how in passages like the one above she is using Rose's aforementioned double purpose of parody, that is, of contempt and sympathy, with both destructive and reconstructive functions. ${ }^{24}$

Finally, a further significant example of Bertola's use of the external narrator comes from La soavissima discordia dell'amore and deserves to be quoted at length:

Vista dall'aereo in volo sulla città, la notte scintilla, ma di tutte quelle luci a noi ne interessano soltanto tre, che formano un breve arco da ovest a est. Alle ventidue e quaranta di questa sera di maggio, la prima è la luce di Teresa, in corso Orbassano 237, a sudovest della città. Teresa è in cucina e sta preparando le milanesi, che il giorno dopo Arturo porterà via con sé. Arturo e Teresa vivono insieme da tre anni e tra sedici giorni si sposeranno, ma vorrebbero tanto lasciarsi.

La seconda luce è fioca, e appartiene a un abat-jour appoggiata accanto a un divano in una mansarda al quinto piano di una vecchia casa in piazza Madama Cristina [...]. Sul divano c'è Margherita: ha in mano quello che sembrerebbe un copione teatrale, ma la sua attenzione e la sua energia sono totalmente assorbite da un cellulare accanto a lei. Sta cercando di indurlo a suonare.

La terza luce proviene da una televisione accesa in un alloggio di Lungo Po Antonelli angolo via Oslavia, a sudest della città [...] Emilia sta guardando Edward mani di forbice, il suo film preferito. Intanto, ma molto lontano da lì, suo marito torna finalmente a casa dopo una lunga giornata di lavoro. Sopra queste luci passa ignaro l'aereo di Agnese, che alle ventidue e quarantacinque atterra all'aeroporto di Caselle. ${ }^{25}$

In this opening of the novel, the visually descriptive language of the external narrator is reminiscent of film screenplays, emphasised by the use of the present tense. In a long montage sequence, from a (literally) aerial shot the narrator cuts to close-ups that introduce the four main characters: Teresa, Margherita, Emilia and Agnese. Lengthy sentences and subordinate clauses provide movement to the description, creating a visual progression that depicts each character in well-crafted narrative snippets. Indeed, far from being merely descriptive, the passage tells us that even if Teresa and her

${ }^{24}$ Rose, Parody / Meta-fiction, pp. 28-30.

${ }^{25}$ Bertola, La soavissima discordia dell'amore, p. 9. 
fiancé would like to break up, they happily share a flat where she cooks for him; that Margherita is somehow involved in theatre and is waiting for an important call, presumably from a man. It tells us also that Emilia has a husband who lives far away from her, and that the four women live in Turin, since Agnese's plane has just landed at Caselle, the city's international airport. Despite the rather formal tone of the writing, a veiled yet palpable comedic touch emerges from the descriptions, for example in Margherita's hard concentration on making her mobile phone ring but particularly in the way the narrator points out that Emilia's husband is going home 'molto lontano da li', suggesting that the two characters are in fact separated.

All the passages discussed so far reveal a recognisable style throughout the body of Bertola's works, one that uses humour and comedy to give voice to a variety and complexity of women's issues; where such a voice proves to be particularly effective is not only in the new life it gives to popular romance, but also - and most importantly - in the demystification of its rules and conventions. In fact, Bertola's demystification exploits the conventions of popular romance and chick lit, disrupting their usual frame of reference and offering an intertextual reading of their multilayered (and often underappreciated) complexities.

\subsection{Comedy, romance and intertextuality in Bertola's fiction}

In his study on the language of humour, Walter Nash argues that 'a test of good parody is not how closely it imitates or reproduces certain turns of phrase, but how well it generates a style convincingly like that of the parodied author'. ${ }^{26}$ The focus here is on the writer's 'creative allusiveness', which directs the audience toward either a specific

${ }^{26}$ Walter Nash, The Language of Humour (London, New York: Longman, 1985), p. 84. 
author or text or, more generally, on 'pseudoparody', which Nash defines as the technique that evokes 'a hazy recollection of rhetorical procedures' that readers would immediately recognise as familiar. ${ }^{27}$ More recently, in discussing the dynamics of repetition and innovation in contemporary media, Umberto Eco has drawn attention to a specific kind of 'intertextual dialogue', focusing not so much on the stylistic quotation (Nash's concept of pseudoparody) but specifically on the presence in texts of 'explicit and recognizable [quotations] which blatantly and ironically play on intertextuality', and in particular on what he calls 'the ironic quotation of the commonplace'. ${ }^{28}$ This kind of quotation implies an understanding between the author and the audience inasmuch as, in Eco's words, '[w]e have texts that are quoted from other texts and the knowledge of the preceding ones - taken for granted - is supposed to be necessary for the enjoyment of the new ones' ${ }^{29}$ The acknowledgement of a shared 'intertextual encyclopedia' is thus instrumental to the comic effect, resulting from the audience's expectations with regard to a specific commonplace and its actual outcome, which is often achieved by disrupting or distorting it. As a result, while reaffirming the commonplace, both the author and the audience invoke ironic or reflective ambivalence toward it.

Nash and Eco's analysis of parody and quotation can be successfully applied to the analysis of Bertola's fiction. Her novels draw on ideas like pseudoparody and intertextual encyclopedia for a reinterpretation of romance fiction that is based on a dialogue between traditional manifestations of the genre and the comedic nature of

\footnotetext{
${ }^{27}$ All quotes are from Nash, The Language of Humour, p. 100 (italics in the text).

${ }^{28}$ Umberto Eco, 'Innovation \& Repetition: Between Modern \& Postmodern Aesthetics', Daedalus, 134 (2010), 191-207 (p. 197).

${ }^{29}$ Eco, 'Innovation \& Repetition', p. 198.
} 
chick lit, and it reveals different outcomes according to the ability of the reader to understand and interpret the connection between the new text and its original models. The first evidence of Bertola's intertextual quotation of chick lit elements is to be found in the 'sense of disillusionment' towards men and sentimental relationships in general highlighted by Tania Modleski in her assessment of the genre. ${ }^{30}$ While in Bertola's novels the courtship plot and the achievement of a solid, heterosexual relationship occupy a large part of the story, the narrative tropes are thoroughly reworked (and questioned) through humour and comedy. In Biscotti e sospetti, for example, right at the beginning of the novel the protagonist Violetta moves into a new apartment and meets Mattia, a handsome neighbour who immediately starts courting her. A good example of Bertola's 'sense of disillusionment' can be found in the following quotation, in which Mattia and Violetta discuss cheating:

'Lo tradisci ogni tanto? Perché se lo tradisci ogni tanto, io mi vorrei candidare.' Violetta lo guardò attentamente, poi sospirò. 'No. Non sei male, ma il tradimento non mi interessa. Non ho abbastanza carattere, per tradire. [...] bisogna saper mentire, saper sopportare il rimorso, avere una grande opinione di se stessi [...] Se proprio capitasse uno che mi fa innamorare da non capire più niente, allora prima lascio Eugenio, e dopo lo tradisco.'

Mattia sospirò. 'Quante storie... Innamorare da non capire più niente... guarda che uomini e donne sono più o meno tutti intercambiabili $[\ldots] \mathrm{O}$ sei ancora lì a credere alla persona del destino? ${ }^{31}$

In this witty dialogue, both characters talk about sentimental relationships in a way that is disenchanted to say the least. For example, Violetta says that she is not interested in cheating, but just because it is too complicated and she does not have the right attitude, not because it is morally wrong; in fact, Violetta concedes that, given the

\footnotetext{
${ }^{30}$ Tania Modleski, Loving with a Vengeance: Mass-Produced Fantasies for Women, $2^{\text {nd }}$ edition (New York: Routledge, 2008), p. xxv.

${ }^{31}$ Bertola, Biscotti e sospetti, p. 22.
} 
right circumstances, she may very well cheat on her boyfriend. The tone of the dialogue sets up a relaxed and casual conversation that is strongly reminiscent of chick lit techniques, subsequently reinforced by Violetta's comic attempt to maintain some sort of decorum by making it clear that she would dump her boyfriend first anyway (and thus invalidating the whole concept of cheating). Similarly, Mattia addresses and distorts the traditional romantic courtship not only by going straight to the point and chasing after what is, in actual fact, casual sex, but also by asserting that nowadays cheating is very frequent, the norm almost, thus mocking Violetta for her wishful thinking with regard to finding her true soulmate, 'la persona del destino'.

Interestingly, while all of Bertola's characters display a relaxed attitude toward sex and have many sexual encounters, these are never described. In Bertola's novels, emotionally-charged descriptions of the interaction between the characters are avoided altogether, as well as the more prosaic and steamy scenes typically associated with the popular romance. Rather, the sexual tension is built (and eventually released) through witty if not plain comic dialogues and situations. For example, Mattia offers to cheer up a distressed Violetta as follows: 'Che faccio? Ti bacio per consolarti e poi da cosa nasce cosa e finalmente faremo l'amore?', to which she laconically replies 'No, guarda, non è proprio il momento'. ${ }^{32}$ A similar dialogue takes place even more bluntly near the end of the novel, when the two characters have the following conversation over breakfast:

'Non vuoi sapere quando torno? Quando ci rivedremo? Che ne sarà di noi? Se abbiamo solo passato la notte insieme o se c'è di più?'

Lei ridacchiò. 'E tu? Vuoi saperlo?'

Mattia le andò vicino e la baciò molto.

${ }^{32}$ Bertola, Biscotti e sospetti, p. 193. 
'Io lo so.'

'Okay, allora prima o poi confronteremo le nostre informazioni. ${ }^{33}$

Here Bertola's delivers a happy ending that is predictable yet unexpected all the same: finally the characters have spent the night together, but readers have not seen them actually doing it, and their verbal exchange makes fun of all the stereotypes regarding the awkwardness of the morning after. Nonetheless, Mattia's kiss gives the scene an emotionally satisfying closure, leaving no doubt about their blissful future as a couple.

A further example of the distortion of sentimental narratives comes from Aspirapolvere di stelle, where in the middle of a quarrel Gabriele confesses his love to Ginevra with a dramatic 'perché ti amo'. But as the excerpt below demonstrates, Bertola immediately puts under comical scrutiny this fundamental trope of popular romance:

'Mi può venire in mente' le spiegò con pazienza Gabriele, 'perché ti amo'. Si bloccò, sconvolto lui stesso da quello che aveva appena detto. Mai e poi mai, in tanti anni di dedizione alla femmina, aveva pronunciato quella formula spaventosa. Aveva detto di tutto, dal desolante "Lo sai che a te ci tengo" all'ingannevole ardente "Ti adoro" [...] Per fortuna, la stasi temporale passò inosservata perché si era bloccata anche Ginevra, a cui nessuno aveva più detto "ti amo" dai tempi di un remoto fidanzato giovanile. [...] Ma un "ti amo" così, a dieci centimetri, con quegli occhi fiammeggianti, be', era qualcosa. ${ }^{34}$

Here Bertola reassesses the hero's momentous utterance of 'I love you' by showing both Gabriele and Ginevra taken aback by it: the impenitent bachelor Gabriele cannot believe that he has just uttered 'quella formula spaventosa', which he has always avoided and paraphrased with less compromising wordings, and realises that his attitude toward commitment has changed just because he has been able to finally say

${ }^{33}$ Bertola, Biscotti e sospetti, p. 227.

${ }^{34}$ Bertola, Aspirapolvere di stelle, p. 86. 
it; Ginevra, who on her part is aware of Gabriele's feelings but is not ready to reciprocate them yet, admits to herself that such fervent words are indeed 'qualcosa'.

On a similar wavelength, at the end of Ne parliamo a cena Lorenzo abruptly proposes

to Costanza, but she does not quite like the idea of getting married:

'Scusa, ma perché dobbiamo proprio sposarci? Se vuoi, viviamo insieme. Porti le tue cose qui, e vediamo come va.' [...]

' $[\mathrm{N}]$ on voglio vivere insieme. Preferirei fare qualcosa di leggermente più rischioso. Sposiamoci. Facciamo tutto il percorso misterioso: le carte, i testimoni, la mattina delle nozze, l'assessore. Non è che preferiresti sposarti in chiesa? [...] Allora è deciso: municipio. Però tutta vestita bella da sposa. Così puoi metterti addosso la cosa nuova e la cosa vecchia, la cosa prestata e la cosa blu.' [...]

'Lorenzo, i tuoi non mi sembrano motivi seri per un passo tanto...'

'Non dire "importante", eh? Non dire mai quella frase, 'passo importante'. Non la voglio sentire mai uscire dalla tua bocca. Certo che non sono motivi seri. Non ci si può sposare per motivi seri, dai!' [...]

'E per cosa, ci si può sposare?'

'Per sconsiderato amore'.

Allora sì, non posso fare altro che dirgli di sì. ${ }^{35}$

The whole passage does a remarkable job in dissecting the stereotyped language of romance fiction while simultaneously reinforcing its place and meaning in the narrative. Surprisingly, it is Costanza who comes across as non-committal, while Lorenzo pushes for a risky but more exciting form of commitment like marriage. The fact that he wants a conventional white wedding, down to the something old, something new, something borrowed and something blue tradition, should make him the perfect catch for the typical popular romance protagonist, yet his overwhelming enthusiasm appears too childish to Costanza, who underlines the lack of 'motivi seri' in his proposal. But Lorenzo shows deep annoyance with Costanza's conventional

${ }^{35}$ Bertola, Ne parliamo a cena, pp. 204-05. 
view of marriage as the defining moment of their relationship, arguing that marriage is absolutely not a 'passo importante' and that serious obligations are not a good reason to get married. In fact, he continues, the only good reason should be unreserved love, and at this point, in truly romance style, Costanza's only option is to say yes.

In both circumstances, the effect of this framing is exemplary of how Bertola follows the genre's rules while simultaneously exposing its commonplaces to the audience, where romance is equally dismissed and held up. As the turning point of any sentimental relationship in romance fiction, both Gabriele's abrupt 'perché ti amo' and Lorenzo's proposal maintain their pivotal role in establishing a lasting, heterosexual relationship, yet they do it in a decidedly parodic way. Moreover, it is now easy to see how this comic perspective effectively constructs that space of 'transformation and fantasy' proposed by Deleyto, as humour helps the characters (and readers alike) in understanding each other and negotiating intimate matters.

Characters's names and descriptions are another feature that, in Bertola's hands, offers a self-reflexive and comic reference to the tradition, this time specifically Italian, with varying degrees of subtlety. In analysing the works of Carolina Invernizio, Marina Federzoni has highlighted a canonical rule of the genre in the function of names, which provide basic information about the characters and anticipate their storyline to a large extent. Federzoni argues that this descriptive process works like a dictionary: ‘è un po' come leggere la definizione in un dizionario di una parola di cui non conosciamo il significato. [...] I nomi propri nell'I. rispecchiano il "carattere" del personaggio' ${ }^{36}$ Thus unusual and evocative names signal and make visible the

\footnotetext{
${ }^{36}$ Marina Federzoni, 'Carolina Invernizio', in Umberto Eco, and others, Invernizio, Serao, Liala (Florence: La Nuova Italia, 1979), pp. 29-59 (p. 35).
} 
heroine's uniqueness from the very beginning, and in Bertola's novels such names are Ginevra, Penelope, Emma, Morgana and Caterina, to name a few. Her choice is by no means accidental and serves a double purpose: on the one hand, she acknowledges the tradition by providing the character with an appealing or notable name that singles her out from the crowd; on the other hand, because of the clearly stated allusion to a wellknown historical or fictional heroine, the load of expectation that each name bears can be either confirmed or disrupted, engaging the audience in a richer reading experience. In Aspirapolvere di stelle, for example, the portrayal of Ginevra as a pale and beautiful widow torn between the love for two men alludes to Queen Guinevere of the Arthurian legend, which is then openly addressed in the case of her sister Morgana, who is indeed 'una perfetta Morgana: alta, pallida, capelli neri, occhi blu', ${ }^{37}$ the sensual and mysterious Morgan Le Faye borrowed from popular culture's iconography. Similarly, in Biscotti e sospetti the protagonist Violetta brings to mind Giuseppe Verdi's La traviata (1853) and indeed her participation in a quiz show about opera, one of the central elements of the plot, reinforces the connection to the Italian composer and his most famous character. But where her name proves to be truly meaningful is in the workplace, as Violetta is as shop assistant in a bookstore specialised in gardening and was able to get the job because, as her boss explains, '[non è] per niente semplice trovare [commesse] con nome di fiore'. ${ }^{38}$ Finally, Costanza of Ne parliamo a cena tells us that her name comes from her mother's obsession with Alexandre Dumas's The Three Musketeers (1844): 'In famiglia abbiamo questa passione per i nomi letterari, e

\footnotetext{
${ }^{37}$ Bertola, Aspirapolvere di stelle, p. 45.

${ }^{38}$ Bertola, Biscotti e sospetti, p. 24.
} 
mia madre considera I tre moschettieri il più bel libro che sia mai stato scritto, da cui Costanza'.39

The mimetic function of this narrative strategy becomes dialectical when Bertola implements it with chick lit tropes, in particular the use of popular culture celebrities to describe the character's features. In Aspirapolvere di stelle, Arianna and Ginevra are introduced as follows:

Come sempre, [Antonio] cercò di immaginare che attrici avrebbero potuto interpretare in un film... Quella più piccola e rotondina poteva essere una Kate Winslet bruna, ma con qualcosa di duro. Tipo Kate Winslet con la disposizione d'animo di Glenn Close. L'altra... be'... Una Gwyneth Paltrow? $\mathrm{O}$ addirittura una Grace Kelly? ${ }^{40}$

As I have discussed in the chapter dedicated to Federica Bosco, this is a narrative device that features prominently in chick lit, a genre based on the thorough knowledge of popular culture and media shared by the writer and the target audience. In chick lit, the reference to media culture celebrities is an 'intertextual encyclopaedia' that not only offers ready-made portraits of beautiful and successful women, but also holds cultural relevance, as their renowned status is often linked to memorable female characters in award-winning novels or movies. In the quote above, for example, KateWinslet and Gwyneth Paltrow played good-natured, brave and charming heroines in blockbuster movies Titanic (1997) and Shakespeare in Love (1998) respectively, gaining long-lasting recognition worldwide; by contrast, Glenn Close owes her enduring fame, both in the film industry and in popular culture, to her rendering of treacherously scheming women in movies such as Fatal Attraction (1987) and Dangerous Liaisons (1988).

\footnotetext{
${ }^{39}$ Bertola, Ne parliamo a cena, p. 11.

${ }^{40}$ Bertola, Aspirapolvere di stelle, p. 21.
} 
In deploying this familiar narrative device, however, Bertola differs from Bosco and other writers in that she openly discloses her purpose by using the phrase 'cercò di immaginare che attrici avrebbero potuto interpretare in un film'. This 'casting call', so to speak, exposes the intertextual fabric of the narrative and enriches the reading experience, as the audience is put in a dialectic position with the character who is trying to match the two women to famous actresses, who in turn is voicing Bertola's own reasoning. This strategy is taken a step further in the case of Jasmine Jay in $A$ neve ferma:

Jasmine Jay era esplosa con il suo primo film, il travolgente successo Rose in boccio, a cui erano seguite tante copie carbone, tutte modellate sullo stesso presupposto: liceale francese molto sexy ma fresca come l'acqua eccetera vive i suoi primi bla bla e le sue prime ecc. ecc. circondata da amici colì e colà e genitori bi e ba. ${ }^{41}$

The allusion here is clearly to French actress Sophie Marceau and her cinematic debut in La Boum (1980), the international box-office hit released in Italy under the title $I l$ tempo delle mele and acknowledged founder of many European teenage comedies. ${ }^{42}$ Bertola's technique in this passage works on two different levels: on the one hand, she introduces a fictional French movie star who became famous with her first movie and provides a brief synopsis of it; on the other hand, thanks to the tongue-in-cheek tone, the intertextual reference becomes metafictional if we read the movie's synopsis as a comment on the clichés of romantic comedies. As a result, rather than just offering a quick and passive reference, Bertola is alerting the reader to the multiple connections at work in the text and, in doing so, invites them to bring their own contribution to the narrative.

${ }^{41}$ Bertola, A neve ferma, p. 17.

${ }^{42}$ The movie immediately became an icon for generations of teenagers (myself included) and, since then, has held a prominent place in Italian popular culture. 
The characters' jobs are another area where Bertola addresses chick lit features specifically. The glamorous professions in the media or fashion industry typical of the genre are systematically replaced by rather unpopular and old-fashioned feminine occupations such as house-maid, seamstress, shop-assistant and trainee. In Aspirapolvere di stelle, for example, the three protagonists Penelope, Ginevra and Arianna run a cleaning and catering company called 'Agenzia Fate Veloci'. Each of them is specialised in a domestic task (, cleaning, gardening and cooking, respectively) and the company's services are in high demand among Turin's upper-class families. When they are hired by a critically acclaimed writer (Filippo Corelli) to perform domestic duties in his villa, the brief they receive describes the tasks in detail:

Quello che Filippo Corelli voleva dalle Fate Veloci era una perfetta e totale gestione di ogni faccenda domestica, dalle pulizie alla cura del giardino. Voleva cibi perfetti ma solo quando li avesse richiesti, voleva mobili lucidi e profumati, voleva un terrazzo accogliente anche nel cuore dell'inverno, voleva legna per il camino sempre ben impilata nelle ceste, voleva lenzuola profumate, camicie stirate, bagni schiuma che non finissero mai, dentifrici sempre nuovi, frigorifero sempre pieno ma sempre pieno di sorprese. E non voleva, invece, nessuno che gli parlasse, gli chiedesse, gli stesse fra i piedi, passasse davanti allo studio in cui lavorava. ${ }^{43}$

As we can see, the 'perfetta e totale gestione di ogni faccenda domestica' is intended literally and encompasses an endless list of impossibly exaggerated duties that, indeed, could be successfully carried out by magical creatures only. The 'domestic goddess' portrayed in popular media culture is upgraded to a better and more efficient 'domestic fairy', who does her magic and quickly disappears. By stretching this fantasy to its limits, Bertola plays on the supposedly natural competence of women in relation to the domestic duties and intensifies the gendered nature of such a fantasy in a way that is less denigrating than ironic.

${ }^{43}$ Bertola, Aspirapolvere di stelle, p. 23. 
Likewise, in A neve ferma the protagonist Emma is a pastry-chef apprentice with a university degree in History. Coming from a working-class background, Emma was encouraged by her parents to study and pursue a career in academia or in professions associated with a higher class or social status, which she however rejected:

Non voleva neanche diventare segretaria, avere un dottorato, lavorare in un ufficio stampa, correggere le bozze o scrivere sui giornali. No, guardando i programmi di cucina in tivù, Emma aveva capito che voleva guadagnarsi da vivere preparando torte, pasticcini, budini, creme ed eventualmente uova di Pasqua. ${ }^{44}$

Bertola here demystifies chick lit's ubiquitous trendy and middle-class professions such as journalist, editor and PA, creating a character who is as far as possible from the clichés of the genre, but at the same time she mocks Emma's fascination with the art of patisserie by linking it to culinary TV shows, calling on the television formats that have launched celebrity chefs worldwide and their prominent presence in popular and media culture. ${ }^{45}$

Finally, in Biscotti e sospetti Caterina proudly embraces her family's working-class tradition of seamstress but with a twist, as she specialises in quality clothes for blowup sex dolls: 'Io faccio vestiti per le bambole gonfiabili. [...] Sarta, non stilista. Sono una sarta come mia madre e la mia prozia, però in un altro ramo. Loro fanno vestiti per le signore vere'. ${ }^{46}$ This quote serves to illustrate how Bertola uses old-fashioned jobs to ironically comment on upwardly-mobile women in contemporary Italy: the humble

\footnotetext{
${ }^{44}$ Bertola, A neve ferma, p. 26.

${ }^{45}$ Indeed, the novel's plot revolves around a pastry competition to be broadcast live on TV and can be read as a parody of the many cooking-based reality shows currently available on television. In the last decade, American reality shows like Top Chef and Hell's Kitchen, or the British MasterChef, have acquired worldwide popularity, often resulting in local adaptations. In Italy, for example, the successful La prova del cuoco, on state-owned channel Rai Uno, is the localised version of BBC's Ready Steady Cook.

${ }^{46}$ Bertola, Biscotti e sospetti, p. 17.
} 
profession of 'sarta', reclaimed by Caterina as opposed to the modern and more glamorous 'stilista', frames her within the traditional feminine domestic sphere as her mother and her great-aunt before her. At the same time, those class-inherited skills are now updated and transferred 'in un altro ramo', one that could not be more edgy and sexually charged. As a result, Caterina effectively embodies dispositions that are antithetical to one another: chick lit's middle-class, smart and sexually savvy professional, and the working-class, modest and chaste labourer of the traditional popular romance.

But where Bertola's intertextual dialogue with chick lit clichés truly takes centre stage is in the obsession with beauty and appearance. As Rosalind Gill and Elena Herdieckerhoff have noted, in chick lit narratives 'the body is constructed in a highly specific way: it is a body that is always already unruly and which requires constant, monitoring, surveillance, discipline, and remodelling in order to conform to judgments of normative femininity'. ${ }^{47}$ For example, Bridget Jones famous complaint that '[b]eing a woman is worse that being a farmer - there is so much harvesting and crop spraying to be done ${ }^{48}$ is echoed in Marian Keyes's Sushi for Beginners, where Lisa describes her beauty routine as follows:

Lisa was clear-eyed about her looks. In her natural state - not that she'd been in that for a very long time - she was a pretty enough girl. But with huge amounts of effort she knew she'd upgraded herself from attractive to fabulous. As well as the usual attention to hair, nails, skin, make-up and clothes, she popped huge amounts of vitamins, drank sixteen glasses of water a day, only snorted cocaine on special occasions and every six months had a botulism injection in her forehead - it paralysed the muscles

\footnotetext{
${ }^{47}$ Rosalind Gill and Elena Herdieckerhoff, 'Rewriting the Romance', Feminist Media Studies, 6 (2006), 487-504 (p. 498). In this essay, the authors argue that such portrayal of beauty and body in chick lit highlights 'a distinctive post-feminist sensibility in contemporary culture' (ibid.).

${ }^{48}$ Helen Fielding, Bridget Jones's Diary (London: Picador, 1996), p. 30.
} 
and gave a lovely wrinkle-free appearance. For the past ten years she'd been constantly hungry. So hungry that she barely noticed it now. ${ }^{49}$

While in every novel Bertola introduces a character who fits this description, such as Ginevra in Aspirapolvere di stelle and Costanza in Ne parliamo a cena, she does not belittle it; rather, she treats it as a generic commonplace that needs to be addressed ironically. Read against Keyes's quote above, the following excerpt offers a good example of how Bertola recasts the trope:

A differenza della Regina Grimilde, che allo specchio, specchio delle sue brame, chiedeva sempre chi fosse la più bella del reame, la signora Elena al rettangolo argentato faceva questa domanda, sempre la stessa:

"QUANTI ANNI DIMOSTRO? I tre diversi tipi di crema che ogni mattina e ogni sera mi spalmo sul viso, collo e décolleté, servono? Il morbido gel con cui contorno a regolari intervalli occhi e labbra compie il lavoro per cui lo pago, e anche caro? [...] Il biondo dorato dei miei capelli comincia a svelare la sua natura chimica mediante il semplice contrasto con le sopracciglia? Quale tipo di luce dissimula meglio le fini zampe di gallina che sventagliano ai lati dei miei occhi? E gli stramaledetti contorni del viso? Hanno ceduto un po', questi bastardi, non contenti delle molte misure che prendo per non mostrare al mondo il volto spesso della mezza età". ${ }^{50}$

In this monologue played in front of the mirror, itself one of the most distinctive tropes

of romance fiction, Bertola borrows one of the most famous quotes from Snow White

to introduce the character of Elena, who anxiously scrutinises her look while giving a

meticulous report of the 'huge amounts of effort' she puts into defy ageing and

maintaining an image of youth and normative femininity. Indeed, a few paragraphs

later she continues:

Elena si addolcì un po' scendendo a osservare l'impeccabile tenuta del fisico. All'apparenza era tutto ancora snello e sodo. [...] Posso passare ancora per una quarantenne, pensò con sollievo. Trentottenne perfino, to'. E la signora Elena, che di anni ne aveva cinquantaquattro, affrontò l'ultimo, doloroso compito di ogni mattina: pesarsi. Cinquanta grammi più di ieri. Quindi, oggi, solo verdura. (ibid.)

${ }^{49}$ Marian Keyes, Sushi for Beginners (London: Michael Joseph; Penguin, 2000), p. 95.

${ }^{50}$ Bertola, A neve ferma, pp. 20-21. 
Antonia Arslan and Maria Pia Pozzato read the trope of the mirror present in romance fiction against the literary backdrop of decadentismo and locate its function in the 'rituale feticistico dell'autocontemplazione' typical of that literary movement; ${ }^{51}$

Giovanna Rosa focuses instead on the representation of the female body, which the mirror not only reflects and contemplates, but also minutely scrutinises and dissects: 'il corpo femminile [...] si offre, attraverso la propria imagine riflessa, a un'ammirazione incondizionata non meno che alienante'. ${ }^{52}$ In Bertola's quoted passage, such rapturous contemplation of the female body is acknowledged in order to become the object of a well-executed parody: we see Elena posing rhetorical questions, jeering at the supposedly miraculous properties of her beauty treatments and literally swearing at her own flaws, such as 'gli strameledetti contorni del viso, questi bastardi'. Similarly, the endless list of beauty products she needs in order to conceal her age, as well as her dieting efforts, evoke the neurotic and expensive makeover of the female body that so often recurs in chick lit. This way, Bertola quotes and imitates key tropes from both genres, romance and chick lit, but, at the same time, she distorts them in a way that makes parody out of Elena's obsession with preserving her youth.

Not surprisingly, male characters undergo a similar treatment: they might be temperamental, have striking features or be well upward in the professional ladder (they are typically doctors, notaries, writers and scholars), but these stock characteristics are always cleverly managed, such as in the case of Mattia in Biscotti e sospetti: 'Mattia era bello senza vergogna, alto e spigoloso, fremente di energia, con

\footnotetext{
${ }^{51}$ Antonia Arslan, and Maria Pia Pozzato, 'Il rosa', in Letteratura Italiana, Storia e geografia, III, ed. by Alberto Asor Rosa (Torino: Einaudi, 1989), pp. 1027-46 (p. 1040).

${ }^{52}$ Giovanna Rosa, 'Lo specchio di Liala', in Il successo letterario, ed. by Vittorio Spinazzola (Milan: Unicopli, 1985), pp. 37-69 (p. 56).
} 
gli occhi tutti luccicanti e capelli di quelli che ti viene subito voglia di toccare' ${ }^{53}$ In introducing this shamelessly handsome male character, Bertola's phraseology simultaneously acknowledges and parodizes the clichéd language of the genre. In Aspirapolvere di stelle, the same device is applied to bestselling writer Filippo Corelli, whose striking features and passionate prose make him particularly successful among female readers:

Era una specie di Brad Pitt padano, profumato e vitale come un albero di arance. Era alto, forte, sorridente, era tutto dorato e appassionato, metteva felicità a vederlo, e tanto più seducente e misterioso appariva il contrasto con le sue occasionali malinconie

$[\ldots]$

Era più luminoso, più caldo e più profumato degli altri uomini. E che profumo... Cos'era? Non lo aveva mai sentito... E quel colore di capelli? Che biondo era? Non lo aveva mai visto. Anche l'azzurro degli occhi era di una sfumatura sconosciuta. Non proprio blu. Turchese. Non proprio celesti. Blu? Non troppo azzurri. Verdi $?^{54}$

Together with the reference to celebrity Brad Pitt, Corelli's good-looking features are so exaggerated that they become comic, as the meticulous yet unsuccessful attempt at capturing the exact shade of his eyes demonstrates. While such redundant description obviously recalls the stereotype of stunning and sensitive male heroes in popular romance, its parodic function in the narrative would pass unnoticed if Bertola had not previously cast Corelli as a narcissistic sexual predator, who relentlessly uses his good looks to seduce women:

Rimasto solo con le sue vittime, Filippo sorrise. [...] Che bello, quando soffrivano così, quando lo odiavano, pronte a sciogliersi d'amore e di perdono, potremmo dire di gratitudine, se appena lui avesse detto la mezza

\footnotetext{
53 Bertola, Biscotti e sospetti, p. 14.

${ }^{54}$ Bertola, Aspirapolvere di stelle, p. 62 and p. 65 respectively.
} 
parola, fatto il mezzo gesto. E che delizia non fare né gesto né parola, e vederla andar via trafitta. ${ }^{55}$

Because the main plot is based on the fact that all the female characters are unaware of Corelli's true nature and easily fall under his charming spell, thanks to this narrative device the audience is put in the position of truly enjoying the comic effect at work. By contrast, in the same novel Antonio Bassani is introduced as Corelli's temperamental assistant, but this time around Bertola moves away from popular culture references and opts for a rather odd description:

Vedeva davanti a sé un giovane uomo poco appariscente ma per niente brutto. Poteva forse definirsi bello? [...] Era molto elegante, ma in modo non convenzionale. E neanche anticonvenzionale. Aveva semplicemente addosso una serie di indumenti gradevoli che gli stavano bene. ${ }^{56}$

As usual the writer introduces the character through his outward appearance, but the rhetorical question ('Poteva forse definirsi bello?'), together with a clever use of adjectives, adverbs and adversative conjunctions ('un giovane uomo', 'poco appariscente ma per niente brutto') shift the description into a phrasing that, although reminiscent of romance tones, is rather unflattering when compared to those of other male characters. This downplayed description is instrumental in delivering Bassani's subordinate position and prepares the audience for the novel's final twist, when they discover that in reality he is the author of the passionate and bestselling novels credited to Corelli, as well as a sensitive and caring lover, thus becoming the real romantic hero of the story. ${ }^{57}$

\footnotetext{
${ }^{55}$ Bertola, Aspirapolvere di stelle, p. 137.

${ }^{56}$ Bertola, Aspirapolvere di stelle, p. 22.

${ }^{57}$ In a kaleidoscopic mix of intertextual references, we learn that the bestselling writer lives in Ferrara, where he owns an old villa with a beautiful garden, to which he is particularly attached. The reference here is clearly to Italian novelist Giorgio Bassani (1916-2000) and his critically acclaimed novel $\mathrm{Il}$ giardino dei Finzi-Contini (The Garden of the Finzi-Continis, 1962). In addition, it is worth noting that
} 
In the next section of the chapter, I will look in more detail at the intertextual strategies used by Bertola to address and critically revisit traditional Italian romance fiction (that is, romanzo rosa) through the lens of parody and comedy. As we shall see, Bertola's intertextual framework is also one of self-critical reflexivity: when analysing the texts themselves, it is clear that the object of the parody is the romantic fiction genre in which it is inscribed. In this context, the risk is that of restraining the writing within the boundaries of superficial imitation or passive reference, yet Bertola embraces both the romance tradition and its generic themes by working in close relation to aspects such as language and narrative codes, as well as literary references, and thus exploring the intertextual nature of genre writing.

\subsection{Parody and self-reflexivity}

In her study on parody and meta-fiction, Rose argues that parody is a transformative process which 'mirrors the process of composing and receiving literary texts'. ${ }^{58}$ As such, it can be read simultaneously as a form of homage and criticism, because while it positively reaffirms the genre's conventions of the original text, it also expresses critical reflexivity towards them. From this perspective, parody is also an intertextual process, one that at various times quotes, imitates and distorts generic tropes and generic discourses and constantly challenges the readership to detect (and appreciate) the subtext that makes parody work.

Bassani was called the 'Liala' of Italian literature by the Neoavanguardia in 1963. In advocating formal experimental writing and political engagement, Italian Neoavanguardia (or 'Gruppo 63') attacked popular novelists such as Bassani and Carlo Cassola mainly because of their conventional use of language and narrative structure.

${ }^{58}$ Rose, Parody / Meta-fiction, p. 59. 
Bertola's A neve ferma is one such novel where critical self-reflexivity and intertextuality on popular romance are exemplary of Bertola's engagement not only with the genre but also, specifically, with the Italian tradition. One of the main characters is an aristocratic lawyer who secretly reads romanzi d'amore and dreams of a love-life modelled on their characters, as the following excerpts shows:

Mario Mongilardi leggeva romanzi d'amore. Questa sua segreta attività era iniziata quando aveva nove anni, e passava le vacanze con sua cugina Ada, tre anni più grande, accanita lettrice dei Romanzi della Rosa Salani, che aveva trovato a mucchi nella soffitta di casa. [...] Mario aveva cominciato a spararsi Prima o Poi, Oltre gli Scogli, Sei giorni e altri significativi titoli. Poi, ormai assuefatto, era passato a più nobili autrici, e aveva letto tutta Jane Austen, le più significative fra le Brontë, Elizabeth Gaskell e via via, fino a Margaret Mitchell e Rosamund Pilcher. Naturalmente erano letture segrete, portate avanti con somma discrezione [...] Sul suo comodino sbandierava Clive Cussler, Stephen King e, quando voleva darsi un tono più intellettuale, Niccolò Ammaniti, ma nel cassetto chiuso a chiave c'era sempre un romantico romanzo femminile. ${ }^{59}$

The educated, professional male passionate about romance but ashamed to admit his guilty pleasure does not break any new ground, but what makes it interesting is that Bertola positions this narrative device in an intertextual framework that refers to a very specific literary background. Alongside critically sanctioned female authors such as Jane Austen, the Brontë sisters and Elizabeth Gaskell (1810-1865), and mainstream romance writer Rosamund Pilcher (b. 1924), she mentions the historical Italian imprint Romanzi della Rosa Salani, quoting real titles to back up Mario's extensive knowledge ${ }^{60}$ Here Bertola goes to the roots of the Italian tradition and, instead of making up romance titles by exaggerating their typical flamboyant style, she takes advantage of existing novels, hyperbolically called 'romantici romanzi femminili', and

\footnotetext{
${ }^{59}$ Bertola, A neve ferma, p. 94.

${ }^{60}$ All the cited novels were written by British novelist Elynor Glyn and published by Salani between 1925 and 1934, obviously in translation: Eleonora Glyn, Sei giorni (Florence: Salani, 1925); Oltre gli scogli: storia d'amore (Florence: Salani, 1926); Prima o Poi (Florence: Salani, 1934).
} 
links them to the literary canon. As a result, while it is up to the reader's awareness to notice and fully appreciate the reference, the centrality of the Romanzi della Rosa series is explained as the bait that would lure Mario into the underbelly world of women's fiction. The language and phrasing reinforce the idea of clandestine activities, as these are 'letture segrete' which Mario, borrowing the lexicon of drug addictions, 'aveva cominciato a spararsi' until he became 'assuefatto'. A few sentences later, the comic element is reappraised by the nod to manly writers such as Clive Cussler and Stephen King, but particularly to the critically acclaimed Italian pulp author Niccolò Ammaniti, whose books Mario puts on display 'per darsi un tono un po' più intellettuale'.

Moreover, Mario is depicted as an avid reader unable to separate fiction from reality and who constantly uses romanzi rosa to decipher people and situations, a narrative technique that is consistent with Rose's aforementioned observations on parody as metafiction in Austen's Northanger Abbey. ${ }^{61}$ Duped by these readings, Mario has been waiting for his true soulmate to come along, and when he meets his childhood friend Emma he convinces himself that she is the one:

Inevitabile, inaspettata, un giorno avrebbe incontrato LEI [...] la donna del destino, la magica fanciulla che avrebbe spazzato via tutte le altre, trasformandolo in un marito fedele e appassionato, proprio come i vari Conte Hubert e ingegner John e Darcy e Rochester dei suoi libri preferiti. E adesso, da vari indizi, aveva identificato questa nemesi dei sentimenti in Emma. Proprio come in una storia dei Delly, era una ragazza del paese, di bell'aspetto, colta, gentile, elevata, figlia di semplici ma oneste persone. [...] Una sola cosa lo disturbava. Doveva esserci, da qualche parte, un ostacolo. C'era sempre, nei romanzi. ${ }^{62}$

${ }^{61}$ The metafictional and intertextual elements are even more subtle when we note that Salani, the publisher of Mario's favourite 'romantici romanzi femminili', is also Bertola's publisher.

${ }^{62}$ Bertola, A neve ferma, p. 95. 
The passage reveals Mario's function in the narrative as a tool for self-reflexive criticism on romance fiction: just like in a story written by the French siblings Delly, Emma possesses all the traits of the typical romance heroine, as she is a 'fanciulla' of humble origins and is beautiful, honest and intelligent. At this point, to conform to the romance narrative structure and match the courtship plot that Mario has in mind, their relationship must encounter a barrier, 'un ostacolo' that would impede their union.

Here Bertola applies the parody to the romance trope of the barrier analysed by scholar Pamela Regis. ${ }^{63}$ According to Regis, the barrier that stands between the heroine and hero can be external, such as a physical separation and rules imposed by society, but also internal, and in this case it will refer to the motivations, feelings and personality of the hero and heroine. Furthermore, as Regis points out, 'through [the barrier] element the writer can examine any situation within the heroine's mind or in the world itself', ${ }^{64}$ and Bertola cleverly makes the most of such an opportunity. Indeed, when Mario learns that Emma is still in love with the man who has just dumped her, his reaction is one of relief: 'Mario respirò sollevato. Tutto andava per il meglio'; ${ }^{65}$ later on, when he tells his cousin and fellow romance reader Ada that he has finally found the 'donna del destino', he triumphally adds: 'È perfetta Ada. C'è anche 1'ostacolo'. 66 To make the situation all the more comic, shortly after Mario falls in love with Emma's friend Camelia, but once again, blinded by his beloved stories, he understands this event as

\footnotetext{
${ }^{63}$ Pamela Regis, A Natural History of the Romance Novel (Philadelphia: University of Pennsylvania Press, 2003). Regis's work offers an accurate analysis of the main tropes of romance novels and how they function in various narrative contexts.

${ }^{64}$ Regis, A Natural History of the Romance Novel, p. 32.

65 Bertola, A neve ferma, p. 105.

${ }^{66}$ Bertola, A neve ferma, p. 125.
} 
an additional barrier in his relationship with Emma, stubbornly reading his situation in terms of the many love triangles he has seen in old romances.

The intertextual framing and the power of parody become more evident when we look at specific tropes of the genre and how they are recast. In the next passage, for example, the fierce and temperamental male protagonist is put under scrutiny when Mario is on his first date with Emma but does not know how to behave, so once again he resorts to his fictional role-models:

Darcy, l'aviatore John o il Conte Hubert, di fronte a una frase così avrebbero inchiodato la Donna Del Destino al più vicino faggio, sussurrandole incoerenti parole d'amore. Mario si sentiva un po' pigro, quella sera, ma comunque baciò Emma. ${ }^{67}$

Here Mario finds himself in a very tricky place: he acknowledges that the situation would require him to act boldly and audaciously, because this is what heroes like Darcy or Rochester would do, but at the same time, he is feeling a bit lazy and eventually settles for an ordinary kiss. The effect is an anticlimax highlighted by the adversative 'ma comunque', which pinpoints the split between the two worlds that Mario inhabits and brilliantly conveys his feeble attempt at living up to his fictional standards.

Likewise, the trope of the love triangle is played throughout the narrative as Camelia and Mario, clearly in love with each other and sharing the same romancemediated fantasies, withhold their passion in the name of the 'barrier' - that is, Emma - until the end of the novel, when the obstacle is removed and the pairing successfully settled. Here Bertola's parody takes a step further, as the removal of the obstacle

${ }^{67}$ Bertola, A neve ferma, p. 105. 
comes in the form of a friendly agreement between Emma and Camelia, which leaves Mario quite baffled:

'Ma io non voglio sposare Camelia. Voglio sposare te.'

'Strano. Sei pazzo di lei.'

'Sì, be', è solo una cosa... cioè, perché tu ami quell'altro, e allora io... si tratta di superare gli ostacoli, in modo che il nostro amore possa... be'... diciamo trionfare. ${ }^{68}$

In the above passage, Mario comically struggles to cope with such an infringement of the genre's main trope, in which the long-suffering lovers eventually triumph over the adversities, without realising that in fact he has been part of it all along, just from a different perspective.

However, the literary sources that Bertola includes, cites and comments on in her novels consist not only of popular romance but also critically acknowledged authors and novels, as previously noted in the case of Mario's literary background. This practice is a common staple of both chick lit and romance, with renowned writers such as William Shakespeare and Jane Austen cited in virtually every novel. In fact, Austen is the most recurrent literary model in popular women's fiction, openly acknowledged as inspirational by almost every writer. This attachment does not come as a surprise: not only is Austen a woman novelist who is fully inscribed in the literary canon, but she also plays an equally significant role in popular culture and fiction, especially in the context of romance and romantic comedies. ${ }^{69}$ In the context of chick lit, Stephanie

\footnotetext{
${ }^{68}$ Bertola, A neve ferma, p. 222.

${ }^{69}$ It is not possible to include here an extensive review of the critical reception and discussion of Austen's works, as well as their presence and role in contemporary fiction. For further information, see for example Claudia L. Johnson, Jane Austen: Women, Politics, and the Novel (Chicago: University of Chicago Press, 1988); Suzanne R. Pucci, and James Thompson, eds., Jane Austen and Co.: Remaking the Past in Contemporary Culture (New York: State University of New York Press, 2003); Cardwell, Sarah, 'Darcy's Escape: An Icon in the Making', in Fashion Cultures: Theories, Explorations, and
} 
Harzewski has highlighted the continuity of Anglo-American chick lit with the tradition of the novel of manners of the nineteenth century, defining the genre 'an ethnographic report on a new dating like the novel of manners, but updated to the climate of feminism' ${ }^{70}$ As such, Harzewski continues, chick lit offers a creative combination of popular and literary forms that helps map contemporary sociocultural behaviours. This view resonates with what, in the context of 'popular literary culture', Jim Collins calls 'Post-Literary Novels': works that seek to negotiate cultural authority and audience participation through a complex web of various intertextual references. ${ }^{71}$

In these books, among which Collins include many chick lit bestsellers, the line between literary tradition and popular culture blurs into a new kind of fiction that shows both 'dismissal of' and 'affiliation with' literary culture. ${ }^{72}$

While this double engagement, so to speak, is carried out by Bertola in countless instances, La soavissima discordia dell'amore offers perhaps the most limpid example of how parody and intertextuality can be used creatively to comment on popular genres, literary canon and cultural authority:

Shakespeare: questo romanzo ne contiene molto, e del resto anche la nostra vita, secondo me, contiene tantissimo Shakespeare, solo che non ci facciamo caso. Parecchio Shakespeare lo troverete dissimulato qua e là nella storia, altro Shakespeare invece è molto evidente, ad esempio il titolo di ogni capitolo è un sonetto del nostro caro William, spesso il primo, ma non sempre. Il numero è quello del sonetto. La cosa migliore che potete fare è leggervi questo romanzo tenendovi vicini i sonetti di S. e andarveli a scartabellare se i versi iniziali vi incuriosiscono. Se non li avete, comprateli

Analysis, ed. by Stella Bruzzi and Pamela Church Gibson (London and New York: Routledge, 2000), pp. 239-44.

${ }^{70}$ Stephanie Harzewski, Chick Lit and Postfeminism (Charlottesville and London: University of Virginia Press, 2011), p. 4.

${ }^{71}$ Jim Collins, Bring on the Books for Everybody: How Literary Culture Became Popular Culture

(Durham: Duke University Press, 2010), p. 187.

${ }^{72}$ Collins, Bring on the Books, p. 191. 
[e] in spiaggia farete un figurone appoggiandoli con noncuranza su uno scoglio o sotto l'ombrellone. ${ }^{73}$

While the above passage reads as a preface, in actual fact Bertola discloses the literary borrowing at the end of the novel, in the final acknowledgements, revealing that the book's main title and those of the chapters are quotes from Shakespeare's sonnets, 'un sonetto del nostro caro William'. To the alert reader, however, this disclosure should not come entirely unexpected, as not only does the structure of the novel evoke the multiple characters and intersecting storylines of Shakespeare's romantic comedies, but also the main plot revolves around an experimental theatre play called 'Shakespeare in cucina', in which actors scream and shout famous Shakespeare quotations while performing dull domestic activities. ${ }^{74}$ The inclusion of a fictional play in the novel indicates Bertola's willingness to tease her readership by using the English playwright and his works as a grid for metafictional and intertextual references of various kinds.

What makes the final acknowledgement truly interesting, however, is once again its tongue-in-cheek tone: Bertola's light-hearted invitation to skim through Shakespeare's sonnets with no strings attached, just out of curiosity ('andateveli a scartabellare se i versi iniziali vi incuriosiscono'), is backed up with a rather amusing encouragement to buy them because they will make you look smarter at the beach. Bertola exploits one of the most common views that equate popular romance fiction with cheap 'summer reading', but if the tone of the comment initially seems to validate the discrepancy

\footnotetext{
${ }^{73}$ Bertola, La soavissima discordia dell'amore, p. 281.

${ }^{74}$ Clearly a parody of postmodern teatro di ricerca, Shakespeare in cucina is indeed presented as a groundbreaking play that will change the way people approach monologues forever: 'Dopo Shakespere in cucina non sarà più possibile ascoltare passivamente l'attore' (Bertola, La soavissima discordia dell'amore, p. 50).
} 
between the sonnets and her own fiction, in reality it challenges ideas of elitist readings and, more specifically, of what women should and should not read. In doing so, Bertola juxtaposes popular and literary readings habits in a process that aims not at elevating women's fiction or dumbing down literary masterpieces, but rather, through parody and intertextuality, at destabilising and reframing their role and meaning in contemporary popular culture. Once again, I believe that this approach is best read in relation to Deleyto's transformative power of the comic perspective in romantic comedies, which in this case creates a space for the negotiation of different and often opposed attitudes toward genre fiction, literary canon and cultural authority.

\subsection{Conclusions}

I have analysed Bertola's romantic comedies as the terrain for the recognition, celebration and disruption of the main themes and tropes of chick lit and popular romance through humour and intertextuality. In particular, I have discussed how generic tropes and narrative techniques come together to provide a subtext for variations of style and language, which Bertola handles with refreshing and skilful inventiveness. Imelda Whelehan has noted that while chick lit does not provide a critique of the idealisation of romantic love that permeates conventional romance, it does not celebrate it either; rather, it aims at reading topics such as femininity, monogamy and heterosexuality through the lens of 'observational humour'. ${ }^{75}$ Following a similar line of thought, Deleyto's work on cinematic romantic comedies has emphasised humour as the 'main engine of narrative development and the mirror

${ }^{75}$ Imelda Whelehan, The Feminist Bestseller: From Sex and the Single Girl to Sex and the City (New York: Palgrave Macmillan, 2005), pp. 186-87. 
through which the texts look at society', ${ }^{76}$ specifically in the context of affective and intimate relationships. In other words, both scholars highlight the pivotal role of humour in framing and addressing the variety and complexity of sentimental matters in contemporary society, an approach that is well on display in Bertola's fiction. Indeed, her use of intertextuality aims at challenging the conventions of a genre that, in Italy, tends to resist not only humour, but also any variation in style. As such, Bertola's intertextual framework is significant because it is one of playful, self-critical reflexivity.

Taking the lead from Rose's work on parody, I have shown how Bertola's familiarity with and understanding of the salient conventions of genre fiction helps her to make the most of parody's double purpose, that is, of contempt and sympathy. ${ }^{77}$ While she maintains all the main tropes and conventions of chick lit and romance, she also deconstructs or exposes them in a way that prompts multiple levels of engagement. In this context, it might be argued that, despite the parodic and intertextual efforts at work, these novels are ultimately nothing more than amusing 'beach readings', as Bertola herself has suggested, thus to be confined to marginal spaces in the literary scene. Yet, I believe that it is exactly such management of generic characters, tropes and storylines that encourages the critical discussion of Bertola's novels within the genre, pointing to a more comprehensive reading of the variety and complexity of popular romance fiction.

\footnotetext{
${ }^{76}$ Deleyto, 'Rewind: Desire and the Arabesque of Plot in Romantic Comedy', in Generic Attractions: New Essays on Film Genre Criticism, ed. by Maria del Mar Azcona and Celestino Deleyto (Paris: M. Houdiard, 2010), pp. 105-115 (p. 108).

${ }^{77}$ Rose, Parody / Meta-fiction, pp. 28-30.
} 


\section{CONCLUSION}

In Chick Lit: The New Woman's Fiction (2006), the first comprehensive scholarly study of chick lit, Suzanne Ferriss and Mallory Young point out the novelty factor that the genre brought into the cultural and literary landscape of the mid-1990s worldwide. On the one hand, chick lit was a decidedly new kind of women's popular fiction, whose formal and stylistic features presented innovative elements such as the humorous tone used to negotiate sentimental relationships; on the other hand, these novels were explicitly 'about and for' a new type of woman - middle-class, white, heterosexual and financially independent - caught in intricate discourses of consumerism, sexuality, race and class at the turn of the century. ${ }^{1}$ Some years later, the debate among scholars on the qualities and shortcomings of chick lit confirms that the genre is an intriguing subject of analysis, one that has been discussed equally as a marketing ploy, a 'post-literary' and 'post-romantic' cultural product, a genuine attempt at addressing the experiences and issues of contemporary women in Western countries, and a commentary on feminism and its place in today's society.

In this thesis I have explored the way in which a growing body of Italian writers has addressed this rich and controversial genre in the last few years, examining a significant sample of chick lit written in Italian from the early 2000s on. My analysis has been both descriptive and interdisciplinary: by means of a close textual reading, I have attempted to define the social, cultural and literary place occupied by chick lit among Italy's contemporary popular fiction. I have also focused on the way the

${ }^{1}$ Suzanne Ferriss and Mallory Young, Chick Lit. The New Woman's Fiction. (New York: Routledge, 2006), p. 12. 
genre's recurring themes, narrative structure and stylistic features have been articulated in the Italian novels, not only against the Anglo-American models, but also in relation to popular media culture and the Italian tradition of romanzo rosa. In doing so, I have initiated a much-needed discussion on women's popular fiction, a field largely neglected in Italy's literary studies for a number of reasons, such as the genre's unchallenging formal features and its overtly escapist nature, but above all for being a distinctively 'feminine' genre. In fact, if mass-oriented and commercially successful genres have generally been greeted with condescension by Italian critics, who at various stages have questioned their literary value, in the case of women's popular fiction the tones have been all the more dismissive precisely because of its subject matter, with layers of gendered misconceptions that downgrade the texts, the writers and the audience alike. ${ }^{2}$

By contrast, I have drawn attention to the variety and complexity of these narratives and their most recent development in contemporary Italy through three perspectives: as the local replica of a commercial phenomenon in women's popular culture; as the fictional mirror of women in contemporary Italy; and as an intertextual dialogue with the literary tradition of romanzo rosa. In this regard, Anne Cranny-Francis's definition of popular cultural texts as 'active potentials, ${ }^{3}$ has been instrumental to my analysis: against the widely held notion of popular genres as the product of dominant ideologies that are passively consumed by audiences, Cranny-Francis maintains that popular culture products are in fact constantly evaluated and interpreted through a dynamic process where different people perform different readings and thus generate diverse

\footnotetext{
${ }^{2}$ See Antonia Arslan, and Maria Pia Pozzato, 'Il rosa', in Letteratura Italiana, Storia e geografia, III, ed. by Alberto Asor Rosa (Turin: Einaudi, 1989), pp. 1027-46 (p. 1027).

${ }^{3}$ Anne Cranny-Francis, Popular Culture (Geelong: Deakin University Press, 1994), p. 1.
} 
and often opposite meanings. Here Cranny-Francis's confirms the findings of Tania Modleski’s Loving with a Vengeance: Mass-Produced Fantasies for Women, which examined mass-produced texts aimed at women such as Gothic paperbacks, Harlequin romances and soap operas. In her groundbreaking study, one of the first to put popular genres directed at female audiences under close scrutiny, Modleski rightly observed that 'while appearing to be merely escapist, such art simultaneously challenges and reaffirms traditional values, behaviour and attitudes', ${ }^{4}$ arguing that these texts must not be dismissed as unproblematic mass-market products but rather investigated as sites of ideological tensions and competing discourses.

In my analysis of Italian chick lit novels I have highlighted some of those competing discourses and assessed how Italian writers deploy not only the narrative tropes, but also the cultural trends set up by Anglophone chick lit. What emerges is the presence of distinctive, 'glocal' patterns in regard to key generic features, such as the identification with the female protagonist and her journey toward self-empowerment, the relationship with consumer culture and the humorous style. All of the Italian texts show themselves to be at ease with the first two elements, each in their own way effectively integrating them. Lisa Corva's Glam cheap borrows chick lit staples such as the obsession with designer clothes and consumer culture to write about issues that are such as lavoro precario and job flexibility from a local perspective; likewise, the successful 'trilogia di Monica' written by the queen of Italian chick lit, Federica Bosco, is a tale of self-empowerment that follows the social and personal development of the main character Monica, an Italian single thirtysomething living in New York.

${ }^{4}$ Tania Modleski, Loving with a Vengeance: Mass-Produced Fantasies for Women (Hamden: Archon, 1982), p. 112. 
By contrast, the analysis of chick lit's humorous tone has proven to be more challenging. Intrigued by the comic banter that permeates the Anglophone texts, I hoped that the Italian writers would make the most of the comedic vein of the original models and translate it into their texts, finally bringing a breath of fresh air into the melodramatic seriousness that is romanzo rosa's most enduring legacy. However, with the notable exception of Stefania Bertola, to various degrees Italian writers struggle to fully integrate chick lit's humour into their works. If parody and intertextuality are the backbone of Bertola's romantic comedies, allowing her to re-interpret chick lit and romanzo rosa tropes through a crafted blend of narrative codes and conventions, other writers' humorous solutions are overall limited to occasional slapstick gags or predictable self-deprecating jokes. My contention is that such overt difficulty in managing a truly humorous tone signals these writers' anxiousness to distance their writing from the alleged frivolity of Anglo-American chick lit and, by the same token, their desire to gain respectability on the Italian literary stage. Indeed, Joanne Knowles has pointed out how despite featuring more realistic elements with regard to women's issues and expectations, particularly when compared to the mass-market romance, critics still frown upon chick lit because of its trivial approach to these issues, showing a conservative form of criticism that encompasses form and genre altogether. ${ }^{5}$

Given the condescension of Italy's literary establishment toward women's popular fiction, the recurring claim of seriousness and realism made by virtually every Italian chick lit writer in regard to their take on the genre does not come as a surprise. As we have seen, in each and every interview they all stress that, while their books may be

\footnotetext{
5 Joanne Knowles, “'Our foes are almost as many as our readers": Debating the Worth of Women's Reading and Writing - The Case of Chick-lit', Popular Narrative Media, 1 (2008), 217-31 (p. 226).
} 
marketed as chick lit, they do not really belong to the genre. It seems that 'chick lit' comes as a ready-made commercial label that they are happy to wear as long as it brings visibility in the marketplace, only to discard it the moment such visibility is achieved. Even those who do embrace the genre claim to be different and culturally superior to their Anglophone counterparts, either because of their more nuanced writing, or because of the subject matter of their stories. Virginia Fiume, co-author of Voglio un mondo rosa shokking, makes this concern quite clear when she states that the chick lit format has been used just as a practical disguise in order to make important topics more accessible: 'noi abbiamo voluto [...] usare un linguaggio semplice e immediato per parlare di argomenti "seri”". 6

It is in the relationship with the American TV show Sex and the City - one of chick lit's cornerstones worldwide and the key cultural reference for the genre in Italy where such preoccupations are perhaps best addressed. The inclusion of the TV show's characters and their glamorous, liberated and assertive lifestyle is a recurring trope in all novels, one which the protagonists initially regard as their guiding light but gradually downplay and eventually reject because it fails to reflect the real issues that women face in real life. However, it is perhaps more interesting to note how, parallel to this ideological reassessment, significant formal and stylistic adjustments take place as well. Almost every writer gradually moves from droll to downright didactic tones, overlooking the comedic and potentially subversive mode of chick lit and reverting to a self-imposed discursive hierarchy in which serious matters must not be ridiculed or handled humorously. In many ways, this is the most disappointing (if not counter-

\footnotetext{
6 'Intervista a Virginia Fiume \# 1. Il suo libro, le donne, il lavoro e molto altro' Bizbiz, 19 December $2007<$ http://thebizbiz. blogspot.com/2007/12/intervista-virginia-fiume-1-il-suo.html> [accessed 12 January 2010].
} 
productive) element in Italian chick lit, which ultimately fails to integrate the genre's most innovative trait and confirms that romanzo rosa's codes, values and practices are still woven into the very fabric of Italian popular fiction aimed at women.

Thought-provoking as it has been, my journey into the multifaceted world of chick lit is a partial one and thus opens up possibilities for further investigation. I have addressed the genre's relationship with postfeminism and the 'postfeminist sensibility ${ }^{7}$ that pervades today's women's popular media culture, where feminist and anti-feminist ideologies are embraced and challenged, and conservative neoliberal ideas are being promoted through appealing yet controversial terms such as selfdetermination and freedom of choice. ${ }^{8}$ As a postfeminist sensibility clearly surfaces in home-grown chick lit, with recurring discourses of assertiveness, choice and selfempowerment, the genre offers valuable materials for the study of postfeminism in Italy's popular and media culture - a topic that has received little to no attention so far.

Similarly, I have touched upon gender representations in Italian chick lit, an area of research that needs to be addressed further. While ageing women feature prominently, both as protagonists and secondary characters, queer identities receive little attention and remain confined to minor characters and stereotypical features, encouraging the analysis of the way Italian novels represent and comment on issues of age and sexuality across genders. Moreover, since an increasing flow of immigrants is rapidly changing Italy's sociocultural fabric, the absence of women of colour in domestic chick lit raises questions on how, if at all, the country's new multiculturalism will be reflected in the

\footnotetext{
${ }^{7}$ Rosalind Gill, 'Postfeminist Media Culture: Elements of a Sensibility', European Journal of Cultural Studies, 10, 2 (2007), 147-66.

${ }^{8}$ See Gill, 'Postfeminist Media Culture', pp. 148-49; Angela McRobbie, 'Post-Feminism and Popular Culture', Feminist Media Studies, 4 (2004), 255-64.
} 
genre as well: as some of the new directions in Anglophone chick lit suggest, themes such as immigration and race add layers that complicate the genre's features.

A further element of discussion comes from a growing body of male writers who have recently gained considerable success in the marketplace, such as Fabio Volo (b. 1972) and Luca Bianchini (b. 1970) to name but two. Written in the first person, their novels read the affective, emotional and professional anxieties of white, middle-class, heterosexual men through the lens of humour and comedy, following a trend started in the Anglophone market by Nick Hornby and Matt Dunn and dubbed, not surprisingly, 'lad lit'. ${ }^{9}$ Alongside the works of Federica Bosco, Stefania Bertola and all the writers I have examined, these novels constitute the ideal basis for a thorough exploration of sentimental relationships and emerging models of femininity and masculinity in contemporary Italy's popular culture.

Finally, all the different 'shades of pink' presented in this thesis paint a picture of a lively and diversified field, and point to the need for collaborative research among scholars from various disciplines in order to explore the links that these texts maintain with popular cultural media other than fiction, such as magazines, films and TV shows. Looking at the many ways they combine and blend with each other, more and more fascinating shades emerge, showing that women's popular culture is a rich palette that still offers much to scholars, in Italy and internationally.

\footnotetext{
${ }^{9}$ Daniela De Rosa, 'Chick Lit, Lad Lit, Click Lit', in Tirature 05, ed. by Vittorio Spinazzola (Milan: Gruppo editoriale il Saggiatore/Fondazione Mondadori, 2005), pp. 70-74; Rosalind Gill, 'Lad Lit as Mediated Intimacy: A Postfeminist Tale of Female Power, Male Vulnerability and Toast', Working Papers on the Web, 13 (2009) <http://extra.shu.ac.uk/wpw/chicklit/gill.html> [accessed 15 December 2009].
} 


\section{BIBLIOGRAPHY}

Ahuvia, Aaron C., 'Beyond Extended Self: Loved Objects and Consumers' Identity Narratives', Journal of Consumer Research, 32 (2005), 171-84

Akass, Kim, and Janet McCabe, eds, Reading Sex and the City (London and New York: I.B. Tauris, 2006)

Altman, Rick, 'A Semantic/Syntactic Approach to Film Genre', Cinema Journal, 23 (1984), 6-18

—

Amendola, Alfonso, ed., È tutto Sex and the City: Moda, metropoli, amicizia e seduzione in una fiction televisiva (Napoli: Liguori, 2011)

Annesley, James, Fictions of Globalization (London, New York: Continuum, 2006)

Appadurai, Arjun, Modernity at Large: Cultural Dimensions of Globalization (Minneapolis: University of Minnesota Press, 1996)

Aricò, Santo L., Contemporary Women Writers in Italy (Amherst: The University of Massachusetts Press, 1990)

Arpanet, 'ChickCult', <http://www.chickcult.it/ilgenerechickcult.asp> [accessed 10 March 2010].

Arslan, Antonia, Dame, droga e galline: Romanzo popolare e romanzo di consumo tra '800 e '900 (Padua: CLEUP, 1977)

_- Dame, galline e regine: La scrittura femminile italiana fra '800 e '900 (Milan: Guerini studio, 1998)

— , and Maria Pia Pozzato, 'Il rosa', in Letteratura italiana. Storia e geografia, III, ed. by Alberto Asor Rosa (Turin: Einaudi, 1989), pp. 1027-46

Arthurs, Jane, 'Sex and the City and Consumer Culture: Remediating Postfeminist Drama', Feminist Media Studies, 3 (2003), 83-98 
Arviddson, Adam, Marketing Modernity: Italian Advertising from Fascism to Postmodernity (London: Routledge, 2003)

Azcona, María del Mar, and Celestino Deleyto, eds, Generic Attractions: New Essays on Film Genre Criticism (Paris: M. Houdiard, 2010)

Baccolini, Raffaella, ed., Le prospettive di genere: Discipline, soglie e confini (Bologna: Bononia University Press, 2005)

Balducci, Federica, 'Sulle ali littorie: La biblioteca A. Ponti di Imola (1922-1940)' (unpublished Tesi di Laurea, Bologna: Università degli Studi di Bologna, 1998)

__ , 'Leggere al femminile: La biblioteca “A. Ponti” di Imola tra 1935 e 1940', Il Carrobbio: Rivista di studi bolognesi, 25 (1999), 267-76

Ballestra, Silvia, 'Gasperini, e il rosa diventò "lessico famigliare"', Il Corriere della Sera, 02 August 2000, p. 27 <http://archiviostorico.corriere.it/2000/agosto/02/ Gasperini_rosa_divento_lessico_famigliare_co_0_0008021663.shtml> [accessed 16 June 2010]

Bamzai, Kaveree, 'The Indian Ms Jones', India Today, 21 January 2008, p. 89

Banti, Anna, 'Storia e ragioni del romanzo rosa', in Opinioni (Milan: il Saggiatore, 1961), pp. 75-82

Bazardi, Alessandra, 'Accoppiate o single, è una questione di stile', Giornale della Libreria, 119 (2006), 44

Beer, Gillian, The Romance (London: Methuen, 1970)

Beirne, Rebecca, Lesbians in Television and Text After the Millennium (New York: Palgrave Macmillan, 2008)

Bertola, Stefania, Ne parliamo a cena (Milan: Salani, 1999)

__, Aspirapolvere di stelle (Milan: Salani, 2002)

—, Biscotti e sospetti (Milan: Salani, 2004)

__, 'Che ossessione lo spot', La Stampa Tuttolibri, 20 November 2004, p. 7 
_- A neve ferma (Milan: Salani, 2006)

__, La soavissima discordia dell'amore (Milan: Salani, 2009)

Bethman, Brenda, ““Chick-Lit” Revisited: Bridget Jones Meets Jessica, 30', 2005 <http://www.womeningerman.org/conference/2005/epanel/bethmanwig2005 synopsis.pdf $>$ [accessed 19 May 2008]

Betri, Maria Luisa, Leggere, obbedire, combattere: le biblioteche popolari durante il fascismo (Milan: Franco Angeli, 1991)

Bini, Benedetta, 'Il poliziesco', in Letteratura italiana. Storia e geografia, III, ed. by Alberto Asor Rosa (Turin: Einaudi, 1989), pp. 999-1026

Blank, Hanne, 'Don't Hate Me Because I'm Cute', Baltimore City Paper, 10 September 2003, <http://www.citypaper.com/special/story.asp?id=5973> [accessed 10 February 2008]

Bloom, Clive, Cult Fiction (London, New York: Macmillan, 1996)

Booth, Marilyn, "'The Muslim Woman" as Celebrity Author and the Politics of Translating Arabic: Girls of Riyadh Go On The Road', Journal of Middle East Women's Studies, 6 (2010), 149-82 <http://muse.jhu.edu/journals/journal_of_ middle_east_womens_studies/v006/6.3.booth.html> [accessed 12 January 2011].

Bordoni, Carlo, Cultura e propaganda dell'Italia fascista (Messina-Firenze: D’Anna, 1974)

__, Il romanzo senza qualità: Sociologia del nuovo rosa (Neaples: Libreria sapere, 1984)

__ Il romanzo di consumo: Editoria e letteratura di massa (Neaples: Liguori, 1993)

Borgatti, Simona, 'Vi presento Lisa Corva, già "giornalista finto glam", 2009 $<$ http://www.tellusfolio.it/index.php?prec=/index.php\&cmd=v\&lev=44\&id=65 30> [accessed 27 January 2010]

Bosco, Federica, Mi piaci da morire (Rome: Newton Compton, 2005)

— L L'amore non fa per me (Rome: Newton Compton, 2007)

— L L'amore mi perseguita (Rome: Newton Compton, 2008)

_- Innamorata di un angelo (Rome: Newton Compton, 2011) 
Bourdieu, Pierre, The Field of Cultural Production (Cambridge: Polity Press, 1993)

—, Distinction: A Social Critique of the Judgement of Taste (London: Routledge, 1984)

Bouricius, Ann, The Romance Readers' Advisory: The Librarian's Guide to Love in the Stacks (Chicago and London: The American Library Association, 2000)

Braithwaite, Ann, 'The Personal, the Political, Third-wave and Postfeminisms', Feminist Theory, 3 (2002), 335-44

Brodesco, Alberto, 'Harmony: L'amore in edicola', in Luigi Del Grosso Destrieri, and others, Una galassia rosa: Ricerche sulla letteratura femminile di consumo (Milan: Franco Angeli, 2009), pp. 37-83

Brooks, Ann, Postfeminisms: Feminism, Cultural Theory, and Cultural Forms (London and New York: Routledge, 1997)

Bruzzi, Stella, and Pamela Church Gibson, 'Fashion Is the Fifth Character: Fashion, Costume and Character in Sex and the City', in Reading Sex and the City, ed. by Kim Akass and Janet McCabe (London and New York: I.B. Tauris, 2006), pp. 115-29

—- eds, Fashion Cultures: Theories, Explorations, and Analysis (London and New York: Routledge, 2000), pp. 239-44

Burgin, Victor, James Donald, and Cora Kaplan, eds, Formations of Fantasy (London and New York: Methuen, 1986)

Busato, David, 'Intervista a Federica Bosco', EuropaSera, 5 October 2007 $<$ http://www.europasera.it/vedi.php?cat=interviste\&id=71> [accessed 27 May 2010]

Bushnell, Candace, Sex and the City (New York: Warner Books, c1996; New York: Grand Central Publishing, 2006)

Butler, Pamela, and Jigna Desai, 'Manolos, Marriage, and Mantras: Chick Lit Criticism and Transnational Feminism', Meridians: Feminism, Race, Transnationalism, 8 (2008), 1-31 
Cabot, Heather, “'Chick Lit” Fuels Publishing Industry', ABCnews.com, 30 August 2003 <http://abcnews.go.com/WNT/story?id=129475\&page=1> [accessed 28 January 2008]

Campani, Giovanna, Veline, nyokke e cilici: Femministe pentite senza sex e senza city (Bologna: Odoya, 2009)

Canevari, Rossella, and Virginia Fiume, Voglio un mondo rosa shokking (Rome: Newton Compton, 2007)

Cannistraro, Philip V., La fabbrica del consenso: Fascismo e mass-media (Rome-Bari: Laterza, 1975)

Cardwell, Sarah, 'Darcy's Escape: An Icon in the Making', in Fashion Cultures: Theories, Explorations, and Analysis, ed. by Stella Bruzzi and Pamela Church Gibson (London and New York: Routledge, 2000), pp. 239-44

Casella, Alessandra, Un anno di Gloria (Milan: Salani, 2001)

Cassamagnaghi, Silvia, Immagini dall'America: Mass media e modelli femminili nell'Italia del secondo dopoguerra 1945-1960 (Milan: Franco Angeli, 2007)

Cawelti, John G., Adventure, Mystery, and Romance: Formula Stories as Art and Popular Culture (Chicago: University of Chicago Press, 1976)

Centro di documentazione ricerca e iniziativa delle donne, ed., Intorno al rosa (Verona: Essedue, 1987)

Ceserani, Remo, and Elena Salibra, 'Popular Literature in Nineteenth-Century Italy: Letteratura amena', Canadian Review of Comparative Literature, 9 (1982), 361-82

Chan, Joseph M., and Bryce T. McIntyre, eds, In Search of Boundaries: Communication, Nation-State and Cultural Identities (Westport: Ablex, 2002)

Chen, Eva Yin-I, 'Shanghai Baby as a Chinese Chick-Lit: Female Empowerment and Neoliberal Consumerist Agency', Asian Journal of Women's Studies, 15 (2009), 54-93 <http://dcollection.ewha.ac.kr/jsp/common/DcLoOrgPer.jsp?sItemId $=000000052713>$ [accessed 23 January 2010] 
'Chick Lit', Working Papers on the Web, 13 (2009) <http://extra.shu.ac.uk/ wpw/chicklit/ index.html> [accessed 15 December 2009]

Ciasullo, Ann M., 'Making Her (In)Visible: Cultural Representations of Lesbianism and the Lesbian Body in the 1990s', Feminist Studies, 27 (2001), 577-608

Cole, Allison, 'Can't Afford the Manolos? Buy the Book! Chick Lit \& Contemporary Consumerism', Undergraduate Research Symposium, 2007 <http://digitalcommons.colby.edu/ugrs/13> [accessed 04 February 2011]

Collins, Jim, Bring on the Books for Everybody: How Literary Culture Became Popular Culture (Durham: Duke University Press, 2010)

Cooke, Maureen Lynch, 'The Great Escape: Modern Women and the Chick Lit Genre' (unpublished Master's thesis, Boston College, 2006)

Cooper-Chen, Anne, ed., Global Entertainment Media: Content, Audiences, Issues (Mahwah, N.J.: L. Erlbaum, 2005)

Corbi, Maria, 'Piccole pollastre leggono', La Stampa, 02 September 2003, p. 23

Covito, Carmen, La bruttina stagionata (Milan: Bompiani, 1992)

Corva, Lisa, Glam cheap (Milan: Sonzogno, 2007)

Craddock, Louise, 'Bridget Jones's Little Red Dress: Chick Lit, Mass-Market Popular Romance and Feminism', Diegesis, 8 (2004), 42-50

Crainz, Guido, Storia del miracolo italiano: Culture, identità, trasformazioni fra anni Cinquanta e Sessanta (Rome: Donizelli, 2003)

Cranny-Francis, Anne, Popular Culture (Geelong: Deakin University Press, 1994)

Danford, Natalie, 'The Chick Lit Question', Publishers Weekly, 20 October 2003, p. 3

Davis-Kahl, Stephanie, 'The Case for Chick Lit in Academic Libraries', Collection Building, 27 (2008), 18-21 
De Donato, Gigliola, and Vanna Gazzola Stacchini, eds, I best seller del ventennio: Il regime e il libro di massa (Rome: Editori Riuniti, 1991)

de Lauretis, Teresa, Alice Doesn't: Feminism, Semiotics, Cinema (Bloomington: Indiana University Press, 1984)

Deleyto, Celestino, 'Between Friends: Love and Friendship in Contemporary Hollywood Romantic Comedy', Screen, 44 (2003), 167-82 <doi:10.1093/screen/44.2.167>

— The Secret Life of Romantic Comedy (Manchester: Manchester University Press, 2009)

_- 'Rewind: Desire and the Arabesque of Plot in Romantic Comedy', in Generic Attractions: New Essays on Film Genre Criticism, ed. by Maria del Mar Azcona and Celestino Deleyto (Paris: M. Houdiard, 2010), pp. 105-15

Dellantonio, Marco, 'Intervista a Camilla Vittorini', lettera.com, 11 December 2004 $<$ http://www.lettera.com/articolo.do?id=12803> [accessed 05 March 2008]

De Luca, Maria Novella, 'Passioni e intrighi senza lieto fine così cambia il romanzo per single', La Repubblica, 21 February 2002, p. $30<\mathrm{http}: / /$ ricerca.repubblica.it/ repubblica/archivio/repubblica/2002/02/21/passioni-intrighi-senza-lieto-fine-co si-cambia.html> [accessed 08 November 2009].

Del Grosso Destrieri, Luigi, and others, Una galassia rosa: Ricerche sulla letteratura femminile di consumo (Milan: Franco Angeli, 2009)

De Rosa, Daniela, 'Chick Lit, Lad Lit, Click Lit', in Tirature 05, ed. by Vittorio Spinazzola (Milan: Gruppo editoriale il Saggiatore/Fondazione Mondadori, 2005), pp. 70-74

Detti, Ermanno, Le carte rosa: storia del fotoromanzo e della narrativa popolare (Florence: La Nuova Italia, 1990)

DiNardo, Kelly, 'Chick lit menu goes beyond standard fare', USA TODAY, 21 April 2004, <http://www.usatoday.com/life/books/reviews/2004-04-21 -chick-lit_x.htm> [accessed 05 March 2008]

Djundjung, Jenny Mochtar, 'The Construction of Urban Single Career Woman in Indonesian Chick Lit, Jodoh Monica', K@ ta, 6 (2004), 106-23 
<http://203.189.120.190/ejournal/index.php/ing/article/shop/16263/16255> [accessed 05 March 2008]

—- 'Beautiful Body and Femininity in Five British and Indonesian Chick Lit' (Surabaya: Petra Christian University, 2007) <http://fportfolio.petra.ac.id/ user_files/86-012/Beautiful\%20Body\%20and\%20Feminity.doc > [accessed 28 February 2011]

Donadio, Rachel, 'The Chick Lit Pandemic', The New York Times, 19 March 2006, p. 31 <http://www.nytimes.com/2006/03/19/books/review/19donadio.html> [accessed 05 January 2008]

Dreisinger, Baz, 'The Queen in Shining Armor', Journal of Popular Film \& Television, 28 (2000), 2-11

Duff, David, Modern Genre Theory (Harlow, New York: Longman-Pearson Education, 2000)

Eagleton, Mary, 'Genre and Gender', in Modern Genre Theory, ed. by David Duff (Edinburgh: Longman, 2000), pp. 250-62

Ebert, Teresa L., The Task of Cultural Critique (Urbana: University of Illinois Press, 2009)

Eco, Umberto, and others, Invernizio, Serao, Liala (Florence: La Nuova Italia, 1979)

—, 'Tre donne intorno al cor...', in Umberto Eco, and others, Invernizio, Serao, Liala (Florence: La Nuova Italia, 1979), pp. 3-27

_- 'Innovation \& Repetition: Between Modern \& Postmodern Aesthetics', Daedalus, 134 (2010), 191-207

— - Postscript to The Name of the Rose (San Diego: Harcourt Brace Jovanovich, 1984)

Evans, Peter William, and Celestino Deleyto, eds, Terms of Endearment: Hollywood Romantic Comedy of the 1980s and 1990s (Edinburgh: Edinburgh University Press, 1998)

Ezard, John, 'Bainbridge tilts at "chick lit” cult', The Guardian, 24 August 2001, <http://www.guardian.co.uk/uk/2001/aug/24/books.generalfiction> [accessed 05 January 2008] 
Faludi, Susan, Backlash: The Undeclared War Against American Women (New York: Crown, 1991)

Fantone, Laura, 'Precarious Changes: Gender and generational politics in contemporary Italy', Feminst Review, 87 (2007), 5-20

Featherstone, Mike, Scott Lash, and Roland Robertson, eds, Global Modernities (London: Sage, 1995)

Federzoni, Marina, 'Carolina Invernizio', in Umberto Eco, and others, Invernizio, Serao, Liala (Florence: La Nuova Italia, 1979), pp. 29-59

Feral, Anne-Lise Louise Josiane, Genre and Gender in Translation: The Poetological and Ideological Rewriting of Heroine-Centred and Women-Oriented Fiction (unpublished $\mathrm{PhD}$ thesis, University of Edinburgh, 2009)

Ferriss, Suzanne, and Mallory Young, eds, Chick Lit: The New Woman's Fiction. (New York: Routledge, 2006)

—_, 'Chicks, Girls and Choice: Redefining Feminism', Junctures, 6 (2006), 87-97

—- eds, Chick Flicks: Contemporary Women at the Movies (New York: Routledge, 2007)

Ferroni, Giulio, and others, Sul banco dei cattivi: A proposito di Baricco e di altri scrittori alla moda (Rome: Donizelli, 2006)

Fiddler, Allyson, 'Of Political Intentions and Trivial Conventions: Erika Pluhar's Die Wahl (2003) and Marlene Streeuwitz's Jessica, 30. (2004)', German Life and Letters, 64 (2011), 133-44 <doi: 10.1111/j.1468-0483.2010.01525.x> [accessed 11 January 2011]

Fielding, Helen, Bridget Jones's Diary (London: Picador, 1996)

Fisher, Sue, and Kathy Davis, eds, Negotiating at the Margins (New Brunswick: Rutgers University Press, 1993)

Fiske, John, Television Culture (London New York: Routledge, 1987)

_ Reading the Popular (London and New York: Routledge, 1989) 
—_ 'The Cultural Economy of Fandom', in The Adoring Audience: Fan Culture and Popular Media, ed. by Lisa A. Lewis (London and New York: Routledge, 1992), pp. 30-49

Forgacs, David, 'Paninari', in Italian Cultural Studies: An Introduction, ed. by David Forgacs and Robert Lumley (New York: Oxford University Press, 1996), pp. $344-46$

—_ and Robert Lumley, eds, Italian Cultural Studies: An Introduction (New York: Oxford University Press, 1996)

Forte, Gioacchino, I persuasori rosa (Naples: ESI, 1966)

Fowler, Alastair, Kinds of Literature: An Introduction to the Theory of Genres and Modes (Cambridge: Harvard University Press, 1982)

Frati, David, 'Intervista a Rossella Canevari', Mangialibri $<\mathrm{http} / / /$ mangialibri.com/?q=node/3215> [accessed 16 November 2010]

Friedman, Monroe, A “Brand” New Language (Westport: Greenwood Press, 1991)

Frow, John, Genre (London and New York: Routledge, c2005, 2006)

Gamble, Sarah, 'Postfeminism', in The Routledge Companion to Feminism and Postfeminism, ed. by Sarah Gamble (London: Routledge, 2001), pp. 43-53

_ - 'When Romantic Heroines Turn Bad: The Rise of the 'Anti-Chicklit' Novel', Working Papers on the Web, 13 (2009) <http://extra.shu.ac.uk/wpw/ chicklit/gamble.html > [accessed 15 December 2009]

Gelder, Ken, Popular Fiction: The Logics and Practices of a Literary Field (London and New York: Routledge, 2004)

Genette, Gérard, Figures of Literary Discourse (Oxford: Basil Blackwell Publisher, 1982)

_- Paratexts. Thresholds of Interpretation (Cambridge: Cambridge University Press, 1987)

—_, 'Introduction to Paratext', New Literay History, 22 (1991), 261-72

_- 'Structure and Functions of the Title in Literature', Critical Inquiry, 14 (2008), $692-720$ 
Genz, Stéphanie, 'Third Way/ve: The Politics of Postfeminism', Feminist Theory, 7 (2006), 333-53

_- Postfemininities in Popular Culture (New York: Palgrave Macmillan, 2009)

_- 'Singled Out: Postfeminism's "New Woman" and the Dilemma of Having It All', The Journal of Popular Culture, 43 (2010), 97-119

Ghiazza, Silvana, 'Così donna mi piaci. La letteratura rosa negli anni venti-quaranta', in I best seller del ventennio: Il regime e il libro di massa, ed. by Gigliola De Donato and Vanna Gazzola Stacchini (Rome: Editori Riuniti, 1991), pp. $129-277$

Gill, Jo, ed., Modern Confessional Writing: New Critical Essays (New York: Routledge, 2006), pp. 84-99

Gill, Rosalind, Gender and the Media (Cambridge, Malden: Polity Press, 2007)

_- 'Postfeminist Media Culture: Elements of a Sensibility', European Journal of Cultural Studies, 10 (2007), 147-66

__, 'Postfeminist Romance', in Gender and the Media (Cambridge, Malden: Polity Press, 2007), pp. 218-48

__ , and Jane Arthurs, 'New Femininities?', Feminist Media Studies, 6 (2006), 443

— Lit?', Feminist Media Studies, 6 (2006), 487-504

— , 'Lad Lit as Mediated Intimacy: A Postfeminist Tale of Female Power, Male Vulnerability and Toast', Working Papers on the Web, 13 (2009) <http://extra.shu.ac.uk/wpw/chicklit/gill.html> [accessed 15 December 2009]

— Cultural Work', Theory, Culture \& Society, 25 (2008), 1-30 <doi: 10.1177/0263276408097794> [accessed 19 May 2010]

Gillis, Stacy, Gillian Howie, and Rebecca Munford, Third Wave Feminism: A Critical Exploration (Basingstoke: Palgrave Macmillan, 2004)

Giovanetti, Silvia, 'Chick-lit: una letteratura "rosa shopping", in Luigi Del Grosso Destrieri, and others, Una galassia rosa: Ricerche sulla letteratura femminile di consumo (Milan: Franco Angeli, 2009), pp. 85-136 
Giugni, Marco, ed., The Politics of Unemployment in Europe: Policy Responses and Collective Action (Farnham and Burlington: Ashgate, 2009)

Goldman, Robert, Deborah Heath, and Sharon L. Smith, 'Commodity Feminism', Critical Studies in Mass Communication, 8 (1991), 333-51 <doi: 10.1080/15295039109366801> [accessed 07 September 2009]

Goodman, Diane, 'What Is Chick lit?', Electronic Book Review, 01 September 1996 <http://www.electronicbookreview.com/thread/writingpostfeminism/gutsy> [accessed 28 January 2008]

Goren, Lilly J., ed., You've Come a Long Way, Baby: Women, Politics, and Popular Culture (University Press of Kentucky, 2009)

Gormley, Sarah, 'Introduction', Working Papers on the Web, 13 (2009) $<$ http://extra.shu.ac.uk/wpw/chicklit/gormley.html> [accessed 15 December 2009]

Grandi, Daniela, Il club dei pettegolezzi (Rome: Newton Compton, 2009)

Guenther, Leah, 'Bridget Jones's Diary: Confessing Post-Feminism', in Modern Confessional Writing: New Critical Essays, ed. by Jo Gill (New York: Routledge, 2006), pp. 84-99

Hale, Elizabeth, 'Long-Suffering Professional Females: The Case of Nanny Lit', in Chick Lit: The New Woman's Fiction, ed. by Suzanne Ferriss and Mallory Young (New York: Routledge, 2006), pp. 103-18

Harlequin Enterprises Limited, 'A Global Success Story' <http://www.eharlequin.com/store.html?cid=2659> [accessed 1 March 2011]

—_, 'Writing Guidelines - Chick Lit', <http://www.eharlequin.com/ articlepage.html?articleId=558\&chapter=0> [accessed 28 January 2008]

'Harlequin Launches Red Dress Ink', The Write News: News, Features and Resources for Media and Publishing Professionals, 30 November 2001 <http://www.writenews.com/2001/113001_red_dress_ink.htm> [accessed 06 February 2008] 
Harlequin Mondadori, 'La women's fiction in Italia'< 4 ttp://www.eharmony.it/

Chi-siamo/Harmony-Italia> [accessed 1 March 2011]

Harris, Anita, ed., All About the Girl: Power, Culture, and Identity (New York:

Routledge, 2004)

Harzewski, Stephanie, 'The Limits of Defamiliarization: Sex and the City as Late

Heterosexuality', The Scholar and Feminist Online, 3 (2004)

<http://www.barnard.edu/sfonline/hbo/harzewski_01.htm>

— - 'Tradition and Displacement in the New Novel of Manners', in Chick Lit: The New Woman's Fiction, ed. by Suzanne Ferriss and Mallory Young (New York: Routledge, 2006), pp. 29-46

—, Chick Lit and Postfeminism (Charlottesville and London: University of Virginia Press, 2011)

Herald, Diana Tixier, 'Emerging Genres', in Genreflecting. A Guide to Popular Reading Interests, ed. by Wayne A. Wiegand (Westport: Libraries Unlimited, 2006), pp. 493-502

Hernanz, Virginia, and others, 'Dreaming of a Permanent Job: the Transitions of Temporary Workers in Italy and Spain', in Flexibility and Employment Security in Europe: Labour Markets in Transition, ed. by Ruud J.A. Muffels (Cheltenham; Northampton: Edward Elgar, 2008), pp. 79-106

Hesmondhalgh, David, The Cultural Industries (London: Sage, 2007)

Hollows, Joanne, 'Feeling Like a Domestic Goddess', European Journal of Cultural Studies, 6 (2003), 179 -202

Infinitestorie, 'Essere donna, leggere, scrivere... Ce ne parla Alessandra Casella', $<$ http://www.infinitestorie.it/frames.speciali/speciali.asp?ID=32> [accessed 10 June 2008].

'Intervista a Carlotta Magnanini', Delirio.Net, 31 August 2004 <http://www.delirio.net/ default.asp?id=102> [accessed 14 March 2009]

'Intervista a Virginia Fiume \# 1. Il suo libro, le donne, il lavoro e molto altro', Bizbiz, 19 December 2007 <http://thebizbiz.blogspot.com/2007/12/ intervista-virginia-fiume-1-il-suo.html > [accessed 12 January 2011] 
Jeffers McDonald, Tamar, Romantic Comedy (London: Wallflower Press, 2007)

Jensen, Margaret Ann, Love's \$weet Return: The Harlequin Story (Toronto: The Women's Press, 1984)

Johnson, Claudia L., Jane Austen: Women, Politics, and the Novel (Chicago: University of Chicago Press, 1988)

Jones, Vivien, 'Post-feminist Austen', Critical Quarterly, 52 (2010), 65-82 <doi:10.1111/j.1467-8705.2010.01949.x> [accessed 12 January 2011]

Kaler, Anne K., and Rosemary Johnson-Kurek, eds, Romantic Conventions (Bowling Green: Bowling Green State University Popular Press, 1999)

Kaplan, Ann E., Women and Film (New York, London: Methuen, 1983)

Kaplan, Cora, 'The Thorn Birds: Fiction, Fantasy, Femininity', in Formations of Fantasy, ed. by Victor Burgin, James Donald and Cora Kaplan (London and New York: Methuen, 1986), pp. 142-66

Kaplan, Deborah, Jane Austen Among Women (London and Baltimore: Johns Hoskins University Press, 1994)

Keyes, Marian, Sushi for Beginners (London: Michael Joseph; Penguin, 2000)

Kiernan, Anna, 'No Satisfaction: Sex and the City, Run Catch Kiss, and the Conflict of Desires in Chick Lit's New Heroines', in Chick Lit: The New Woman's Fiction, ed. by Suzanne Ferriss and Mallory Young (New York: Routledge, 2006), pp. $207-18$

Kinsella, Sophie, The Secret Dreamworld of a Shopaholic (London: Black Swan, 2000)

Kolesnikov-Jessop, Sonia, 'This One's For the Girls: Asians Embrace Chick Lit', Newsweek Magazine, 11 June 2009 <http://www.thedailybeast.com/newsweek/ 2009/06/11/this-one-s-for-the-girls.html> [accessed 12 October 2009] 
Knowles, Joanne, 'Material Girls: Location and Economics in Chicklit Fiction, Or, How Singletons Finance Their Jimmy Choo Collections', Diegesis, 8 (2004), $36-41$

__, "Our foes are almost as many as our readers": Debating the Worth of Women's Reading and Writing - The Case of Chick-Lit', Popular Narrative Media, 1 (2008), 217-231

Konchar Farr, Cecilia, 'It Was Chick Lit All Along', in You've Come a Long Way, Baby: Women, Politics, and Popular Culture, ed. by Lilly J. Goren (Lexington: University Press of Kentucky, 2009), pp. 201-14

La Porta, Filippo, 'Contro il nuovo giallo italiano', in Ferroni, Giulio, and others, Sul banco dei cattivi (Rome: Donizelli, 2006), pp. 55-75

Lazar, Michelle M., "'Discover the Power of Femininity!": Analyzing Global "Power Femininity" in Local Advertising', Feminist Media Studies, 6 (2006), 505-17 <doi:10.1080/14680770600990002> [accessed 27 August 2010]

Lazzari, Giovanni, Libri e popolo: politica della biblioteca pubblica in Italia dell'Unità ad oggi (Napoli: Liguori, 1985)

Lee, A. Robert, ed., China Fictions/English Language: Literary Essays in Diaspora, Memory, Story (Amsterdam, New York: Rodopi, 2008)

Lepri, Laura, 'L'amore come commedia', in Tirature 06, ed. by Vittorio Spinazzola (Milan: Gruppo editoriale il Saggiatore/Fondazione Mondadori, 2006), pp. 33-38

Lepschy, Anna Laura, 'The Popular Novel, 1850-1920', in A History of Women's Writing in Italy, ed. by Letizia Panizza and Sharon Wood (Cambridge and New York: Cambridge University Press, 2000), pp. 177-89

Liala, Signorsì (Milan: Mondadori, 1931)

Long, Elizabeth, 'Women, Reading, and Cultural Authority: Some Implications of the Audience Perspective in Cultural Studies', American Quarterly, 38 (1986), 591-612

—, Book Clubs: Women and the Uses of Reading in Everyday Life (Chicago: University of Chicago Press, 2003) 
Lotz, Amanda, 'Postfeminist Television Criticism: Rehabilitating Critical Terms and Identifying Postfeminist Attributes', Feminist Media Studies, 1 (2001), 105-21

Lucamante, Stefania, ed., Italian Pulp Fiction: The New Narrative of the Giovani Cannibali Writers (Madison: Fairleigh Dickinson University Press, 2001)

__, 'Everyday Consumerism and Pornography "Above the Pulp Line"', in Italian Pulp Fiction: The New Narrative of the Giovani Cannibali Writers, ed. by Stefania Lucamante (Madison: Fairleigh Dickinson University Press, 2001), pp. 98-134

— A Multitude of Women: The Challenges of the Contemporary Italian Novel (Toronto: University of Toronto Press, 2008)

Ludovici, Manuela Samek, and Renata Semenza, 'The Italian Case: From Employment Regulation to Welfare Reforms?', Social Policy and Administration, 42 (2008), 160-76 <doi: 10.1111/j.1467-9515.2008.00601.x> [accessed 26 June 2010]

Magnanini, Carlotta, Valentina compra tutto: Una guida allo shopping metropolitano a Rome, Parigi, Londra (Reggio Emilia: Aliberti, 2002)

Maher, Jennifer, 'The Post-Feminist Mystique', College Literature, 34 (2007), 193-201

Manera, Livia, 'Arrivano le single, regine della narrativa', Il Corriere della Sera, 13 July 2000, p. 35

Marra, Wanda, 'Harmony: E il romanzo diventa businnes', RaiLibro: Settimanale di scritture e letture (2007) <http://www.railibro.rai.it/interviste.asp?id=68>

_- 'Mille sfumature, un solo colore', RaiLibro: Settimanale di scritture e letture (2007) <http://www.railibro.rai.it/articoli.asp?id=88> [accessed 12 January 2008]

_ - 'Salani tra tradizione e innovazione', RaiLibro: Settimanale di letture e scritture (2007) <http://www.railibro.rai.it/interviste.asp?id=69> [accessed 12 January 2008]

—_, 'Stefania Bertola: scrivo per divertire', RaiLibro: Settimanale di letture e scritture, (2007) <http://www.railibro.rai.it/interviste.asp?id=66> [accessed 12 January 2008] 
Masini, Andrea, 'L'italiano contemporaneo e la lingua dei media', in La lingua italiana e i mass media, ed. by Ilaria Bonomi, Andrea Masini and Silvia Morgana (Rome: Carocci Editore, 2003), pp. 11-32

Mati, Susanna, Sex and the City: Favola della donna single (Bergamo: Moretti \& Vitali, 2011)

Matthews, Nicole, and Nickianne Moody, eds, Judging a Book By Its Cover: Fans, Publishers, Designers and the Marketing of Fiction (Aldershot and Burlington: Ashgate, 2007)

Mazza, Cris, 'Who's Laughing Now? A Short Story of Chick Lit and the Perversion of a Genre', in Chick Lit: The New Woman's Fiction, ed. by Suzanne Ferriss and Mallory Young (New York: Routledge, 2006), pp. 17-28

_ - and Jeffrey DeShell, eds, Chick Lit Postfeminist Fiction, 1st ed (Normal, Illinois: Fiction Collective 2, 1995)

Mazzocchi, Silvana, 'Monica, amori e avventure di una trentenne a New York', Repubblica, 18 December 2008, <http://www.repubblica.it/2008/12/sezioni/ spettacoli_e_cultura/passaparola-3/libri-bosco/libri-bosco.html> [accessed 20 January 2009]

McRobbie, Angela, 'Post-Feminism and Popular Culture', Feminist Media Studies, 4 (2004), 255-64

—_, 'Young Women and Consumer Culture', Cultural Studies, 22 (2008), 531-550

Membretti, Andrea, 'Centro Sociale Leoncavallo. Building Citizenship as an Innovative Service', European Urban and Regional Studies, 14 (2007), 252-63 <doi: 10.1177/0969776407077742> [accessed 22 November 2010]

Merrick, Elizabeth, This Is Not Chick Lit (New York: Random House, 2006)

Mills, Sara, 'Post-feminist Text Analysis', Language and Literature, 7 (1998), 235-52

Mizzau, Marina, 'Strategie narrative: Il non detto e il troppo detto', in Intorno al rosa, ed. by Centro di documentazione ricerca e iniziativa delle donne (Verona: Essedue, 1987), pp. 47-57 
Mlynowski, Sarah, and Farrin Jacobs, See Jane Write: A Girl's Guide to Writing Chick Lit (Philadelphia: Quirk Books, 2006)

Moccia, Federico, Tre metri sopra il cielo, (Milan: Feltrinelli, 2004)

— Ho voglia di te (Milan: Feltrinelli, 2006)

Modleski, Tania, Feminism Without Women: Culture and Criticism in a Postfeminist Age (New York: Routledge, 1991)

— Loving with a Vengeance: Mass-Produced Fantasies for Women, 2nd edition (New York: Routledge, c1982, 2008)

Mondello, Elisabetta, La nuova italiana: La donna nella stampa e nella cultura del ventennio (Rome: Editori Riuniti, 1987)

—_, La narrativa italiana degli anni Novanta (Rome: Meltemi, 2004)

—_, In principio fu Tondelli (Milan: Il Saggiatore, 2007)

Montemurro, Beth, 'Charlotte Chooses Her Choice: Liberal Feminism on Sex and the City', The Scholar and Feminist Online, 3 (2004) <http://www.barnard.edu/ sfonline/hbo/montemurro_01.htm> [accessed 8 February 2011]

Mortimer, Claire, Romantic Comedy (New York: Routledge, 2010)

Moseley, Rachel, and Jacinda Read, "Having it Ally": Popular Television (Post-)Feminism', Feminist Media Studies, 2 (2002), 231-49

Muffels, Ruud J.A., Flexibility and Employment Security in Europe: Labour markets in transition (Cheltenham; Northampton: Edward Elgar, 2008)

Murgia, Annalisa, Dalla precarietà lavorativa alla precarietà sociale: Biografie in transito tra lavoro e non lavoro (Bologna: Emil, 2010)

Nash, Walter, The Language of Humour (London, New York: Longman, 1985)

Neale, Stephen, Genre (London: British Film Institute, 1980)

—_, 'Questions of Genre', Screen, 31 (1990), 45-66 
Negra, Diane, 'Quality Postfeminism? Sex and the Single Girl on HBO', Genders, 39 (2004) <http://www.genders.org/g39/g39_negra.html> [accessed 18 March 2009]

Newton Compton, Foreign Rights Frankfurt 2009 Fiction and Non-Fiction (Rome: Newton Compton, 2009)

— C Catalogo 2009 (Rome: Newton Compton, 2009)

— Catalogo 2010 (Rome: Newton Compton, 2010)

Ommundsen, Wenche, 'From China With Love: Chick Lit and The New Crossover Fiction', in China Fictions/English Language: Literary Essays in Diaspora, Memory, Story, ed. by A. Robert Lee (Amsterdam: Rodopi, 2008), pp. 327-45

Page, Ruth, 'Bridget Jones's Diary and Feminist Narratology', in Contemporary Stylistics, ed. by Marina Lambrou and Peter Stockwell (London: Continuum, 2007), pp. 93-105

Palieri, Maria Serena, 'Il rosa e il nero: e il caffè paga il libro', L'Unità, 08 October 2004 , p. 22

Panizza, Letizia, and Sharon Wood, eds, A History of Women's Writing in Italy (Cambridge; New York: Cambridge University Press, 2000)

Patriarca, Silvana, 'Journalists and essayists, 1850-1915', in A History of Women's Writing in Italy, ed. by Letizia Panizza and Sharon Wood (Cambridge: Cambridge University Press, 2000), pp. 151-63

Pérez Serrano, Elena, 'Chick Lit and Marian Keyes: The Ideological Background of the Genre', Working Papers on the Web, 13 (2009) <http://extra.shu.ac.uk/ wpw/chicklit/perezserrano.html $>$ [accessed 15 December 2009]

Petronio, Giuseppe, Letteratura di massa. Letteratura di consumo (Rome-Bari: Laterza, 1979)

—., Critica e società di massa (Trieste: LINT, 1983)

Philips, Deborah, 'Shopping for Men: The Single Woman Narrative', Women: A Cultural Review, 11 (2000), 238-51 <doi: 10.1080/09574040010003106> [accessed 21 March 2009] 
Pickering-Iazzi, Robin, 'Novel: Romance', in The Feminist Encyclopedia of Italian Literature, ed. by Rinaldina Russell (Westport: Greenwood Press, 1997), pp. 233-35

—, Politics of the Visible: Writing Women, Culture, and Fascism (Minneapolis: University of Minnesota Press, 1997)

Pieterse, Jan Nederveen, 'Globalization as Hybridization', in Global Modernities, ed. by Mike Featherstone, Scott Lash and Roland Robertson (London: Sage, 1995), pp. $45-68$

Pischedda, Bruno, 'I sentimenti giovani di Brunella Gasperini', in Il successo letterario, ed. by Vittorio Spinazzola (Milan: Unicopli, 1985), pp. 123-45

Polese, Ranieri, 'Bye bye America, il bestseller torna in Italia', Il Corriere della Sera, 13 November 2007, p. 49 <http://archiviostorico.corriere.it/2007/novembre/13/ Bye_bye_America_bestseller_torna_co_9_071113035.shtml $>$ [accessed 2 May 2010]

Povoledo, Elisabetta, 'Women's Fiction for Europe: "No Cowboys, No Babies", The New York Times, 18 October 2004 <http://www.nytimes.com/2004/10/17/ business/ worldbusiness/17iht-books18.html?_r=1> [accessed 21 March 2009]

Pozzato, Maria Pia, Il romanzo rosa (Rome: Edizioni L’Espresso, 1982)

Probyn, Elspeth, 'Choosing Choice: Images of Sexuality and "Choiceoisie" in Popular Culture', in Negotiating at the Margins, ed. by Sue Fisher and Kathy Davis (New Brunswick: Rutgers University Press, 1993), pp. 278-94

—_, 'New Traditionalism and Post-feminism: TV Does the Home', Screen, 31 (1990), 147-59

Projansky, Sarah, Watching Rape: Film and Television in Postfeminist Culture (New York: New York University Press, 2001)

Pucci, Suzanne R., and James Thompson, eds, Jane Austen and Co.: Remaking the Past in Contemporary Culture (New York: State University of New York Press, 2003)

Pugno, Laura, 'Chick lit, (post)romantiche senza miele', Il manifesto, 28 December 2005 
Radway, Janice, Reading the Romance: Women, Patriarchy and Popular Literature (Chapel Hill: University of North Carolina Press, 1991)

Ragone, Giovanni, 'Editoria, letteratura e comunicazione', in Letteratura italiana. Storia e geografia, III, ed. by Alberto Asor Rosa (Turin: Einaudi, 1989), pp. 1047-167

Rak, Michele, Rosa: La letteratura del divertimento amoroso (Rome: Donizelli, 1999)

Rangeri, Norma, Chi l'ha vista? Tutto il peggio della TV da Berlusconi a Prodi (o viceversa) (Milan: Rizzoli, 2007)

Regis, Pamela, A Natural History of the Romance Novel (Philadelphia: University of Pennsylvania Press, 2003)

Roberts, Thomas J., An Aesthetics of Junk Fiction (Athens: University of Georgia Press, 1990)

Robertson, Roland, Globalization: Social Theory and Global Culture (London: Sage, 1992)

—_ 'Glocalization: Time-Space and Homogeneity-Heterogeneity', in Global Modernities, ed. by Mike Featherstone, Scott Lash and Roland Robertson (London: Sage, 1995), pp. 25-44

Roccella, Eugenia, La letteratura rosa (Rome: Editori Riuniti, 1998)

Romance Writers of America, 'The Romance Genre Overview' <http://www.rwa.org/cs/the_romance_genre> [accessed 3 February 2011]

Romeo, Maria Paola, 'Narrativa sostantivo femminile', Giornale della Libreria, 119 (2006), 38-43

Rosa, Giovanna, 'L'amore come romanticheria: La riscossa del rosa', in Tirature 06, ed. by Vittorio Spinazzola (Milan: Gruppo editoriale il Saggiatore/Fondazione Mondadori, 2006), pp. 10-16

__, 'Lo specchio di Liala', in Il successo letterario, ed. by Vittorio Spinazzola (Milan: Unicopli, 1985), pp. 37-69

Rose, Margaret A., Parody / Meta-Fiction (London: Croom Helm, 1979) 
Rosmarin, Adena, The Power of Genre (Minneapolis: University of Minnesota Press, 1985)

Russell, Rinaldina, ed., The Feminist Encyclopedia of Italian Literature (Westport:

Greenwood Press, 1997)

Salis, Stefano, 'Calendario editoriale: Settore solido ma non in crescita', in Tirature 08, ed. by Vittorio Spinazzola (Milan: Gruppo editoriale il

Saggiatore/Fondazione Mondadori, 2008), pp. 234-48

Sanders, Julie, Adaptation and Appropriation (New York: Routledge, 2006)

Sbisà, Annamaria, 'Generazione Rosa Shokking', La Repubblica Milano, 3 July 2007 <http://milano.repubblica.it/dettaglio/Generazione-Rosa-shokking/1334005> [accessed 18 March 2009]

Sellei, Nora, 'Bridget Jones and Hungarian Chick Lit', in Chick Lit: The New Woman's Fiction, ed. by Suzanne Ferriss and Mallory Young (New York: Routledge, 2006), pp. 173-88

Senate, Melissa, See Jane Date (Richmond: Red Dress Ink, 2001)

Sennett, Richard, The Corrosion of Character: The Personal Consequences of Work in the New Capitalism (New York; London: W. W. Norton, 1999)

Smith, Caroline J., Cosmopolitan Culture and Consumerism in Chick Lit (New York: Routledge, 2008)

Sniader Lanser, Susan, Fictions of Authority: Women Writers and Narrative Voice (Ithaca and London: Cornell University Press, 1992)

Snitow, Ann, Christine Stansell, and Sharon Thompson, eds, Desire: The Politics of Sexuality (London: Virago, 1984)

Spinazzola, Vittorio, 'Qualche ipotesi sulla narrativa "rosa". Conversazione con Brunella Gasperini', in Pubblico 1977, ed. by Vittorio Spinazzola (Milan: Il Saggiatore, 1977), 126-43

__, Il successo letterario (Milan: Unicopli, 1985) 
__ ' 'Il successo senza valore', in Il successo letterario, ed. by Vittorio Spinazzola (Milan: Unicopli, 1985), pp. 7-34

__ L'immaginazione divertente. Il giallo, il rosa, il porno, il fumetto (Milan: Rizzoli RCS, 1995)

__ L L L modernità letteraria (Milan: Net, 2005)

—_, ed., Tirature 05. Giovani scrittori e personaggi giovani (Milan: Gruppo editoriale il Saggiatore/Fondazione Mondadori, 2005)

_- Tirature 06. Di cosa parlano i romanzi d'amore? (Milan: Gruppo editoriale il Saggiatore/Fondazione Mondadori, 2006)

—, Tirature 08: L'immaginario a fumetti (Milan: Gruppo editoriale il Saggiatore/Fondazione Mondadori, 2008)

Squires, Claire, Marketing Literature: The Making of Contemporary Writing in Britain (New York: Palgrave Macmillan, 2007)

Straubhaar, Joseph D., 'Beyond Media Imperialism: Asymmetrical Interdependence and Cultural Proximity’, Critical Studies in Mass Communication, 8 (1991), $39-59$

Sughi, Laura, Evasione e conformismo nella narrativa rosa (Florence: D’Anna, 1977)

Tasker, Yvonne, and Diane Negra, eds, Interrogating Postfeminism: Gender and the Politics of Popular Culture (Durham: Duke University Press, 2007)

Teardo, Sara, 'Alla conquista della scena: Donne e scrittura negli anni Cinquanta e Sessanta' (unpublished PhD, New Brunswick: Rutgers University, 2009)

Thomas, Scarlett, 'The Great Chick Lit Conspiracy', Independent, 4 August 2002 $<$ http://www.independent.co.uk/arts-entertainment/books/features/the-great-chi ck-lit-conspiracy-638935.html> [accessed 18 March 2008]

Tomlinson, John, Cultural Imperialism: A Critical Introduction (London: Pinter Publishers, 1991)

Tommaso, Marina, Brunella Gasperini: La rivoluzione sottovoce (Reggio Emilia: Diabasis, 1999) 
Turchetta, Gianni, 'L'amore come sentimento: L'antidoto della tenerezza', in Tirature 06, ed. by Vittorio Spinazzola (Milan: Gruppo editoriale il

Saggiatore/Fondazione Mondadori, 2006), pp. 24-32

Van Slooten, Jessica Lyn, 'Fashionably Indebted: Conspicuous Consumption, Fashion and Romance in Sophie Kinsella's Shopaholic Trilogy', in Chick Lit: The New Woman's Fiction, ed. by Suzanne Ferris and Mallory Young (New York:

Routledge, 2006), pp. 219-38

Vidmar-Horvat, Ksenija, 'The Globalization of Gender: Ally McBeal in Post-socialist Slovenia', European Journal of Cultural Studies, 8 (2005), 239-55

Vigini, Giuliano, 'Single', Il Corriere della Sera, 17 March 2002, p. 28

Vittorini, Camilla, Qualcosa bolle in città (Milan: Red Dress Ink, 2004)

Vitulli, Stefania, 'Storie femminili di shopping, di sesso e di città', Il Giornale, 20 July $2008<$ http://www.ilgiornale.it/cultura/storie_femminili_shopping_sesso_e_ citta/20-07-2008/articolo-id $=277354$-page $=0$-comments $=1>$ [accessed 10 September 2008]

Viviani, Aglaia, 'Eroine del nuovo millennio', Leggendaria, 43 (2004) <http://www.libreriadelledonne.it/Stanze/Paradiso/Nespole/Leggendaria2.htm> [accessed 15 January 2008]

Vnuk, Rebecca, 'Hip Lit for Hip Chicks', Library Journal, 130 (2005), 42-45

Weinberg, Anna, 'She's Come Undone: Chick Lit Was Supposed to Be the Bright Light of Postfeminist Writing. What Happened?' Book, July-August 2003, pp. 47-49

Weiner, Jennifer, In Her Shoes (New York: Atria Books, 2002)

Weisberger, Lauren, The Devil Wears Prada (New York: Doubleday, 2003)

Wells, Juliette, 'Mothers of Chick Lit? Women Writers, Readers and Literary History', in Chick Lit: The New Woman's Fiction, ed. by Suzanne Ferriss and Mallory Young (New York: Routledge, 2006), pp. 47-70 
Whelehan, Imelda, Overloaded: Popular Culture and the Future of Feminism (London: The Women's Press, 2000)

— - Helen Fielding's Bridget Jones's Diary: A Reader's Guide (New York:

Continuum, 2002)

—, The Feminist Bestseller: From Sex and the Single Girl to Sex and the City (New York: Palgrave Macmillan, 2005)

— - 'Teening Chick Lit?', Working Papers on the Web, 13 (2009) $<$ http://extra.shu.ac.uk/wpw/chicklit/whehelan.html> [accessed 15 December 2009]

—_, 'Remaking Feminism: Or Why Is Postfeminism So Boring?', Nordic Journal of English Studies, 9 (2010), 155-172

Wolf, Naomi, Fire with Fire: The New Female Power and How It Will Change the 21st Century, (New York: Random House, 1993)

Women's Fiction Festival, 'Alessandra Bazardi', <http://www.womensfictionfestival.com/cms/content/view/78/113/lang,en/> [accessed 9 March 2011]

—_, 'Camilla Vittorini', <http://www.womensfictionfestival.com/cms/content/view/ 76/113/lang, it/> [accessed 9 March 2011]

Wood, Sharon, Italian Women's Writing 1860-1994 (London: The Athlone Press, 1995)

Zanardo, Lorella, Il corpo delle donne (Milan: Feltrinelli, 2010)

Zaslow, Emilie, Feminism, Inc. Coming of Age in Girl Power Media Culture (New York: Palgrave Macmillan, 2009)

Zunino, Pier Giorgio, L'ideologia del fascismo: Miti, credenze e valori nella stabilizzazione del regime (Bologna: Il Mulino, 1985) 